$$
\text { Universidade de São Paulo }
$$

Faculdade de Filosofia Letras e Ciências Humanas

Departamento de Geografia

Programa de Pós-Graduação em Geografia Humana

\title{
Estado, Espaço e Acumulação na crise contemporânea
}

Murilo Medici Navarro da Cruz 


\title{
Universidade de São Paulo \\ Faculdade de Filosofia Letras e Ciências Humanas \\ Departamento de Geografia \\ Programa de Pós-Graduação em Geografia Humana
}

Estado, Espaço e Acumulação na crise contemporânea

\author{
Murilo Medici Navarro da Cruz
}

Dissertação apresentada ao Departamento de Geografia da Faculdade de Filosofia, Letras e Ciências Humanas, Universidade de São Paulo, como parte dos requisitos

para obtenção do grau de mestre em

Geografia Humana.

Orientadora: Profa. Dra. Ana Fani Alessandri Carlos 
Às minhas meninas;

e a todos aqueles que, como nós, desejam uma sociedade mais unitária. 


\section{Agradecimentos}

A realização deste trabalho seria absolutamente impossível sem a presença constante ao meu lado da Fabiana, minha mulher. Sua colaboração não foi apenas como companheira, o que ela já faz tremendamente bem. Foi também de interlocutora fiel, apontando incansavelmente os limites de meu pensamento que constantemente tende a estruturalismos e generalizações abstratas.

Igualmente importante em termos de debate de idéias foi a relação que mantenho desde os anos da graduação com dois amigos, que de início eram colegas de curso: César, o Companheiro, e Sérgio, o Sessé. Juntos fizemos os primeiros trabalhos e grupos de estudo, até hoje se mantém um debate incansável em torno de questões teóricas, políticas e para além delas. Muitas, mas muitas mesmo, das idéias aqui expostas pertencem também a ambos.

Fani, minha paciente e compreensiva orientadora, se manteve como um exemplo de resistência - política e intelectual - contra o processo que tenta solapar as bases de uma universidade pública autônoma e que preze pela produção do conhecimento. Sua maior lição desde a época da orientação nos programas de iniciação científica sempre foi sobre o respeito ao tempo do conhecimento. Mas durante o processo do mestrado, suas colaborações - seja nas aulas, seja nos colóquios do Labur - acerca da compreensão da obra de Henri Lefebvre foram altamente esclarecedoras.

Aos colegas do Labur também não posso deixar de me referir, tanto nas discussões sobre os textos de Marx como de Lefebvre, o convívio, mesmo que raro em algumas fases, teve oportunidades enriquecedoras.

Da mesma forma o foram as conversas estabelecidas por noites e noites com a amiga Érica. Historiadora, persistente em suas posições, muitas vezes diferentes das minhas, mas que justamente por isso sempre apareceram como desafios.

Aos colegas de trabalho do Colégio Poliedro agradeço, para alguns, pela manutenção do debate e da troca de idéias, para outros, pela compreensão em relação às situações conturbadas pelas quais passa muitas vezes o pesquisador brasileiro. Mas ainda dentro desta instituição, agradeço, principalmente aos meus alunos, que nestes últimos anos vêm me ouvindo falar sobre temas que, muitas vezes, levaram a idéias que se materializaram diretamente neste trabalho. 
À minha filha Luísa eu agradeço o carinho com o qual muitas vezes compreendeu minha ausência nos momentos em que se fazia tão importante uma brincadeira ou a leitura de uma história. À Helena, ainda tão nova, é importante dizer que só presenciou estes meses de trabalho por ter nascido pouco antes do tempo esperado e me levado assim a pedir uma prorrogação de prazo. Aos meus pais e meus irmãos eu agradeço a compreensão pelas minhas constantes ausências nos almoços de domingo - nos quais as conversas com meu pai acerca das manchetes dos jornais sempre renderam ótimas reflexões que por certo se fazem presentes nestas páginas. No mesmo sentido devo me referir aos amigos que me viram pouco nos últimos meses em que me concentrei na elaboração desta dissertação.

À CAPES agradeço pelo apoio financeiro por meio de bolsa de mestrado durante o ano de 2005. 


\section{Resumo}

Este trabalho parte de uma questão posta pela realidade atual: a crise econômica mundial, percebida principalmente no que vem se denominando de financeirização da economia e, conjuntamente a esta crise, aquela do Estado nacional, ambas vistas na perspetiva mundial e, igualmente, na brasileira. Não há, no entanto, o objetivo aqui de se fazer um tratamento histórico ou puramente econômico do problema. Ao invés disso, o que se verá está mais próximo de um exercício teórico e analítico. Este se constitui, em primeiro lugar, de uma discussão aprofundada sobre os fundamentos da economia capitalista que, segundo se entende, são também os fundamentos da crise econômica atual. Em segundo lugar, para se refletir tanto sobre a crise econômica como sobre a política fazse uma reflexão sobre a produção do espaço e o papel do Estado no conjunto da sociedade capitalista. Em terceiro lugar, a conjunção entre o Estado e o capital se mostra identificável na análise do território nacional e seus fundamentos. Por último, o problema da crise atual é posto por meio de uma crítica à idéia de desterritorialização, crítica esta que leva à formulação da hipótese de uma territorialização abstrata, que seria característica da própria crise.

\section{Abstract}

This work starts from a matter put by the current reality: The world economic crisis, specially seem on what has been denominated "money predomination economy" and, along with the crisis, the one of national State, both seen under the world's perspective and, equally, the Brazilian perspective. Nevertheless, this work does not intend, herein, to give a historical or purely economic treatment of the problem. Instead, what you will see is closer to an analytical and theoretical exercise. This work constitutes, firstly, of a deep discussion about the basis of capital economy which, according to what is understood, also are the basis of the current economic crisis. Secondly, to reflect about the economic crisis as much as politics, is necessary to reflect about the production of space and the State's role within the capitalist society. And thirdly, the union between the State and the capital shows itself identifiable on the national territory analysis along with your basis. Last but not least, the current crisis problem is put through a criticism to the lack of focusing the capital on a specific market, criticism that takes us to formulate the hypothesis of an abstract investment of capital, which would be a characteristic of the crisis itself. 


\section{Palavras-chave}

Espaço, Capital, Estado, Acumulação, Crise

\section{Key Words}

Space, Capital, State, Accumulation, Crisis. 


\section{Índice}

Introdução 10

Esclarecimento conceitual: sobre as separações 12

1 - A separação como origem (ou fundamento) do capitalismo. 23

Primeiro Excurso sobre encontros e desencontros metodológicos 35

2 - O capital como movimento: separação, crítica e crise. 40

3 - O capital como movimento: a separação e a abstração da riqueza 48

3.1 - A produção de mais-valia como produção de riqueza abstrata 58

3.2 - Reprodução ampliada: acumulação de riqueza abstrata. 68

3.3 - O lucro como riqueza abstrata. 73

3.4 - Separação, efetivação da crise e o capital como movimento. 80

3.5 - A separação como alienação 90

Segundo Excurso sobre encontros e desencontros metodológicos 105

4-A separação além (ou aquém) da riqueza abstrata: a reprodução. 109

4.1 - O Estado e a acumulação 123

4.2 - O espaço e a acumulação 134

5 - Estado, espaço e acumulação 148

5.1 - Estado e capital em meio à problemática espacial: a dupla crise 148

5.2 - Território e territorialização 154

5.3 - A ante-sala da crise 166

5.4 - Crise e financeirização. 174

5.5 - Abertura financeira, nova estrutura financeira global e territorialização abstrata. 181

Considerações finais 188 
Dificílimo acto é o de escrever, responsabilidade das maiores, basta pensar no extenuante trabalho que será dispor por ordem temporal os acontecimentos, primeiro este, depois aquele, ou, se tal mais convém às necessidades do efeito, o sucesso de hoje posto antes do episódio de ontem, e outras não menos arriscadas acrobacias, $o$ passado como se tivesse sido agora, o presente como um contínuo sem presente nem fim, mas por muito que se esforcem os autores, uma habilidade não podem cometer, pôr por escrito, no mesmo tempo, dois casos no mesmo tempo acontecidos. Há quem julgue que a dificuldade fica resolvida dividindo a página em duas colunas, mas o ardil é ingênuo, porque primeiro se escreve uma e só depois a outra, sem se esquecer que o leitor terá de ler primeiro esta depois aquela, ou vice-versa, quem estão bem são os cantores de ópera, cada um com a sua parte nos concertantes, três quatro cinco seis entre tenores baixos sopranos e barítonos, todos a cantar palavras diferentes, por exemplo, o cínico escarnecendo, a ingênua suplicando, o galã tardo em acudir, ao espectador o que lhe interessa é a música, já o leitor não é assim, quer tudo explicado, sílaba por sílaba e uma após a outra, como aqui se mostram. Por isso é que tendo-se falado primeiro de Joaquim Sassa, só agora se irá falar de Pedro Orce, quando lançar Joaquim uma pedra ao mar e levantar-se Pedro da cadeira foi tudo obra de um instante único, ainda que pelos relógios houvesse uma hora de diferença, é o resultado de estar este em Espanha e aquele em Portugal. 


\section{Introdução}

É preciso começar esclarecendo a natureza do trabalho que se apresenta ao leitor. Partindo de uma problemática concreta, mas ao mesmo tempo muito imerso num processo de formação teórica, acabei por realizar um percurso que mais pode ser definido como um exercício teórico e analítico promovido por meio do debate com as obras de uma série de autores, do que propriamente como uma pesquisa no sentido mais comum do termo.

A problemática que sustentou minhas inquietações desde a escolha da bibliografia até a elaboração das últimas linhas dessa dissertação envolve dois movimentos. O primeiro é o que se costuma chamar de re-inserção da economia brasileira na economia mundial, promovida ao longo da década de 1990. O segundo se refere às mudanças que pude observar ao longo da minha passagem da adolescência à vida adulta (portanto nos últimos 20 anos) nas formas de socialização dos habitantes deste país. Estas mudanças parecem em geral se referirem a uma extraordinária valorização do âmbito privado em detrimento do público, verificável desde a explosão dos condomínios fechados e das empresas de segurança até a importância desmedida dada ao corpo e à aparência pessoal, passando, principalmente, pelas transformações na forma de se fazer política e na determinação das expectativas acerca do que deve ser a vida.

O processo de formação teórica no qual estava, e continuo, imerso se refere a uma constante busca pelo desenvolvimento de um ponto de vista crítico em relação à realidade que se apresenta a nós de forma dura e naturalizada. Neste sentido, venho me empenhando na leitura das obras de Marx e de Henri Lefebvre, dentre outros. Com relação ao primeiro, vejo-o com fundamental para tratar de um aspecto da realidade que é a sua redução ao âmbito da economia. Não a redução promovida pelo autor, como muitos acham, mas aquela promovida pelo próprio movimento da realidade. Em relação a Lefebvre, sua colaboração vem se dando no sentido de desvendar como aquela redução apontada por Marx se põe por outros meios que não o econômico, mais especificamente, pela produção do espaço, pela vida cotidiana e pelo Estado.

A consideração da citada problemática por meio deste processo de formação teórica me levou à formulação de algumas hipóteses. Entre elas a de que a dita re-inserção da economia brasileira na economia mundial se deu em meio à crise da economia capitalista $\mathrm{e}$ 
do Estado nacional, uma crise dupla com múltiplas conseqüências. Mas esta crise não foi entendida como alguma forma de declínio do capital, ao contrário, o foi como sua reafirmação. Como consequiência e continuidade desta primeira hipótese pode-se destacar também a de que o que temos visto em meio a esta crise é um processo de territorialização abstrata que para alguns aparece como desterritorialização. O objetivo principal em relação a estas duas hipóteses não é promover sua comprovação por meio de algum método estatístico ou qualquer outra forma de trabalho empírico - o que não significa que tais tentativas não tenham a sua importância. Ao invés disso, a opção aqui assumida foi a de utilizar o arcabouço conceitual apreendido naquele processo de formação referido para com ele tentar explorar as tais hipóteses.

A seguir, antes ainda do primeiro capítulo, se encontrará uma primeira tentativa de esclarecimento acercada da noção de separação que acabou servindo como fio condutor das reflexões até o final do trabalho.

Os capítulos 1, 2 e 3, se referem a um esforço por compreender alguns aspectos da obra de Marx e de alguns marxistas. Deve-se saber desde já que este exercício tem o sentido de preparar o que virá a seguir - apesar de não se limitar de maneira nenhuma a alguma forma de parte metodológica, como se poderia imaginar num erro de avaliação. Mas para deixar claro, desde já, o sentido destas reflexões se liga à necessidade de se entender o processo de abstração da riqueza claramente identificável, por exemplo, no que vem se chamando de financeirização.

Entre os capítulos 1 e 2, um Primeiro Excurso chama a atenção para a natureza das reflexões teóricas feitas nos capítulos 2 e 3. Por sua vez, após este último, um Segundo Excurso fala da tentativa de se ir além da discussão teórica daqueles capítulos, mesmo que a conservando como pressuposto.

No capítulo 4, o espaço e o Estado são discutidos como âmbitos envolvidos em processos não econômicos de acumulação. É justamente aí que se encontra uma tentativa de esclarecer os conceitos importantes de acumulação primitiva, originária e estatista.

Finalmente, no capítulo 5, Estado, espaço e acumulação são vistos de forma integrada por meio da escala do território nacional, o qual acaba sendo o centro da discussão sobre a crise atual e sobre a territorialização abstrata. 


\section{Esclarecimento conceitual: sobre as separações}

A idéia de separação entendida como um processo por meio do qual são estabelecidos limites ou barreiras sociais ou mentais pode ser encontrada em conceitos como os de alienação, abstração, crise ou em termos mais comuns e gerais como os de alheamento, privação, expropriação, apartamento, divisão. Ou, ainda, na apresentação de elementos fundamentais da estrutura teórica marxiana sobre a sociedade capitalista, como os de fetichismo, valor, dinheiro, mais-valia, reprodução ampliada e acumulação primitiva, dentre tantos outros.

Esta mesma idéia é de fundamental importância para o entendimento do Estado. O Estado como abstração concreta é produto e condição de uma ampla cadeia de abstrações sociais e mentais, isto é, de separações. Ao mesmo tempo, a dimensão territorial do Estado, sem a qual ele não existe, também pode ser, em grande parte, discutida tendo por base a idéia de separação. Mas para além da simples dimensão territorial do Estado, o âmbito espacial da vida social, ou melhor, o espaço socialmente produzido é caracterizado por um movimento de eliminação das separações próprias do espaço natural (a distância absoluta) que foi sendo solapado por novas formas de separação no espaço produzido, destacando-se a propriedade privada e os limites políticos.

Parto, portanto, da separação como uma noção que nos permite estabelecer uma compreensão sobre aspectos do capital, do Estado e do espaço ${ }^{1}$, aspectos estes principalmente ligados à problemática do poder e da reprodução das relações sociais de produção. É neste sentido que esta mesma noção aparece, de formas diferentes, em alguns autores de grande importância para o presente trabalho. Em seu livro A Sociedade do Espetáculo, Guy Debord afirma que "a separação é o alfa e o ômega do espetáculo" ou, ainda, que "a origem do espetáculo é a perda da unidade do mundo"2. E para além destes trechos nos quais a questão fica bastante explícita (sem falar no próprio título do primeiro capítulo - "A separação consumada...") o autor tem na idéia de separação (que muitas vezes aparece como divisão ou como abstração) o ponto fundamental de sua análise sobre a sociedade espetacular.

\footnotetext{
${ }^{1} \mathrm{O}$ espaço será entendido como espaço social, relação de mútua determinação entre práticas e representações sociais ligadas à dimensão espacial exterior na qual a existência se dá.

${ }^{2}$ Debord (1997) pág. 21 e 23.
} 
Da mesma forma, a análise feita por John Holloway em seu livro Mudar o Mundo Sem Tomar o Poder sobre as relações de poder no âmbito do capital e no do Estado é impensável sem esta mesma idéia. A separação do fluxo do fazer coletivo como forma de estabelecer o que ele define como poder-sobre (o poder de uns sobre o fazer de outros) é algo que perpassa a totalidade da obra e pode ser verificado de forma bastante clara no trecho a seguir;

Enquanto o poder-fazer é um processo de unir, o unir do meu fazer com o fazer dos outros, o exercício do poder-sobre é a separação. $O$ exercício do poder-sobre separa a concepção da execução, o feito do fazer, o fazer de uma pessoa do de outra, o sujeito do objeto. Aqueles que exercem o poder-sobre são separadores que separam o fato em relação ao fazer e os fazedores em relação aos meios de fazer ${ }^{3}$.

Em seu clássico A Grande Transformação, Karl Polanyi ataca o "moinho satânico" da economia de mercado demonstrando a tendência de autodestruição do tecido social implícita na transformação do trabalho, da terra e do dinheiro em mercadorias, o que se dá por meio de separações, como se pode verificar nos trechos a seguir;

Separar o trabalho das outras atividades da vida e sujeitá-lo às leis do mercado foi o mesmo que eliminar todas as formas orgânicas da existência e substituí-las por um tipo diferente de organização, uma organização atomista e individualista ${ }^{4}$.

Aquilo que chamamos terra é um elemento da natureza inexplicavelmente entrelaçado com as instituições do homem. Isolá-la e com ela forma um mercado foi talvez o empreendimento mais fantástico dos nossos ancestrais. [...] Imaginar a vida do homem sem a terra é o mesmo que imaginá-lo nascendo sem mãos e pés. E no entanto, separar a terra do homem e organizar a sociedade de forma a satisfazer as exigências de um mercado imobiliário foi parte vital do conceito utópico de uma economia de mercado 5 .

Para Ellen Wood, a origem do capitalismo (e o seu fundamento) está diretamente ligada a processos de separação. Separação entre o produtor e os meios de produção.

\footnotetext{
${ }^{3}$ Holloway (2003) pág. 51.

${ }^{4}$ Polanyi, 2000, pág. 198.

${ }^{5}$ Polanyi, 2000, pág. 214.
} 
Separação entre o político e o econômico ${ }^{6}$. Para Massimo de Angelis a separação é o segredo da acumulação (primitiva) e o fundamento da teoria marxista da reificação ${ }^{7}$. A separação vista como abstração ou como fragmentação está presente em inúmeras argumentações de Henri Lefebvre seja ao tratar da sociedade urbana, do Estado ou do espaço. Desta mesma maneira a noção de separação aparece em diversos outros autores que serão aqui analisados.

Dada esta constante presença da noção de separação, assim como seu caráter, a meu ver, esclarecedor para os objetivos do presente trabalho, ela deverá funcionar como um guia teórico, em torno do qual várias discussões - algumas mais teóricas outras mais analíticas - serão realizadas. Assim sendo, faz-se necessário um breve esclarecimento sobre como esta noção será entendida ao longo deste trabalho.

Para começar, se estamos falando de separações, já me parece indispensável uma reflexão sobre a separação entre os domínios do capital, do Estado e do espaço que foi apontada acima. São comuns os estudos, principalmente marxistas, que buscaram (e continuam a buscar) uma determinação da lógica do capital sobre os outros âmbitos sociais. Procurar entender a lógica do capital como uma determinação em nada atrapalha a compreensão das relações sociais, mas tentar entendê-la como a única determinação é, sem dúvida, uma opção equivocada. $\mathrm{O}$ entendimento do capital enquanto sujeito tem seu sentido. No entanto, este sentido, como se verá, é muito mais complicado de apreender do que em geral se imagina. E, o que é mais importante, mesmo que consideremos o capital como sujeito, ao fazermos esta consideração de forma rigorosa de acordo com a dialética materialista, o percebemos como um sujeito de natureza contraditória, um sujeito que, na formulação de Grespan, "ao refletir sobre si se institui e se dissolve".

Neste sentido, considerar o capital como sujeito não significa reconhecê-lo como a única determinação das relações sociais. Significa, ao contrário reconhecer os seus próprios limites como determinação de tais relações e, com isso, a necessidade de considerar suas relações com outros âmbitos. No caso deste trabalho esses outros âmbitos são, justamente, o Estado e o espaço e as relações de ambos com o capital são mais de mútua determinação do que de subsunção. Mesmo assim, por enquanto, é preciso esclarecer como as separações apareceram em cada um deles.

\footnotetext{
${ }^{6}$ Cf. A Origem do Capitalismo e Democracia contra Capitalismo.

${ }^{7} \mathrm{Cf}$. Marx and primitive accumulation: the continuous character of capital's "enclosures"

${ }^{8}$ Grespan, 1998, pág. 283.
} 
Na discussão acerca do capital as separações estão por toda parte, seja na obra de Marx, seja na de alguns marxistas aqui considerados ${ }^{9}$. A complexidade é grande e torna difícil a tarefa de escolher por onde começar e, depois de começado, qual caminho seguir entre os tantos possíveis. Para o que virá, me parece importante destacar duas formas importantes de separação que aparecem na obra de Marx, a separação do capital e a separação de $O$ Capital.

Marx inicia $O$ Capital, com a análise da mercadoria que é apresentada como "a forma elementar" da riqueza nas sociedades "em que domina o modo de produção capitalista" $"$. No entanto, os conceitos de trabalho assalariado, mais-valia e capital demoram a aparecer, ficando fora de toda a seção I do livro. Esta ausência se deve a um alto grau de abstração característico desta fase da apresentação categorial. Não é por acaso que surgiram interpretações na tradição marxista que põe em dúvida se a sociedade descrita por Marx neste trecho é realmente capitalista.

Mas o importante, por enquanto, é chamar a atenção para três idéias presentes no parágrafo anterior. Em primeiro lugar, a caracterização, feita por Marx, da mercadoria como a forma elementar da riqueza na sociedade capitalista. Em segundo lugar, a idéia de que na seção I do livro Marx realiza uma análise desta forma elementar. Em terceiro lugar, a afirmação de que a ausência dos conceitos de trabalho assalariado, mais-valia e capital se justifica pelo alto grau de abstração característico desta fase da apresentação. Não por acaso, forma elementar, análise e abstração são termos ligados à noção de separação.

O alto grau de abstração da seção I se deve, justamente, ao fato de Marx desconsiderar ali grande parte do que é a sociedade capitalista. A abstração, neste caso, tem o sentido de uma simplificação, de uma operação mental que consiste em separar um

\footnotetext{
${ }^{9}$ No capítulo 4 de seu livro Marx: Lógica e Política I, Ruy Fausto trabalha com as idéias de Benetti e Cartelier entre as quais está a de que o vínculo fundamental na sociedade capitalista é a separação. No entanto, Fausto não se debruça sobre tal idéia, mantendo-a em segundo plano. Como infelizmente não tive acesso ao texto de Benetti e Cartelier citado por Fausto (Marchands, Salariat et Capitalistes), não posso esclarecer de forma absoluta as aproximações ou diferenciações entre as minhas hipóteses aqui expostas e as destes autores. No entanto, parece haver uma certa correspondência se levarmos em conta as notas 91 e 92 do texto de Fausto, citando trechos daqueles autores, sendo respectivamente, as seguintes "a sociedade é dada e a ligação entre seus elementos é a separação, cuja expressão é a unidade de conta comum"; "o modo de existência da separação é a ruptura entre o privado e o social". Mas é preciso destacar que minha opção por utilizar o termo "separação" não decorreu destas notas, mas sim de uma percepção mais geral de sua importância para se pensar o capital, o espaço e o Estado, como explicado nos esclarecimentos conceituais precedentes.

${ }^{10}$ MARX, Karl. O Capital. São Paulo: Nova Cultural, 1988.
} 
elemento do todo e, num primeiro momento, desconsiderar a existência deste todo. Segundo Grespan ${ }^{11}$, o objetivo de Marx ao realizar esta abstração é iniciar sua obra com aquilo que está explícito no subtítulo de $O$ Capital, isto é, com uma crítica da economia política.

Partindo dos pressupostos dos economistas políticos - o que no caso significa basicamente deixar de lado a divisão de classes e, com isso, a mais-valia e o trabalho assalariado - Marx chega a conclusões bem diferentes das de seus antecessores, particularmente, na demonstração de que nesta forma elementar da riqueza capitalista já estão pressupostas as suas contradições, destacando-se a necessidade de produzir valoresde-uso (riqueza material) para promover a valorização, isto é, a produção do valor (riqueza abstrata). A forma elementar, portanto, põe-se como uma espécie de resumo do que há na estrutura geral da sociedade capitalista. Mesmo separado do todo, este pedaço contém as determinações fundamentais deste modo de produção.

Mas então há um problema a se discutir. Se na seção I, na qual se analisa a mercadoria e seu desdobramento até o dinheiro, tivéssemos um resumo da sociedade capitalista e com isso, o que é o mais importante, já estariam pressupostas as contradições deste modo de produção, como explicar a ausência do trabalho assalariado, da mais-valia e do capital? Neste caso o alto grau de abstração não seria alto demais a ponto de deixar de lado elementos sem os quais se torna impossível visualizar as contradições do capital? A resposta está, justamente, em se entender o que significa dizer que há um alto grau de abstração próprio desta fase da apresentação ${ }^{12}$, o que nos remete à idéia de que existem outras fases da apresentação e que se pressupõe que o alto grau de abstração deste início se deve ao sentido do projeto de apresentação posteriormente cumprido.

Só se pode entender a seção I ao considerá-la como parte integrante da obra, já que nela Marx expõe algo que posteriormente será negado. A função deste início não é descrever aquilo que é a sociedade capitalista, mas justamente aquilo que ela parece, mas não é, isto é, após a leitura da seção I e após remeter a interpretação feita sobre ela à leitura do restante da obra o que se extrai é que ali está exposta uma aparência negada ${ }^{13}$. Ao desconsiderar o restante da obra fica-se só com a aparência e pode-se entender que a sociedade descrita ali não é capitalista. Ao se desconsiderar este início, pondo-o como um

\footnotetext{
${ }^{11}$ Cf. Grespan, 1998, p.50.

${ }^{12}$ Cf. Rosdolsky, 2001, p. 39 a 41.

${ }^{13}$ Fausto, 1987.
} 
equívoco, como um desvio, perde-se a noção do que é negado no capitalismo e isso, como veremos, pode nos fazer deixar de apreender elementos importantes para o entendimento do capital e, principalmente do processo de alienação que o caracteriza (não custa lembrar que é justamente na seção I que Marx descreve o fetichismo da mercadoria).

Mas a atenção ao projeto de apresentação não deve se voltar apenas sobre a relação entre a seção I e o restante do livro. Ao contrário, ao longo dos três volumes é preciso sempre se atentar para o fato de que Marx está fazendo um percurso do abstrato ao concreto. A não atenção a isso pode nos levar, por exemplo, a absolutizar alguma passagem e, desta forma deixar de compreender seu significado concreto, o qual só pode ser apreendido ao final da leitura.

No restante do livro 1, Marx expõe os elementos que vão dando concretude ao processo de produção do capital, que é o foco da análise. Mas a busca pela reconstituição da totalidade concreta não é um caminho retilíneo e unitário. Ao longo do percurso apresentam-se encruzilhadas e torna-se inevitável a escolha por um ou por outro caminho. Para se preocupar, durante todo o livro 1, com a produção do capital, Marx teve de dar pouca atenção ao processo de circulação do capital, ao qual se dedica no livro 2. Enquanto no primeiro livro são os problemas da produção que parecem determinar a circulação, no segundo se dá o inverso. O ganho de concretude com esse método de exposição é impressionante, embora nem sempre de fácil compreensão.

Não é possível representar ambas as esferas ao mesmo tempo, porém falar da produção sem levar em conta as questões postas pela circulação ou vive-versa é não falar de uma nem de outra, uma vez que isoladas ambas as esferas não existem. Como é preciso se falar antes de uma e depois de outra, é preciso aproveitar a oportunidade para entender os problemas postos por cada uma para posteriormente enxergar a outra levando-os em consideração.

No livro 3, a busca é por entender o processo global da produção capitalista, o qual deveria envolver as múltiplas determinações entre a produção e a circulação do capital. Como se sabe os livros 2 e 3 foram publicados postumamente por Engels, com o agravante de que o último ainda possuía muitas partes que se resumiam a apontamentos. Mesmo assim, tais apontamentos nos ajudam a entender muito da lógica do capital, que é o 
que nos permite afirmar que os três volumes formam uma obra na qual o autor busca uma apresentação que vai das formas mais abstratas às mais concretas ${ }^{14}$.

É neste caminhar do abstrato ao concreto que se mostram as separações próprias de O Capital. Mas para realizar estas separações Marx promove um procedimento analítico. $\mathrm{O}$ procedimento analítico consiste em dividir mentalmente algo que é em si uma unidade como forma de simplificar seu entendimento e, posteriormente, refazer a unificação para ter uma compreensão melhor do todo. As discussões epistemológicas que concordassem com este procedimento definiriam-no como um método correto para se analisar qualquer conjunto complexo, sendo este o corpo humano ou a sociedade capitalista. O procedimento analítico, neste sentido, é uma divisão subjetiva da realidade, posto que é realizada pelo sujeito - que é pressuposto - sobre um objeto qualquer.

No entanto, Marx não pretende proceder conforme os cânones da epistemologia moderna. O que ele pretende é apreender uma divisão objetiva, isto é, própria do objeto. Neste caso a relação entre sujeito e objeto é diferente. O sujeito não é universal e nem absoluto. Ele é o sujeito que existe no capitalismo. Quanto ao objeto, este também é específico, ou seja, é o próprio capital e não qualquer objeto. Portanto, ao realizar a separação entre o valor de uso e valor da mercadoria, Marx demonstra que a própria mercadoria é caracterizada por esta separação. A mercadoria como uma forma social apresenta uma cisão interna entre a riqueza material e a riqueza abstrata e essa cisão constitui uma contradição, como veremos de forma mais detalhada.

É neste sentido que se a apresentação procura cumprir esse percurso que vai do abstrato ao concreto, é porque a totalidade "original" foi partida, foi quebrada, suas partes foram separadas e, com isso, ela passou por um processo de abstração. Este processo de abstração não se limita ao procedimento analítico empreendido por Marx, na verdade ele o precede.

Por isso, as separações propostas por Marx para a identificação das partes do modo de produção capitalista, não são uma tentativa de realizar uma divisão subjetiva qualquer como se fosse para falar de um pedaço de cada vez apenas para facilitar a exposição. São, isso sim, uma busca por identificar as separações objetivas promovidas pelo próprio

\footnotetext{
${ }^{14}$ Com a ressalva de que esse movimento de concreção não é crescente e retilíneo. Muitas vezes só se consegue um ganho de concreção saltando-se de um ponto para outro e mesmo voltando capítulos. Mesmo assim a estrutura da apresentação pode ser vista como tendo este sentido geral, qual seja, o de possibilitar uma reconstituição da totalidade concreta da sociedade capitalista.
} 
movimento do capital. Se por um lado, o autor dividiu o processo global de produção capitalista para apresentar uma parte dele (a produção) no livro 1 e outra (a circulação) no livro 2, para só no terceiro livro colocar ambas em choque, por outro lado, deve-se perceber que esta divisão não é arbitrária. Ao refletir separadamente sobre a produção e a circulação, Marx, deixa claro que ambas são separadas não apenas em sua obra, mas igualmente na realidade.

Se na estrutura geral da obra há este duplo aspecto (mental e real) da abstração, nos diversos momentos da apresentação categorial ele não deixa de estar presente e de ser igualmente fundamental. Fora os casos apontados acima, poder-se-ia falar de muitos outros. O próprio capital é divido entre capital constante e capital variável e tal separação é fundamental para a compreensão de pontos importantes na estrutura da obra como a diferenciação entre mais-valia absoluta e relativa e a discussão sobre a queda tendencial da taxa de lucro. Da mesma forma a separação entre os setores 1 (bens de produção) e 2 (bens de consumo) constitui o fundamento das questões postas por Marx sobre os modelos de reprodução e as crises de desproporção intersetorial.

Em todos estes casos a separação própria do capital pode ser entendida como sua cisão interna. É a separação entre a produção e a realização da riqueza. Neste sentido o valor é uma riqueza abstrata, posto que nem tudo aquilo que é produzido em termos materiais, segundo a lógica da reprodução do capital, se transforma imediatamente em riqueza. Há uma intermediação entre o momento da produção e o da realização. Esta intermediação é, justamente, a relação de troca propriamente capitalista. Propriamente capitalista porque é uma forma de troca que impõe a valorização como necessidade. E é por isso que a separação própria do capital está diretamente ligada ao processo de alienação.

Mas há ainda um outro sentido de separação diretamente ligado ao capital apesar de aparentemente externo a ele. É a separação ligada aos processos de acumulação primitiva. O conceito de acumulação primitiva, como se verá, não se limita às análises sobre os primórdios do capitalismo. Se as relações capitalistas de produção pressupõem a acumulação primitiva, ela não se limita aos primórdios do capitalismo por dois motivos. Em primeiro lugar, porque as relações capitalistas se expandem constantemente, seja no espaço, seja em diferentes âmbitos das relações sociais a priori fora do seu alcance. Em segundo lugar, porque posto que o capitalismo é contraditório não é possível entender que 
sua reprodução se dá de forma automática, ou como chama nossa atenção Holloway, "o capital nunca 'é', sua existência nunca é uma existência de duração, sempre depende da luta para se reconstituir. A reconstituição nunca pode ser presumida"15. Assim sendo, as relações capitalistas dependem constantemente de que existam relações de poder nãocapitalistas e é justamente neste sentido que serão considerados aqui os âmbitos do Estado e do espaço.

\section{$* * *$}

A separação característica do Estado é, em primeiro lugar, como demonstra Wood (2003) a separação do político em relação ao econômico. Separação esta que funda tanto o Estado (moderno) como o capital. Com se sabe a extração do excedente nos termos do capital se dá de forma puramente econômica. Mas isto só é possível porque o Estado existe como o âmbito da pura repressão política, garantindo a imposição da propriedade privada, das formas contratuais, dos limites políticos, da hierarquização social e assim por diante.

Mas para além da pura separação entre o político e o econômico, o Estado é, como afirma Lefebvre (2004) uma cadeia de abstrações através da qual se dá a reprodução das relações sociais de produção. Abstrações estas ligadas à equalização do desigual, à separação entre o uso e a troca, entre o vivido e o concebido, entre forma e conteúdo (com a exacerbação da forma lógica e sua instituição como sócio-lógica). Uma cadeia de abstrações por meio da qual a abstração da mercadoria se torna abstração concreta.

O Estado está ligado ao capital na gênese de ambos por meio da separação entre o político e o econômico, separação diretamente ligada à acumulação primitiva. Mas as outras formas de acumulação primitiva que permanecem ao longo da história do capitalismo também se ligam ao Estado posto que este é constantemente um pressuposto das relações capitalistas de produção. O que, aliás, é demonstrado não só por Lefebvre, mas também por autores como Francisco de Oliveira, David Harvey, Giovanni Arrighi, cada um a sua maneira, como veremos mais à frente.

$$
* * *
$$

Com relação ao espaço, o que analisarei é um processo em que o espaço que se poderia chamar de natural - um espaço externo à sociabilidade - é crescentemente

\footnotetext{
${ }^{15}$ Holloway, 2003, pág. 153.
} 
transformado num espaço social, mas enquanto espaço social, em sua relação com a forma da reprodução social - caracterizada pelo Estado Moderno e pela economia capitalista - é fundamentalmente marcado por um movimento de abstração. Neste sentido, poderíamos falar de um espaço abstrato (embora o espaço social não se reduza de forma absoluta a esta condição, da mesma forma que a política e a economia também não).

O que se verifica é que o espaço enquanto dado natural se punha como uma separação a priori. A extensão em si e as condições dos territórios (em sentido meramente físico) se apresentavam como barreiras naturais ao processo de socialização. Neste sentido, o espaço era um dado organizativo, digamos por enquanto, externo às sociedades. Só para dar um exemplo, Veltz se refere a esta propriedade do espaço geométrico através da idéia de um antigo mundo bem organizado pelas distâncias ${ }^{16}$.

Com a produção de um espaço social esta propriedade do espaço geométrico enquanto separação a priori é minimizada. Para Harvey ${ }^{17}$, trata-se de uma eliminação do espaço pelo tempo. Mas como argumenta $\operatorname{Carlos}^{18}$, longe de significar o fim do espaço, estas mudanças significam, isto sim, uma reposição de seu significado. Neste sentido, seria mais interessante pensarmos em termos de uma eliminação do tempo por meio de um espaço socialmente construído, já que para Lefebvre ${ }^{19}$, a produção do espaço produz simultaneidades e sincronismos.

Mas se por um lado a separação como característica inerente ao espaço natural é crescentemente minimizada, por outro, as separações próprias do espaço social vão se reproduzindo. A abstração se apresenta, a exemplo da separação característica do capital, como uma separação entre a produção material do espaço e seu uso social. Há entre a produção de um espaço da simultaneidade e a realização desta simultaneidade um processo de intermediação, promovido pela totalidade da reprodução social, a qual se constitui do âmbito do capital e do âmbito do Estado. É justamente este processo de intermediação que se apresenta como elemento fundamental da reprodução do poder político do Estado e econômico do capital. Se considerarmos que a expansão das relações capitalistas pelo espaço depende de um processo de integração espacial, a minimização do papel do espaço enquanto distância absoluta se liga diretamente a um movimento que pode ser entendido enquanto acumulação primitiva (enquanto pressuposto das relações capitalistas) no sentido

\footnotetext{
${ }^{16}$ Veltz, 1999, p. 58.

${ }^{17}$ Harvey, 1992, p. 190.

${ }^{18}$ Carlos, 1996, p. 40.

${ }^{19}$ A produção do espaço.
} 
da instituição do capital. Enquanto isso a produção de um espaço abstrato, um espaço com separações características do poder político e do poder econômico ao possibilitar a reprodução destas formas de poder se expressa como a permanência da acumulação primitiva. 


\section{1 - A separação como origem (ou fundamento) do capitalismo.}

Sentimo-nos, pois, à vontade em lidar com cenas do passado com o único objetivo de lançar luz sobre assuntos do presente.

Karl Polanyi. A grande transformação.

Pensar em alternativas futuras ao capitalismo exige que exploremos concepções alternativas de seu passado.

Ellen Meiksins Wood, A Origem do Capitalismo.

O título acima pode parecer, à primeira vista, um tanto desencontrado em relação à proposta de trabalho que aqui se apresenta. A discussão da origem do capitalismo numa dissertação de mestrado que se propõe a sobre as transformações na economia capitalista, no Estado e no espaço durante as últimas décadas do século XX? Que sentido teria uma tal pretensão? Seria por acaso uma tentativa inglória de recontar a história do capitalismo do seu começo até nossos dias? De forma alguma. O que pretendo a seguir é delimitar a especificidade ou o fundamento do "capitalismo"1 por meio de uma reflexão sobre sua origem.

Poderia-se pôr em dúvida esta pretensão afirmando-se que a reflexão sobre o fundamento ou sobre a especificidade do capitalismo independe do perguntar-se sobre as origens e mesmo que uma tal busca, ao se embrenhar no amontoado empírico da história, tende a se perder. Então poderia vir a sugestão, "leia-se $O$ Capital, 'Os Grundrisses', ou mesmo uma obra menor do grande crítico da economia política e ali se descobrirá que o fundamento do capitalismo é a busca do lucro". Bem, se entendermos que o lucro significa a efetivação do processo de valorização do capital, não há dúvida que está aí a característica fundamental do capitalismo. No entanto, o que procuro esclarecer com o par

\footnotetext{
${ }^{1} \mathrm{O}$ termo capitalismo é bastante genérico e, portanto, a forma como aqui se entende suas relações com os conceitos de capital, modo de produção capitalista ou, ainda, formação econômico-social capitalista, deve ser esclarecida. Este esclarecimento é de importância central para o presente trabalho mas, ao mesmo tempo, não é de fácil execução. Não se trata de simplesmente definir, mas sim de demonstrar. Assim sendo, acredito que com o desenvolvimento da argumentação tais relações vão se tornando mais claras. De qualquer forma, no excurso a seguir, farei algumas considerações preliminares sobre o assunto.
} 
fundamento/especificidade é algo que realmente está posto nas obras de Karl Marx ${ }^{2}$, mas que muitas vezes fica mal entendido.

Para começar, a busca do lucro não é a especificidade do capitalismo. Para o próprio Marx ela existia nas sociedades antigas, mesmo que nos poros, nos seus interstícios. Assim sendo, a atitude de acumular por acumular também não pode ser vista como o fundamento do capitalismo. Mas então se dirá que a busca do lucro era uma exceção que, no capitalismo, se tornou regra. Não há como negar - estamos nos aproximando bastante da especificidade do capitalismo. Mas ainda faltam alguns pontos muito importantes. Em primeiro lugar há que se questionar - e esse questionamento tem importância central neste trabalho - se a busca do lucro no capitalismo se dá da mesma forma como se dava antes dele. Em segundo lugar, porque algo que era uma possibilidade particular, uma exceção, veio a se tornar uma necessidade geral?

A primeira pergunta poderia, aparentemente ser respondida sem uma reflexão sobre as origens, mais facilmente que a segunda. A busca do lucro no capitalismo está ligado à extração da mais-valia, isto é, ao tempo de trabalho não pago ao trabalhador. Neste caso para se buscar o lucro é preciso que o trabalho seja o mais produtivo possível, com o que se chega à conclusão de que a busca pelo lucro no capitalismo ocorre através da maximização da produtividade do trabalho. Tudo bem, está posta, em linhas gerais e de forma bem simplificada, a especificidade do capitalismo, mas esta posição é, ainda, insuficiente em si mesma e, ainda mais, para se refletir sobre o fundamento. Nisto se pode verificar mais uma dupla insuficiência que duas insuficiências separadas, uma vez que não está aí demonstrada a necessidade, presente no capitalismo, de se buscar lucro desta forma. E se esta necessidade não está demonstrada não se está tratando, ainda, do fundamento do capitalismo, posto que se entendido como aquilo que funda este tipo de sociedade, o fundamento é justamente a passagem da busca do lucro por meio do aumento da produtividade do trabalho de uma condição de possibilidade para uma condição de necessidade. É neste sentido que é preciso pensar na origem do capitalismo, ou seja, na sua criação.

Mas segundo Lefebvre "há muito que o conhecimento hesita diante da criação. $\mathrm{Ou}$ esta parece irracional, espontaneidade que surge do desconhecido e daquilo que não é possível ser conhecido. Ou então a criação é negada e se reduz ao que nasce daquilo que já

\footnotetext{
${ }^{2}$ Como se verá mais à frente, mesmo um texto curto como o Capítulo VI Inédito de O Capital pode ser bem esclarecedor acerca da especificidade do capitalismo.
} 
existia"3. Essa atitude fugidia diante do questionamento acerca das origens é própria de um conhecimento dominado pelo pragmatismo. Ou melhor, com a separação entre ciência e filosofia, teria ficado reservado a esta última o direito de se perguntar sobre as origens e os sentidos dos processos sociais. Enquanto isso nas mãos das ciências estaria a capacidade de intervir na realidade, mesmo com uma intervenção marcada pelo não questionamento de seu próprio sentido. Nestes termos têm-se uma teoria sem prática, pois não é dado à filosofia o direito, ou a legitimidade, de interferir na realidade. Mas, ao mesmo tempo, encontramos uma prática sem teoria, uma prática legitimada pela própria prática, pelos problemas do dia-a-dia, isto é, um pragmatismo.

A teoria crítica da tradição marxista tem como objetivo superar esta separação entre filosofia e ciência, assim como entre teoria e prática ${ }^{4}$. Sem ela, ficar-se-ia com a tradição do pragmatismo, na qual o não questionamento das origens dos processos sociais tende a levar a uma naturalização destes mesmos processos e, ao mesmo tempo, a uma compreensão limitada de suas especificidades. É o que demonstra a historiadora Ellen Meiksins Wood em seu pequeno, mas muito esclarecedor, livro A Origem do Capitalismo.

Wood faz uma revisão dos debates sobre a transição do feudalismo para o capitalismo, chamando a atenção para o fato de ser quase geral a tendência - seja no modelo mercantil representado por Adam Smith, Max Weber ou Fernand Braudel (com variações entre eles), seja nos modelos marxistas mais tradicionais de Maurice Dobb, Paul Sweezy e Rodney Hilton - a pressupor o impulso por maximizar os lucros por meio do aumento da produtividade do trabalho, característico do capitalismo, como um comportamento quase universal. A não realização destes impulsos, ou pelo menos sua não generalização, dever-se-iam a obstáculos sociais ou tecnológicos. Assim sendo, em geral a discussão sobre a origem do capitalismo foi marcada por argumentações circulares, isto é, que acabaram presumindo a existência prévia do capitalismo para depois mostrar seu surgimento, o qual seria identificável como uma remoção dos obstáculos que anteriormente impediam sua generalização.

Para alguns a remoção de tais obstáculos, como os ligados à limitada produtividade ou ao isolamento espacial, se deu pelo desenvolvimento tecnológico, daí a corrente do determinismo tecnológico. Para outros, a mudança de mentalidade, por exemplo na religião, é que teria eliminado obstáculos sociais à acumulação. Por sua vez, nas teorias de

\footnotetext{
${ }^{3}$ Lefebvre, 1991, p. 51.

${ }^{4}$ Habermas, 2000.
} 
Dobb e Hilton, por exemplo, os mesmo processos que levaram à dissolução do feudalismo teriam promovido a ascensão do capitalismo. Neste caso se subentende que o impulso capitalista já existia nos interstícios do feudalismo e a dissolução deste teria levado necessariamente ao nascimento daquele.

De qualquer forma, por mais que difiram entre si, essas análises não explicam a generalização da acumulação como uma imposição ao conjunto da sociedade. O impulso por acumular parece estar sempre pressuposto. Isso leva, mesmo que não intencionalmente, à impressão de que tal impulso é inerente à natureza humana ou algo que o valha. $\mathrm{O}$ resultado político dessa idéia é problemático. Pode-se ver no capitalismo a realização das tendências naturais da humanidade ou, pelo menos, pode-se perder a perspectiva de uma incompatibilidade entre o impulso capitalista por acumular e os projetos de realização da humanidade do homem como o fim da alienação, por exemplo.

Partindo da polêmica gerada por Robert Brenner na década de 1970 - ao publicar na edição de julho-agosto de 1977 da revista New Left Review um artigo intitulado "The origins of capilalist Development: A critique of Neo-Smithian Marxism" - Wood procura mostrar que a origem do capitalismo deve ser identificada com a transformação do mercado em uma compulsão generalizada, a qual tornaria necessária a constante busca pela maximização dos lucros por meio do aumento constante da produtividade do trabalho. Essa generalização das relações de mercado teria ocorrido a partir da imbricação de um conjunto de condições sociais próprias do campo inglês no século XVI, as quais resumirei a seguir ${ }^{5}$.

Para começar, Wood destaca que a Inglaterra teve uma unificação efetiva muito antes de outros países europeus. Como unificação efetiva estão incluídas características como a unificação política por meio da eliminação da chamada "soberania fracionada", própria do feudalismo, a concentração das funções de regulamentação econômica no Estado central e um conjunto de padrões espaciais, entre eles a existência de grande diversidade de estradas interligando o território e uma polarização gerada pela cidade de Londres. Estas características eram o sinal de um "mercado nacional em desenvolvimento", mas como veremos a seguir as condições para a formação do mercado nacional inglês não são vistas pela Autora como causas da formação do capitalismo. Na sua argumentação elas são mais identificadas como as condições para o processo de

\footnotetext{
${ }^{5}$ As idéias presentes nos próximos parágrafos são uma interpretação minha sobre a argumentação de Ellen Wood entre as páginas 82 e 88 do livro A Origem do Capitalismo.
} 
generalização do comportamento propriamente capitalista de maximização do lucro por meio do aumento da produtividade ${ }^{6}$.

Um ponto sem dúvida fundamental para apreender a argumentação de Wood é o destaque dado às características específicas das relações de classe predominantes na Inglaterra em comparação com o restante da Europa. Por um lado, o processo de desmilitarização da classe dominante era muito mais adiantado que no continente. Este é um dos fatores (apesar de não ser o único) que explica a escassez de poderes extraeconômicos para a extração do excedente por parte da aristocracia inglesa. Mas por outro lado, esta mesma aristocracia já se apoiava numa concentração da propriedade da terra bem acima do comum, isto já mesmo antes do processo de cercamentos ocorrido entre os séculos XVI e XVII. Devido a esta concentração fundiária a maioria dos produtores rurais era constituída por arrendatários e não por camponeses.

Enquanto em geral a extração de excedente por parte da classe dominante era realizada por meio da coação direta, por meio de instrumentos extra-econômicos de pressão, na Inglaterra a relação era bastante diferente. Apesar do Estado inglês não fornecer instrumentos de coação extra-econômica à sua aristocracia, como fazia, por exemplo, o Estado francês durante o absolutismo, ele garantia a legitimidade da propriedade da terra. Assim sendo, o poder da classe dominante inglesa era muito mais baseado no monopólio sobre os meios de produção que no monopólio da violência. Era, portanto, um poder que poderíamos definir mais como econômico do que como político ${ }^{7}$.

Este poder econômico era usado para pressionar os produtores a aumentarem o excedente por meio do aumento dos aluguéis, crescentemente cobrados em dinheiro. Este processo foi levando os produtores a dependerem cada vez mais do sucesso no mercado para se reproduzirem. Por um lado, porque a necessidade de pagamento em dinheiro os levou a dependerem cada vez mais da venda de seus produtos, os quais tinham que ser cada vez mais competitivos no contexto de um mercado nacional cada vez mais unificado, no qual as condições de competitividade eram cada vez mais presentes. Mas, por outro lado, porque o próprio acesso a terra passou a se dar por meio de um "mercado de

\footnotetext{
${ }^{6}$ Aqui já é interessante observar que a produção de um espaço que minimize o tempo de deslocamento, isto é, de um espaço que integre, portanto, a eliminação do espaço enquanto extensão, é a condição fundamental para generalização das relações econômicas propriamente capitalistas, posto que só com a integração espacial podem se instituir relações de mercado propriamente ditas. Esta dimensão do espaço será discutida no capítulo 4.

${ }^{7}$ As discussões sobre a separação entre o econômico e o político assim como sobre as relações entre o Estado e as relações de mercado serão feitas no capítulo 4.
} 
arrendamentos". Este mercado de arrendamentos constituiu-se como uma pressão pelo aumento dos aluguéis que não vinha diretamente da decisão dos proprietários, mas sim das próprias condições de concorrência pelo acesso á terra.

A dupla exigência de competitividade sobre os arrendatários - por um lado a competição para vender os produtos, por outro a competição pelo acesso à terra, cada vez mais cara - tornou a busca do lucro por meio do aumento da produtividade do trabalho uma necessidade. Daí surgiu uma pressão competitiva que foi, com o tempo, se generalizando entre os arrendatários e, posteriormente, mesmo entre os pequenos proprietários que cultivavam suas próprias terras. Os mais produtivos iam enriquecendo, enquanto os menos produtivos corriam o risco de ter de se juntar aos proletários cada vez mais numerosos nas cidades, pois cada vez mais, "a produção não competitiva podia significar a perda direta da terra" ${ }^{\prime 8}$.

Este é o núcleo da argumentação de Wood para demonstrar a passagem do mercado como um conjunto de oportunidades para o mercado como um conjunto de coações. Produzir para o mercado e de acordo com suas exigências foi deixando de ser uma opção para se tornar uma obrigação. Na continuidade de seu argumento, a Autora demonstra o incrível crescimento da produtividade agrícola inglesa resultante deste processo de submissão dos produtores ao mercado. Por sua vez, o aumento da produtividade teria promovido processos como a urbanização, a proletarização e a industrialização. Levando o argumento até suas últimas consequiências, Wood destaca como o padrão de produtividade inglês, decorrente do processo descrito anteriormente, passa a representar uma pressão pela maximização dos lucros por meio do aumento da produtividade nas redes de comércio já constituídas há séculos, seja na Europa, seja desta com outros lugares do mundo. Neste sentido, o desenvolvimento do capitalismo mundial poderia ser visto como uma reação à pressões competitivas do capitalismo inglês. A Autora chega a afirmar que "sem o capitalismo inglês, provavelmente não haveria nenhum tipo de sistema capitalista"9.

Pela falta de conhecimento no campo da historiografia não posso endossar ou refutar esta ousada tese e nem seria meu objetivo fazê-lo no presente trabalho. O que me interessa na argumentação da Autora - e neste sentido concordo plenamente com ela - é a sua capacidade de apreender a especificidade do capitalismo, que para ela é justamente a generalização das relações de mercado como imperativo a ser seguido pelas pessoas em

\footnotetext{
${ }^{8}$ Wood, 2001, p. 84.

${ }^{9}$ Wood, 2001, p. 110.
} 
sua busca pela reprodução social. É claro que este ponto de vista não é novo. Ele se origina de uma leitura rigorosa da obra de Marx. Portanto da mesma forma que está presente na obra de Ellen Wood pode estar também na de muitos outros marxistas. Para destacar um outro autor cujas idéias influenciaram bastante este trabalho, em termos lefebvrianos, por exemplo, esse mesmo processo poderia ser descrito como a generalização do mundo da mercadoria, isto é, um mundo no qual as relações sociais são crescentemente mediadas pela forma da mercadoria. No entanto, é preciso destacar que a forma como Wood coloca o problema foi importante para o desenvolvimento de uma maneira particular - do presente autor - de apreender não a origem do capitalismo, mas seu fundamento. Seu fundamento não como o processo que o fundou no século XVI, mas como o elemento que o funda todos os dias, a reprodução mediada pelo mercado.

A discussão da fundação do capitalismo, da sua origem, em geral é pautada no debate sobre a acumulação primitiva. Esta, por sua vez, é muitas vezes vista como o acúmulo original de capital por parte da burguesia por meio do qual esta pode passar a explorar o proletariado. Em geral esse acúmulo original é diretamente ligado ao processo de cercamentos ocorrido no campo inglês durante os séculos XVI e XVII, que por sua vez é posto como a criação da propriedade privada sobre os meios de produção, no caso a terra, que separou, de um lado, os detentores dos meios de produção e, de outro, os trabalhadores assalariados privados do acesso a esses mesmos meios de produção. Essa idéia está claramente presente no capítulo XXIV de $O$ Capital, no qual Marx se propõe a discutir o processo de acumulação primitiva.

No capítulo 4 serão discutidos os detalhes da visão de Marx sobre o processo de acumulação primitiva, presentes em $O$ Capital, assim como a visão de outros autores sobre o mesmo assunto. Mas, por enquanto, terei de pôr um questionamento que, talvez, pareça, ainda, mal fundamentado. A questão é sobre a identificação imediata entre acumulação primitiva e origem do capitalismo, seriam estes dois processos tão identificáveis - a ponto de serem o mesmo - como se costuma fazer? Bem, que no período no qual se originava o capitalismo ocorreram processos de acumulação primitiva, disso não resta dúvida. Mas, será que a acumulação primitiva levou à formação do capitalismo, ou teria sido este mais uma causa do outro processo? 
Se identificarmos o capitalismo pelo fundamento posto por Wood, poderíamos defini-lo como uma regra de reprodução ${ }^{10}$ social que leva produtores e proprietários a se submeterem cada vez mais às relações de mercado para se reproduzirem. Neste sentido, a criação da propriedade privada como um direito de uso exclusivo sobre os meios de produção por parte dos proprietários - que é o que normalmente se entende como acumulação primitiva - é insuficiente para explicar a submissão destes às relações de mercado. Ou seja, por que só pelo fato de poderem exigir dos trabalhadores uma produtividade cada vez maior para maximizar os lucros, os proprietários efetivamente o fariam? Porque não continuariam a procurar outras formas - formas não propriamente capitalistas - de aumentar seus rendimentos? A busca dessa resposta é fundamental para grande parte da argumentação posterior deste trabalho, portanto vamos a ela.

Mesmo que inicialmente o argumento de Wood ponha em destaque a submissão dos arrendatários ao mercado de arrendamentos como forma de explicar as relações de mercado como um conjunto de imperativos que levou à generalização das relações capitalistas, posteriormente a Autora tem, obrigatoriamente, que demonstrar como esse conjunto de imperativos passa a funcionar também sobre os proprietários e, mais além sobre as economias de outros países europeus. Segundo a análise crítica da Autora esse processo de expansão do capitalismo a partir do campo inglês para toda a Inglaterra e daí para o mundo costuma ser visto como o aproveitamento das relações de mercado como um conjunto de oportunidades que foram se expandindo e levando as pessoas a as aproveitarem. Este tipo de análise sofre, justamente, daquilo que a Autora se propõe a negar, isto é, a pressuposição de que sempre que as pessoas sejam expostas às oportunidades do mercado elas tendem a aproveitar tais oportunidades, como se estas fossem em si boas, ou como se as pessoas fossem naturalmente propensas a este tipo de comportamento que visa tirar vantagens lucrativas das relações sociais.

Ao contrário dessa visão continuísta/evolucionista, que põe o capitalismo quase como uma tendência natural da humanidade, Wood procura identificar uma ruptura, algo que tenha passado a obrigar as pessoas a se comportarem de forma capitalista. Esse algo é justamente a instabilidade produzida pelas relações de mercado. O que a Autora identifica nas transformações da estrutura de propriedade do campo inglês no século XVI, a meu ver, não é bem a instauração da propriedade privada dos meios de produção como algo garantido de forma absoluta como um direito dos proprietários, mas, ao contrário, o que

\footnotetext{
${ }^{10}$ Wood utiliza esta expressão remetendo seu uso original a Robert Brenner, apesar de não identificar o texto de Brenner no qual se pode encontrá-la.
} 
tais transformações teriam promovido é um certo condicionamento da propriedade ao sucesso no mercado. Ou seja, a especificidade da propriedade capitalista é que ela não é uma propriedade politicamente constituída (termo que a autora utiliza para se referir à situação presente no Absolutismo francês), mas sim uma condição de propriedade que tem no mercado a sua mediação, isto é, que tem no mercado a sua condição de reprodução.

Esta especificidade da propriedade propriamente capitalista pode ser verificada em alguns apontamentos sobre os cercamentos. Para além da criação de limites físicos, como as cercas, entre as propriedades, os cercamentos podem ser entendidos como um conjunto de processos que foram eliminando os direitos tradicionais de uso da terra e substituindoos pelo direito de uso exclusivo da terra para a geração de lucros. Nesses processos muitos embates se deram entre grupos que tinham direitos tradicionais de uso sobre as mesmas terras e, para utilizá-las de forma lucrativa, precisavam excluir o direito dos outros sobre o uso de tais terras. Segundo Wood, com o passar do tempo, os tribunais foram reconhecendo o direito de propriedade sobre a terra de acordo com a lógica do "melhoramento". Por melhoramento a Autora entende o uso lucrativo da terra.

Inclusive a discussão sobre o melhoramento se estende à teoria da propriedade de John Locke, para quem a propriedade de alguém sobre algo se justifica pela mistura que ocorre entre o trabalho que partiu de seu corpo (corpo este que seria, a priori, uma propriedade privada) com a coisa que, antes de sofrer a ação do trabalho, fazia parte do conjunto da natureza. Locke é famoso por lançar as bases da idéia de valor-trabalho presentes mais tarde nos economistas políticos e em Marx, sem, é claro, denunciar o fato de que o trabalho empregado sobre uma mercadoria, no capitalismo, nem sempre (na verdade quase nunca) partiu do corpo do capitalista, mas, ao contrário, de seu empregado. Mas a teoria da propriedade de Locke é acima de tudo uma legitimação teórica da propriedade propriamente capitalista, baseada na noção de melhoramento. De acordo com ela tem direito à propriedade não quem a herdou ou quem a conquistou em guerras, mas quem a "melhorou", no sentido de quem a tornou mais produtiva empregando sobre ela o seu próprio trabalho.

É de acordo com esse ideal que foram sendo decididas as disputas de terras na Inglaterra entre os séculos XVI e XVII. Neste sentido, tudo aquilo que não representasse a possibilidade de tornar a terra mais produtiva e lucrativa não era visto como legítimo em tais disputas. Segundo Wood, até o início do século XVII, quando ainda imperava na 
Inglaterra o Estado Monárquico essa lógica ainda não era absoluta, posto que os interesses não-capitalistas de uso da terra, seja dos camponeses, seja da aristocracia, mantinham alguma legitimidade. Mas após a Revolução Gloriosa de 1688, na qual a classe capitalista passou a moldar o Estado de acordo com a sua lógica, uma nova onda de decretos vindos do parlamento (dominado pela elite capitalista) varreu o campo inglês, diminuindo cada vez mais os obstáculos ao processo de acumulação.

Neste amplo processo de transição, o poder político e o poder econômico se separaram cada vez mais. A classe dominante passou a ser identificada como aquela que tem poder econômico. Poder-se-ia afirmar, numa leitura um tanto superficial das relações entre economia e política, que o poder econômico não passa de um poder político disfarçado, numa concepção de Estado como sendo o comitê da classe capitalista. A meu ver, no entanto, a relação é mais complexa ${ }^{11}$.

Por um lado, o poder econômico que identifiquei com a elite desmilitarizada da Inglaterra só pode existir porque o Estado lhe garante a validade da propriedade. $\mathrm{Na}$ discussão sobre a acumulação primitiva feita por Marx, a propriedade privada só existe por haver por trás dela a força estatal que obriga o respeito a ela, isto é, sem o monopólio da violência não existe monopólio dos meios de produção. Por outro lado, no caso discutido por Wood, há um deslocamento real entre a ação do Estado para garantir a existência da propriedade e a legitimação dessa mesma propriedade. Não é qualquer situação de propriedade que é protegida pelo Estado, mas apenas aquela que é legitimada no âmbito do mercado. Se um fazendeiro perde suas terras por ter ido à falência ele não poderá - de acordo com as normas da propriedade propriamente capitalistas - reavê-las por meios políticos. É neste sentido que afirmei acima que a propriedade passa a ser mediada pelo mercado.

Podem se fazer objeções a este quase purismo em relação às ações do Estado em relação à economia. Pode se colocar em xeque a idéia de que o Estado deixa as forças de mercado agirem na legitimação da propriedade. A meu ver tais objeções estariam cobertas de razão. Acreditar que houve uma separação absoluta entre a política e a economia e que a

\footnotetext{
${ }^{11}$ No capítulo 4 as relações de classe serão tratadas com mais atenção, mas como observação preliminar poderia afirmar que na relação entre Estado e capital se produz uma condição segundo a qual a elite capitalista para manter o seu poder pode utilizar-se do Estado mas, ao mesmo tempo, tende a ser obrigada a cumprir as exigências do processo de valorização que, em certa medida, lhe escapa. Isso mesmo no uso do aparelho estatal. Temos, desta forma, uma situação na qual os "grupos dominantes" defrontam-se com novas condições para reproduzirem esta situação privilegiada.
} 
primeira passou a funcionar propriamente de acordo com a segunda seria um equívoco. No entanto, como já frisei, o processo analítico se constitui como um processo de abstração mental. Se quisermos identificar a característica específica de um elemento é preciso, num primeiro momento, desconsiderar os outros. Aliás, pelo que me consta, essa é uma das lições metodológicas deixadas por Marx no trato com o capitalismo. Em sua teoria, ele procura partir dos mesmos pressupostos dos economistas políticos - que acreditam no funcionamento do livre mercado - para em seguida demonstrar como, mesmo assim, o capitalismo é contraditório. Não é por acaso que o capítulo sobre a acumulação primitiva seja o único de $O$ Capital que dê destaque para métodos não-capitalistas de reprodução do poder. Afinal, em sua obra econômica, Marx tinha o objetivo de compreender a acumulação propriamente capitalista para identificar seus fundamentos e suas contradições.

Para fechar este item faz-se necessária uma pequena síntese que deverá servir para justificar - ao menos é o que espero - as discussões aqui realizadas acerca da origem do capitalismo com base nas idéias de Ellen Wood. Procurei não apenas produzir um resumo de tais idéias, mas sim extrair delas um primeiro apontamento sobre as separações no âmbito do capital. Talvez a relação ainda não tenha ficado clara e, por isso, gostaria de explicitá-la a seguir.

O que as idéias de Ellen Wood demonstram, a meu ver, é que o que chamamos de capitalismo é algo muito específico na história dos últimos séculos. Esta especificidade só pode ser encontrada na identificação do papel do mercado na economia capitalista. O mercado é, em geral, considerado como um conjunto de possibilidades e, em muitas situações históricas talvez ele tenha sido realmente isso ${ }^{12}$. No entanto, o que a Autora procura mostrar é a característica distintiva das relações de mercado que fundam o capitalismo. Neste caso o mercado deixa de ser um conjunto de possibilidades para se tornar um conjunto de coações.

\footnotetext{
${ }^{12}$ Braudel (1989), por exemplo procura classificar as relações econômicas em três tipos: a vida material (correspondente à ações das pessoas para garantirem seus necessidades materiais diárias), o capitalismo (identificado por ele como as ações das grandes empresas ligadas aos grandes governos) e a economia de mercado, vista por ele como um conjunto de possibilidades de trocas materiais e imateriais que levam ao dinamismo social em múltiplos sentidos. Da mesma forma, Henri Lefebvre (Del’Etat, Revolução Urbana, Direito à cidade) considera esse "lado" do mercado como o local, ou o âmbito, no qual se dão as trocas materiais e imateriais, como o lugar das possibilidades. Mesmo demonstrando em sua obra a redução de tais possibilidades no contexto da reprodução capitalista, tal autor parece manter um certo grau de utopia em relação a tais possibilidades, o que fica claro nas possibilidades apontadas por ele em relação à sociedade urbana.
} 
Esta mudança das relações de mercado se dá pelo fato das pessoas passarem a ter sua condição de reprodução mediada pelo mercado. É nesta mediação promovida pelo mercado que podemos identificar o fundamento do capitalismo como uma separação. $\mathrm{O}$ mercado passa a ser a cisão entre a necessidade e sua realização. A reprodução da condição social de cada um - seja do trabalhador, seja do proprietário - é cindida de forma que ela não pode mais ser a determinação fundamental da sua própria realização. Este é o lugar no qual as relações de mercado se instalam, levando o processo de reprodução privado a efetivar a reprodução do capital. Mas esta separação não é absoluta, afinal se o fosse significaria a não reprodução. Ao contrário, é uma separação que põe a necessidade de um movimento no sentido de sua superação, sob pena de gerar as mais graves crises no processo de reprodução social. É o que deverá ser esclarecido no próximo capítulo. 


\section{Primeiro Excurso sobre encontros e desencontros metodológicos}

No capítulo anterior discuti as idéias de Ellen Wood sobre a origem do capitalismo buscando extrair delas uma interpretação particular sobre o seu fundamento. Segundo tal fundamento o capital não pode ser identificado com coisas como os meios de produção, o dinheiro ou as mercadorias. Ele tem de ser identificado como uma forma de relação social. Uma forma que pode ser descrita como uma regra de reprodução de acordo com a qual os agentes sociais têm de cumprir as exigências da acumulação para realizarem suas próprias necessidades de reprodução. Nos próximos capítulos pretendo prosseguir minha busca por delimitar de forma mais rigorosa este fundamento do capital. Mas antes é necessário e, espero, enriquecedor, promover algumas reflexões de caráter metodológico. Não sobre o método por mim usado na elaboração do presente trabalho, mas sobre alguns aspectos metodológicos da obra de Wood e dos autores que serão analisados a seguir.

A abordagem anteriormente considerada é claramente histórica, o que não significa uma limitação a procedimentos empíricos mas sim uma tendência a construir o discurso com base em análises de transformações históricas específicas, nelas encontrando a origem do que a autora entende como capitalismo. O que chama a atenção neste tipo de abordagem é que não é posta (o que não significa que não seja pressuposta pela autora desde o início de seus estudos) uma definição abstrata de capitalismo, uma definição aplicável a qualquer caso. Mesmo que se possa encontrar na introdução de seu A Origem do Capitalismo, uma definição do que é ali entendido por capitalismo ${ }^{1}$, sua démarche não vai no sentido de aplicar esta definição para diferentes casos concretos, mas, ao contrário, procura demonstrar a especificidade deste sistema econômico a partir da especificidade - temporal e espacial - de sua origem ${ }^{2}$.

A meu ver, o ponto positivo deste viés é, justamente, não pôr o capitalismo como um sistema dominante de forma absoluta e geral desde que surgiu e em todos os lugares aos quais tenha chegado. Fica subentendida a constante incompletude da instauração do

\footnotetext{
1 “O capitalismo é um sistema em que bens e serviços, inclusive as necessidades mais básicas da vida, são produzidos para fins de troca lucrativa; em que até a capacidade humana de trabalho é uma mercadoria à venda no mercado; e em que, como todos os agentes econômicos dependem do mercado, os requisitos da competição e da maximização do lucro são as regras fundamentais da vida [...]” Wood, 2001, p.12.

${ }^{2}$ Prova disso é a afirmação um tanto ousada (e reconhecida pela própria Ellen Wood como a mais controversa) de que "sem o capitalismo inglês provavelmente não haveria nenhum tipo de capitalismo". Wood, 2001, p.12.
} 
capitalismo e permanência de prováveis especificidades, nacionais, regionais ou mesmo locais (esta perspectiva nos será muito útil a partir do capítulo 4).

Mas, por outro lado, o caráter histórico da metodologia de Wood faz com que ela não discuta os meandros do funcionamento do capitalismo como sistema econômico, independentemente do que ocorreu na Inglaterra do século XVI. Esta observação não é uma crítica à autora, até porque, como ela mesma deixa muito claro a todo o momento, tal discussão não está entre seus objetivos. Mesmo sem querer fazer esta crítica - e isso não é uma atitude parcimoniosa, mas antes um cuidado para manter a clareza dos limites entre os métodos utilizados nos diversos âmbitos das ciências humanas - preciso chamar a atenção para tal limitação para poder, inclusive, seguir em frente, justificando a busca por outras formas de ver o capitalismo, formas que complementem - de acordo com os objetivos do presente trabalho - aquela primeira.

É a esta complementação ao entendimento dos fundamentos do capitalismo que se referem os dois próximos capítulos. Antes de iniciá-los, no entanto, vejo como necessários alguns esclarecimentos sobre as diferenças de enfoque destes em relação ao primeiro. Como acabo de afirmar, o viés de Wood é claramente histórico. Enquanto isso, as obras dos autores nas quais se baseiam os capítulos 2 e 3 apresentam um caráter mais teóricoconceitual. Vejamos alguns detalhes importantes sobre tais obras antes de tecer os comentários adequados acerca deste caráter teórico-conceitual e de suas relações com a perspectiva por mim adotada.

Todos os trabalhos aos quais vou me referir agora são - alguns de forma mais restritiva outros nem tanto - estudos centrados na obra econômica de Marx. Um deles é o livro já clássico de Ruy Fausto, Marx: Lógica e Política $I^{3}$. Neste caso, o que temos é um conjunto de textos que têm como objeto algumas leituras de Marx consideradas equivocadas por parte de Fausto (mas mesmo assim, vistas por ele como "grandes leituras"). Nos dois capítulos do livro que mais interessam ao presente trabalho as leituras

\footnotetext{
${ }^{3}$ Marx:Lógica e Política não é apenas o titulo de um livro mas de um projeto, ainda incompleto, de "reconstituição do sentido da dialética" iniciado por Ruy Fausto na década de 1970. O todo do projeto é constituído por cinco volumes, sendo que os três primeiros já foram publicados (Brasiliense, 1983; Brasiliense, 1987; Editora 34, 2002, respectivamente). Destacando, ainda, a existência de um complemento intitulado Dialética Marxista, Dialética Hegeliana: O Capital e a lógica de Hegel, este dividido em três volumes, dos quais apenas o primeiro foi publicado no Brasil (Paz e Terra/Brasiliense, 1997). Até o momento de elaboração do presente trabalho a limitação de tempo e a necessidade de fazer outras leituras (afinal o estudo da teoria de Marx é apenas um entre vários caminhos que procuro trilhar em meu processo de formação) me permitiram conhecer apenas o clássico volume 1. É o seu conteúdo que deve, portanto, ser considerado como influência sobre este trabalho.
} 
criticadas são as de Cornelius Castoriadis (capítulo 3) e Benetti e Cartelier (capítulo 4) ${ }^{4}$. O interessante é que ao fazer tais críticas, o autor expõe importantes elementos para o entendimento da dialética marxista. Aliás, não é à toa que o subtítulo de sua obra seja, justamente, "investigações para uma reconstituição do sentido da dialética".

Muito próxima à perspectiva de Fausto está a de Jorge da Silva Grespan, destacando-se a sua tese de doutoramento $O$ Negativo do Capital. Em tal obra, Grespan se propõe a fazer um estudo do conceito de crise na obra de Marx, com destaque para $O s$ Grundrisses, As Teorias da Mais-Valia e O Capital. Devido ao seu caráter teóricoconceitual, este estudo não faz referências à história do desenvolvimento capitalista e, nem mesmo, a sua crise atual. Ao invés de analisar esta ou aquela manifestação da crise, o objetivo de Grespan é produzir uma discussão por meio da qual "se poderá definir até que ponto as várias perspectivas antagônicas [a respeito do conceito de crise] se enraízam legitimamente no que a teoria de Marx permite afirmar e a partir de que ponto as deduções delas ultrapassam as possibilidades da teoria matriz, assumindo uma feição exagerada, errônea e dogmática $5 "$. Ou seja, o autor procura demonstrar o que se pode e o que não se pode dizer sobre o conceito de crise a partir dos textos de Marx. Assim sendo, mesmo extrapolações na direção de textos de outros marxistas são raras em tal obra.

O resultado do admirável esforço de Grespan é uma reconstituição detalhada do percurso de Marx na construção do conceito de capital entremeado com a construção do conceito de crise. Esta reconstituição respeita, inclusive, o método de exposição de Marx, o qual como vimos segue um caminhar do abstrato ao concreto. Com isso, o que se tem é uma demonstração da crescente concreção tanto do capital como da crise.

A proximidade entre Fausto e Grespan está, entre outros pontos, na explícita consideração da filosofia de Hegel como suporte para o entendimento dos textos marxianos. Isto não significa, é claro, o entendimento de uma continuidade imediata entre a obra de Marx e Hegel, mas sim a consideração do caráter crítico da dialética marxista em relação à hegeliana ${ }^{6}$. Graças a esta consideração o que temos são duas leituras de Marx que demonstram os problemas de se fazer uma leitura deste autor sem atentar para o sentido

\footnotetext{
${ }^{4}$ Refiro-me ao capítulo 3 - Abstração Real e Contradição: sobre trabalho abstrato e valor - e ao capítulo 4 Circulação de Mercadorias, Produção Capitalista. Meu interesse em ambos se refere não diretamente ás críticas feitas a tais leituras, mas sim ao conteúdo conceitual marxista que as críticas envolvem.

${ }^{5}$ Grespan, 1998, p. 31.

${ }^{6}$ Como caráter crítico entendo não uma simples negação, mas sim uma negação que inclui a manutenção de uma potência crítica (ao capitalismo) que já estava implícita na obra de Hegel. Na verdade um caráter crítico que só se mantém com a crítica à dialética hegeliana.
} 
crítico de sua dialética. Algumas de suas conclusões - por exemplo sobre a relação entre trabalho concreto, trabalho abstrato, valor e valor-de-uso em Fausto e sobre a crise em Grespan - deixam claro o quanto a atenção para este sentido crítico é fundamental para o real entendimento de muitos dos conceitos marxianos.

Valor e Capitalismo, tese de doutoramento de Luiz Gonzaga de Mello Belluzzo é outro texto de grande importância para o presente trabalho. Nele o autor procura fazer uma crítica às leituras que encontraram na obra de Sraffa uma "chave que permitiria a Marx abrir as portas da respeitabilidade acadêmica ${ }^{7}$." Infelizmente não está ao alcance de minha formação avaliar tais críticas considerando a obra de Sraffa, justamente pelo seu desconhecimento. No entanto, a maneira como Belluzzo faz as críticas acaba sendo uma importante colaboração ao entendimento da teoria do valor de Marx.

Ao contrário de Grespan e Fausto não se pode reconhecer em Belluzzo a consideração explícita da obra Hegel na leitura dos textos de Marx. Enquanto nos dois primeiros o viés crítico de Marx é reconhecido mais especificamente na relação entre a dialética marxista e a dialética hegeliana, no caso de Belluzzo este caráter é extraído da relação entre a teoria econômica marxista e os pressupostos da economia política clássica ${ }^{8}$. Esta diferença, no entanto, não desqualifica a obra de Belluzzo que, a meu ver, mantém uma leitura da obra de Marx na qual não se perde seu sentido dialético (mesmo que o autor não fale de dialética, o que aliás, o próprio Marx faz pouco).

A última obra de grande influência sobre os próximos capítulos é a de David Harvey, com destaque para seu impressionante livro The Limits to Capital. Há uma diferença na forma de tratamento que este livro propõe em relação ao estudo da teoria econômica marxista e os outros três considerados anteriormente. Enquanto Fausto, Grespan e Belluzzo se mantêm nos limites da interpretação dos textos de Marx - com exceção de poucas extrapolações - Harvey problematiza toda a estrutura teórica da economia marxista considerando não apenas os textos de Marx como também de um grande número de autores marxistas e não marxistas, desde os mais clássicos da Segunda Internacional até os debates da década de 1970.

\footnotetext{
${ }^{7}$ Belluzzo, 1987, p. 15.

${ }^{8}$ Isso não significa que as relações entre Marx e os clássicos da economia política não sejam consideradas. Apenas entendo que em Belluzzo esta relação está mais explícita, provavelmente até pela proximidade do autor em relação à história do pensamento econômico, diferentemente do caso de Fausto e de Grespan que se aproximam mais da história do pensamento filosófico.
} 
Mas além desta extrapolação bibliográfica também é marcante na obra de Harvey uma extrapolação temática. Em seu The Limits to Capital ${ }^{9}$, o autor procura tratar as contradições do capital e as formas como as empresas, o Estado e os trabalhadores lidam com tais contradições. Com isso, apesar de tratar diretamente da teoria das crises ele não se limita a discuti-la de forma apenas conceitual, ao contrário, tenta explorar uma ampla gama de possibilidades de desdobramentos efetivos das contradições do capital.

Buscando dar conta das discussões feitas nesta perspectiva, Harvey divide seu livro em três "cortes" sobre as teorias das crises econômicas, cada um deles devidamente antecedido por uma ampla discussão dos conceitos e das problemáticas que o envolvem. O primeiro corte se refere ao problema das contradições próprias da produção capitalista, desde as contradições internas à mercadoria até a problemática da queda tendencial da taxa de lucro, passando pelas relações entre mercadoria e dinheiro, entre produção e circulação, entre mais-valia relativa e a mudança tecnológica e assim por diante. $\mathrm{O}$ segundo corte se refere aos aspectos financeiros e monetários da formação das crises. O terceiro se relaciona a teorias sobre a geografia histórica do modo de produção capitalista, isto é, aos aspectos temporais e espaciais que se ligam às crises do capitalismo. Estas extrapolações e esta diversidade nos permitem e mesmo exigem reunir a obra de Harvey a de outros autores (como Henri Lefebvre, Guy Debord, John Holloway, Francisco de Oliveira, para citar alguns nomes importantes para o presente trabalho) que buscam uma superação do pensamento de Marx. Mas que se entenda desde já, uma superação que não é uma simples negação. É preciso entendê-la como a "Aufhebung” hegeliana - isto é, uma superação que só pode ocorrer com a conservação do que está sendo superado.

Portanto, se por um lado é possível encontrar em Harvey discussões longas e detalhadas sobre a obra de Marx (a exemplo do que fazem Fausto, Grespan e Belluzzo), por outro há uma constante tendência a ir para além das idéias deste autor. Como minha opção nos dois próximos capítulos é fazer uma discussão sobre o sentido de capital limitada ao corpo conceitual marxiano (com pouquíssimas exceções), a obra de Harvey será utilizada, por enquanto, apenas dentro destes limites. Suas ricas contribuições no sentido de pensarmos para além d'O Capital ficarão "de molho" esperando para se juntar às de outros tantos autores nos três últimos capítulos.

\footnotetext{
${ }^{9}$ Neste trabalho foi utilizada a versão em espanhol Los limites del capitalismo e la teoria marxista (Fondo de Cultura Económica). No entanto, o original foi também utilizado para a conferência da tradução mexicana, assim como para auxiliar na tradução de trechos para o português como forma de citação, tradução realizada pelo próprio autor do presente trabalho.
} 


\section{2 - O capital como movimento: separação, crítica e crise.}

A tarefa imediata da filosofia, que está a serviço da história, é desmascarar a auto-alienação humana nas suas formas não sagradas, agora que ela foi desmascarada na sua forma sagrada.

Karl Marx, Introdução à Crítica da Filosofia do Direito de Hegel.

O objetivo deste capítulo, e também do próximo, não é reproduzir a formulação de Marx ou de alguns marxistas aqui considerados acerca do movimento do capital, mas sim apresentar uma leitura de tais obras que busca encontrar na noção de separação uma base para compreender o capital enquanto movimento. É importante observar desde já que é esta identificação do capital como um movimento que possibilita pô-lo como alvo da crítica, posto que é enquanto movimento que o capital tende a se autonomizar como um sujeito, “entendendo por 'Sujeito' não somente a determinação primeira de que as outras são predicados, mas um processo autônomo, um movimento que se autonomizou e se tornou uma força social"" .

Neste capítulo procurarei identificar no conceito de crise parte do impulso do capital por se tornar um movimento autônomo. Começarei chamando a atenção para a importância dada a tal conceito na leitura feita por Jorge Grespan sobre a obra de Marx. Segundo esta leitura, a crise, na obra marxiana, não é um simples momento de não realização dos objetivos do capital, isto é, uma não realização da acumulação. Para além disso, a crise é um elemento constitutivo do capital, daí a idéia de "negativo do capital". Negativo não como um outro oposto, mas como o oposto interno que, como tal, tem papel ativo na condição de movimento contraditório própria do capital.

Em minha primeira leitura do livro de Grespan (1998), realizada, ainda, nos últimos anos da graduação, me chamou a atenção uma nota bibliográfica a respeito do conceito de crise e de sua relação intrínseca com o conceito de crítica. Para esclarecer tal relação, Grespan sugeria em tal nota a leitura de três textos, dos quais só tive acesso a dois, sendo

\footnotetext{
${ }^{1}$ Fausto, 1987, p. 188. É importante observar que neste trecho Ruy Fausto está se referindo ao valor enquanto sujeito e não diretamente ao capital. No entanto, para este Autor, é justamente quando o valor se torna Sujeito como um movimento autônomo que se transformou em uma força social é que se pode falar em capital. Ou seja, entendo aqui este processo de autonomização como o fundamento do capital.
} 
estes: Crítica e Crise de Reinhart Koselleck e "Entre Ciência e Filosofia: o Marxismo como Crítica" in Teoría y Praxis: Estudios de Filosofia Social, de Jürgen Habermas ${ }^{2}$.

No livro de Koselleck (no qual Habermas também se apóia) pode-se encontrar uma pesquisa etimológica dos termos crítica e crise que aponta para uma raiz comum entre ambos - um verbo grego que significa, entre outras coisas, separar, julgar, decidir, lutar e combater. Originalmente a palavra significava tanto separação e luta como decisão e julgamento. Ou seja, “as significações, hoje separadas, de uma 'crítica subjetiva' e uma 'crise objetiva' ainda eram concebidas em grego sob um conceito comum"3. Este conceito comum se referia à jurisprudência, guardando o sentido de uma decisão a ser tomada diante de uma situação que a exigia. Ou seja, a decisão não é absolutamente subjetiva, posto que se refere a uma situação objetiva em si crítica, isto é, uma situação que exige uma resolução. O mesmo sentido pode ser observado nos usos teológico e médico do termo, mais comuns na língua latina. No campo teológico, no evangelho de São João, a crise é posta como o Juízo Final, em si um tribunal universal - novamente uma situação objetivamente crítica que leva à necessidade de sua resolução. Por sua vez, no âmbito da medicina a crise foi vista como o momento a partir do qual se pode verificar o desenvolvimento de uma doença, o momento decisivo para o julgamento sobre ela.

Nos três casos crítica e crise estão fundamentalmente ligados, já que se há uma crítica subjetiva ela se refere a uma crise objetiva. Esta crítica subjetiva não é, portanto, indeterminada. Ao contrário ela só existe como um impulso por superar a crise objetiva. Dessa forma, a relação entre crítica e crise nos remete a uma situação crítica, entendida aqui como uma condição de cisão que exige um movimento de superação. Numa formulação própria da dialética hegeliana esta condição aparece descrita da seguinte maneira:

Encontramo-nos determinados assim ou assado. Tento separar de mim esta determinidade e acabo por me cindir comigo próprio. Pelo que os meus sentimentos se convertem num mundo exterior e noutro interior. Surge ao mesmo tempo um modo peculiar de minha determinidade, a saber, que me sinto defeituoso, negativo, e encontro em mim a contradição que ameaça desfazer-me. Mas existo; eis o que sei e oponho-me à negação, à deficiência. Conservo-me e procuro anular a

\footnotetext{
${ }^{2} \mathrm{O}$ terceiro texto é o de Kurt Röttgers, Kritik und Praxis: Zur Geschichte des Kritikbegriffs Von Kant bis Marx. Berlim: De Gruyter, 1975.

${ }^{3}$ Koselleck, 1999, p. 202
} 
deficiência e, por isso, sou impulso. O objeto a que se dirige o impulso

é, então, o objeto da minha satisfação, do restabelecimento da minha unidade ${ }^{4}$.

A determinação se desenvolve como a posição do espírito, sendo, ao mesmo tempo, sua negação. É posição porque é a condição de sua efetivação como espírito. Mas é negação porque não é uma posição do espírito enquanto espírito em sua indeterminação (no sentido de indeterminismo) mas apenas uma determinação do espírito "assim ou assado". Por isso a determinação do espírito não faz dele algo per-feito (todo feito; feito do começo ao fim), isto é, em sua determinação o espírito está sempre defeituoso. Se esta determinação se efetiva de forma absoluta, o espírito se desfaz enquanto tal. Mas não é próprio do espírito permitir que isso ocorra - talvez do espírito deste ou daquele povo, em si limitado, mas não do Espírito Universal -, então ele se opõe à negação, foge de si mesmo para não deixar de ser o que é. O espírito é contraditório e, por isso, é impulso.

Esta formulação hegeliana com todo o tom idealista que lhe é característico ganha um novo sentido - um sentido de crítica - quando transposta (por meio da inversão materialista) para a descrição do movimento do capital, o que pode ser apreendido por meio do entendimento do conceito de crise. Segundo Grespan, "para resgatar em toda a sua riqueza o significado que o conceito de 'crise' tem na obra de Marx, é necessário ultrapassar o aspecto de negatividade em geral e defini-lo enquanto negatividade imanente do capital, enquanto manifestação de uma contradição constitutiva do próprio capital" ". A crise enquanto negatividade imanente é, justamente, a crise correspondente à cisão interna do próprio capital. Ou, na formulação de Grespan;
Ao contrário do sentido cotidiano da expressão "crise”, em Marx ela não significa simplesmente uma separação de dois elementos ou membros de um todo; ela indica essa separação, mas como resultado de uma relação unificadora, ou, antes, indica a própria união, revelada pelo movimento contraditório da separação ${ }^{6}$.

Neste caso a crise não deixa de ter seu significado de não-realização dos objetivos do capital, isto é, de uma não realização do processo de acumulação. No entanto, esta não realização deixa de ser vista como uma crise indeterminada (como "negatividade em

\footnotetext{
${ }^{4}$ Hegel, 1995, p. 54.[grifos meus]

${ }^{5}$ Grespan, 1998, p. 27

${ }^{6}$ Grespan, 2004, p. 179
} 
geral") e passa a ser vista como uma determinação das contradições internas ao capital. Num primeiro momento esta formulação pode ser (mal) entendida como um apontamento de que o próprio capitalismo gerará seu fim e de que este fim é inevitável. Esta conclusão, porém, não encontra subsídio naquilo que já foi afirmado e nem no que o será.

O percurso de Grespan em seu Negativo do Capital tem como uma de suas preocupações, justamente, demonstrar a implausibilidade deste tipo de conclusão. Esta demonstração tem a sua riqueza quando seguida passo a passo, o que não é possível nem desejável fazer no presente trabalho. Mas de qualquer forma é importante deixar claro desde já que afirmar que o capital possui uma negatividade imanente não equivale a dizer que tal negatividade necessariamente se efetive de forma absoluta. Ao mesmo tempo em que o capital tende a realizar sua negatividade ele tende, também, a se por como sujeito. As duas tendências são necessárias à lógica do capital e justamente por ambas serem necessárias não se pode definir uma ou outra como sendo a necessidade absoluta. Esta idéia pode ser verificada na seguinte afirmação de Grespan:

Cindido em seu interior por sua contradição essencial, o capital jamais realiza as suas tendências expansivas, não chega a constituir permanentemente sua efetividade em sentido pleno. Bem como, por outro lado, ele também nunca realiza definitivamente sua tendência à crise, na forma de um colapso inevitável ou de uma progressiva estagnação até um estado de desvalorização crônica e insuperável. Devido a esta cisão, o capital exterioriza necessariamente o seu interior - cumprindo em parte a exigência da "efetividade" hegeliana - mas um interior cujo conteúdo é duplo e antagônico ${ }^{7}$.

Vimos que se a crise pode ser considerada característica de uma separação, esta não é uma separação entre dois elementos quaisquer, mas sim uma separação entre dois elementos que pertencem a um todo. Neste sentido, talvez a crise possa ser mais bem definida como uma cisão deste todo, cisão que ao criar dois elementos que deveriam estar unidos produz uma contradição. Na formulação hegeliana o espírito cindido entre sua determinação - o que ele é como um momento (lógico ou histórico) no seu processo de efetivação - e seu ser absoluto (o que ele deve ser enquanto espírito) tende a fugir de tal determinação buscando recompor a unidade, o que só ocorrerá por meio de uma nova determinação que vá além da anterior. A determinação é a positividade do espírito, pois é a

\footnotetext{
${ }^{7}$ Grespan, 1998, p. 271.
} 
sua efetivação (é quando o espírito é posto), mas ao ser a sua positividade é, também, sua negatividade, uma vez que nunca representa a posição do espírito de forma absoluta (a não ser, como veremos com mais detalhes no próximo capítulo, quando se chega à Sociedade Civil na qual o Estado Moderno, para Hegel, cumpre o papel de criar uma identidade entre o particular e o universal, entre o determinado e o indeterminado e, desta forma, pôr um Fim à História).

Na formulação marxista - como se verá de forma mais detalhada a seguir - o capital cindido entre suas formas determinadas (mercadoria, dinheiro, capital constante, capital variável...) e o seu fundamento último (a valorização) precisa constantemente recompor a unidade por meio da qual pode efetivar tal fundamento. A crise - seja de forma clara como numa desvalorização, seja na forma latente de um constante limite à valorização - é a manifestação dessa necessidade, desse impulso do capital se recompor enquanto totalidade.

Isto, a meu ver, reafirma que entender a crise como negatividade imanente do capital não significa entender o capitalismo como pré-determinado ao colapso (mesmo sendo improvável que a humanidade consiga, por todos os problemas que isso gera, manter-se vivendo sob a necessidade de valorização por um longo período histórico). Entender desta forma a crise significa, isto sim, identificar a necessidade imanente do capital de buscar sua auto-expansão como fuga de suas próprias contradições. Neste sentido a crise é parte constituinte do impulso do capital para a autovalorização, isto é, o conceito de crise é constitutivo do próprio conceito de capital como valor que se valoriza.

Com o que foi posto até aqui espero ter feito o devido entrelaçamento entre o conceito de crise e o impulso do capital, considerando, é claro, que tal entrelaçamento é, ainda, preliminar e que será mais bem desenvolvido a seguir. Mas antes de avançarmos na explicitação desta relação é interessante colocar mais algumas idéias sobre as relações entre o conceito de crise e o conceito de crítica. Neste sentido, vale chamar a atenção para o fato de que tanto na formulação hegeliana acerca do espírito como na formulação marxista acerca do capital, a recomposição da totalidade cindida é uma mediação para a efetivação, do espírito ou do capital. A diferença, no entanto, é que para Hegel a Razão promove uma identidade entre os interesses particulares e os interesses universais, de forma a resolver as contradições (solucionar a crise). Por sua vez, na visão de Marx, a Razão é substituída pela lógica do capital, a qual realiza apenas o "seu interesse" e mantém 
o ser humano em estado de alienação. Para Grespan esta diferença se deve à inversão materialista promovida por Marx sobre a dialética de Hegel. Não aquela inversão por meio da qual Marx teria posto de cabeça para cima o que Hegel tinha formulado de cabeça para baixo (concepção que acaba chegando à idéia simplista de que a diferença entre os dois pensadores alemães é que o mais velho via as idéias como determinantes da realidade material, enquanto o mais novo via a realidade material como determinante das idéias). Mas sim um "desavessamento" da dialética, a qual em Hegel tem a identidade como essência e as contradições como aparência e em Marx tem a contradição como essência e as identidades como aparência. No primeiro, a contradição é aparente, mas está sendo resolvida pela Razão, promovendo a identidade. No segundo a identidade é aparente pois o fundamento é a contradição, a qual se manifesta na forma da crise.

E como crise e crítica andam juntas, é interessante notar que este mesmo "desavessamento", é fundamental para entender a teoria marxista como uma crítica da economia política. Para explicitar esta relação podemos dar atenção ao seguinte comentário de István Mészáros;

Exatamente como Adam Smith, Hegel adotou o ponto de vista do capital incorporando com grande sensibilidade os princípios fundamentais da economia política de Smith em sua própria magistral concepção filosófica. [...] Assim [por ter sido contemporâneo da Revolução Francesa nos principais anos de sua formação intelectual] ele não poderia deixar de atribuir à categoria dialeticamente definida da contradição um lugar de importância central em seu sistema, ainda que tratasse as relações sociais incorporadas nessa categoria de forma extremamente abstrata e idealista, atenuando assim as suas implicações explosivas no modo de reprodução sociometabólico do capital. Em muitos dos capítulos adiante, veremos como Hegel enfraqueceu e até aboliu completamente os antagonismos percebidos da dinâmica histórica objetiva em suas sínteses conciliatórias idealistas ${ }^{8}$.

O que chama a atenção nesse trecho de Mészáros é, justamente, a proximidade do ponto de vista de Hegel em relação ao da economia política clássica, a qual, assim como a filosofia hegeliana, teve seus principais fundamentos incorporados e invertidos - como

\footnotetext{
${ }^{8}$ Mészáros, 2002, p. 55.
} 
crítica - por Marx. A identidade entre Hegel e Smith e a diferença de ambos em relação ao pensamento de Marx são reafirmadas nos seguintes fragmentos;

\begin{abstract}
Por um avanço dialético, a busca subjetiva do próprio interesse transforma-se na mediação do particular através do universal, com o resultado de que ao ganhar e produzir para seu próprio gozo, cada homem está eo ipso produzindo e ganhado para o deleite de todos os demais. A compulsão que produz este resultado está enraizada na complexa dependência de cada um em relação a todos, e agora ela se apresenta a cada um como o capital permanente universal ${ }^{9}$.
\end{abstract}

Mesmo identificando a "complexa dependência" entre os indivíduos como uma compulsão, Hegel vê nesta compulsão o fundamento da identidade entre o particular e o universal. Da mesma forma, de acordo com os princípios da economia política clássica;

\begin{abstract}
A progressiva especialização dos indivíduos em seus ofícios particulares tornaria cada um mais independente dos demais enquanto produtor, mas, por outro lado, mais dependente deles enquanto consumidor, de modo que a divisão do trabalho e o intercâmbio de mercadorias seriam aspectos distintos e complementares de um processo integrador, garantindo e até mesmo promovendo o desenvolvimento da individualidade. Este desenvolvimento, por seu turno, permitiria uma movimentação cada vez mais livre dos recursos entre os diversos ramos da economia, conforme houvesse vantagem ou desvantagem em cada um. Daí a formulação por Adam Smith do famoso teorema da "mão invisivel", afirmando que as vantagens e desvantagens nos ramos específicos se compensariam na economia como um todo na qual não haveria excesso de produção nem crises gerais ${ }^{10}$.
\end{abstract}

Tanto em Hegel como em Adam Smith, a separação dos indivíduos até pode ser identificada como uma cisão, posto que só há separação havendo também uma união fundamental. No entanto, ambos vêem o mercado (ou a sociedade civil) ${ }^{11}$ como a mediação que resolve as contradições, promovendo o equilíbrio. Tal visão do mercado como mediação que soluciona as contradições é - como vimos no capítulo anterior -

\footnotetext{
${ }^{9}$ Hegel, The Philosophy of Right, p. 13 apud Mészáros, 2002, p. 65.

${ }^{10}$ Grespan, 1998, p. 49.

${ }^{11}$ Vale aqui uma ressalva, apontada por César R. S. Santos, qual seja, a de que ao contrário de Adam Smith, Hegel não identifica a sociedade civil diretamente ao Estado, sendo esta, inclusive, uma importante crítica do filósofo aos economistas políticos.
} 
justamente aquela criticada por Ellen Wood. Segundo as idéias desta Autora, a especificidade da propriedade propriamente capitalista é que a sua reprodução é mediada pelo mercado. Mas esta mediação não é um conjunto de possibilidades e sim um conjunto de coações às quais todos passam a se submeter, posto que o mercado põe as suas condições, nem sempre realizáveis, para realizar a re-unificação entre os momentos do capital. O não cumprimento de tais condições resulta na manifestação concreta da crise, uma vez que "a cisão aparente, a autonomia, é só manifestação de seu oposto, da relação fundamental. O decisivo, porém, [na manifestação da cisão como crise] é que essa relação atue separando, e não simplesmente unindo, como era de se esperar"12.

Ao contrário do idealismo alemão e da economia política clássica, que "adotaram o ponto de vista do capital", o marxismo identifica nesta separação a essência da contradição que caracteriza o capital e, ao fazê-lo, constrói uma teoria crítica em relação à socialização capitalista. Uma teoria que pretende promover uma reunificação dos sentidos originais de uma crítica subjetiva e uma crise objetiva. Da mesma forma como crítica e crise originalmente caracterizavam, como vimos, uma situação crítica que exige uma resolução prática, para Marx, "a crítica arrancou as flores imaginárias dos grilhões, não para que o homem os suporte sem fantasia ou consolo, mas para que lance fora os grilhões para que a flor viva brote" 13 .

\footnotetext{
${ }^{12}$ Grespan, 2004, p. 180.

${ }^{13}$ Marx, 2005, p. 146.
} 


\section{3 - O capital como movimento: a separação e a abstração da riqueza}

O trabalho, nessa sociedade, tornou-se, não somente no plano das categorias, mas na própria realidade, um meio de criar riqueza em geral, separando-se, enquanto determinação, dos indivíduos particulares.

Karl Marx, Introdução à Crítica da Economia Política

Se por um lado no capítulo anterior já foi destacada a importância da relação dos conceitos de crítica e crise com a noção de separação, por outro, a anunciada cisão própria do capital ainda não foi demonstrada, permanecendo indicada de forma um tanto abstrata. O objetivo do presente capítulo é, justamente, apresentar esta cisão numa formulação mais próxima da de Marx e dos marxistas aqui considerados.

A cisão fundamental que caracteriza o capital - e que está diretamente ligada ao conceito de crise - é a separação entre a produção e a realização da riqueza. Mesmo porque produção e realização têm, dentro da lógica do capital, significados específicos. A produção entendida enquanto produção de coisas não é, no capitalismo, imediatamente, produção de riqueza. Esta condição distingue o capitalismo de outros modos de produção. Em situações nas quais a riqueza era idêntica a um conjunto de objetos, o trabalho de cada indivíduo podia ser a determinação direta da produção da riqueza. Mesmo que as condições técnicas não permitissem um nível maior de produtividade, uma capacidade maior de transformação da natureza, essas limitações eram intrínsecas ao processo de trabalho. Ao contrário, na sociedade capitalista o trabalho não é imediatamente determinante da riqueza, visto que a produção de coisas também não é imediatamente produção de riqueza. Para nomear desde já esta distinção do capitalismo em relação a outras formas de reprodução social vou me referir a ela como uma abstração da riqueza, a qual será, a seguir, demonstrada em vários de seus níveis ${ }^{1}$.

\footnotetext{
${ }^{1}$ É importante destacar que me refiro a uma separação entre produção e realização e não entre produção e consumo. Como põe Belluzzo (1987, p. 106) "seria ocioso escrever três volumes [de $O$ Capital] para demonstrar que o capitalismo se funda na separação entre produção e consumo, característica, aliás, comum a outros modos de produção. É preciso, sim, explicar como esta separação se exprime na dinâmica capitalista." Assim sendo, é mais interessante pensar esta separação entre produção e realização à qual me refiro como uma cisão no processo de produção de riqueza e não como uma simples apropriação da produção de uns por outros, característica de qualquer sociedade com divisão social do trabalho e estratificação.
} 
Um bom começo para nos referirmos ao processo de abstração da riqueza é a identificação da cisão fundamental da mercadoria - a separação entre o valor e o valor de uso. Para não reproduzir detalhadamente a argumentação já bem divulgada - e mesmo assim nem sempre bem compreendida - de Marx é interessante já apontar diretamente para o fato de que a mesma separação entre o valor e o valor de uso se pode verificar na separação entre o trabalho abstrato e o trabalho concreto, posto que são elementos diretamente ligados. O trabalho concreto é o trabalho que produz valor de uso, a característica física da mercadoria e o trabalho abstrato é aquele que produz o valor, característica propriamente social da mercadoria. No entanto, é preciso notar que estas separações não se realizam enquanto separações. $O$ valor e o valor de uso não são elementos absolutamente separáveis, assim como não o são o trabalho abstrato e o trabalho concreto. Em ambos os casos o que temos é uma cisão interna à mercadoria e ao trabalho que produz mercadorias. Por ser interna esta cisão constitui uma contradição. Nesta contradição encontramos o impulso a um movimento que procurarei demonstrar.

Consideremos, como parâmetro inicial da análise [que deverá ser posteriormente negado], que o trabalho concreto é o trabalho de cada indivíduo que produz mercadorias. Por meio de sua atividade corporal o produtor transforma materiais diversos imprimindolhes uma certa forma, uma certa condição física que garante que este produto tenha um valor de uso, isto é, uma utilidade, o que lhe é fundamental para que possa ser socialmente reconhecido como uma mercadoria. Afinal de contas as mercadorias são coisas feitas para serem vendidas, portanto para que alguém as compre elas têm de satisfazer alguma necessidade "seja do estômago, seja da fantasia".

Mas então já surge um detalhe importante a ser considerado. Se a mercadoria é algo feito para ser vendido, o seu valor de uso é uma condição para a venda e não para o uso de quem a produziu. A mercadoria só é útil, para quem a produziu, enquanto objeto de troca, posto que não interessa ao seu produtor permanecer com ela, mas sim trocá-la. Com isto já alcançamos o primeiro sinal - mesmo que ainda não tão claro - de abstração da riqueza, uma vez que a produção de uma mercadoria não é imediatamente produção de riqueza para seu produtor. Nos termos em que estamos nos baseando a mercadoria só se transforma em riqueza propriamente, isto é, em algo útil para o seu produtor após este ter conseguido trocá-la por outra mercadoria. Enquanto não se efetivar a troca a mercadoria é para seu produtor apenas potencialmente riqueza. Ou seja, entre a produção e a realização da riqueza se encontra a troca. A troca é a mediação da produção de riqueza no capitalismo, 
ou seja, "a troca é o nexo fundamental que articula os produtores independentes e define a natureza de suas relações de produção"

E se o que interessa ao produtor é efetivar a troca com outras mercadorias, para ele a utilidade de sua mercadoria é o valor que ela tem na troca com as outras, isto é, o seu valor de troca. Na troca entre duas mercadorias o valor de uso de uma só interessa ao produtor da outra e não pode ser unidade de medida na determinação das quantidades a serem trocadas. Isto posto, a troca leva à abstração - agora já mais clara - dos valores-deuso, isto é, sua desconsideração no momento do intercâmbio das mercadorias, no qual, só o valor de troca interessa.

Mas esta abstração não é simplesmente uma abstração mental - apesar de não deixar de sê-lo - realizada pelos trocadores de mercadorias no momento da troca. E não o é por vários motivos. Para começar porque se a utilidade de uma mercadoria para seu produtor é o valor de troca que ela representa, enquanto valor de uso esta mesma mercadoria não realiza, imediatamente, os objetivos de seu produtor e, portanto, a mercadoria enquanto valor de uso deve ser eliminada das mãos de seu produtor por meio da troca com o dinheiro, o que significa a negação do valor de uso e sua substituição por puro valor de troca, isto é, dinheiro. Para explicitar melhor esta relação vejamos um pouco do caminho percorrido por Marx para decifrar o "enigma do dinheiro".

Em $\mathrm{O} \mathrm{Capital}^{3}$, Marx analisa a forma do valor com o objetivo de expressar a gênese do dinheiro. Como observa Fausto (1987, p. 154) a gênese do dinheiro é a pré-história (lógica) do dinheiro, isto é, a dedução da forma dinheiro. Para realizar este objetivo Marx passa por três formas do valor até chegar na forma do dinheiro. Estas três formas são a forma simples do valor (I), a forma total ou desdobrada do valor (II) e a forma geral do valor (III). Na primeira é analisada a troca entre duas mercadorias, na segunda entre uma mercadoria e todas as outras e na terceira entre as mercadorias e o equivalente geral. Neste percurso são analisados os papéis das mercadorias enquanto forma relativa de valor e forma equivalente de valor. $\mathrm{O}$ importante é perceber como estes papéis vão se alterando nas formas I, II e III.

Na forma I (simples) a troca entre duas mercadorias é posta como uma relação de valor. Uma delas, a mercadoria A, por exemplo, representa a forma relativa de valor,

\footnotetext{
${ }^{2}$ Belluzzo, 1987, p. 87. (grifos meus)

${ }^{3}$ Cf. Marx, 1988, páginas 53 a 70.
} 
enquanto a mercadoria $\mathrm{B}$ representa a forma equivalente. A relação entre as duas se dá no sentido de que a mercadoria A (forma relativa) tem seu valor expresso na mercadoria $\mathrm{B}$ (forma equivalente), por exemplo 1 mercadoria A vale 2 mercadorias $\mathrm{B}$. É nesta relação de valor que as mercadorias revelam-se como objetos de valor ${ }^{4}$. Para serem trocadas, antes mesmo de se definir a proporção em que ambas equivalem é preciso definir as duas como expressões quantitativamente diferentes de substâncias qualitativamente iguais, uma vez que "grandezas de coisas diferentes tornam-se quantitativamente comparáveis só depois de reduzidas à mesma unidade" $"$. Esta unidade é o valor. Mas se tanto a mercadoria A como a mercadoria B têm valor - como foi demonstrado na relação entre elas -, por que este valor só é expressado na relação? Justamente porque a forma valor é a expressão da produção de mercadorias enquanto coisas produzidas para serem trocadas. Ou, como se pode verificar nesta formulação de Belluzzo,

É a tensão permanente entre o caráter mediatamente social $e$ diretamente privado da produção na sociedade mercantil simples que imprime a forma valor aos produtos do trabalho. Isto é, nesta sociedade o produto do trabalho só pode subsistir como valor (capacidade de adquirir outros produtos), e o valor, por isso mesmo, só pode manifestar-se como valor de troca ${ }^{6}$.

A mercadoria A é produto do trabalho humano e, por isso, deve ter valor, posto que se pressupõe que o trabalho é a substância do valor. No entanto, o valor não é algo intrínseco a qualquer produto do trabalho humano, ao contrário, ele é próprio do trabalho humano que produz mercadorias. E o que a mercadoria tem que outros produtos do trabalho humano não têm? A mercadoria é produzida para ser trocada - nesta constatação já está a resposta. O valor só pode ser expresso numa relação entre duas mercadorias porque o valor é a capacidade que a mercadoria tem de ser trocada com outra mercadoria. É por isso que a forma de valor da mercadoria A é a forma relativa e não a "forma absoluta", isto é, ela é relativa no sentido de que ela não pode expressar o seu valor por si própria. Ela só tem valor para ser trocada com outra mercadoria e é somente nesta troca que seu valor poderá ser expresso - expresso necessariamente enquanto valor de troca. É aí

\footnotetext{
${ }^{4}$ Como observa Fausto (1987, p. 154), “O que se analisa quando se analisa a forma (simples) do valor é propriamente a expressão do valor", ou ainda, um pouco mais à frente, "A expressão do valor ela própria está na relação entre as duas mercadorias".

${ }^{5}$ Marx, 1988, Vol. 1, p. 55.

${ }^{6}$ Belluzzo, 1987, p. 87.
} 
que entra a mercadoria $\mathrm{B}$, com sua forma equivalente, servindo, portanto, como medida do valor de A.

Mas o valor de em A só pode ser medido pela mercadoria B por ser esta também portadora de valor, isto é, por ser esta igualmente produto do trabalho humano. Encontra-se então uma dificuldade - se a mercadoria B serve como forma de medir a mercadoria A e esta medida é a medida do valor de A, afinal, em termos de quê esse valor de A será expresso?

Ele não poderá ser expresso diretamente em termos de valor, com o que voltaríamos ao mesmo problema de que uma mercadoria não pode expressar imediatamente o valor. Quando dizemos que 1 mercadoria A vale 2 mercadorias B, a medida do valor de A é B, mas não o valor expresso em B (o qual só poderia ser expresso se B estivesse sendo tomada como a forma relativa e A como forma equivalente), mas sim duas unidades da mercadoria B. O corpo de B passou a ser a medida do valor de A, isto é, o valor de uso de B é a medida do valor de A. Portanto, na forma simples do valor, a mercadoria que assume a forma de equivalente simples tem no seu valor de uso e, portanto, no trabalho concreto que produziu este valor de uso a representação imediata da riqueza social, do trabalho humano em geral.

Mas isso ocorre, ainda, na forma simples do valor, caracterizada pela existência de apenas duas mercadorias. Neste caso, o nível de abstração da riqueza ainda é limitado, posto que o valor de uso da mercadoria $\mathrm{B}$ é representante direto da riqueza, isto é, o trabalho concreto que o produziu aparece (neste nível da apresentação) como determinante direto da riqueza. Não há a mediação do processo de troca para que este trabalho particular se ponha como trabalho social, ele é imediatamente social.

Para além da forma simples de valor está, na apresentação de Marx, a forma desdobrada do valor. Nesta a troca não se dá mais apenas entre duas mercadorias (1 A vale $2 \mathrm{~B}$ ), mas sim entre a mercadoria A e inúmeras outras mercadorias (1A vale $2 \mathrm{~B}$ ou $3 \mathrm{C}$ ou 0,5D ou 8E...) numa condição em que o processo de troca se generalizou, estando instituído o mundo da mercadoria. Na forma desdobrada do valor, o valor da mercadoria $\mathrm{A}$ não precisa mais se espelhar no valor de uso da mercadoria $B$, necessariamente. Ele pode ser medido pelo valor de uso de qualquer outra mercadoria. Nestas condições o valor de uso de cada uma das mercadorias é negado num nível acima do que já o era na relação entre duas mercadorias. Segundo a formulação de Marx; 
Por meio de sua forma valor, o linho [é o exemplo de Marx que no meu exemplo deve ser visto como a mercadoria A] se encontra portanto agora também em relação social não mais apenas com outra espécie individual de mercadoria, mas sim com o mundo das mercadorias. Como mercadoria, ele é cidadão deste mundo. Ao mesmo tempo, depreende-se da interminável série de suas expressões que é indiferente ao valor mercantil a forma específica do valor de uso na qual ele se manifesta ${ }^{7}$.

O trabalho concreto que produz o valor de uso da mercadoria $\mathrm{B}$ não é mais o representante direto da riqueza social. Ele só o é ao se colocar como "cidadão do mundo das mercadorias", isto é, a determinação não é direta porque já se pode verificar que existem certas condições para que ele represente valor, condições que estão para além dele. A manifestação concreta do conjunto destas condições é justamente o mundo das mercadorias com o qual a mercadoria particular se defronta. Nestas condições a troca não é mais uma exceção e sim a regra. Em tal situação, já "transparece imediatamente um fundamento essencialmente diferente da manifestação casual e que a determina" ${ }^{\text {" }}$.

Mas a forma desdobrada ainda não apresenta toda a abstração que caracteriza propriamente a forma dinheiro. Sua insuficiência pode ser verificada na seguinte passagem de Marx.

Como aqui a forma natural de cada espécie particular é uma forma equivalente particular ao lado de inúmeras outras formas equivalentes particulares, existem, em geral, apenas formas equivalentes limitadas, das quais cada uma exclui a outra. Do mesmo modo, é a espécie de trabalho determinada, concreta, útil, contida em cada mercadoria equivalente particular, apenas forma de manifestação particular portanto não exaustiva - do trabalho humano. Esse possui, em verdade, sua forma de manifestação completa ou total no ciclo inteiro daquelas formas particulares de manifestação. Porém, assim ele não possui nenhuma forma de manifestação unitária ${ }^{9}$.

O que destaca esta insuficiência é justamente que nesta cadeia infinita de trocas cada uma das mercadorias ainda assume, ao mesmo tempo, a forma relativa e a forma equivalente do valor. Sempre que uma mercadoria assume a forma equivalente do valor

\footnotetext{
${ }^{7}$ Marx, 1988, p.64

${ }^{8}$ Marx, 1988, p.65 (grifos meus).

${ }^{9}$ Marx, 1988, p.65
} 
isto significa que o trabalho concreto que a produziu continua se pondo diretamente como trabalho social, apesar de não se pôr mais de forma absoluta devido à existência de inúmeros outros trabalhos concretos que também assumem a forma de equivalente. Mesmo assim, o trabalho humano em geral (que é a riqueza abstrata) só se manifesta por meio dos inúmeros trabalhos concretos, não apresentando autonomia em relação a eles.

Mas como coloca Marx, para explicar a passagem da forma II (desdobrada) para a forma III (geral), se ao invés de pegarmos uma mercadoria como forma relativa e a compararmos com várias outras como formas equivalentes $(1 \mathrm{~A}$ vale $2 \mathrm{~B}$ ou $3 \mathrm{C}$ ou $0,5 \mathrm{D}$ ou $8 \mathrm{E} . .$.$) invertermos o raciocínio, colocando inúmeras mercadorias como formas relativas e$ apenas uma como forma equivalente (2B ou $3 \mathrm{C}$ ou $0,5 \mathrm{D}$ ou $8 \mathrm{E} \ldots$...valem $1 \mathrm{~A}$ ), nos aproximamos da forma equivalente geral. Nesta passagem o que ocorreu foi que todas as mercadorias, com exceção de uma, passaram a assumir a forma relativa de valor, isto é, todas só podem expressar o seu valor em uma que assumiu a forma equivalente - o equivalente geral, ou, o dinheiro. Neste caso,

todas as demais mercadorias expressam seu valor no mesmo equivalente e cada nova espécie de mercadoria que aparece tem de fazer o mesmo. Evidencia-se com isso, que a objetividade do valor das mercadorias, por ser a mera "existência social" dessas coisas, somente pode ser expressa por sua relação social por todos os lados, por isso, tem de ser uma forma socialmente válida ${ }^{10}$.

Para apreender a abstração da riqueza que ocorre nesta passagem, retomemos, sinteticamente, o argumento do início. Na forma simples do valor temos a troca entre duas mercadorias. Esta troca é posta por Marx como singular e acidental, o que nos leva a pressupor que o produtor da mercadoria A quer trocá-la pela mercadoria $\mathrm{B}$, mas que o seu trabalho não se resume à produção de A. Isto é, sua reprodução não depende exclusivamente do quanto de B ele consegue produzindo A. Por isso, esta forma do valor é ainda singular e não universal. No entanto, a mercadoria $\mathrm{B}$ já funciona como equivalente, no sentido de que ela mede o trabalho do produtor de A. A eficiência de seu trabalho ao produzir A se revelará quando se estabelecer a troca por B.

$\mathrm{Na}$ forma desdobrada do valor, cada mercadoria pode ser trocada por todas as outras. Neste caso, a troca parece ser posta, ainda, como um conjunto de possibilidades,

\footnotetext{
${ }^{10}$ Marx, 1988, p. 67. (grifos meus)
} 
uma vez que cada mercadoria traz em si a capacidade de expressar diretamente o valor, o trabalho social, isto é, a riqueza abstrata. Apenas quando passamos à forma geral do valor é que o valor realmente se põe como algo autônomo no qual a troca se torna um conjunto de coações e não mais de possibilidades, posto que é a partir de então que todos os trabalhos passam a assumir a condição da forma valor relativa, que só pode se expressar no equivalente geral que é o dinheiro. Esta generalização da forma valor relativa é que gera o equivalente universal, o dinheiro. Ou como põe Marx, "o desenvolvimento da forma equivalente é apenas expressão e resultado do desenvolvimento da forma relativa"11.

O que isto significa é que o valor de uso de todas as mercadorias passa a ser negado pelo valor de troca em estado puro, representado pelo dinheiro. Esta é uma abstração real e não apenas mental do valor-de-uso no sentido de que toda a produção de valores-de-uso, isto é, todos os trabalhos concretos passam a depender de sua troca por dinheiro para se efetivarem enquanto riqueza.

A identificação do dinheiro como uma abstração reafirma que a produção de riqueza no capitalismo é intermediada pela troca. No entanto esta intermediação não se dá apenas no sentido de que enquanto o produtor não trocar a mercadoria que produziu ela não se transforma, efetivamente, em riqueza. Para além disso, a produção passa a ser determinada pelas condições da troca, ou, na formulação de Belluzzo, "o valor de troca de cada mercadoria não está estabelecido de antemão pelo esforço de cada produtor, mas é determinado posteriormente às flutuações, marchas e contramarchas do processo de troca" ${ }^{\prime 2}$. Após vermos como se dá este processo de intermediação da produção pela troca, com um nível de detalhamento que, espero, seja compatível com as pretensões do presente trabalho, deverão ficar mais claras as afirmações feitas anteriormente sobre o papel do mercado como um conjunto de coações e não de possibilidades.

Para começar vou explicitar melhor o nível de abstração no qual nos encontramos. As mercadorias são produzidas para serem trocadas. A proporção na qual as mercadorias são trocadas só pode ser estabelecida abstraindo-se o valor de uso, isto é, as diferenças qualitativas entre elas para se chegar naquilo que têm de comum e de comensurável, ou seja, para se chegar à sua substância de valor. Substância essa que se manifesta como valor de troca no momento do intercâmbio. A substância de valor das mercadorias, sua substância mensurável é, justamente, o trabalho. Mas não qualquer trabalho e sim o

\footnotetext{
${ }^{11}$ Marx, 1988, p. 67.

${ }^{12}$ Belluzzo, 1987, p. 80.
} 
trabalho que produz mercadorias. Este tipo de trabalho tem, como diz Marx, um duplo caráter. Por um lado é trabalho concreto, por outro é trabalho abstrato. Sobre o trabalho concreto já foi afirmado há pouco que ele é o responsável pela criação dos valores-de-uso das mercadorias. Mas como já vimos também que na troca o valor de uso é abstraído, deve ficar claro que o mesmo ocorre com o trabalho concreto. Ele sofre uma abstração. Aliás uma dupla abstração ${ }^{13}$. Por um lado qualitativa, pois suas especificidades são desconsideradas para que seja mensurável como tempo de trabalho. Por outro lado, quantitativa, posto que este tempo não é o tempo que realmente o trabalhador levou para fazer a mercadoria, mas sim o tempo de trabalho socialmente necessário. $\mathrm{O}$ tempo de trabalho necessário para se fazer uma determinada mercadoria nas condições normais de tecnologia, de destreza dos trabalhadores e assim por diante. Condições tais que são uma manifestação concreta (no sentido de uma expressão das múltiplas determinações) das relações de mercado. Isto é, o trabalho realizado pelo produtor sobre a sua mercadoria só se tornará riqueza se esta mercadoria for trocada por outra e esta troca se dará não de acordo com os padrões qualitativos ou quantitativos definidos pelo produtor mas sim pelo mercado. Daí afirmarmos que a produção e a realização da riqueza são mediadas pelas relações de mercado especificamente capitalistas.

Mas ainda é preciso prosseguir no percurso da apresentação da abstração. Entendendo a apresentação de Marx como um caminhar do abstrato ao concreto, demonstrando a abstração das relações sociais, poderíamos dizer - sem medo de esbarrar num vício de linguagem - que ainda estamos num nível muito abstrato da apresentação da abstração. Isto é, ainda estamos desconsiderando uma série de elementos que caracterizam as relações econômicas capitalistas. Na verdade estamos ainda muito próximos dos pressupostos da economia política clássica, criticada por Marx. Isto significa, basicamente, que ainda estamos considerando que as relações de produção e intercâmbio capitalistas são fundamentadas na troca de equivalentes. É interessante, inclusive, destacar que as análises feitas até este momento se referem, apenas, às temáticas da seção I de $O$ Capital, isto é à mercadoria e ao dinheiro.

Como já mencionado, no entanto, os pressupostos da seção I são negados no restante da obra de Marx e postos como momentos de uma totalidade dominada pelo capital. O sentido desta negação é, portanto, a demonstração do processo de efetivação do capital, que envolve, por sua vez, o fetichismo. A demonstração de tal processo é um longo

\footnotetext{
${ }^{13}$ Cf. Fausto, 1987, p. 92.
} 
percurso que envolve os livros I, II e III. Como já descrito, enquanto o livro I se dedica a analisar o processo de produção, o livro II se concentra no processo de circulação e o III procura pôr as duas esferas anteriores em choque no processo global da produção capitalista.

Na separação entre produção e circulação, a primeira é determinada pela relação entre o processo de trabalho e o processo de valorização, enquanto a última é determinada pelas metamorfoses da mercadoria. Tanto nas duas esferas de forma separada como na união entre elas própria do livro III é possível se verificar a especificidade da mais-valia enquanto forma de extração de trabalho excedente. Para definir melhor, desde já, tal especificidade, poderíamos nos referir à mais-valia como um trabalho excedente cuja realização não é totalmente determinada no processo produtivo propriamente dito, mas, ao contrário, é mediada pelas condições da troca especificamente capitalista.

Na esfera da produção, como veremos a seguir, a produção de mercadorias não é, imediatamente, produção de mais-valia, ao contrário, a produção de mais-valia depende das relações que se estabelecem entre o processo de trabalho - isto é, a produção propriamente dita - e o processo de valorização - a produção da mais-valia. Destacando-se que tais relações não são constantes e não são determináveis diretamente no processo produtivo. Já, na esfera da circulação - como também se verá em maiores detalhes mais adiante - a mais-valia que foi produzida na esfera da produção tem de se realizar por meio das metamorfoses da mercadoria, isto é, por meio das necessárias mudanças de forma entre mercadoria e dinheiro. Estas metamorfoses, no entanto, são condicionadas pela forma da troca especificamente capitalista. Já no conjunto contraditório entre a produção e a circulação - ao qual podemos nos referir como a produção e a realização da mais-valia a transformação da mais-valia em lucro e dos valores em preços de produção levam o processo de abstração da riqueza à sua forma mais concreta. A seguir procurarei reproduzir estes momentos do ponto de vista da abstração da riqueza como a defini há pouco. 


\section{1 - A produção de mais-valia como produção de riqueza abstrata}

Encerrada a seção I - na qual o capitalismo ainda aparece como fundado na troca de equivalentes - Marx dá início á demonstração do fundamento do capital por meio da análise da circulação do dinheiro, na qual este se revela como capital. Para se compreender esta "revelação" é preciso destacar a diferença entre a circulação simples de mercadorias e a circulação do dinheiro. A primeira pode ser representada pela fórmula M-D-M, segundo a qual o produtor de uma mercadoria a troca por dinheiro para que desta maneira possa ter acesso a outra mercadoria que ele não produz. Já a última representa-se na fórmula D-MD' (considerando-se que D' significa o D valorizado), ou seja, dinheiro sendo transformado em mercadoria para, desta forma, transformar-se em mais dinheiro. $\mathrm{Na}$ circulação simples de mercadorias as duas mercadorias do começo e do final do processo são qualitativamente diferentes. Esta diferença qualitativa é a causa da troca. O produtor abre mão de um valor de uso específico para ter acesso a outro. No caso da circulação do dinheiro, tanto no início do processo como no final tem-se algo de mesma qualidade, isto é, dinheiro. Desta forma, a diferença só pode ser quantitativa. E só esta diferença quantitativa é que pode ser a causa de se pôr o dinheiro para circular, evitando-se o entesouramento. Desta forma, o próprio fundamento da circulação do dinheiro é a valorização.

Aí é que começa a ficar difícil de aceitar imediatamente a idéia de que as mercadorias se trocam pelos seus valores e que esses valores são equivalentes. O problema é, justamente, a diferença quantitativa entre o início e o final da circulação do capital. Como pode haver tal diferença, isto é, como haver no final mais valor do que havia no início partindo-se da idéia de que as mercadorias se trocam pelos seus valores? Se assim o fosse de onde surgiria um valor que não existia antes?

Pode-se imaginar que esta diferença não é, necessariamente, própria do capitalismo, mas sim de qualquer operação comercial, desde a antiguidade clássica ou até antes dela. Afinal, fazer comércio não é, justamente, comprar mais barato e vender mais caro? Sim, mas a questão a se colocar neste caso é sobre o que permite ao comerciante comprar mais barato para vender mais caro. Mais à frente farei uma reflexão mais ampla sobre a questão do comércio e sobre a polêmica acerca da atividade comercial criar ou não valor. Mas, por enquanto, é preciso apontar já uma breve resposta. O que permite ao comerciante comprar mais barato e vender mais caro em uma condição social que não seja propriamente capitalista, é algum fator de monopólio (legal, espacial, de escala ou de outro tipo) que leva o consumidor a ter de comprar daquele comerciante e não poder comprar de quem o 
próprio comerciante comprou. De qualquer forma, como vimos o valor das mercadorias vem do trabalho abstrato que as gera, de forma que o processo de valorização deve ser buscado na produção e não na venda.

Neste caso o percurso D-M-D' não se refere à compra de uma mercadoria por um preço e a venda desta mesma mercadoria por um preço mais elevado. $\mathrm{O} \mathrm{M}$ se refere aos fatores da produção de mercadorias, isto é, matérias-primas, meios de produção e força de trabalho, que são comprados pelo capitalista e transformados na mercadoria que será vendida com mais valor do que o capitalista desembolsou para adquirir os fatores da produção.

Os fatores de produção são divididos em dois grupos, o trabalho vivo e o trabalho morto, ou, dito de outra forma, o capital variável e o capital constante. Trabalho vivo e capital variável são duas formas de se referir à força de trabalho, enquanto trabalho morto e capital constante se referem aos meios de produção e às matérias-primas. Esta classificação tem como objetivo ressaltar que as matérias-primas e os meios de produção não acrescentam à mercadoria produzida mais valor do que o já presente neles mesmos, ao contrário da força de trabalho que tem a capacidade de criar mais valor, isto é, mais-valia. É só através da mais-valia que o processo de valorização é possível. A mais-valia é, justamente, um valor a mais, que não existia no início do processo e está presente no final.

Mas a mais-valia, isto é importante de se notar, não é um excedente como outro qualquer. Não é uma forma de trabalho excedente igual às que existiram em outros modos de produção. O fator distintivo da mais-valia é que ela é uma forma de extração de excedente diretamente dependente da troca de mercadorias, enquanto a extração do trabalho excedente do escravo ou do servo, por exemplo, depende diretamente da coerção física direta ${ }^{14}$.

Inclusive só é possível a generalização do procedimento de extração de mais-valia a partir de condições histórico-sociais bastante específicas, notadamente, a partir da separação entre produtores diretos e os meios de produção, processo ao qual Marx se referiu como acumulação primitiva ou original. O resultado imediato deste processo é que

\footnotetext{
${ }^{14}$ Com isso não estou afirmando que dentro do modo de produção capitalista não possam existir outras formas de extração de excedente. Não só reconheço que elas existem como também entendo que sua existência tenha sido e de certa forma continue sendo fundamental para a existência do capitalismo. Mas a discussão sobre as relações entre formas não-capitalistas e outras propriamente capitalistas é assunto do capítulo 4. Por enquanto, para o bem da argumentação, é importante, a meu ver fazer a distinção entre estas formas.
} 
o único meio de sobrevivência para aqueles que não têm acesso direto aos meios de produção passa a ser, justamente, a venda da sua força de trabalho. A acumulação primitiva transformou a capacidade de trabalhar em força de trabalho, ou seja, numa mercadoria.

Sendo uma mercadoria, a força de trabalho pode ser trocada no mercado por outras mercadorias. E, do ponto de vista do seu possuidor original - o produtor direto - ela não só pode como deve, posto que é esta a única forma desse produtor ter acesso às mercadorias de que necessita para sobreviver. Na troca entre a mercadoria força de trabalho e as outras mercadorias necessárias à reprodução do trabalhador valem os princípios da troca de equivalentes, isto é, a mercadoria força de trabalho será trocada de acordo com seu valorde-troca, sendo este definido como o tempo de trabalho socialmente necessário para produzi-la ${ }^{15}$. Em troca do salário o trabalhador entrega a sua força de trabalho, por um tempo determinado, ao capitalista.

Mas se o salário representa o valor de troca da força de trabalho, qual é o seu valor de uso? Ele é, justamente, a capacidade de produzir mais valor, isto é, mais-valia para seu comprador. Mas note-se, é apenas a possibilidade. Para que esta possibilidade se torne efetividade será preciso cumprir as exigências do processo de circulação do capital, isto é, D-M-D'. É preciso, então, esclarecer que em Marx a circulação do capital tem um duplo sentido $^{16}$. Num sentido restrito pode ser apenas o processo de compra e venda das mercadorias, excluindo-se o processo de produção. No sentido amplo é o percurso completo de realização do capital, ou de sua valorização, o qual necessariamente inclui os três momentos da equação D-M-D', entre os quais se acham a compra dos fatores da produção, o processo produtivo propriamente dito e a venda das mercadorias produzidas.

Como o foco, no momento, é apenas a esfera da produção, o primeiro passo para dar continuidade à analise é pressupormos que os fatores da produção estão disponíveis para que o capitalista os compre e os utilize para a produção de suas mercadorias, assim como pressupor que as mercadorias serão vendidas pelos seus valores. O segundo passo é reconhecer que entra no processo de produção menos valor do que dele sai, sem o que não

\footnotetext{
${ }^{15}$ A meu ver é mais interessante o uso do termo reprodução do que de termos como sobrevivência, por exemplo. O termo reprodução permite que consideremos que o quanto o trabalhador receberá será a quantia compatível com as necessidades e possibilidades estabelecidas pelo contexto sócio-político-cultural no qual ele está inserido, incluindo-se aí as condições ou limitações de luta por melhores salários que a ele se apresentam.

${ }^{16}$ Cf. Grespan (1998, p.154) e Harvey (1990, p. 93)
} 
poderia haver processo de valorização. O terceiro, e mais importante passo, é identificar como se cria este valor a mais. Mas isso já foi afirmado acima, ele vem da força de trabalho, a qual tem como valor de uso a capacidade de gerar mais valor do que consumiu. No entanto, esta capacidade foi posta acima como possibilidade e agora é preciso demonstrar o porquê ela é apenas possibilidade e quais são as exigências postas para sua efetivação.

A capacidade de produzir mais valor do que consome vem de uma possível diferença temporal, qual seja, o tempo necessário para que o trabalhador - ao executar o processo de trabalho - produza o valor suficiente para pagar seu próprio salário pode ser diferente do tempo total de sua jornada de trabalho.

O processo de trabalho sob condições capitalistas é processo de produção de mercadorias e, desta forma, é processo de formação de valor. Como vimos o trabalho tem um duplo caráter, o de produzir um valor de uso, posto que é trabalho concreto e, ao mesmo tempo, o de produzir valor, posto que é trabalho abstrato. Supondo que um determinado processo de trabalho seja, efetivamente, processo de formação de valor - para o que, diga-se de passagem ele deve cumprir certas condições sociais ${ }^{17}$-, além da força de trabalho ter a capacidade de passar o valor já existente na matéria-prima e nos meios de produção para a nova mercadoria, enquanto trabalho concreto que é, ela tem, igualmente, a capacidade de passar para a nova mercadoria o seu próprio valor, posto que é - por seu duplo caráter - também trabalho abstrato. Enquanto trabalho concreto o que interessa da força de trabalho é que ela transforma meios de produção e matérias-primas específicos em valores-de-uso específicos e, por isso, transfere o valor dos primeiros para estes últimos. Enquanto trabalho abstrato, no entanto, a força de trabalho transfere para a mercadoria o seu próprio valor. $\mathrm{O}$ que determina esta transferência do seu próprio valor à mercadoria não é seu caráter útil, concreto, específico, mas apenas o seu caráter de trabalho humano em geral e, desta forma, a determinação da grandeza deste valor é, justamente, o fator tempo.

Com isso voltamos à discussão sobre a possível diferença temporal. Se por um lado, o trabalhador estará passando para as mercadorias o valor de sua força de trabalho

\footnotetext{
17 “Só duas condições têm de ser preenchidas. Primeiro o algodão e o fuso [matéria-prima e meio de produção] devem ter servido realmente à produção de um valor de uso. Devem ter se tornado em nosso caso fio. Que valor de uso o porta é indiferente ao valor, mas um valor de uso tem de portá-lo. Segundo, pressupõe-se que somente o tempo de trabalho necessário, sob certas condições sociais de produção foi aplicado". Marx, 1988, Vol. I, p.149.
} 
durante o tempo que estiver trabalhando (considerando que esteja cumprindo as condições sociais anteriormente apontadas), por outro, isto não significa que ele receberá todo este valor. Ele receberá seu salário, o qual se refere ao valor de troca de sua força de trabalho, o que, por sua vez, significa o quanto de valor tal força de trabalho necessita para se reproduzir. Se, e somente se, o tempo de trabalho referente ao seu salário for menor que o tempo de trabalho efetivamente transferido para as mercadorias põe-se uma diferença temporal, a qual produz o que se chama de mais-valia. Na formulação de Marx;

Se compararmos o processo de formação de valor com o processo de valorização, vemos que o processo de valorização não é nada mais que um processo de formação de valor prolongado além de certo ponto. Se este apenas dura até o ponto em que o valor da força de trabalho pago pelo capital é substituído por um novo equivalente, então é um processo simples de formação de valor. Se ultrapassa este ponto, torna-se processo de valorização ${ }^{18}$.

Daí que a mais-valia possa ser vista como o tempo de trabalho não pago ao trabalhador. Esta definição, porém, pode guardar uma certa má compreensão do processo e pode deixar escapar o caráter distinto da mais-valia como forma especificamente capitalista de extração do trabalho excedente. O que se deve destacar para manter-se esta compreensão é justamente o caráter de mera possibilidade da produção de mais-valia.

Nos termos da circulação simples de mercadorias (M-D-M) o trabalhador, ao ser contratado não está, imediatamente, entregando mais do recebe. Ele está recebendo o equivalente por sua força de trabalho ${ }^{19}$. Mas para que esta troca se transforme em processo de valorização é necessário que o tempo de trabalho ultrapasse o ponto em que o valor da força de trabalho pago pelo capital é substituído por um novo equivalente. A ocorrência ou não desta ultrapassagem depende da produtividade da força de trabalho a qual, por sua vez, está diretamente ligada à forma como o processo de trabalho se dá. Daí a afirmação feita anteriormente de que a produção da mais-valia depende das relações entre o processo de trabalho e o processo de valorização. Isto é, o processo de trabalho não é, imediatamente, processo de valorização. Para que o seja ele deve formar mais valor do que

\footnotetext{
${ }^{18}$ Marx, 1988, Vol. I, p. 154.

19 "A circunstância de que a conservação diária da força de trabalho custa somente meio dia de trabalho, apesar da força de trabalho poder operar, trabalhar, o dia inteiro; de que, então o valor que seu uso cria durante um dia é o dobro do seu valor diário, é uma sorte especial para o comprador [de força de trabalho], mas não por isso uma injustiça para o vendedor", Marx, 1988, Vol. I, p. 160.
} 
aquele referente ao salário do trabalhador. Quando esta condição é cumprida podemos afirmar que se está produzindo a mais-valia absoluta.

A mais-valia absoluta pode ser entendida, simplesmente, como o valor produzido no lapso de tempo além do tempo de trabalho socialmente necessário para produzir a própria força de trabalho. Enquanto se considera a produção de mais-valia apenas nos termos da mais-valia absoluta, diz-se que há uma subsunção apenas formal do trabalho no capital. Ou seja, há neste caso produção de mais-valia pelo simples fato de que o trabalhador vendeu sua força de trabalho ao capitalista e este controla, portanto, o resultado do processo de produção que envolve esta mesma força de trabalho. $\mathrm{O}$ aumento da massa de mais-valia, nestes termos, só pode se dar por meio de um aumento do período de trabalho. Aumenta-se o tempo de trabalho que excede o tempo de trabalho socialmente necessário para reprodução da força de trabalho, sendo que este último permanece constante.

Mas esta forma da produção de mais-valia é limitada. É limitada, em primeiro lugar, no sentido de que ela tem mesmo um limite absoluto. Não é possível se aumentar continuamente a massa de mais-valia aumentando-se o período de trabalho pois os trabalhadores não suportariam. Em segundo lugar, e principalmente, é limitada no sentido de não revelar a tendência intrínseca ao capital de se ampliar continuamente segundo limites próprios e não limites postos por algo exterior, que neste caso seria o tempo máximo da jornada de trabalho. Esta necessidade de auto-expansão está ligada à tendência do capital se efetivar enquanto capital, criando um modo de produção especificamente capitalista. Ou seja, está ligada à tendência do capital de se pôr como sujeito.

Dito simplesmente dessa forma, esta afirmação pode soar um tanto abstrata, já que não foram apresentados os mecanismos concretos da passagem do capital à condição de sujeito. Assim como ainda não foi esclarecida a posição aqui adotada sobre o significado de tal condição. Estes temas serão discutidos, mas por enquanto já se faz necessária uma breve reflexão sobre o assunto, a qual pode ser introduzida com o seguinte trecho;

O modo como as leis imanentes da produção capitalista aparecem no movimento externo dos capitais, como se impõe como leis coercitivas da concorrência e assim surgem na consciência do capitalista individual como motivos impulsionadores não é para ser apreciado agora, mas esclareçamos de antemão: uma análise científica da concorrência só é 
possivel depois de se compreender a natureza interna do capital, do mesmo modo que o movimento aparente dos corpos celestes somente é compreensivel para quem conhece seu movimento real, embora imperceptível aos sentidos ${ }^{20}$.

Considerar que existem leis imanentes do capitalismo que se apresentam de certo modo no movimento externo dos capitais, mesmo antes de demonstrar a relação deste mecanismo com as leis coercitivas da concorrência, é importante para não se perder um dos elementos do viés crítico do marxismo em relação ao capital. Este elemento é o fetichismo que está indicado nesta formulação por meio do desencontro sugerido entre a maneira como os capitalistas apreendem o fenômeno da concorrência e o seu fundamento propriamente dito. Desencontro, por sinal, comparado por Marx com aquele existente entre o movimento aparente dos corpos celestes e o seu movimento real.

Tal desencontro surge da condição do capitalista individual diante do capital enquanto forma de relação social. Desta condição se cria a impressão de que a concorrência é o fundamento do capital e não o contrário. Mas também, não é de se admirar que esta inversão ocorra, posto que é justamente contra a concorrência que o capitalista individual tem de agir para se reproduzir enquanto tal. A demonstração de que a concorrência não é propriamente o fundamento do capital mas sim sua forma de efetivação ficará para mais tarde. Mas, por enquanto, é preciso lançar mão da lógica da concorrência para demonstrar a necessidade da passagem da mais-valia absoluta à mais-valia relativa.

Como descrevi, a mais-valia absoluta é simplesmente o valor produzido no lapso de tempo que supera o tempo de trabalho socialmente necessário para a reprodução da força de trabalho. A única forma de ampliar a massa de mais-valia neste caso era aumentar este lapso de tempo por meio do aumento da jornada de trabalho. No caso da mais-valia relativa o aumento do dito lapso de tempo não se dá por meio da extensão da jornada de trabalho, mas sim através da diminuição do tempo de trabalho socialmente necessário para a reprodução da força de trabalho. Esta diminuição, por sua vez só pode ser promovida pelo aumento da produtividade do trabalho. Ou porque o próprio trabalhador consegue formar o valor referente ao seu salário com menos tempo de trabalho. Ou porque as mercadorias referentes às necessidades de reprodução da força de trabalho começam a ser produzidas com menos tempo de trabalho socialmente necessário. Como o aumento da produtividade do trabalho está ligado à formas de reorganização do processo produtivo e de inserção da

\footnotetext{
${ }^{20}$ Marx, 1998, Vol. 1, p. 240.
} 
maquinaria em tal processo, é evidente que ocorre um aumento generalizado da produtividade do trabalho, possibilitando os dois processos.

O interessante desta mudança é que o aumento da mais-valia deixa de ter como limite exterior a jornada de trabalho. Por isso dizemos que a produção da mais-valia relativa está ligada à subsunção real - e não mais apenas formal - do trabalho no capital. $\mathrm{O}$ próprio processo produtivo passa a ser organizado de forma a atender, diretamente, às exigências do capital, isto é, a maximização do lucro por meio da maximização da produtividade do trabalho. Neste sentido, podemos denominar o modo de produção que emerge desta mudança de modo de produção especificamente capitalista. Para discutirmos detalhes interessantes do caráter especificamente capitalista deste modo de produção vejamos o seguinte trecho de Marx;

No capítulo III $^{21}$ havíamos exposto pormenorizadamente como, com a produção da mais-valia relativa (para o capitalista individual, na medida em que toma a iniciativa, acicatado pela circunstância de o valor ser $=$ ao tempo de trabalho socialmente necessário que se objetivou no produto; estimulado pelo fato de que, por isso, por conseguinte, o valor individual do seu produto é mais baixo do que o seu valor social e de que, por isso, pode ser vendido acima do seu valor social) se modifica toda a forma do modo de produção (inclusivamente do ponto de vista tecnológico) e surge um modo de produção especificamente capitalista, sobre cuja base, e ao mesmo tempo que ele, se desenvolvem as relações de produção - correspondentes ao processo produtivo capitalista - entre os diversos agentes da produção e, em particular, entre os capitalistas e os assalariados ${ }^{22}$.

Comecemos observando o final do trecho, no qual Marx afirma que há uma mudança nas relações de produção entre os capitalistas e os operários. É claro que, pelo que foi dito anteriormente, esta mudança vai no sentido de estabelecer nestas relações de produção um caráter mais propriamente capitalista em relação ao que havia anteriormente. Sobre isso, em primeiro lugar, é interessante observar que o aumento da produtividade do trabalho propicia uma crescente eliminação do caráter de violência física direta no processo de exploração do trabalho. Não há como negar que o aumento da mais-valia absoluta por meio da extensão da jornada de trabalho guardava um caráter não-capitalista -

\footnotetext{
${ }^{21}$ Atualmente capítulos X e XI do livro 1, seção 4 de $O$ capital.

${ }^{22}$ Marx, 1985, p. 92.
} 
no sentido de se revelar mais facilmente como uma dominação extra-econômica - do que a ampliação da mais-valia relativa por meio da intensificação da produtividade do trabalho.

Em segundo lugar, é importante chamar a atenção para o fato de que esta minimização de condições de exploração extra-econômica na relação de exploração do trabalho pelo capital inclui, necessariamente, uma inversão segundo a qual as forças produtivas do trabalho - representadas pela cooperação, pela aplicação da maquinaria e dos conhecimentos científicos ao processo produtivo - passam a aparecer como força produtiva do capital. Este é, como se verá, o fetichismo do capital.

Mas o mais importante no trecho supracitado é um elemento que demonstra o caráter especificamente capitalista próprio da produção da mais-valia relativa, qual seja, a necessidade imposta aos capitalistas individuais pela lei coercitiva da concorrência de buscar esta forma de mais-valia. Esta necessidade é imposta pela relação entre o valor individual e o valor social de cada mercadoria, vejamos como isso ocorre.

Num primeiro momento um entre muitos capitais individuais produz uma determinada mercadoria cujo valor total é composto pelo valor vindo do capital constante e pelo valor vindo do capital variável em partes iguais. Metade de seu valor corresponde aos meios e produção e às matérias-primas e a outra à força de trabalho despendida para transformar estes meios de produção e matéria-prima na mercadoria final. Suponhamos que essa quantidade de força de trabalho contida na mercadoria seja de uma hora e que essa medida corresponda ao tempo de trabalho socialmente necessário, isto é, está de acordo com o padrão social.

Num segundo momento, este mesmo capital individual logra - seja por meio de uma reorganização do processo produtivo seja por meio da utilização de maquinaria duplicar a produtividade do trabalho. Com isso, o valor dos meios de produção e das matérias-primas convertido na mercadoria final - isto é o que se pressupõe - continua o mesmo, enquanto o valor da força de trabalho cai pela metade, posto que, agora, o trabalhador faz duas mercadorias em uma hora, sendo meia hora o valor incorporado a cada uma. Neste caso, o valor total da mercadoria unitária cai a $75 \%$ de seu valor original.

Considerando-se que os outros capitais individuais não aumentaram - ainda - a produtividade do trabalho em seus respectivos processos produtivos, aquele primeiro, que aumentou, tem uma grande vantagem, posto que o valor individual de sua mercadoria é 
mais baixo que o valor social desta mesma mercadoria. Com isso ele poderia vendê-la acima de seu valor individual conseguindo, assim, uma mais-valia extra. Mas como com o aumento da produtividade do trabalho ele passa a produzir não só mais rápido como também em maior quantidade é necessário dar vazão ao dobro de mercadorias que se produzia anteriormente, o que o leva a vender sua mercadoria acima de seu valor individual mas pouco abaixo do valor social. Produz-se, neste caso, um processo de concorrência pelo qual todos os outros capitais individuais deverão também aumentar a produtividade do trabalho em seus processos produtivos. Caso não o façam terão que arcar com a conseqüência de ver a massa de mais-valia diminuir até desaparecer. E por que tal coisa aconteceria?

Como se sabe "o verdadeiro valor de uma mercadoria não é o seu valor individual, mas sim o seu valor social, isto é, não se mede pelo tempo de trabalho que custa realmente ao produtor, no caso individual, mas pelo tempo de trabalho socialmente exigido para a produção" ${ }^{23}$. Como a maioria dos capitais individuais é coagida a aumentar a produtividade do trabalho de forma a se igualar ao primeiro que o fez, o novo padrão de produtividade tende a se generalizar. Quando isto ocorrer aqueles que não aumentaram a produtividade do trabalho estarão aplicando mais tempo de trabalho ao processo produtivo do que a quantidade que realmente têm condições de realizarem enquanto mais-valia.

No exemplo citado anteriormente o aumento da produtividade havia feito o valor individual da mercadoria em questão cair a $75 \%$ de seu valor original. Sendo que neste novo valor estão incluídos os meios de produção e matérias-primas e mais meia hora de trabalho. Após a generalização deste padrão este passa o valor social da mercadoria e não mais o seu valor individual. Assim sendo, aqueles que permanecerem produzindo de acordo com o padrão antigo continuarão gastando o mesmo tempo, isto é, uma hora para produzir a mercadoria. No entanto, desta uma hora aplicada ao processo produtivo apenas metade se transforma em valor. A outra metade simplesmente não conta como valor.

Então a concorrência impõe aos capitalistas individuais a necessidade de buscar a mais-valia relativa como condição para conseguirem produzir mais-valia. Isto reafirma as idéias postas no início deste item, segundo as quais a especificidade da mais-valia é ser uma forma de extração de excedente ligada a uma possível diferença temporal entre o tempo de trabalho socialmente necessário para a reprodução da força de trabalho e o tempo

\footnotetext{
${ }^{23}$ Marx, 1988, p. 240.
} 
de trabalho total. A sua condição de mera possibilidade fica mais explícita nos termos da mais-valia relativa, posto que tal diferença pode existir num momento e posteriormente deixar de existir caso o processo produtivo em questão não acompanhe as mudanças no padrão social de produtividade. Por isso, a especificidade da mais-valia é, justamente, que a sua produção não é determinada diretamente no processo produtivo, isto é, ela é mediada pelas condições da troca. Esta mediação é um elemento fundamental para que possamos identificar o modo de produção especificamente capitalista, no qual o capital tende a se pôr como sujeito não apenas em relação ao trabalho mas também em relação aos capitalistas, instituindo-se como forma de reprodução da riqueza (abstrata).

\section{2 - Reprodução ampliada: acumulação de riqueza abstrata.}

Já me referi anteriormente às relações entre a seção I e o restante de $O$ Capital, destacando que os pressupostos da primeira são posteriormente negados, mesmo que não negados de forma absoluta. São negados e, ao mesmo tempo, conservados como pressupostos da efetivação do capital. Eles continuam existindo, mas sua existência é reduzida à condição de momento do capital como processo de reprodução ampliada.

Talvez o elemento mais específico da seção I seja o destaque que ali se dá à troca, não só no sentido de ser a troca o ponto fundamental para a explicitação das características da mercadoria e do dinheiro, mas principalmente o destaque no sentido de se entender que a troca de mercadorias é o fundamento do processo de socialização então apresentado. Naquelas condições, um produtor faz sua mercadoria, que tem um valor-de-uso específico, com a pretensão de trocá-la por outra mercadoria, com um valor-de-uso diferente, o qual ele não produz. Quando se cumpre o percurso M-D-M a finalidade do processo de produção - que aí aparece como sendo a troca entre as mercadorias intermediada pelo dinheiro - parece ter sido cumprida.

A descrição da sociedade mercantil simples que está presente na seção I nos dá a impressão não apenas de que o capitalismo está baseado na troca de equivalentes - a qual já foi discutida na seção anterior - mas de que a troca em si é o fundamento deste modo de produção. Tudo se passa como se as pessoas produzissem para trocar. E não é isso que ocorre? Não é justamente isso que devemos entender como uma sociedade produtora de mercadorias? A resposta é sim e não. Sim, porque realmente a produção de mercadorias 
sem dúvida é uma produção voltada para a troca. Não porque não é a troca o seu fundamento último. Pondo de outra maneira, mesmo que no capitalismo as pessoas produzam para trocar - uma vez que produzem mercadorias -, a troca em si não é a finalidade do processo produtivo em geral. $\mathrm{Na}$ verdade ela é, isto sim, reduzida a um momento do processo produtivo especificamente capitalista, que é um processo de valorização. Vejamos isso em maiores detalhes.

$\mathrm{Na}$ troca a finalidade, como descrevi há pouco, é o valor-de-uso. Eu, como produtor, abro mão do valor de uso que produzo em troca de um outro valor de uso do qual eu tenho necessidade e não produzo. Mas como já afirmei na primeira parte deste capítulo, no capitalismo o valor de uso é negado pelo valor. Vimos como esta negação ocorre na relação entre o trabalho abstrato e o trabalho concreto e na dedução da forma dinheiro. Agora é o momento de retomarmos essa idéia.

Se na sociedade mercantil simples a fórmula que caracteriza a circulação é M-D-M, no capitalismo propriamente dito a fórmula é D-M-D'. Neste último caso a finalidade última do processo de circulação não é a troca e sim a valorização. Neste sentido faz-se necessário retomar outro ponto já indicado mas não desenvolvido, qual seja, o duplo sentido que o conceito de circulação tem na obra de Marx. Como já afirmado a circulação pode se referir à circulação strictu senso, que seria apenas a circulação de mercadorias isto é, compra e venda de mercadorias - assim como pode se referir à circulação lato senso, quando indica a circulação do capital. Esta última pode ser resumida na fórmula DM-D`o que demonstra, como também já foi afirmado, que ela inclui também o processo de produção. Isto fica mais evidente se observarmos a fórmula estendida do processo de circulação lato senso, que é a seguinte: D-M(FT/MP)...MV...M' - D'. Neste caso o dinheiro inicial está sendo trocado por mercadorias que são os fatores da produção, no caso, força de trabalho (FT) e meios de produção (MP); no processo de produção se gera mais-valia (MV), o que faz com que no final haja mais valor em forma de mercadorias (M') do que havia no início do processo. Após a venda das mercadorias, este valor a mais será transformado em dinheiro valorizado (D').

Neste percurso ocorreram várias trocas. A troca entre dinheiro e força de trabalho, a troca entre dinheiro e meios de produção e a troca entre mercadorias e dinheiro no final do processo. Cada uma destas trocas está ligada ao percurso M-D-M, o que demonstra que a troca de mercadorias como descrita na seção I continua existindo, mesmo que negada e, 
desta maneira, transformada num momento do processo de valorização. Esta é a característica da troca especificamente capitalista, que em seu conjunto se revela não apenas como âmbito da circulação de mercadorias, mas sim como a circulação do capital.

Da mesma forma que a troca em si não é a finalidade do processo produtivo, a valorização propiciada por apenas um ciclo do processo de circulação do capital, ou seja um ciclo D-M-D', também não o é. Como vimos na seção anterior é da natureza do capital a tendência a se pôr como sujeito do processo de produção da riqueza social. Isto significa que este processo tende a ser posto a serviço da continuidade da acumulação. É por isso que da análise do processo de produção é preciso passar à análise da reprodução.

O tema da reprodução é bastante rico - principalmente se incluirmos na discussão significados que vão para além do capitalismo e da teoria econômica marxista - e por isso merece uma atenção mais detida, o que ocorrerá no capítulo 4. Mesmo assim, por enquanto vejamos algumas contribuições que a análise da passagem da reprodução simples para a reprodução ampliada podem nos trazer.

Como reprodução simples entendo a reposição das condições da produção. Entre tais condições podem-se incluir os fatores da produção, como a força de trabalho e os meios de produção, mas também as relações sociais próprias da produção de mercadorias, por exemplo a separação entre produtores diretos e meios de produção e a conseqüente reafirmação do trabalho assalariado. Mas não se inclui nos termos da reprodução simples a continuidade da acumulação a qual só encontraremos como elemento fundante do processo de reprodução ampliada.

Se a reprodução ampliada está fundada na possibilidade da acumulação esta, por sua vez, está fundada numa cisão interna ao capital, qual seja, aquela entre o capital constante e o capital variável, ou entre o trabalho morto e trabalho vivo. A separação entre trabalho vivo e trabalho morto é diretamente dependente da separação entre os instrumentos de produção e o trabalhador. Graças a tal separação ambos - trabalhador e instrumentos de produção - tornam-se mercadorias, ou seja, tornam-se meios de produção e força de trabalho. A compra destas duas mercadorias e o consumo adequado de ambas permite ao capitalista promover a produção de mais-valia, que ocorre, como vimos, quando o valor produzido pela força de trabalho ultrapassa o valor pago por ela. 
Se já afirmei que a mais-valia absoluta não é suficiente para a efetivação do capital enquanto capital isto significa que ela não é suficiente para a reprodução ampliada, por meio da qual o capital se efetiva. Daí a necessidade já posta de considerarmos novamente a mais-valia relativa. Mas o destaque agora vai para as mudanças que a necessidade de produção de mais-valia relativa impõem ao processo produtivo e, para além dele, ao processo de reprodução em geral.

No último item já estava indicado o sentido geral da necessidade de se buscar a mais-valia relativa. Tal sentido é o da constante busca do barateamento das mercadorias por meio do aumento da produtividade do trabalho. Mas o aumento da produtividade, por sua vez, depende da maneira como está organizado o processo produtivo. Depende, na verdade, da maneira como a mercadoria força de trabalho é consumida durante este processo. Com a subsunção real do trabalho ao capital podemos afirmar que a mercadoria força de trabalho passa a ser consumida pelos meios de produção e não mais o inverso. Ou, numa formulação que se aproxima da idéia do capital como um vampiro posta por Marx, o trabalho vivo passa a ser consumido pelo trabalho morto, com o que este último consegue se revivificar ${ }^{24}$.

Temos neste caso uma cisão interna ao capital - entre capital constante e capital variável - que por um lado permite que haja o processo de valorização, posto que é justamente nesta relação que o trabalho é transformado na mercadoria força de trabalho que tem, por sua vez, a propriedade de poder ser consumida pelos meios de produção de forma a ter sua produtividade ampliada em favor da acumulação. Esta possibilidade é dada, justamente, pelo fetichismo do capital. Mas, por outro lado, esta mesma cisão e este mesmo fetichismo produzem a autonomização da estrutura técnica ${ }^{25}$ pondo como exigência ao processo de reprodução que se crie um setor voltado à produção de máquinas e que a relação entre este setor e o de produção de bens de consumo individual seja minimamente equilibrada.

Quando nos referimos à reprodução ampliada, entendemos a reposição das condições da produção propriamente capitalista. Se a produção só é propriamente capitalista quando os limites exteriores próprios da subsunção meramente formal do trabalho no capital são eliminados, esta eliminação só se dá por meio do constante aumento do uso de maquinaria no processo produtivo, isto é, um constante aumento do capital

\footnotetext{
${ }^{24}$ Cf. Marx, 1985, p. 51 e 52.

${ }^{25}$ Cf. Belluzzo, 1987. p. 96.
} 
constante. Mas para que isto seja possível há que se produzir um setor industrial voltado para a produção de meios de produção. Esta é a autonomização da estrutura técnica à qual me referi há pouco.

É interessante notar que esta autonomização pode ser vista também como uma conseqüência da cisão interna ao capital entre capital constante e capital variável. Conseqüência no sentido de que a necessidade de se criar este novo setor industrial voltado à produção de meios de produção vem, justamente, da necessidade de constante aumento da maquinaria no processo produtivo. Mas só isso ainda não demonstra a autonomização, posto que se dizemos que existe um setor de produção de meios de produção, apenas, porque eles são necessários no setor de produção de bens de consumo individual, não há propriamente autonomização mas simplesmente uma submissão do primeiro ao segundo. Começamos a nos aproximar mais da autonomização quando lembramos que o setor de meios de produção também é um setor capitalista e, desta forma, também tem de gerar acumulação.

Ou seja, com o surgimento do setor de produção de meios de produção passa a haver uma divisão no capital social global. Divisão esta que se dá entre dois setores que têm a característica de serem complementares entre si. O que o setor de meios de produção produz tem de ser consumido por ele mesmo e pelo setor de bens de consumo, o mesmo ocorrendo com o total de mercadorias produzido pelo setor de bens de consumo. Nestes termos, para que haja reprodução do capital social, agora cindido, há que se manter uma certa proporcionalidade de produção e consumo entre os dois setores. Com esta nova necessidade, característica da reprodução ampliada, a mudança tecnológica tem de ocorrer não apenas para que haja um constante aumento da produtividade do trabalho, mas também para que se mantenha a proporcionalidade intersetorial.

O que esta nova necessidade demonstra é, justamente, que a produção, no capitalismo, não pode ter a troca como objetivo. Se assim o fosse a produção só ocorreria sob as condições da necessidade material, seja das pessoas, seja do próprio processo produtivo. O que ocorre, no entanto, é que a produção e o consumo são envolvidos pela reprodução ampliada de forma que ambos tenham como objetivo a reposição das condições da acumulação. 


\section{3 - O lucro como riqueza abstrata.}

A produção da riqueza (abstrata) no capitalismo, como vimos, é baseada na produção de mais-valia. A mais-valia, no entanto, não se realiza imediatamente como riqueza nas mãos dos proprietários do capital. Não se realiza imediatamente, para começar, devido à distribuição da mais-valia produzida entre os juros referentes ao dinheiro emprestado, a renda da terra e o lucro do capital produtivo. Mas como estou considerando neste trabalho os juros e a renda da terra como formas não propriamente capitalistas de apropriação sobre a riqueza, só nos interessa, por enquanto, o lucro sobre o capital produtivo. Desta forma consideremos, pelo menos por enquanto, que toda a mais-valia se transforma em lucro.

Bem, mas se considerarmos que toda a mais-valia se transforma em lucro, pode parecer inútil fazer a diferenciação entre estes dois conceitos. Da mesma forma, com essa pressuposição, a idéia de que a mais-valia não se realiza imediatamente como riqueza nas mãos dos proprietários do capital pode parecer sem sentido. Mas isso só se desconsiderássemos uma outra problemática, para além daquela da distribuição, sobre as relações entre mais-valia e lucro. Esta problemática é a da transformação dos valores em preços de produção.

Muita polêmica se criou, tanto entre marxistas como entre seus críticos, em torno do problema da transformação dos valores em preços de produção. O fundamento da polêmica é, principalmente, o capítulo IX do livro 3 de $O$ Capital, no qual Marx insere a idéia de que as mercadorias não são trocadas pelos seus valores (como havia afirmado nos livros 1 e 2), mas sim pelos seus preços de produção, sendo estes os preços que se consegue "calculando a média das diferentes taxas de lucro das diferentes esferas da produção e adicionando essa média aos preços de custo [capital constante mais capital variável] das diferentes esferas da produção" ${ }^{26}$. Mas então vejamos de que se trata a polêmica.

Para começar é importante destacar que estando presente, justamente, no livro 3, esta discussão está diretamente ligada à consideração das relações mais concretas - no percurso de apresentação categorial de Marx - entre o âmbito da produção e o da circulação. Neste sentido se torna fundamental a consideração de que neste estágio do desenvolvimento categorial a concorrência passa a ter um papel fundamental. Ao contrário

\footnotetext{
${ }^{26}$ Marx, 1988, vol. V, p. 117.
} 
dos estágios anteriores nos quais o capital ainda era discutido como algo unitário ou como dividido entre dois setores que precisavam manter uma certa proporcionalidade entre si (e, portanto, tinham uma relação de complementaridade) agora o capital é visto como fragmentado em inúmeros capitais individuais que têm uma relação de mútua negação entre si. Esta fragmentação gera não apenas concorrentes em cada ramo da produção como já havia sido indicado durante explicação sobre a mais-valia relativa, quando cada capital individual tinha de buscar o barateamento de sua mercadoria - mas, inclusive, põe os capitais individuais para concorrerem pelo maior lucro possível entre os diversos ramos de produção existentes.

Nesta busca dois elementos são muito importantes. Em primeiro lugar a taxa de lucro que cada ramo pode oferecer de acordo com suas especificidades técnicas (composição orgânica) e de acordo com as condições da concorrência em cada momento e em cada lugar. Em segundo lugar, o tempo de rotação próprio a cada ramo. Deve-se lembrar que o tempo de rotação exprime o tempo necessário para o capital completar um ciclo D-M-D' completo, isto é, não apenas ser produzido como ser realizado enquanto capital. Quanto menor for seu tempo de rotação, preservando-se iguais as outras condições, mais atrativo tende a ser um ramo da produção.

Com estas novas considerações, vemos que a busca pela acumulação agora não é mais expressa como uma necessidade imanente do capital como uma totalidade abstrata (mesmo sendo uma abstração é uma abstração concreta), assim como a reprodução ampliada não é mais entendida como a necessidade do capital social total repor suas condições de reprodução. Estas buscas são agora expressas como características de capitais individuais que têm de seguir a lei coercitiva da concorrência como condição de sua própria reprodução. Na verdade, é justamente por meio da concorrência que o capital se efetiva enquanto forma de reprodução social.

Por enquanto é preciso destacar que a concorrência tem um papel fundamental na problemática da transformação dos valores em preços de produção e, com isso, nas relações entre mais-valia e lucro. Este papel é o de reduzir as taxas de lucro a uma taxa média de lucro. O que esta redução (à qual vou me referir, seguindo Fausto, como princípio da igualdade dos $\operatorname{lucros}^{27}$ ) demonstra é que diferentes capitais com igual

\footnotetext{
${ }^{27}$ Cf. Fausto, 1987, p. 116.
} 
magnitude devem produzir lucros médios também iguais. Isto independentemente destes capitais apresentarem proporções diferentes entre sua parte constante e sua parte variável.

Note-se que quando o excedente é expresso em mais-valia ele é visto como originário apenas da parte variável do capital. Mesmo no caso da mais-valia relativa em que o aumento da massa de mais-valia está diretamente ligado ao aumento do capital constante, não é este a fonte da mais-valia. Sua fonte continua sendo o capital variável, ou seja, a força de trabalho, a qual passa a ser mais produtiva com o aumento do capital constante. Já quando se adota a forma do lucro para expressar o excedente, a distinção entre o capital constante e o capital variável deixa de fazer sentido, posto que o lucro é, justamente a relação entre o capital total que foi empregado e o seu aumento. Não importa, na medida do lucro se este aumento veio da parte constante ou da parte variável do capital. Não que ele possa vir da parte constante, a diferença na verdade é que na medida do lucro nem é posta a questão da divisão do capital entre o capital constante e o variável.

Mas então se cria um problema, uma vez que a mais-valia e o lucro só seriam iguais e as mercadorias produzidas por estes capitais diferentes só estariam sendo trocadas pelo seu valor caso a composição orgânica de cada um destes capitais fosse idêntica. Vejamos um exemplo numérico ${ }^{28}$ para esclarecer a questão.

Considerando que a composição orgânica de um capital é a proporção entre o capital constante $(\mathrm{Kc})$ e o capital variável $(\mathrm{Kv})$, suponhamos que dois capitais tenham a mesma composição orgânica. Em cada um o capital constante é de 50 e o capital variável também. Vamos supor, ainda, que a taxa de mais-valia é de $100 \%$ em ambos, o que significa que se o capital variável (capital empregado na compra da força de trabalho) é de 50, a mais-valia produzida (M) também é de 50. Portanto, o capital empregado ( $\mathrm{Kc}+\mathrm{Kv}$ ) - ou preço de custo - é igual a 100, o valor total $(\mathrm{Kc}+\mathrm{Kv}+$ Mais-Valia) da mercadoria produzida é de 150 e a taxa de lucro $(\mathrm{M} /(\mathrm{Kv}+\mathrm{Kc}))$ é de $50 \%$, isso para ambos os capitais. Cumprem-se, neste caso, duas exigências diferentes, uma da lei do valor, segundo a qual as mercadorias são trocadas pelos seus valores; a outra, do princípio da igualdade dos lucros, segundo a qual capitais de mesma magnitude devem produzir lucros iguais. No entanto, se esta condição de igualdade da composição orgânica fosse a regra do capitalismo os conceitos de capital constante e capital variável perderiam grande parte de sua razão de ser.

\footnotetext{
${ }^{28}$ Parte desse exemplo numérico foi retirada de Harvey, 1990, páginas 72 e 73.
} 
Ao contrário da economia política clássica (e da neoclássica ou da corrente marginalista), Marx não dividiu o capital, apenas, em capital fixo e capital circulante. Ele também promoveu uma outra divisão que é aquela entre o capital constante (que não gera um novo valor) e o capital variável (que gera um novo valor). O primeiro é composto pelos meios de produção, matérias-primas e materiais auxiliares. O segundo é composto pela força de trabalho. A força de trabalho produzida pelo trabalhador tem a capacidade de transferir o valor acumulado nos elementos do capital constante para a nova mercadoria que está sendo produzida e, além disso, tem a capacidade de gerar um valor novo, uma riqueza que não existia, valor este dividido entre o salário e a mais-valia. Esta divisão é importante, como vimos, para compreendermos a produção da mais-valia e, como veremos, para se especular sobre a chamada lei tendencial da queda da taxa de lucro. Por enquanto, vejamos o que ocorre com os valores e os preços de produção quando as composições orgânicas de dois capitais não são idênticas.

Ao invés de 50 de Kc e 50 de Kv para cada um dos capitais considerados, vamos supor que o Capital I é composto por 80 de Kc e 20 de Kv, enquanto o Capital II por 20 de Kc e 80 de Kv. Mantendo inalterada a taxa de mais-valia, o primeiro apresentaria uma mais-valia total de 20 e o segundo uma mais-valia total de 80 . Com isso, o valor total da mercadoria produzida pelo Capital I seria de 120, enquanto o da mercadoria produzida com o Capital II seria de 180. Repare-se que o capital empregado, isto é, o valor de custo de ambas é o mesmo, ou seja, 100. Calculando-se as taxas de lucro podemos verificar que o Capital I apresentaria uma taxa de lucro de $20 \%$ e o Capital II de $80 \%$. Neste caso, mantém-se a lei do valor, posto que as mercadorias estão sendo trocadas pelos seus valores, isto é, pelo tempo de trabalho socialmente necessário para produzi-las. No entanto, o princípio da igualdade das taxas de lucro, segundo o qual capitais iguais devem apresentar lucros também iguais, está sendo absolutamente transgredido. E qual é o problema de se transgredir tal princípio?

Em condições de plena concorrência se pressupõe que haja uma taxa média de lucro devido à tendência dos capitais individuais em migrarem dos ramos menos lucrativos para os mais lucrativos. A priori, de acordo com o exemplo numérico que estou usando, os capitais empregados nos ramos com menor composição orgânica, isto é, com mais capital variável tenderiam a ser mais lucrativos. Isto, no entanto, atrairia mais capitais para estes ramos o que, devido à explosão da oferta, diminuiria os lucros nesta área e aumentaria nas outras que antes tinham lucro menor. Assim sendo, pelo conjunto da relação entre oferta e 
procura e pela ação da composição orgânica dos diversos capitais, tende a se formar, numa economia de mercado propriamente dita, uma taxa média de lucro segundo a qual capitais com igual magnitude devem gerar lucros também iguais ${ }^{29}$.

Desta forma, o que ocorre é que a taxa de lucro dos capitais I e II é igualada pelo mercado, para nosso exemplo, em $50 \%$. Com esta nova taxa de lucro podemos nos referir aos preços de produção. Como apontei acima, os preços de produção são aqueles que se consegue "calculando a média das diferentes taxas de lucro das diferentes esferas da produção e adicionando essa média aos preços de custo das diferentes esferas da produção". Neste caso, sendo que o preço de custo $(\mathrm{Kc}+\mathrm{Kv})$ dos dois capitais aqui considerados é igual a 100, bastaria somar a isso os 50 determinados pela taxa de lucro e chegaríamos à conclusão de que ao invés do Capital I ser trocado pelo seu valor (120) ele foi trocado pelo seu preço de produção (150), o que também ocorreu com o Capital II (valor 180, preço de produção 150). Ocorreram, portanto, “desvios” entre o valor das mercadorias e seu preço de produção, pelo qual elas foram trocadas.

Para muitos, estes desvios desqualificam a teoria do valor e a põem como uma contradição - ou uma incoerência - da teoria econômica marxista. Porém, numa leitura mais rigorosa, percebe-se justamente a identificação do fundamento do capital, o impulso pela maximização dos lucros por meio do aumento da produtividade do trabalho, impulso este que pode ser identificado como a abstração da riqueza no sentido da separação entre a sua produção e a sua realização.

No exemplo numérico acima considerado, o Capital I que deveria resultar numa mercadoria com valor 120, sofreu um desvio para 150. Por sua vez, o Capital II que deveria resultar numa mercadoria de 180 sofreu um desvio para 150. Neste caso poderíamos afirmar que o primeiro produziu 20 de valor excedente, mas realizou 50, enquanto o segundo produziu 80 mas só realizou 50. Com isso, percebemos que há uma

\footnotetext{
${ }^{29}$ A relação entre oferta e procura não é vista por Marx de forma abstrata segundo os pressupostos da economia política clássica, a qual - num jogo conceitual muito próximo do hegelianismo - põe a lei da oferta e da procura como uma síntese abstrata entre os interesses particulares e universais. Para Marx, oferta e procura não têm um caráter autônomo (mesmo tendo um importante papel na efetivação das determinações do capital), sendo determinadas pela própria estrutura da produção capitalista. Essa posição fica clara, por exemplo, no seguinte trecho: "se a procura e a oferta determinam o preço de mercado, por outro lado, o preço de mercado e - levando-se a análise mais longe - o valor de mercado determinam a oferta e a demanda. Quanto à procura, isso é evidente, uma vez que esta se move em sentido oposto ao preço, aumenta quando esse cai e vice-versa. Mas isso vale também para a oferta. Pois os preços dos meios de produção que entram na mercadoria oferecida determinam a procura por esses meios de produção e também, portanto, a oferta das mercadorias cuja oferta inclui a procura por aqueles meios de produção. Os preços de produção são determinantes para a oferta de tecidos de algodão.” (Marx, 1988, Vol. IV, p. 140).
} 
separação entre a produção da mais-valia e sua realização em forma de lucro. Como põe Harvey, "a mais-valia se origina no processo de produção em virtude da relação de classe entre o capital e o trabalho, mas é distribuída entre os capitalistas de acordo com as regras da concorrência" 30 .

O que esta situação demonstra, novamente, é que, sob condições propriamente capitalistas, o conjunto da produção e realização de riqueza não é determinado de forma absoluta no âmbito da produção strictu senso. Para continuar na busca de um nível de concretude cada vez maior do processo de abstração, no qual o mercado é uma mediação entre a produção e a realização da riqueza, poderíamos considerar que a produção de um trabalho excedente não significa, imediatamente, produção e realização de mais-valia.

A mais-valia, como já vimos, é a riqueza produzida mas não apropriada pelo trabalhador. A força de trabalho produz riqueza, esta riqueza se divide entre o salário e um valor a mais, que não é pago ao trabalhador e que se transforma em mais-valia. A priori, parece que se pode afirmar tranqüilamente que a mais-valia é igual ao sobre-trabalho, que a mais-valia é o excedente. No entanto, para destacar novamente, ela não é simplesmente o excedente, mas sim a forma do excedente na sociedade capitalista. Ser a forma do excedente propriamente capitalista significa, justamente, ser mediada pela realização de acordo com as condições do mercado.

Estas condições do mercado é que fizeram o Capital I produzir 20 de mais-valia mas realizar 50, enquanto o Capital II produziu 80 e só realizou 50. Mas não estou me referindo às condições de mercado como situações aleatórias, como se o predominasse no mercado um jogo em que a sorte fosse o fator determinante. É preciso lembrar que o papel do mercado na produção dos desvios entre os valores e os preços de produção foi igualar a taxa de lucro de forma que o capital com menor composição orgânica realizasse menos mais-valia que o capital com maior composição orgânica. As condições de mercado neste caso não foram aleatórias, nem estiveram ligadas ao fator sorte. Ao contrário elas agiram num sentido bastante específico, qual seja, o de beneficiar o capital com composição orgânica maior.

Quando expus a passagem da mais-valia absoluta à relativa insisti em seu caráter necessário devido ao processo de concorrência que obrigava cada capital individual a

\footnotetext{
${ }^{30}$ Harvey, 1990, p. 71.
} 
buscar o aumento da proporção de trabalho morto em relação ao trabalho vivo. Agora, na condição de uma maior generalização da concorrência é reposta e intensificada esta mesma necessidade, uma vez que se a mais-valia é gerada no processo produtivo, o que determina sua realização é a concorrência, na qual cada capital individual tem de procurar aumentar sua composição orgânica constantemente.

Podemos dizer, com isso, que o desvio entre os valores e os preços de produção é uma conseqüência do desencontro entre a produção de mais-valia e sua realização como lucro. Este desencontro é o próprio fundamento do processo de produção e realização da riqueza propriamente capitalista, segundo o qual a riqueza só se efetiva com a condição da busca da maximização dos lucros por meio da intensificação da produtividade do trabalho (representada aqui pelo aumento da composição orgânica). Chamei este tipo de riqueza de riqueza abstrata justamente por ela não ser determinada no processo produtivo direto, tendo sempre de ser mediada pelas condições da troca propriamente capitalista. Só para fechar este item, vejamos como esta idéia aparece no seguinte trecho de Marx;

... a mais-valia, na forma de lucro, não se refere mais à parte do capital investida em trabalho, do qual ela se origina, mas ao capital total. A taxa de lucro torna-se regulada por leis próprias que permitem e até condicionam uma alteração da mesma sob uma taxa de mais-valia constante. Tudo isso oculta mais e mais a verdadeira natureza da maisvalia e, daí, o mecanismo efetivo do capital. Mais ainda, isso ocorre através da transformação do lucro em lucro médio e dos valores em preços de produção, nas médias reguladoras dos preços de mercado. Surge aqui um complicado processo social intermediário, o processo de compensação de capitais, que separa os preços médios relativos das mercadorias de seus valores e os lucros médios das diversas esferas da produção (abstraindo totalmente dos investimentos individuais de capital em cada esfera produtiva) da exploração efetiva do trabalho pelos capitalistas específicos. Não só parece assim, mas aqui de fato o preço médio das mercadorias é diferente de seu valor, isto é, do trabalho nelas realizado, e o lucro médio de um capital específico, diferente da mais-valia que este capital extraiu dos trabalhadores empregados por ele. $O$ valor das mercadorias aparece imediatamente só ainda na influência da força produtiva do trabalho sobre baixas e altas dos preços de produção, sobre seu movimento, sobre seus movimentos e não sobre seus limites últimos. O lucro aparece só ainda determinado 
acessoriamente pela exploração imediata do trabalho, na medida em que esta permite ao capitalista realizar um lucro discrepante do lucro médio sob preços de mercado reguladores dados, aparentemente independentes dessa exploração ${ }^{31}$.

\section{4 - Separação, efetivação da crise e o capital como movimento.}

No capítulo 2 procurei identificar na crise o impulso que faz do capital um movimento de auto-expansão. No presente capítulo, até o momento, procurei identificar a cisão interna ao capital, entendendo que tal cisão promove a abstração da riqueza, o que foi definido como uma intermediação da produção de riqueza pelas condições da troca propriamente capitalista, a troca que tem a valorização como necessidade. Agora é preciso relacionar de forma mais explícita estes dois momentos para demonstrar que a necessidade de auto-expansão do capital é determinada pelo seu fundamento contraditório. Para isso, vou me referir a alguns conteúdos, ou formas de manifestação, da crise, procurando demonstrar que a crise é, justamente, a manifestação da cisão interna do capital.

Comecemos com a identificação da crise na troca. Como vimos, no ato da troca há uma relação entre duas mercadorias segundo a qual uma delas assume a forma valor relativa e a outra assume a forma valor equivalente. Desta maneira a primeira tem seu valor medido no valor-de-uso da segunda. Passando da forma simples do valor para a forma desdobrada do valor temos uma mercadoria assumindo o papel da forma valor relativa enquanto as inúmeras mercadorias do mundo das mercadorias assumem a forma equivalente. Já, quando chegamos à forma geral do valor encontramos uma mercadoria assumindo a forma do equivalente universal, isto é, dinheiro, passando a ser a mediação para a troca entre todas as outras mercadorias.

Neste percurso conceitual, o que encontramos é a cisão interna à mercadoria - a cisão entre valor de uso e valor - se exteriorizando na separação entre mercadoria e dinheiro. O dinheiro é, portanto, produto de um desenvolvimento da forma mercadoria e da generalização do processo de produção de mercadorias. Mas quando o dinheiro passa a existir como dinheiro, isto é, como equivalente universal e se põe, portanto, como mediador de todas as trocas, cria-se também a separação entre o ato da venda e o ato da compra.

\footnotetext{
${ }^{31}$ Marx, O Capital, Apud Grespan, 1998, 203.
} 
Ao contrário do escambo, no qual há uma troca imediata entre duas mercadorias e, desta forma, compra e venda são atos idênticos, no processo de intercâmbio que envolve o dinheiro, a venda de uma mercadoria em um momento pode não resultar, automaticamente, na compra de outra. Compra e venda passam a ser momentos independentes, podendo estar separados no tempo e no espaço. Esta independência, no entanto, é apenas superficial (aparente), pois fundamentalmente, as compras e vendas estão necessariamente ligadas. A prova disto é, justamente, que o entesouramento generalizado - possível apenas pela autonomização do dinheiro em relação às mercadorias - promove uma crise também generalizada.

A crise, neste caso é, portanto, a manifestação da ligação fundamental entre estes dois momentos - compra e venda - que superficialmente aparecem como separados. Isto significa que dinheiro e mercadoria são determinados por uma separação na união, de forma que mesmo em sua independência, cada um tende a atrair o outro se repelindo de si mesmo, isto é, a mercadoria - para se realizar enquanto portadora de valor - tem de ser trocada por dinheiro e este só cumpre a sua função ao efetivamente servir como meio ${ }^{32}$ para comprar uma mercadoria ${ }^{33}$.

Esta manifestação da crise é um produto direto da forma mercadoria, mas ainda é apenas uma possibilidade exterior à lógica do capital, ou seja por enquanto não pode ser vista como um momento constituinte do capital $^{34}$, até porque ainda não chegamos à definição do conceito de capital com todas as suas determinações. A consideração da troca, como vimos, não é, ainda, a consideração do capital. Como já vimos, na troca o objetivo é

\footnotetext{
${ }^{32}$ Isto se considerando, ainda, o dinheiro como meio de pagamento neste contexto da troca entre dinheiro e mercadorias.

${ }^{33}$ Como coloca Ruy Fausto, "na relação entre o dinheiro e a mercadoria há mais do que isto [mais do que a simples diferença entre duas mercadorias]: há entre os dois uma espécie de tensão. Eles se atraem mutuamente, cada um deles repele a si próprio, mas por isso mesmo eles podem entrar em conflito (nas crises)". (Fausto, 1987, p. 98).

${ }^{34}$ Grespan estrutura a apresentação do conceito de crise em seu Negativo do Capital da seguinte maneira. Em se tratando da troca a crise é uma mera possibilidade, até porque a não-crise, que seria a valorização, ainda não está posta como necessidade. Ao se considerar a produção capitalista ela passa a ter o estatuto de potência, posto que a necessidade de se buscar a mais-valia relativa torna-se uma causa determinada da criação de crises. Mas como o capital - neste momento da apresentação categorial - é ainda capital em geral ele carrega dentro de si, igualmente, a potência da crise e a potência de sua realização, por isso é, ainda potência e não efetividade. Num terceiro momento, o capital em geral aparece cindido entre os setores próprios dos esquemas de reprodução e daí surge a necessidade - criada por esta mesma cisão - de se manter a proporção entre ambos. A crise é, então, a crise da desproporção intersetorial. No quarto e último momento, o capital não é mais apenas capital em geral, posto que está fragmentado nos capitais individuais e, desta forma, envolve a concorrência. Neste momento a crise assume a forma da queda tendencial da taxa de lucro e da sobreacumulação As quais são analisadas em sua efetividade e não em sua necessidade absoluta. Nos parágrafos seguintes minhas referências ao conceito de crise se inspiram nesta apresentação da crise feita por Grespan, mesmo incorporando outras contribuições.
} 
a substituição de um valor-de-uso por outro (mesmo que de forma intermediada pelo dinheiro), enquanto no capital o objetivo é a valorização.

A valorização se dá por meio da mais-valia a qual só pode ocorrer na produção de mercadorias. Mas a simples produção de mais-valia absoluta também é insuficiente para definir o capital, posto que neste caso o que temos é uma situação na qual o trabalho produz mais valor do que consome pela simples possibilidade de produzir este valor num tempo menor que o tempo total da jornada de trabalho. A jornada de trabalho aparece como um limite externo à lógica do capital. Neste caso, se houvesse uma situação na qual os capitalistas não conseguissem impor um aumento da jornada de trabalho, o processo de valorização ficaria estagnado, o que representaria uma crise. Mas esta crise tem causas externas à lógica do capital.

A produção propriamente capitalista é aquela que tende a eliminar os limites externos à valorização, o que só pode se dar com a produção de mais-valia relativa. Com isso chegamos à idéia de subsunção real do trabalho no capital, o que significa que o processo de trabalho passará a ser organizado como processo de valorização e de acordo com as necessidades de auto-expansão do capital. Mas quando se trata da crise, a subsunção real não significa apenas que o capital se põe como parâmetro organizador da produção. Agora devemos entendê-lo também como gerador de causas da crise. Causas que ao serem geradas no interior do capital produzem um novo estatuto para a crise. A crise se torna determinada de acordo com a própria lógica do capital.

Se por um lado o impulso pela constante autovalorização leva o capital a eliminar os limites externos à sua expansão, o leva igualmente a produzir internamente seus próprios limites. Por isso, ao passarmos da consideração da troca de mercadorias para a consideração do capital em geral ${ }^{35}$ é preciso incluir entre nossas preocupações o que Harvey chama de dinâmica da acumulação. No Capítulo 6 de seu The Limits to Capital, este autor analisa três modelos da dinâmica da acumulação como aparecem na obra de Marx. O primeiro envolve o que poderíamos chamar de uma relação entre a grandeza de capital a ser investido e a de força de trabalho a ser explorada, relação esta permeada pela tendência ao aumento do trabalho morto em relação ao trabalho vivo. O segundo modelo se dedica às polêmicas acerca dos esquemas de reprodução ampliada do próprio Marx. $\mathrm{O}$

\footnotetext{
${ }^{35}$ Considerar o capital em geral significa ainda não considerá-lo como dividido em setores (como se dá na consideração dos esquemas de reprodução) e, muito menos em sua forma efetiva, qual seja, a forma fragmentada em capitais individuais, o que envolve, necessariamente, a concorrência.
} 
terceiro procura fazer uma síntese envolvendo os dois primeiros e a problemática da queda da taxa de lucro, chegando assim à importante noção de sobreacumulação. Estes três modelos podem ser encontrados, respectivamente, no primeiro, no segundo e no terceiro livro de o Capital. Assim, podemos afirmar (mesmo que Harvey não o diga explicitamente) que eles correspondem a diferentes fases a apresentação categorial.

De qualquer forma, o que nos interessa, ao menos por enquanto ${ }^{36}$, é que nos três modelos há, por trás das dificuldades para se efetivar a acumulação, o impulso do próprio capital para se expandir como forma de escapar das causas da crise criadas por ele mesmo. Ou seja, a meu ver, como "modelo da dinâmica da acumulação" Harvey está entendendo a maneira como o capital lida com os limites que ele mesmo põe à acumulação. Desta forma a acumulação é posta como um movimento necessariamente dinâmico, pois se não houver esta dinâmica os limites que o próprio capital põe para si próprio fazem com que ele mesmo deixe de ser capital. É neste sentido que podemos entender a crise não apenas como a não acumulação, mas também como parte constituinte do impulso à expansão. A seguir vejamos como isso aparece em cada um dos três modelos.

No primeiro modelo, a dinâmica da acumulação precisa lidar com uma tensão criada por dois movimentos paralelos próprios do âmbito da produção. Por um lado, o capital precisa realizar a subsunção real como forma de eliminar o limite externo à acumulação representado pelo limite da jornada de trabalho. Por outro, como capital ele precisa manter-se em expansão. Mas note-se a dificuldade existente na relação entre estas duas necessidades. A subsunção real só ocorre com a produção de mais-valia relativa, o que depende do constante aumento do trabalho morto em relação ao trabalho vivo. Mas como é bem representado na metáfora do vampiro, o trabalho morto só pode se revivificar, isto é, se valorizar, sugando trabalho vivo. Isto significa que há uma tendência a existir cada vez mais trabalho morto em busca de cada vez mais trabalho vivo. Isto é, se por um lado o capital, para se pôr como capital precisa aumentar sua parte de trabalho morto, por outro este mesmo trabalho morto aumentando tem de procurar cada vez mais trabalho vivo para ser sugado.

\footnotetext{
${ }^{36}$ Como já chamei a atenção no Primeiro Excurso sobre encontros e desencontros metodológicos, a perspectiva de Harvey é diferente da de Grespan no sentido de buscar não apenas analisar os textos de Marx mas também procurar entender os problemas colocados pela relação entre as contradições do capital e os outros âmbitos da socialização. Nestes modelos, por exemplo, Harvey dá grande ênfase à dificuldades que a dinâmica da acumulação encontra - fora do âmbito do capital - para se efetivar. Por enquanto, no entanto, não estou considerando, ainda, esta tentativa de Harvey de ir além de Marx.
} 
O que encontramos aí é uma situação crítica, como descrito no capítulo 2. Ou seja, o capital é cindido entre o trabalho morto e o trabalho vivo. Há uma tendência interna ao aumento do trabalho morto. Mas se internamente o capital se tornasse trabalho morto como um todo isso significaria sua extinção enquanto capital, da mesma forma que o vampiro morreria após eliminar o sangue dos vivos do qual se alimenta. Portanto, esta tendência interna ao capital de aumento do trabalho morto faz com que o capital tenha que fugir de si mesmo para ser o que é. Ou seja, faz com que o capital tenha de se expandir constantemente para continuar sendo capital ${ }^{37}$.

Neste caso, manter-se em expansão significa conseguir lidar com a relação entre o capital a ser investido e a disponibilidade de força de trabalho a ser comprada. Por um lado, o capital tende a eliminar a mão-de-obra do processo produtivo, gerando o exército industrial de reserva. Por outro, com a constante necessidade de reinvestimento do capital disponível é preciso reincorporar a mão-de-obra, levando à tendência de aumento dos salários e, desta forma, exigindo um aumento da proletarização. Mas é interessante reparar que estas duas tendências podem, simplesmente, se anular. Por isso, a crise neste momento da apresentação ainda tem apenas o estatuto de potência e não de necessidade.

No segundo modelo da dinâmica da acumulação, centrado na circulação e não mais na produção, o capital não é mais apresentado simplesmente como capital em geral. Agora ele é dividido entre dois setores (e segundo próprio Marx poderia ser dividido em um número maior) que juntos compõem o capital social global. Esta divisão está baseada no valor-de-uso produzido por cada um dos dois setores. O setor I produz meios de produção e o setor dois produz bens de consumo. A separação em setores é uma separação entre partes que devem ser complementares. Num estado de reprodução simples é possível se atingir um certo equilíbrio. Mas como esta complementaridade deve manter-se na reprodução ampliada, o capital deve se expandir constantemente.

O total de mercadorias produzido pelo setor I deve ser consumido por ele mesmo e pelo setor II, o qual apresenta a mesma necessidade. Por isso que se imaginássemos uma situação de reprodução simples seria possível encontrarmos uma medida de equilíbrio entre ambos. Mas ao lembrarmos que os dois setores precisam se expandir, posto que é

\footnotetext{
${ }^{37}$ Não deixa de ser ilustrativo relembrar a citação que fiz de Hegel no capítulo 2: "Surge ao mesmo tempo um modo peculiar de minha determinidade, a saber, que me sinto defeituoso, negativo, e encontro em mim a contradição que ameaça desfazer-me. Mas existo; eis o que sei e oponho-me à negação, à deficiência. Conservo-me e procuro anular a deficiência e, por isso, sou impulso. O objeto a que se dirige o impulso é, então, o objeto da minha satisfação, do restabelecimento da minha unidade".
} 
esta a necessidade própria do capital, vemos que se cria uma exigência de expansão de um setor em relação ao outro tanto como produtor como consumidor. A não expansão de um pode significar a não expansão do outro no sentido de que não se criaria a demanda efetiva para que este segundo pudesse também crescer. Novamente podemos visualizar uma cisão interna ao capital a partir da qual este produz seus próprios limites. Limites, no entanto, que devem ser superados pela expansão para que o capital possa de realizar como o que é.

Com base nesta idéia Rosa Luxemburgo produziu sua teoria do Imperialismo, segundo a qual o capitalismo teria de se expandir constantemente sobre sociedades não capitalistas como forma de garantir a possibilidade de um constante aumento de ambos os setores. Novamente encontramos a idéia de que o capital precisa fugir de si mesmo para se efetivar como o que é. Só é preciso fazer uma ressalva. Na teoria de Rosa Luxemburgo a óbvia finitude de sociedades não capitalistas levava à idéia do necessário colapso do capitalismo. Como demonstra Rosdolsky ${ }^{38}$, esta posição se baseia numa interpretação equivocada dos esquemas de reprodução de Marx. Na realidade não diretamente dos esquemas mas sim de sua posição na estrutura de $O$ Capital. Neste caso o erro de Luxemburgo foi fazer uma análise unilateral de Marx, esquecendo-se que naquele momento da apresentação (livro 2) o capital ainda é considerado como capital social global e não como o capital em sua efetividade (o que só ocorre no livro 3), o que significa que nem todas as determinações do capital estão postas naquele momento. Mesmo assim, como chama a atenção Harvey, a obra de Rosa Luxemburgo "se lida como tratado teórico sobre o que deverá acontecer se forem bloqueados todos os outros meios para a criação de espaço novo para a acumulação, é uma exposição brilhante" ${ }^{, 39}$. Isto, justamente, porque ela capta o impulso à expansão inerente ao capital.

Para finalizar este item, tratemos do terceiro modelo da dinâmica da acumulação. Este se refere a um momento da apresentação categorial no qual o capital já é conceituado de acordo com todas as suas determinações. Assim o é, em primeiro lugar, porque neste são consideradas as relações entre a esfera da produção e a da circulação e, em segundo lugar, porque agora o capital não é mais visto de forma abstrata, isto é, na forma do capital social global. Ao contrário, agora o capital é entendido justamente na sua forma mais concreta, qual seja, a da fragmentação do capital global em capitais particulares, o que inclui, necessariamente, a concorrência.

\footnotetext{
${ }^{38}$ Rosdolsky, 2001, p. 408 a 410.

${ }^{39}$ Harvey, 2005, p. 67.
} 
Mas antes de tratarmos do papel da concorrência, é importante destacar que o ponto central sobre a discussão da crise neste momento é passagem da mais-valia ao lucro. Esta passagem é de fundamental importância para entendermos as duas manifestações da crise que serão expostas a seguir, a queda da taxa de lucro e a sobreacumulação.

Vejamos primeiro a diferença entre mais-valia e lucro (novamente estou considerando que toda a mais-valia se transforma em lucro). Antes de retornarmos à idéia já trabalhada sobre a transformação dos valores em preços de produção e, conseqüentemente, da mais-valia em lucro, vejamos a importante distinção entre taxa de mais-valia e taxa de lucro. Enquanto a taxa de mais-valia é calculada pela relação entre o valor da força de trabalho e o valor a mais por ela produzido, a taxa de lucro é a relação entre este valor a mais e todo o capital investido.

Se lembrarmos que o capital total investido é composto por capital variável (que é a força de trabalho) e capital constante (meios de produção e matérias-primas que geram mais-valia) e relacionarmos isso à diferença entre a taxa de mais-valia e a taxa de lucro, percebemos que a tendência ao aumento do capital constante em relação ao capital variável provoca uma tendência à queda da taxa de lucro. Este e o núcleo do argumento de Marx para explicar a chamada lei tendencial de queda d taxa de lucro. É claro, no entanto, que o raciocínio é mais complexo do que isso e, até por sua complexidade, bem mais polêmico.

Provavelmente o centro da polêmica é a idéia de "lei tendencial". Como uma lei pode ser tendencial e continuar sendo lei? Bem, a noção de tendência começa a aparecer quando Marx enumera os fatores contra-atuantes à queda da taxa de lucro, isto é, fatores que fazem parte da lógica da acumulação capitalista e que vão contra esta queda. São eles, principalmente, o aumento da taxa de exploração (aumento da taxa de mais-valia), a diminuição dos custos do capital constante e a criação de um exército industrial de reserva que colaboraria com a geração de dois fatores: a queda dos salários abaixo do valor da força de trabalho e a menor necessidade, em alguns setores, de economizar mão-de-obra por meio do investimento em capital constante.

Alguns autores (segundo indicação de Grespan e Harvey) procuraram definir qual tendência deveria prevalecer, a da queda ou contra ela. Ao se provar que no final das contas continuaria predominando a tendência à queda, poderia se entender que os fatores contra-atuantes apenas retardariam a inevitável queda da taxa de lucro. No entanto, este tipo de discussão me parece infrutífera para a compreensão da reprodução capitalista, 
mesmo porque recai numa perspectiva que, a meu ver, é irrelevante tanto do ponto de vista teórico como do ponto de vista político, que é a de tentar prever o colapso do capitalismo.

Isso, no entanto, não significa que tenhamos que desistir da lei tendencial, mas, ao contrário, que precisamos procurar compreendê-la melhor. Tanto ela em si como sua posição na estrutura teórica de $O$ Capital. Sobre o significado da própria lei tendencial o que é preciso entender sobre a relação entre a tendência à queda e os fatores contraatuantes não é exatamente qual deles prevalece e sim que ambos são produtos de um mesmo fundamento contraditório do capital. Se não vejamos, a queda da taxa de lucro é provocada por um aumento da composição orgânica do capital (ou seja, mais capital constante em relação ao capital variável) causada pela constante busca do aumento da produtividade do trabalho. Mas, ao mesmo tempo, os fatores contra-atuantes citados anteriormente dependem, igualmente, deste mesmo aumento da produtividade do trabalho. É sobre isso que chama nossa atenção Belluzzo, no seguinte trecho;

A tendência ao declínio da taxa de lucro, à medida que avança o processo de acumulação, não exclui mas, ao contrário, supõe, não só o aumento (obvio) da massa de lucros, como também da taxa de maisvalia... Mas, de outra parte, ambos os processos implicam numa aceleração do processo de acumulação e, em conseqüência, numa elevação continuada da composição orgânica do capital, o que tende, dinamicamente, a contrariar aqueles dois efeitos. A acumulação capitalista evolui, assim, impulsionada pela tensão de dois movimentos paralelos que atuam em sentido oposto sobre a taxa de lucro. Assim, a tendência ao declínio da taxa de lucro não é senão a forma apropriada do modo de produção capitalista exprimir o progresso da força produtiva social do trabalho e, por isso mesmo, é a manifestação, por excelência, da natureza contraditória do processo de acumulação de capital $^{40}$.

A partir desta perspectiva podemos entender que a lei tendencial da queda taxa de lucro não deve necessariamente ser entendida como um declínio dos lucros que levaria à crise absoluta do modo de produção capitalista. Ao contrário, mesmo envolvendo dois movimentos contrários (o que dá seu caráter de tendência) ela deve ser entendida como fruto de um mesmo fundamento, que é o impulso constante ao aumento da produtividade

\footnotetext{
${ }^{40}$ Belluzzo, 1987, p. 102
} 
do trabalho por meio do aumento da composição orgânica. Deste modo o caráter de lei enunciado por Marx deve ser entendido da seguinte forma,

...esta é a forma das "leis" enunciadas por Marx em seu estudo do capitalismo, forma na qual a necessidade lógica característica da lei advém da própria contradição em que são postos seus termos. Em vez de um nexo não contraditório entre fenômenos ou entre estes e sua causa, a relação é "lei" exatamente quando seus termos se apresentam como os aspectos contraditórios de um fundamento comum, definidos como o contrário um do outro ${ }^{41}$.

Este entendimento sobre a lei tendencial à queda da taxa de lucro nos leva ao seu questionamento na estrutura da obra de Marx. Afinal de contas a impressão que se tem dela é que sua importância e sua especificidade em relação aos outros conceitos discutidos em $O$ Capital deveriam ter menos destaque do que, em geral, têm. Sobre isso, Harvey supõe que Marx acabou dando mais destaque do que deveria à lei porque procurava demonstrar o caráter crítico de sua teoria em relação à economia política clássica, a qual já havia tratado o tema. O resultado foi que para fazer isso "Marx se distanciou da lógica de seu argumento a tal ponto que o que deveria ter sido uma premissa tangencial [a queda da taxa de lucro] aparece como fundamental, enquanto a premissa fundamental acaba ficando enterrada em uma massa de argumentos tangenciais". Neste caso, premissa fundamental, segundo Harvey, seria "a contradição entre a evolução das forças de produção por um lado e, por outro, as relações sociais sobre as quais se baseia a produção capitalista"42.

Esta contradição se expressa no problema da sobreacumulação, que é o fundamento de todos as crises apontadas até aqui. A sobreacumulação não deve ser entendida necessariamente como uma superprodução, o que diminui muito seu campo de abrangência. Ao contrário, ela deve ser entendida como a impossibilidade (momentânea, localizada, setorial etc) de se levar adiante a acumulação devido a problemas criados pela própria natureza contraditória do capital. E afinal como poderíamos delimitar esta natureza contraditória do capital a não ser por sua cisão interna, que num caminhar do abstrato ao concreto passa pela cisão da mercadoria entre valor e valor-de-uso, com sua externalização para as relações entre mercadoria e dinheiro; pela cisão entre capital constante e capital variável; pela cisão do capital social global entre setores e, finalmente, chega à

\footnotetext{
${ }^{41}$ Grespan, 1998, p. 215.

${ }^{42}$ Harvey, 1990. p. 185. Tantos esta citação como a anterior pertencem ao mesmo parágrafo.
} 
fragmentação do capital social global em capitais particulares. Afinal como nos chama a atenção Belluzzo ao explicar a tendência ao aumento da composição orgânica do capital,

O progresso técnico passa a fazer parte das virtudes do sujeito-capital e como tal só pode se exprimir como arma de combate dos capitais individuais. Neste sentido, é indiferente para o capitalista introduzir uma inovação que diretamente lhe rebaixe os custos salariais ou reduza input de matérias-primas ou mesmo substitua uma máquina menos eficiente por uma mais eficiente. O importante é que a introdução da inovação confira ao capital individual capacidade de reduzir o valor de seu produto abaixo de seu valor social.

É inequívoco que a generalização das inovações tende a reduzir o tempo de trabalho abstrato e que só o faz substituindo de forma crescente trabalho vivo por trabalho objetivado nos meios de produção. Mas, ainda que isto seja consequiência inevitável do processo e ao mesmo tempo sua razão mais profunda, sua razão imediata está dada pelo confronto entre as parcelas em que se fraciona o capital social ${ }^{43}$.

Com isso voltamos, novamente, à idéia de que o capital fracionado internamente precisa fugir de si para continuar sendo o que é. Agora - lembrando que atingimos o ponto alto da concreção do capital - esta fuga de si mesmo pode ser vista na forma como ela efetivamente se dá. Os capitais individuais precisam concorrer entre si para se reproduzirem. Justamente nesta concorrência se produz o impulso interno à expansão capitalista. É neste movimento que se pode dizer que o capital tende a eliminar os limites externos à sua expansão ao criar internamente seus próprios limites à reprodução. E é justamente neste sentido que a crise pode ser vista não apenas como a não acumulação mas também como constitutiva do impulso à acumulação Por isso que,

...apreendida como expressão da negatividade imanente ao capital, a crise está na base da crítica ao capitalismo, conforme um significado especificamente marxiano de 'crítica': não se trata de uma reflexão exterior que aponta os limites deste sistema, e sim dos limites alcançados por ele mesmo com o desenvolvimento de suas potencialidades e com a

\footnotetext{
${ }^{43}$ Belluzzo, 1987, p. 108.
} 
exposição de suas contradições fundamentais nos processos que

realiza ${ }^{44}$.

\title{
3.5 - A separação como alienação
}

Provavelmente um dos elementos que mais marca a diferença entre a teoria econômica marxista e as não marxistas (particularmente a economia política clássica e suas derivações contemporâneas) é a perspectiva sobre a relação entre o capitalismo e os outros modos de produção. Isso porque na economia política clássica, por exemplo, o capitalismo é visto como uma mera continuidade, e na verdade um aperfeiçoamento, das formas anteriores de economia de mercado. É certo que esta perspectiva acerca do capitalismo não está totalmente ausente entre autores marxistas. Mesmo em alguns textos de Marx ${ }^{45}$ podese encontrar idéias que justifiquem a adoção deste ponto de vista, digamos, continuísta. No entanto, a meu ver, o caráter distintivo da teoria econômica marxista é entender o capitalismo como uma forma específica de reprodução social. Em termos históricos apresentei esta perspectiva por meio de uma interpretação das idéias de Ellen Wood - às quais voltaremos a seguir - mas em termos teórico-conceituais a observação da especificidade do capitalismo por Marx é marcada pelo seu enfoque em relação à lei do valor, pois, como observa Belluzzo,

\begin{abstract}
A investigação marxista parte de uma pergunta muito diferente, e é impressionante que a maioria dos autores não tenha captado sua especificidade. Enquanto a indagação clássica parte do conceito abstrato do valor ${ }^{46}$, Marx simplesmente se pergunta em que condições os produtos do trabalho humano assumem a forma-valor ${ }^{47}$.
\end{abstract}

\footnotetext{
${ }^{44}$ Grespan, 1998. p. 28.

${ }^{45}$ Com destaque para os textos iniciais como o Manifesto, a Crítica da Filosofia do Direito de Hegel e a Ideologia Alemã. Nestes textos o que se pode encontrar é um destaque para as explicações mais gerais sobre o desenvolvimento histórico, explicações que dão grande destaque para a continuidade e quase se isentam de explicar a ruptura. Segundo Ellen Wood, “....no intervalo entre German Ideology e $O$ Capital, tendo como marco crítico Os Grundrisse, ocorreu uma mudança radical. A partir de então, Marx recusou-se a admitir como pressuposto o que reclamava explicação, inclinando-se cada vez mais a insistir na especificidade do capitalismo e de sua leis de movimento, e isso o forçou a reconhecer que o estabelecimento dessa dinâmica característica não podia ser aceita sem crítica. (Wood, 2003, p. 131)

${ }^{46}$ Muitos críticos do marxismo não assumem a perspectiva do valor como conceito abstrato (a exemplo do faziam os clássicos), mas criticam Marx imaginando que ele o faça, não compreendendo a forma específica como Marx trata o problema do valor. Sobre isso conferir Fausto, 1987, principalmente o capítulo 3.

${ }^{47}$ Belluzzo, 1987, p. 77 (grifos meus). A mesma posição é assumida por Harvey, para quem Marx "está mais diretamente interessado em fazer esta pergunta: como e por que assume o trabalho sob o capitalismo a forma que adota?" (1990, p. 48).
} 
Esta pergunta não é de fácil resposta, mas a busca por respondê-la é de grande importância para identificar a especificidade do capitalismo. Podemos dizer que está aí uma problemática que gira em torno de duas questões. A primeira sobre a validade da lei do valor antes e durante o capitalismo. A segunda sobre o significado de sua validade ou invalidade para o entendimento das relações sociais propriamente capitalistas.

Mas é importante observar, desde já, que a resposta à primeira questão não pode se dar em termos simples e diretos como, "a lei do valor só vale antes do capitalismo" ou "a lei do valor só vale no capitalismo". Ambas estão incorretas. Na verdade só é possível dizer que a lei do valor vale na sociedade mercantil simples como descrita por Marx na seção I de $O$ Capital. E isto cria uma grande dificuldade, pois envolve o questionamento sobre a relação entre esta seção e o restante do livro. Para alguns, o que Marx descreve ali não é a sociedade capitalista, justamente pela falta de seus elementos fundamentais, principalmente a ausência da valorização. Para outros, a sociedade ali descrita por Marx é, sim capitalista, por exemplo devido à validade da lei do valor ali presente, a qual não pode ser atribuída a sociedades pré-capitalistas. Novamente a resposta simples (sociedade descrita na seção I é capitalista ou a sociedade descrita na seção I não capitalista) é impossível. Mas então como responder a estas duas perguntas? Seguindo as idéias de Fausto (1987), à primeira poderíamos responder que antes do capitalismo o valor está pressuposto e que na seção I ele está posto. Em relação à seção I poderíamos dizer que ela é a aparência do capitalismo, aparência que no restante do livro é negada. Porém, como esta negação envolve a conservação do que foi negado, a seção I é também o capitalismo, apesar de sê-lo pondo aquilo que o capitalismo nega. Mas, afinal, o que capitalismo nega e a seção I põe? Justamente o valor.

A seguir procurarei expor algumas reflexões acerca destas duas respostas necessariamente interligadas. Para isso vou me basear nas idéias de Ruy Fausto, mas isso não significa que esteja pretendendo seguir o rigor lógico que este autor exige. Da mesma forma, não significa que pretendo permanecer nos limites da discussão da lógica dos textos de Marx. Ao contrário, meu objetivo - que reconheço como um tanto arriscado - é passar de uma reflexão inicialmente conceitual para alcançar algumas conclusões sobre a efetividade dos fundamentos do capitalismo a exemplo da discussão realizada no capítulo 1 sobre as idéias de Ellen Wood. Ou seja, a proposta para os próximos parágrafos é fazer um fechamento conclusivo destes três primeiros capítulos. Vejamos até onde isso é possível. 
Bem, para começar vamos ver a questão da posição do valor. Antes do capitalismo o valor já está pressuposto porque a produção de mercadorias é anterior ao capitalismo. Sobre isso é interessante lembrar, a exemplo do que faz Fausto, os comentários de Marx sobre a proximidade a que Aristóteles chegou de vislumbrar o valor ao entender que entre duas mercadorias trocadas há algo comum. Para Marx, ele só não chegou a identificar este algo comum como o trabalho porque o trabalho que ali predominava era escravo e, desta forma, não estava posta a igualdade entre os trabalhos dos homens de forma que eles pudessem ser comensuráveis ${ }^{48}$. Mas se esta igualdade não estava posta, é justamente porque o valor não estava posto, uma vez que é a posição do valor que promove a igualdade entre os trabalhos concretos.

$\mathrm{Na}$ verdade é bem razoável imaginarmos que ao longo da história as mercadorias tenham sido trocadas em proporções que se aproximavam do trabalho despendido para produzi-las. No entanto, é preciso lembrar que o valor das mercadorias no capitalismo não é definido pelo trabalho despendido para produzi-las e sim pelo tempo de trabalho socialmente necessário para produzi-las e isto faz toda a diferença. $\mathrm{O}$ ponto central desta diferença tem a ver com o seguinte trecho de Ruy Fausto;

O valor antes do capitalismo tem um estatuto análogo ao de um ser
qualquer no nível de sua pré-história. No nível de sua pré-história um
ser não existe enquanto sujeito, uma pré-história é, justamente, a história de seu surgimento enquanto sujeito ${ }^{49}$.

Antes do capitalismo o valor está pressuposto e não posto, justamente porque ele ainda não se tornou sujeito. Neste momento as mercadorias são trocadas por algo próximo ao seu valor, isto é, as mercadorias são trocadas pelos "seus valores", mas estes valores não são determinados pelo que é propriamente o valor, isto é, pelo tempo de trabalho socialmente necessário. Apenas quando o valor está posto, isto é, quando o valor das mercadorias é definido não mais pelo trabalho que foi despendido para produzir cada uma delas e sim por um parâmetro social de produtividade, ou seja pelo tempo de trabalho

\footnotetext{
${ }^{48}$ Mesmo assim é interessante notar que Ellen Wood chama a atenção para a criação do trabalho livre na Grécia Antiga, mesmo com a permanência da predominância do trabalho escravo. E além do mais segundo essa autora, "essa formação [do trabalhador livre em Atenas] única está no centro de grande parte do que caracteriza a polis grega e especialmente a democracia ateniense. Raros desenvolvimentos políticos e culturais em Atenas não foram de alguma forma afetados por ela [...]. As tradições políticas e culturais da Antiguidade Clássica que chegaram até nós estão, portanto, imbuídas do espírito do cidadão trabalhador..." (Wood, 2003, p. 157). ${ }^{49}$ Fausto, 1987, p. 113.
} 
socialmente necessário é que se pode dizer que o valor se tornou realmente substância do valor de todas as mercadorias. E isto só acontece na seção I de $O$ Capital.

Esta afirmação pode parecer descabida. Afinal, se Fausto afirmou que antes do capitalismo o valor não é sujeito, ele parece estar sugerindo que no capitalismo ele o é. E se pegarmos a seção I realmente encontraremos o valor como sujeito. O problema é que a seção I é apenas a aparência do capitalismo e no restante do livro, conforme as determinações do capital forem sendo acrescentadas, esta aparência será cada vez mais intensamente negada. Para compreendermos melhor este movimento façamos algumas observações sobre a maneira como Marx entende e expõe seus conceitos. Já vimos que há, em $O$ Capital, um método de exposição segundo o qual se caminha do abstrato ao concreto, sobre isso vejamos o seguinte trecho de Grespan;

$O$ projeto marxiano de apresentação depende de que se apreenda o fundamento da economia capitalista - o valor e o capital enquanto valor que se valoriza - como algo contraditório, gerando daí um processo pelo qual a contradição se desenvolve para abarcar o conjunto das relações econômicas como uma totalidade na qual cada forma se liga à outra como forma de manifestação da contradição todoabrangente. É neste ponto que Marx se aproxima do conceito hegeliano de exposição, ao mesmo tempo em que busca se desembaraçar dos elementos idealistas que a exposição implicaria na filosofia especulativa de Hegel, para afirmar a possibilidade de uma dialética materialista ${ }^{50}$.

Dessa forma, o caminhar do abstrato ao concreto durante a exposição promovida por Marx é um processo pelo qual vão se expondo as determinações do conceito de capital, até que ele esteja, ao final do processo, completamente determinado em sua concretude (como conjunto das múltiplas determinações). Este é também o movimento que procurei fazer no presente capítulo, expondo tanto o que chamei de abstração da riqueza como a problemática da crise de forma a ir aos poucos inserindo novas determinações até o ponto que tanto o capital como a crise estivessem, na medida do possível, determinados. Mas como chama nossa atenção Fausto, "para Hegel e Marx o conjunto das determinações não esgota o conceito. Mesmo plenamente determinado o conceito não é ele próprio se não for

\footnotetext{
${ }^{50}$ Grespan, 1998, p.35. (grifos meus)
} 


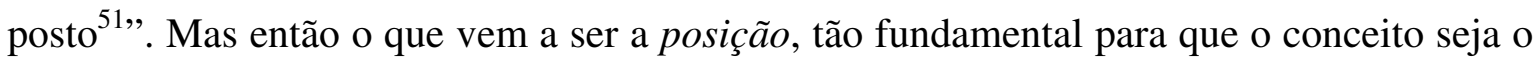
que ele é? Vejamos este trecho de Fausto;

\begin{abstract}
Marx supõe que a posição da coisa - e a posição da coisa é a existência (social) da coisa - é essencial para que ela seja o que é. Para que o "valor" (tempo de trabalho, trabalho como generalidade abstrata) seja valor (ou o "trabalho abstrato" 52 seja trabalho abstrato) é necessário que, além dessas determinações, haja posição, ou que essas determinações sejam determinações postas, socialmente existentes ${ }^{53}$.
\end{abstract}

Porém, uma dificuldade é que a passagem do pressuposto ao posto não é apenas um passar a existir do valor. É, na realidade, um passar a existir de algo que nega seus pressupostos. Mas note-se, nega no sentido dialético. Isto é, nega mantendo-os como seus pressupostos. A função da seção I no todo da obra é, justamente, demonstrar esta negação. Pelo menos é o que podemos entender a partir do seguinte trecho de Fausto, no qual ele está se referindo à opção de Marx por começar com a análise da mercadoria;

\begin{abstract}
As pressuposições e o ponto de partida são sem dúvida algo dado como é de resto o caso em qualquer apresentação dialética, a qual não deve começar nem por princípios ou fundamentos dedutivos, nem por verdades empíricas. Mas tais dados serão desenvolvidos, mais do que isto, serão negados, o que não quer dizer que eles sejam pontos de partida provisórios. A apresentação dialética é a passagem da aparência à essência, mas a aparência permanece como aparência [negada] ${ }^{54}$.
\end{abstract}

Tentemos entender o que se dá no texto de Marx e, ao mesmo tempo na história ${ }^{55}$, mas antes deixemos clara a diferença entre estes dois âmbitos. A descrição da sociedade mercantil simples feita na seção I não se refere a uma sociedade pré-capitalista que tenha efetivamente existido. Em primeiro lugar ela não poderia ser caracterizada como précapitalista porque o valor está posto ali. O fato de o valor estar posto, em termos históricos, significa que a concorrência entre os diversos capitais particulares de diferentes setores já deveria ser intensa o suficiente para efetivar o tempo de trabalho socialmente necessário

\footnotetext{
${ }^{51}$ Fausto, 1987, p. 106. (grifos meus)

${ }^{52}$ Fausto usa as aspas neste caso para diferenciar o conceito determinado, mas não posto, do conceito posto.

${ }^{53}$ Fausto, 1987, p. 105. (grifos meus)

${ }^{54}$ Fausto, 1987, p. 145

${ }^{55}$ Afinal, como nos lembra Grespan, "embora o objeto de O Capital não seja uma narrativa histórica, suas categorias têm como referência um objeto histórico constituído de modo que muitas vezes as passagens da apresentação dependem de pressupostos históricos, evidenciando a impossibilidade de uma mera dedução lógica dos conceitos". (Grespan, 1998, p. 38).
} 
como substância de valor das mercadorias. Esta não pode ser a realidade de uma sociedade pré-capitalista. Em segundo lugar, os produtores das mercadorias como descritos ali são irreais. Todos são produtores-proprietários. Nas sociedades mercantis pré-capitalistas (assim como na relação entre o núcleo capitalista e as periferias não propriamente capitalistas da economia mundial do século XVI em diante) as mercadorias eram, em geral, produzidas com mão de obra escrava ou nas várias formas de servidão. Por sua vez, no capitalismo a mão de obra, como se sabe, é majoritariamente assalariada, sendo esta condição, inclusive, uma das bases do capitalismo.

O que existe na seção I, portanto, é a descrição de algumas características do capitalismo, a mercadoria e o dinheiro. Na base desta descrição está a teoria do valor, segundo a qual entendemos o que é o valor das mercadorias e como a troca entre mercadorias se desdobra na gênese do dinheiro. No entanto, tudo que existe na seção I está baseado no pressuposto de que as mercadorias se trocam pelos seus valores e este pressuposto é posteriormente negado. Mas esta negação não é uma negação absoluta. Da mesma forma como não é uma negação promovida por um elemento exterior aos pressupostos ali estabelecidos. É disto que trata o seguinte trecho de Belluzzo;

\begin{abstract}
Adam Smith, ao considerar este tipo de sociedade [de produtores independentes], "o estado rude e primitivo", atribuiu-lhe um caráter de naturalidade que, na verdade, não possui. E, ao fazê-lo não foi capaz de perceber as conseqüências provocadas pela separação dos produtores diretos dos meios de produção. Isto é, não foi capaz de compreender que esta separação, de um lado, já existe "em potência” na sociedade mercantil simples e, de outra parte, que implica na generalização da produção mercantil, uma exacerbação do fenômeno da troca que culmina com a transformação da força de trabalho em mercadoria e dos meios de produção em capital ${ }^{56}$.
\end{abstract}

$\mathrm{Na}$ sociedade de produtores independentes imaginada por Adam Smith as mercadorias são produzidas pelos próprios proprietários dos meios de produção a exemplo do que ocorre na seção I de $O$ Capital. Adam Smith e os outros clássicos, no entanto, imaginavam que uma sociedade como esta existia realmente. Ou melhor, imaginavam que

\footnotetext{
${ }^{56}$ Belluzzo, 1997, p. 83.
} 
as trocas de mercadorias sempre tivessem sido regidas pela lei do valor. E, além do mais que continuassem sendo na sociedade capitalista ${ }^{57}$.

Ao contrário, em Marx, a descrição da sociedade mercantil simples já pressupõe que a troca entre mercadorias com base no tempo de trabalho socialmente necessário só pode ocorrer em condições sociais bastante específicas. Condições nas quais os diversos trabalhos concretos são reduzidos ao trabalho abstrato, o que só pode se dar numa sociedade na qual as relações de mercado já tenham levado a uma autonomização da troca em relação à produção. Ou seja, uma sociedade na qual a produção de riqueza já é intermediada pelo processo de troca. Na realidade por uma "exacerbação do processo de troca que transforma a força de trabalho em mercadoria e os meios de produção em capital". Mas, afinal, o que significam estas duas transformações? Bem, digamos que elas exprimem, justamente, aquilo que muitos não percebem, uma vez que,

Embriagados pela convicção positiva de que "um escravo negro é um homem de raça negra", sequer acode à imaginação de críticos e comentadores como a generalização da produção mercantil possa implicar na transfiguração da lei do valor em lei do processo de valorização. E esta transfiguração não é o resultado de um hábil jogo conceitual, senão decorre da metamorfose das relações entre produtores independentes de mercadorias, relações que se expressam através do valor, o que, portanto, determina uma transformação na própria forma do valor expressar essas relações. Nesta perspectiva, ainda que o regime capitalista de apropriação pareça romper abertamente com as leis originárias da produção de mercadorias, não surge, em qualquer sentido, da violação dessas leis, senão, pelo contrário, de sua aplicação ${ }^{58}$.

A força de trabalho assumindo a forma de mercadoria não significa outra coisa senão que ela passará a ser vendida. Mas como vimos, se o valor de troca da força de trabalho é o salário do trabalhador seu valor de uso não é outro senão o de produzir mais valor do que recebe, isto é, produzir mais-valia. Por sua vez, a transformação do capital em

\footnotetext{
${ }^{57}$ Há, como se sabe, contradições (mas estas apenas no âmbito das idéias) no pensamento de Adam Smith quando este tenta transpor a teoria do valor para a sociedade capitalista. O melhor exemplo é, justamente, a questão da origem do excedente. Neste caso Smith chega bastante próximo da idéia de mais-valia, mas recai na concepção de que a renda, o salário e o lucro são simplesmente a remuneração da terra, do trabalho e do capital, o que, por sinal, lhe possibilita manter a lei do valor intacta. Sobre a lei do valor na concepção dos clássicos é interessante o Capítulo 1 de Belluzzo (1987).

${ }^{58}$ Belluzzo, 1987, p. 88
} 
meios de produção tem dois significados importantes. O primeiro é que a propriedade destes meios de produção é a condição para que os compradores de força de trabalho possam consumir esta mercadoria tão especial de modo a produzir mais riqueza do que despenderam ao adquiri-la. O segundo, é que o sentido da existência destes meios de produção não é mais o de serem usados para a produção de coisas, mas sim o de serem usados para a produção de riqueza abstrata.

Estas duas transformações exprimem, portanto, a transfiguração da lei do valor em lei do processo de valorização. As mercadorias já não são produzidas meramente para serem trocadas. São produzidas para promoverem a valorização. A exacerbação do processo da troca, neste sentido, promove a passagem da troca simples para a troca propriamente capitalista, que é a troca que põe a exigência da valorização do valor. Mas o interessante é que esta transfiguração que começa a ser percebida no texto de Marx quando este analisa a transformação do dinheiro em capital (capítulo IV do livro 1, ou seja, primeiro capítulo após a seção I) já está pressuposta na seção I, justamente na figura do dinheiro como equivalente geral. Como vimos, o percurso conceitual de dedução da forma dinheiro demonstra um processo de autonomização do dinheiro, isto é, um processo de autonomização do valor como riqueza abstrata. Com certeza não é à toa que imediatamente após a conclusão do argumento sobre a gênese ${ }^{59}$ do dinheiro Marx inicia sua exposição sobre o fetichismo da mercadoria.

Mas a transfiguração da lei do valor em lei do processo de valorização não é uma substituição de uma por outra e sim uma negação dialética. A lei do valor é negada e, ao mesmo tempo conservada. Isto se mostra no fato de que o processo de valorização, como vimos, está baseado na troca de equivalentes. A troca da mercadoria força de trabalho pelo tempo de trabalho socialmente necessário para produzi-la, isto é, seu salário. É neste sentido que Belluzzo argumenta a seguir.

A permanência da lei do valor se apresenta, portanto, para o capital em seu conjunto - enquanto realização de seu conceito (valor que se valoriza sugando trabalho vivo) - como norma inviolável de existência, ao mesmo tempo em que a violação dessa norma aparece para cada

\footnotetext{
${ }^{59}$ Não custa lembrar que a gênese de um ser, segundo Ruy Fausto, é o percurso deste ser em sua pré-história, que, como vimos, constitui a posição do ser como sujeito.
} 
capitalista individual, no processo de competição, como condição de sobrevivência ${ }^{60}$.

O capital depende da permanência da lei do valor para que possa, enquanto trabalho morto, sugar trabalho vivo garantindo a valorização. Este procedimento só é possível pela separação entre os produtores diretos e os meios de produção. É graças a tal separação que o trabalhador vende a sua mercadoria força de trabalho - pelo seu valor de troca - para o capitalista, que deverá consumi-la de forma a gerar não apenas valor, mas um valor maior do que aquele pago ao trabalhador pela força de trabalho, isto é, mais-valia. O interessante é entendermos que esta separação não é outra coisa senão a alienação. O que se dá no processo de produção propriamente capitalista é que ao trabalhador cabe, apenas, fornecer a força de trabalho, enquanto ao capitalista cabe fazer com que o consumo desta força de trabalho pelos meios de produção (e repare-se que sujeito e objeto nesta frase não estão numa inversão sintática, mas sim real) forneça o resultado mais produtivo possível, de modo a garantir que seja produzida a mais-valia. Mas note-se que a alienação que aí existe é um processo muito mais amplo do que a divisão da sociedade entre proprietários e nãoproprietários dos meios de produção. Justamente porque ela envolve a ambos. Para falar dela, retomemos o trecho de Belluzzo referente à nota 102 [conferir]. Ali o autor afirmava que Adam Smith,

... não foi capaz de compreender que esta separação [entre os produtores diretos e os meios de produção], de um lado, já existe "em potência" na sociedade mercantil simples e, de outra parte, que implica na generalização da produção mercantil, uma exacerbação do fenômeno da troca que culmina com a transformação da força de trabalho em mercadoria e dos meios de produção em capital.

A priori pode parecer estranho imaginar que a separação entre produtores diretos e meios de produção possa existir em potência na sociedade mercantil simples, posto que ali, os produtores são claramente produtores-proprietários. Mas o que se deve entender é que esta separação é, justamente, a alienação à qual os produtores estão submetidos mesmo na condição de proprietários. Já na sociedade mercantil simples (e com isso não restam dúvidas sobre Marx estar ou não se referindo ao capitalismo ali) os produtores diretos, mesmo sendo proprietários dos meios de produção têm de fazer com que a sua própria

${ }^{60}$ Belluzzo, 1987, p. 100. 
força de trabalho seja consumida por estes meios de produção de acordo com um parâmetro social de produtividade, afinal, as mercadorias por eles produzidas serão trocadas não de acordo com o trabalho gasto em sua produção, mas sim de acordo com o tempo de trabalho socialmente necessário. E é esta mesma separação, que existia em potência na sociedade mercantil simples, que acaba implicando na generalização da produção mercantil e, com isso, na transformação da força de trabalho em mercadoria e dos meios de produção em capital.

No percurso conceitual de Marx não há a pretensão de se contar a história do capitalismo e neste sentido seria um equívoco imaginar que elementos descritos na seção I são historicamente anteriores a outros do restante do livro. Portanto, quando dizemos que a separação entre produtores diretos e meios de produção já estava presente em potência na seção I, não se deve entender que ela existia em sociedades anteriores ao capitalismo e, posteriormente, foi se generalizando. A meu ver não é isto que Belluzzo está afirmando, mas sim que o processo social fundamental (justamente como fundamento do capitalismo) que leva à instauração das relações sociais capitalistas não é a transformação dos meios de produção em capital e da força de trabalho em mercadoria. Estas duas transformações são, isso sim, conseqüências daquela separação que existia em potência na sociedade mercantil simples porque é ali que Marx põe o fundamento do capitalismo.

Com isso é inevitável um curto retorno à análise de um aspecto das idéias de Ellen Wood. Mas note-se que com o que virá não estarei afirmando que a sociedade analisada por Wood é a sociedade mercantil simples. Neste momento, acredito ser correta uma analogia entre a metodologia historiográfica de Wood e a apresentação categorial de Marx, no sentido de que em ambos os casos há uma busca por identificar o fundamento das relações sociais propriamente capitalistas. Com esta perspectiva é que devemos voltar ao pensamento de Wood.

A origem do capitalismo, como foi apresentada no capítulo 1 na minha interpretação das idéias de Wood, estaria ligada à generalização das forças de mercado enquanto coações que teriam levado os produtores à necessária busca do lucro por meio da maximização da produtividade do trabalho. Segundo esta tese o nascimento do capitalismo estaria ligado ao campo e não à cidade como é mais comumente estabelecido na historiografia em geral. A tese do capitalismo agrário pode enfrentar alguns 
questionamentos, dentre os quais a própria Ellen Wood apresenta a ausência, ou pelo menos a escassez, do trabalho assalariado no campo inglês naquela época.

O problema é que o trabalho assalariado é, reconhecidamente, um dos fundamentos intrínsecos ao capitalismo, através do qual é possível a produção da mais-valia, fundamento da valorização do capital. Mas a tese do capitalismo agrário acaba afirmando que o capitalismo teria nascido antes do trabalho assalariado, isto é, o capitalismo teria surgido antes do surgimento de um de seus principais fundamentos. Daí vem, necessariamente a pergunta sobre a validade de se caracterizar o período tratado por Wood como propriamente capitalista. Ou, pondo de outra forma, poder-se-ia perguntar se a origem do capitalismo não estaria, portanto, um pouco mais à frente na história, talvez no século XVIII, quando o trabalho assalariado já estava generalizado na Inglaterra.

No entanto, não considero a possibilidade de encontrarmos descontinuidades absolutas na história que possam afirmar que em certo ponto estaria a origem propriamente dita deste ou daquele fenômeno social. O que importa não é encontrar o ponto correto da origem, mas sim o fundamento correto do fenômeno que está sendo analisado.

É por isso que a autora argumenta que a mudança na estrutura de propriedade teria sido o motor principal do processo de proletarização e, posteriormente, da industrialização. Neste caso, ao invés da existência do trabalhador assalariado ter gerado as condições capitalistas de produção, seriam estas que teriam criado o trabalhador assalariado ${ }^{61}$.

Poderia-se dizer que a hipótese da proletarização ser mais um produto que uma condição para o surgimento do capitalismo parece muito estática e, talvez, pouco dialética, posto que uma coisa deveria ser vista como produto e, ao mesmo tempo, condição da outra. No entanto, o risco de reducionismo talvez valha a pena neste caso, uma vez que ao pôr a mudança da estrutura de propriedade como origem do capitalismo, Wood chama a atenção não para "o ponto no qual tudo começou", mas sim para o fundamento do processo que resulta de tal mudança. Se virmos esta mudança como o início do capitalismo, temos que ver o fundamento deste mais ligado ao processo de alienação - que a imposição das relações do mercado propriamente capitalista representou para o conjunto da sociedade - e nem tanto como a luta de classes entre capitalistas e proletários. Se esta hipótese pode parecer para alguns pouco marxista (posto que parece pôr a luta de classes em segundo

\footnotetext{
${ }^{61}$ Wood, 2001, p.111
} 
plano para o entendimento do capitalismo) voltemos à análise do percurso conceitual de Marx.

Se a seção I tem a função de pôr aquilo que o capitalismo nega, é possível entender que, com isso, ela nos dê a dimensão real da alienação, fundamental para compreendermos todo o restante do livro. Ou seja, ela coloca a alienação como o fundamento que se desdobra em todo o restante da obra. Sobre isso, relembremos um trecho de Grespan já citado.

O projeto marxiano de apresentação depende de que se apreenda o fundamento da economia capitalista - o valor e o capital enquanto valor que se valoriza - como algo contraditório, gerando daí um processo pelo qual a contradição se desenvolve para abarcar o conjunto das relações econômicas como uma totalidade na qual cada forma se liga à outra como forma de manifestação da contradição todoabrangente.

Da mesma forma como o método historiográfico de Wood ao buscar a origem social do capitalismo encontra a alienação em relação ao mercado, no método de apresentação categorial de Marx, encontramos desde o início esta mesma alienação posta como a cisão própria à mercadoria que, no caso, representa a contradição fundamental da economia capitalista ${ }^{62}$. Ao longo do livro esta contradição vai se desdobrando para abranger a totalidade das relações econômicas.

Como já tratamos nos itens $3.1,3.2$ e 3.3 de diversas formas podemos verificar que a riqueza propriamente capitalista é marcada pela separação entre sua produção e sua realização. Separação esta que tem como mediação a troca propriamente capitalista. Isto se pode perceber muito bem na idéia de que o valor que se põe na seção I é negado no restante de $O$ Capital. Colocando a questão de forma mais explícita, poderíamos dizer que se na seção I a alienação já existe em potência, conforme vai se cumprindo o projeto de apresentação categorial ela vai se tornando cada vez mais concreta até se pôr no livro 3. Este processo de concreção da alienação se dá por meio da negação do valor e a posição da

\footnotetext{
${ }^{62}$ Neste caso, é preciso lembrar que esta cisão própria à mercadoria tem a mesma forma de existência da cisão que o mercado propriamente capitalista impõe ao processo de produção e realização da riqueza, isto é, em ambos os casos temos uma cisão que impõe a necessidade da reunificação. Quando esta não acontece temos a manifestação desta necessidade na forma violenta da crise.
} 
alienação se dá na consideração do capital na forma efetiva de sua existência social, isto é, na forma de múltiplos capitais individuais concorrendo entre si. Vejamos como isso se dá.

Como chama a nossa atenção Belluzzo, se por um lado a lei do valor tem de se manter para o capital em geral como sua norma inviolável de existência, ao mesmo tempo, a violação dessa norma aparece para cada capitalista individual, no processo de competição, como condição de sobrevivência. $\mathrm{O}$ que faz, portando, com que a lei do valor seja negada, isto é, o que faz com que as mercadorias não possam ser trocadas pelo seu valor é, justamente, a competição, a concorrência. Isto se pode verificar primeiramente, já no livro 1 , na necessidade posta aos capitais individuais de buscarem a produção de maisvalia relativa para que os valores de suas mercadorias fiquem abaixo do valor social. Mas é, na transformação dos valores em preços de produção, conseqüentemente, da mais-valia em lucro, que este processo pode ser verificado em sua concretude, uma vez que,

A concorrência necessariamente leva cada capitalista a comportar-se de uma forma que ameaça a base mesma de sua reprodução social. Comportam-se assim porque a lógica do mercado os obriga a responder aos preços de produção mais do que aos requerimentos diretos para a produção de mais-valia. Esta é a idéia crucial que surge do estudo do problema da transformação ${ }^{63}$.

E por que este comportamento ameaça a base da reprodução social? Justamente, porque, como vimos, ele impõe aos capitalistas o aumento da produtividade do trabalho por meio da constante busca pelo aumento da composição orgânica do capital. É esta a fonte central das crises de sobreacumulação. Mas se é este comportamento o gerador das crises é ele também o motor do avanço das forças produtivas no capitalismo e é por isso que,

O fetichismo que provém de que os valores se transformem em preços de produção desempenha um papel fundamental no argumento de Marx. Este fetichismo realiza uma função ideológica e apologética óbvia, ao mesmo tempo em que mistifica a origem do lucro como mais-valia. Esta mistificação é perigosa para o capital porque a reprodução da classe capitalista depende por completo da criação e recriação de mais-valia; mas mesmo se os capitalistas pudessem penetrar por detrás desse

\footnotetext{
${ }^{63}$ Harvey, 1990, p. 78
} 
fetichismo de sua própria concepção, permaneceriam sendo incapazes de retificar uma situação potencialmente grave. A concorrência os obriga a repartir o trabalho social e rearranjar seus processos de produção de tal maneira que se iguale à taxa de lucro média ${ }^{64}$.

A função apologética da transformação dos valores em preços de produção é, justamente, a criação de uma situação na qual o lucro não depende imediatamente do quanto de mais-valia se produz em um determinado processo produtivo ligado a um capital individual específico. Ao contrário, este mesmo lucro é intermediado pelas condições do mercado propriamente capitalista de uma forma que o trabalho social seja dividido de acordo com a produtividade do trabalho e não de acordo com a produção de mais-valia. Esta é uma situação potencialmente grave porque a classe capitalista como um todo continua dependendo da produção de mais-valia, mas, ao mesmo tempo ao ser obrigada a aumentar continuamente o capital constante como forma de intensificar a produtividade do trabalho ela vai promovendo o estreitamente das bases sociais sobre as quais a mais-valia é produzida. Com isso podemos perceber que o fundamento do capital é justamente a alienação, tanto do proletário como do capitalista, afinal, como se pergunta Ruy Fausto;

Que é o capital, e que representam em relação a ele o operário e o capitalista? A resposta a esta questão nos conduz à problemática do sujeito e do predicado. O capital, diz, com efeito, o Capítulo 4 (original) do Tomo I de O Capital, é sujeito. [...] O operário e o capitalista são suportes desse sujeito, e num sentido (mais ontológico que lógico) seus predicados $^{65}$.

$\mathrm{Ou}$, ainda, para ir direto à fonte,

As funções que o capitalista exerce não são mais do que as funções do próprio capital personificado, (o capitalista) é o capital enquanto pessoa; do mesmo modo o operário funciona como trabalho personificado, (trabalho) que a ele pertence como suplício, como esforço, mas que pertence ao capitalista como substância criadora e incrementadora de riqueza [...] A dominação do capitalista sobre o operário é, por conseguinte, a dominação da coisa sobre o homem, a do trabalho morto sobre o trabalho vivo, a do produto sobre o produtor [...]

\footnotetext{
${ }^{64}$ Harvey, 1990, p. 78

${ }^{65}$ Fausto, 1987, p. 30
} 
Na produção material, no verdadeiro processo da vida social dá-se exatamente a mesma relação que acontece na religião, no terreno ideológico: a conversão do sujeito em objeto e vive-versa ${ }^{66}$.

Nos estágios iniciais da apresentação categorial de Marx (como é o caso do trecho citado imediatamente acima) este domínio do capital sobre o capitalista e o operário pode parecer uma construção muito idealista. Mas se considerarmos o projeto de apresentação em sua totalidade, entendendo a determinação e a posição do capital podemos entender como este domínio do movimento autônomo que é o capital ocorre na realidade social. Ele ocorre por meio da concorrência, da maneira como explica Rosdolsky no trecho a seguir;

Ela [a concorrência] é, ao mesmo tempo, “a relação do capital consigo mesmo como outro capital, ou seja, o comportamento real do capital na condição de capital". Só "através dela aparece como necessidade externa, para cada capital, aquilo que corresponde [...] ao conceito de capital". Por isso, conceitualmente, a concorrência expressa a "natureza interna do capital [...] que se apresenta e se realiza como ação recíproca dos diversos capitais entre si”, os quais "impõe a si próprios as determinações imanentes do capital "67.

Para Belluzzo a fragmentação do capital em capitais individuais, e seu papel na efetivação da lógica do capital nos leva a entender que "submissão do trabalho, autonomização da estrutura técnica e, portanto, reversão das potencialidades do trabalho ao capital estabelecem a dominância da concorrência entre capitais sobre as relações entre capital e trabalho" ${ }^{68}$. Ou seja, a efetivação do capital está mais imediatamente determinada pela concorrência entre capitalistas do que pela luta de classes, mesmo que esta continue tendo um papel fundamental.

\footnotetext{
${ }^{66}$ Marx, 1985, p. 55.

${ }^{67}$ Rosdolsky, 2001, p. 50. Os trechos entre aspas são citações dos Grundrisses.

${ }^{68}$ Belluzzo, 1987, p. 109.
} 


\section{Segundo Excurso sobre encontros e desencontros metodológicos}

Nos dois capítulos anteriores me dediquei à exposição de reflexões acerca do pensamento de um grupo de autores que discutiram a teoria econômica de Marx. Como observei no Primeiro Excurso, o enfoque de tais autores se limita à análise dos textos de Marx e de alguns marxistas, o que nos permite classificá-los como estudos de teoria marxista. Ao mesmo tempo, um dos autores considerados - David Harvey - apesar de também fazer uma discussão teórica dos textos de Marx é caracterizado por uma tentativa de ir além de tal discussão. Esta observação não se pretende uma crítica àqueles estudos teóricos, e sim uma constatação de que são dois enfoques diferentes. O enfoque da análise teórica do pensamento de Marx é indispensável para que se entenda com precisão do que trata este autor, procurando assim evitar as interpretações vulgares que tanto marcaram a tradição marxista. Desta forma, este tipo de estudo jamais pode ser preterido em nome de análises digamos mais empíricas ou mais históricas da realidade capitalista. Por outro lado - a não ser que se tenha como objetivo estudar teoricamente a obra de Marx (a exemplo do que fazem Fausto, Grespan, Belluzzo e muitos outros) - em estudos que pretendam se apoiar nesta obra para decifrar a realidade do capitalismo de nossos dias, sem dúvida é preciso superar Marx.

Nos próximos capítulos muitos dos autores considerados adotam de diferentes maneiras a perspectiva de superação do pensamento de Marx o que acaba dando, desta forma, o tom do que seguirá. Mas antes de adentrarmos nesta última parte do trabalho é importante que se entenda com mais precisão do que se trata esta superação. Sobre isso, um curto apontamento já foi feito no Primeiro Excurso, quando afirmei que a superação do pensamento de Marx deveria ser como a Aufhebung hegeliana, isto é, uma superação que conserva o que foi superado. Mas vejamos mais concretamente o que significa isso no contexto do presente trabalho.

A obra econômica de Marx é marcada por uma escolha fundamental, qual seja, concentrar-se na lógica do capital como se ela fosse a mediação universal nas relações de poder que possibilitam a alguns controlarem o trabalho de outros. Isso, claro, para as sociedades nas quais dominem as relações de produção capitalistas. Assim sendo, não fazem parte das preocupações de Marx possíveis usos de métodos não econômicos para a efetivação do poder de classe. No caso de $O$ Capital a grande (e importante) exceção é o capítulo sobre a acumulação primitiva, mas isso é claro porque, a priori, esta forma de acumulação aparece na obra como o processo pelo qual as relações de produção 
capitalistas passam a ser dominantes numa dada sociedade. Depois desta transição a lógica do capital se destaca como o principal nexo das relações de poder e, por isso, deve ser analisada em sua especificidade ${ }^{1}$.

É preciso destacar, no entanto, que à época de Marx a universalidade da lógica do capital como mediação para as relações de dominação não parecia ser uma realidade. Em todo o mundo (mesmo na Europa) poder-se-ia encontrar formas não puramente econômicas de extração do excedente nas relações de trabalho, fora o fato de que as principais potências econômicas do mundo utilizavam-se de métodos não econômicos para garantir o escoamento de suas mercadorias mundo afora. Há, portanto, um desencontro ao menos aparente - entre a escolha de Marx em concentrar-se na lógica do capital como a forma universal de dominação e a realidade de sua época. Sobre tal desencontro podemos levantar duas hipóteses.

A primeira seria a de que, mesmo consciente da não universalidade da dominância do capital naquele momento, Marx está considerando a universalização das relações capitalistas como uma tendência a se realizar num crescente necessário. Cada vez mais a lógica do capital dominaria as relações sociais, substituindo formas não capitalistas de mediação até o ponto que toda a estrutura social fosse determinada pelo capital. Assim sendo, a discussão feita na obra econômica de Marx seria suficiente para explicar todos os nexos das sociedades capitalistas. A meu ver só duas posturas em relação ao pensamento de Marx levam a sério esta hipótese. Uma delas é aquela que procura rejeitar este pensamento tachando-o de teleológico e determinista. Teleológico por acreditar numa tendência histórica crescente e irreversível. Determinista por acreditar que a lógica do capital poderia determinar todos os outros âmbitos da socialização. A outra postura é aquela que como chama nossa atenção Holloway (2003), fetichiza o pensamento de Marx não permitindo qualquer relativização ou para usar o termo adequado, nenhuma dialetização deste pensamento.

\footnotetext{
${ }^{1}$ Para Harvey (2004) e Grespan (1998) os pressupostos de Marx são bastante próximos dos da economia política clássica, nas palavras de Harvey, tais pressupostos são: "mercados competitivos de livre funcionamento com arranjos institucionais de propriedade privada, individualismo jurídico, liberdade de contrato e estruturas legais e governamentais apropriadas, garantidas por um Estado 'facilitador' que também garante a integridade da moeda como estoque de valor e meio de circulação. O papel do capitalista como produtor e comerciante de mercadorias já está bem estabelecido, e a força de trabalho tornou-se uma mercadoria trocada pelo seu valor apropriado. A acumulação 'primitiva' ou 'original', e seu processo agora tem a forma de reprodução expandida (embora mediante a exploração do trabalho vivo na produção) em condições de 'paz, prosperidade e igualdade'. (2004, página 120).
} 
A segunda hipótese é a de que Marx considera de forma isolada a lógica do capital para apreender sua especificidade. Isso não significa que outras lógicas de dominação não existissem naquela época ou que não existam atualmente, mas apenas que estas outras lógicas estão em relação direta com a mediação do capital. Assim sendo para começar é preciso se evitar qualquer forma de teleologia. Alguns podem questionar afirmando que em textos do próprio Marx - como no Manifesto, por exemplo - a teleologia aparece claramente. A resposta a tal questionamento seria justamente a proposta de se superar o pensamento de Marx conservando aquilo que muitos chamam de seu núcleo dialético e não fetichizá-lo como se fosse um texto sagrado ao qual teríamos que nos remeter sempre que quiséssemos adquirir legitimidade. Mas para retornar à questão principal, evitar qualquer forma de teleologia significa, principalmente, compreender que não há uma tendência de eliminação de todas as formas não capitalistas de mediação e de dominação. Ao contrário, é importante perceber que a convivência de formas capitalistas com outras não capitalistas não é exclusividade da época de Marx, sendo esta também a realidade de nossos dias.

Como se sabe há esta perspectiva na tradição marxista desde os textos de Lênin e Rosa Luxemburgo, mas mesmo estes clássicos estão embebidos em pressupostos teleológicos ligados às perspectivas políticas de sua época. Neste sentido, a convivência de formas capitalistas e não capitalistas de dominação aparecia na maioria das vezes como algo passageiro ou próprio das margens do sistema capitalista ${ }^{2}$, como era o caso da escravidão no Brasil ou do Imperialismo europeu na África e na Ásia. Uma hora ou outra estas formas seriam eliminadas, o que, na visão de Rosa, levaria ao fim do próprio capitalismo. Mas o questionamento à teleologia tem de ir além disso e é neste sentido que devemos considerar, para começar, o pensamento de Henri Lefebvre.

A obra de Lefebvre é bastante diversificada envolvendo desde análises dos pensamentos de Marx, Hegel e Nietzsche até suas reflexões sobre o mundo moderno e a sociedade urbana, passando por uma volumosa obra sobre o Estado. Em muitos de seus textos é possível apreender uma idéia mais complexa sobre a temporalidade das formas sociais. Uma perspectiva que procura evitar qualquer teleologia. Como chama nossa atenção Martins (1996), isso fica claro no uso que Lefebvre faz do conceito trabalhado, mas não levado à últimas consequiências, por Lênin, qual seja, o conceito de formação econômico-social. Este conceito em contraposição ao de modo de produção - o qual ganhou uma rigidez no pensamento marxista que não lhe era próprio no pensamento

\footnotetext{
${ }^{2}$ Cf. Holloway (2003, pág. 123) e Harvey (2004, pág. 120)
} 
marxiano - procura vislumbrar a convivência de diferentes temporalidades na sociedade capitalista, isto é, a convivência de relações sociais desigualmente datadas.

Em tempos de guerra (imperial) como este que estamos vivendo esta idéia é preciosa e a prova disto é a ascensão do debate sobre a permanência de formas de acumulação primitiva nas fases avançadas do capitalismo. Como veremos um grupo de autores (estrangeiros, como David Harvey, John Holloway, Daniel Bensaïd e Massimo De Angelis, ou nacionais como Paulo Arantes, Amélia Damiani e Francisco de Oliveira) vem se preocupando justamente com isso. O que é preciso destacar é que a idéia geral que perpassa estas reflexões é a de que o capitalismo, só se efetiva com a permanência de formas não capitalistas de acumulação. Esta perspectiva - que se procura seguir no presente trabalho - leva-nos a um grande ganho teórico para a superação do pensamento de Marx no que se refere ao entendimento da composição de diferentes lógicas na reprodução do poder de classe.

Porém, se por um lado, não se pode entender que os elementos não propriamente capitalistas de dominação tendem a ser eliminados pela crescente efetivação da lógica do capital, por outro não se pode trabalhar com a hipótese de que tais elementos sejam autônomos em relação a tal lógica. Se assim o fosse não se estaria promovendo uma superação do pensamento de Marx, mas, isto sim, sua refutação. E, com isso, os capítulos anteriores não teriam sentido nenhum neste trabalho. Ao invés disso, o sentido deles é, a meu ver, o mesmo que marca a opção de Marx por analisar em separado a lógica do capital, isto é, apreender a especificidade de uma determinação fundamental da sociedade moderna. Uma determinação que não é de modo algum autônoma, mas que, ao mesmo tempo, limita a autonomia das outras determinações ao se tornar a mediação para elas. Desta forma, as discussões que virão a seguir se apóiam, ao mesmo tempo em que procuram ultrapassar, as que precedem este excurso. 


\title{
4 - A separação além (ou aquém) da riqueza abstrata: a reprodução.
}

\author{
A forma dialética da exposição só é correta quando \\ reconhece seus próprios limites \\ Karl Marx. Grundrisses.
}

Se partimos, então, da idéia de que nosso grito não é o grito de uma vanguarda, mas o de um antagonismo que é inseparável do fato de viver em uma sociedade capitalista, de que é um grito universal (ou quase universal), então a dureza do fetichismo se dissolve e o fetichismo se revela como um processo de fetichização. Com isso, se dissolve a dureza de todas as categorias e os fenômenos que aparecem como coisas ou como fatos dados (como a mercadoria, o valor, o dinheiro, o Estado), se revelam também como processos. As formas assumem vida. As categorias se abrem para revelar que seus conteúdos são luta.

John Holloway, Mudar o Mundo sem Tomar o Poder.

A acumulação propriamente capitalista já foi aqui definida como acumulação de riqueza abstrata, entendida como a valorização do valor, dependente da intensificação da produtividade do trabalho. Se até aqui muitas páginas foram dedicadas à identificação das especificidades desta acumulação, uma das principais intenções foi poder diferenciá-la das outras formas - o que, por sua vez, mostrará o seu sentido mais à frente. Assim sendo, se àquela forma de acumulação estou chamando acumulação capitalista, por exclusão, às outras vou me referir, por enquanto, como formas de acumulação não capitalistas. Mas espero que esta denominação provisória não gere confusão. Não se deve entender que elas ocorram fora do capitalismo. Aliás, como veremos, elas não só ocorrem no interior do capitalismo como se dividem em tipos diferentes de formas não capitalistas conforme a maneira como se relacionam com a acumulação capitalista. Esta diferenciação será feita mais à frente, por enquanto é preciso discuti-las em seu sentido mais geral. 
Para começar, um ponto importante a ser esclarecido é o da origem antiga de certas formas de acumulação e sua existência no capitalismo. Para que não haja confusão, poderíamos chamar aquelas formas de extração de excedente que ocorreram em épocas anteriores ao capitalismo e não podem ser entendidas nem ao menos como formadoras deste, de formas de acumulação pré-capitalistas ${ }^{1}$, diferenciando-as assim das formas de acumulação não capitalistas que guardam alguma relação com o capitalismo. O problema é que estas últimas podem, muitas vezes, ser heranças de épocas passadas e isso pode criar ainda mais confusão. Neste sentido é preciso levar em conta o que diz Lefebvre no seguinte trecho;

um importante aspecto do problema teórico é o de conseguir situar as descontinuidades em relação às continuidades, e inversamente. Como existiriam descontinuidades absolutas sem continuidades subjacentes, sem suporte e sem processo inerente? Reciprocamente, como existiria continuidade sem crises, sem o aparecimento de elementos ou de relações novas? ${ }^{2}$

Considerando o devir histórico em termos de continuidades e descontinuidades é preciso entender que heranças de formas pré-capitalistas de acumulação não são uma aberração dentro do capitalismo, sendo, até mesmo, constantemente necessárias à reprodução deste último. Nem por isso, no entanto, podemos entender que tais heranças mantêm seu sentido original. Ao contrário, precisamos tentar identificar como ganham novo teor ao se relacionarem com as formas capitalistas de acumulação.

Mas se até a pouco a preocupação central foi definir as especificidades da acumulação capitalista, à frente é das formas não capitalistas de acumulação que me ocuparei. Para que a transição não seja muito brusca, segmentando mais do que o estritamente necessário o movimento do pensamento, vamos começar refletindo sobre as possíveis relações entre estas formas de acumulação. Nada melhor para iniciar do que darmos uma olhada num trecho do próprio Marx sobre o assunto.

\footnotetext{
${ }^{1}$ Refiro-me, por exemplo, à escravidão antiga, à servidão de épocas longínquas ou às diversas formas de domínio dos antigos impérios teocráticos. Aqui o termo acumulação pode ser bastante questionado uma vez que antes do capitalismo a acumulação de riqueza não era uma regra geral de reprodução social. Mesmo assim, preferi mantê-lo como uma referência ao processo pelo qual um determinado grupo extrai excedente de outro, não importando, neste caso, o fato de que este excedente seja em forma de produto e que o objetivo, em geral, seja usá-lo e não acumulá-lo.

${ }^{2}$ Lefebvre (1999, pág. 15).
} 
Viu-se como o dinheiro é transformado em capital, como por meio do capital é produzida mais-valia e da mais-valia mais capital. A acumulação de capital, porém, pressupõe a mais-valia, a mais-valia a produção capitalista, e esta, por sua vez, a existência de massas relativamente grandes de capital e força de trabalho nas mãos dos produtores de mercadorias. Todo esse movimento parece, portanto, girar num círculo vicioso, do qual só podemos sair supondo uma acumulação "primitiva" (previous accumulation em A. Smith) anterior à acumulação capitalista, uma acumulação que não é o resultado do modo de produção capitalista, mas sim seu ponto de partida ${ }^{3}$.

A acumulação não capitalista é aí denominada de acumulação primitiva o que pondo-se de lado as polêmicas das traduções ${ }^{4}$ - parece deixar bastante claro o seu sentido. Considerando-se que este trecho é apenas o início do capítulo especificamente voltado à discussão da acumulação primitiva e que na seqüência Marx trata de diversos eventos históricos ocorridos entre os séculos XVI e XVII que colaboraram com a formação do capitalismo, o adjetivo "primitiva", parece claramente qualificar esta forma de acumulação como própria de um momento datado na história (ou na pré-história para ser mais preciso) do capitalismo. Neste sentido estrito a relação entre estas formas não capitalistas de acumulação e a acumulação expandida seria, simplesmente, que as primeiras seriam pressupostos da segunda.

Mas não é porque no texto de Marx esses pressupostos são historicamente datados que temos que considerá-los sob este ponto de vista limitado ${ }^{5}$. Um pressuposto não tem de ser, necessariamente, algo anterior. Pelo menos não no sentido de um anterior que já ocorreu e, desta forma, não precisa mais voltar a ocorrer. Isto é, um anterior datado. Ele só precisa ser algo historicamente datado nos termos de uma visão linear de história. Neste caso entende-se que o passado e o futuro estão ligados por um devir cujo sentido é inexorável. Em relação ao capital seria entender que realizada a acumulação primitiva, a

\footnotetext{
${ }^{3}$ Marx, 1988, vol. 2, p. 251.

${ }^{4}$ A tradução na qual esta acumulação aparece como primitiva é a da edição brasileira utilizada em todas as notas sobre O Capital no presente trabalho. No entanto, em uma edição portuguesa (MARX, Karl. "Capital: Capítulo XXIV, A chamada acumulação original”. In MARX, Karl \& ENGELS, Friedrich. Obras Escolhidas, Volume II. Lisboa: Edições Avante, 1983) esta acumulação aparece como original e numa outra mexicana (Cidade do México: Fondo de Cultura Económica, 1966) como originária.

${ }^{5}$ Como destaca Harvey a intenção de Marx ao pressupor que os métodos não capitalistas poderiam deixar de existir, "consiste em mostrar que a liberalização do mercado - o credo dos liberais e neoliberais - não produz uma situação harmoniosa em que a condição de todos é melhor. Produz, em vez disso, níveis ainda mais elevados de desigualdade social.” E “a desvantagem desses pressupostos é que relegam a acumulação baseada na atividade predatória e fraudulenta e na violência a uma 'etapa original' tida como não mais relevante.” (2004, pág. 120).
} 
acumulação que deu origem ao capitalismo separando os produtores dos meios de produção, o capital estaria estabelecido enquanto regra de reprodução e, desta forma, se geraria uma acumulação expandida contínua. Ou seja, seria considerar que - nas palavras de Rosdolsky - "uma vez existindo o capital, e a partir da própria produção capitalista, essa separação [entre os produtores e os meios de produção] se conserva e se reproduz em escala cada vez maior",

Manter-se nos limites desta forma de entender o devir histórico seria, como chama nossa atenção Holloway (2003), fetichizar o próprio fetiche, isto é, considerar que a alienação própria à acumulação capitalista está dada desde o momento da origem do capitalismo e que desde então há uma reprodução automática da lógica do capital. E pior, significa não compreender a abertura presente na análise que o próprio Marx realiza sobre a lógica do capital. Como demonstra Harvey - e de certa forma Grespan (1998) - se a opção marxiana é por manter o pressuposto de que a acumulação primitiva é algo datado é para com isso demonstrar que, mesmo assim, a acumulação expandida "produz sérias e crescentes instabilidades que culminam em crises crônicas de sobreacumulação"7, crises que, constantemente, tendem a pôr em xeque o capital enquanto regra de reprodução social. Nestes termos, a reprodução do capital não se daria automaticamente, exigindo a constante presença de outras formas, não capitalistas, de acumulação. Estas últimas seriam, portanto, pressupostos da reprodução capitalista não apenas no sentido de instituir historicamente suas condições, mas também no sentido de reinstituí-las, de re-produzí-las. É preciso, então, definir em que sentido se dá esta reprodução.

Um dos aspectos apontados por muitos autores na tradição marxista como característico da reprodução contraditória do capital é a sua tendência expansiva. Rosa Luxemburgo, por exemplo, adotada esta perspectiva ao tratar o problema da demanda no capitalismo. Para esta autora, a necessidade capitalista da acumulação expandida exigiria uma constante expansão sobre os mercados externos. Mercados externos, é importante notar, não seriam, necessariamente, mercados localizados em outros países, mas sim setores não capitalistas sendo incorporados pelo capitalismo. São uma referência às economias naturais - estas sim representadas por sociedades não capitalistas - e ao Estado. Como as economias naturais são limitadas e o Estado não pode absorver toda a riqueza socialmente produzida a fim de atender à crescente oferta da produção, a expansão sobre

\footnotetext{
${ }^{6}$ Rosdolsky, 2001, p. 234

${ }^{7}$ Harvey, 2004, p. 120.
} 
os mercados externos seria limitada e, com ela, o próprio capitalismo. É como se a expansão do capitalismo fosse incorporando o mundo não capitalista até se implodir.

Esta concepção de Luxemburgo se baseia numa interpretação problemática dos esquemas de reprodução de Marx. Mesmo assim, não deixa de ser interessante a idéia fundamental acerca da necessidade do capitalismo de incorporar o mundo não capitalista como condição para se reproduzir. De qualquer maneira, não é exclusiva da concepção de Luxemburgo esta necessidade imanente ao capital em se expandir. Mas o que nos interessa agora é a perspectiva, aí presente, de manutenção de formas não capitalistas de acumulação como pressupostos da reprodução do capital. No caso desta necessária expansão do capital sobre setores não capitalistas, qual seria o papel das formas não capitalistas de acumulação, ou seja, em que sentido elas seriam pressupostos do capital? Provavelmente em vários.

Um dos sentidos mais importantes a meu ver é o de que caberia a estas formas não capitalistas promoverem a incorporação de setores não capitalistas ao capitalismo, atendendo assim à exigência de constate expansão do capital. Esta incorporação se daria conforme aquilo que era externo ao capitalismo fosse se tornando interno. É um pouco problemática a imagem do capitalismo crescendo e engolindo os setores não capitalistas, posto que fica a impressão de uma passividade muito grande do mundo não capitalista diante de uma potência imanente ao capitalismo. Por isso, me parece mais interessante utilizar a imagem inversa. Para começar, os setores não capitalistas, passariam a ter a lógica capitalista como regra de sua própria reprodução. Ou seja, sua reprodução passaria a ser mediada pela lógica do capital. Com isso, para se reproduzirem passariam a externalizar seus elementos não capitalistas, eliminando os obstáculos à acumulação da riqueza abstrata. Ou, o que dá no mesmo, as formas não capitalistas estariam internalizando a lógica de reprodução do capital.

Mas há neste processo um ponto fundamental a ser esclarecido. Se partimos da idéia de que a reprodução ampliada do capital não pode ocorrer de forma automática não faria sentido imaginar que a incorporação de setores não capitalistas ao capitalismo poderia se dar sem uma ruptura, isto é, sem um mecanismo não capitalista que os levasse a ter a lógica da acumulação capitalista como sua regra de reprodução, como sua mediação. Se assim o fizéssemos estaríamos recaindo no mesmo problema que, como vimos no capítulo 1, Wood identifica em muitos estudiosos da transição entre o feudalismo e o capitalismo, qual seja, deixar de discutir a própria origem da acumulação capitalista. Pode-se rejeitar 
esta observação argumentando que não estamos falando aqui do início do capitalismo mas sim de sua expansão, mas isso não muda as coisas.

Da mesma maneira que muitos dos estudiosos da transição viram na lógica da busca do lucro um comportamento quase universal - que só não teria se generalizado anteriormente pela presença de obstáculos culturais, sociais ou religiosos - ao supormos que em contato com o capitalismo os setores não capitalistas acabam sendo automaticamente incorporados estaríamos reafirmando esta visão. Para evitar este desvio é preciso entender que há nesta incorporação uma forma não capitalista de acumulação, a qual teria a função, neste caso, de impor a reprodução capitalista como regra de reprodução dos setores não capitalistas, a partir do que haveria, aí sim, uma necessidade por parte destes de internalizar a lógica capitalista de reprodução. Neste caso, considero que mesmo ocorrendo em qualquer período do capitalismo a acumulação não capitalista tem em relação à acumulação propriamente capitalista a mesma função apontada por Marx para a acumulação primitiva, qual seja, ser o pressuposto da acumulação capitalista - ou, para ficar mais claro - um pressuposto da expansão do capital em direção a setores não capitalistas. Esta - a acumulação primitiva - é uma das formas de acumulação não capitalista que precisamos diferenciar das outras às quais vou me referir adiante. Antes, porém, resta saber como exatamente a acumulação primitiva cumpre o seu papel.

Neste questionamento, me parece que o próprio termo "acumulação" leva a entendimentos muitas vezes nebulosos. Por exemplo, muitos associam a acumulação primitiva a processos de transferência de riqueza entre produtores e apropriadores por meio de maneiras violentas de dominação como seria, por exemplo, a escravidão e a colonização. É certo que no próprio texto de Marx muitos exemplos históricos são trabalhados neste sentido. A acumulação primitiva aparece, em parte, como uma pilhagem por meio da qual o capital necessário para se iniciar a produção capitalista é formado. Mas se analisarmos a questão mais de perto podemos perceber que há aí uma concepção limitada do próprio capital. Rosdolsky observa que:

Nada mais estúpido que conceber essa formação primitiva do capital como se este tivesse acumulado e criado as condições objetivas da produção - meios de subsistência, matérias-primas, instrumentos - e as houvesse entregado aos trabalhadores despojados delas. [...] Todos esses elementos existiam; sua separação é um processo histórico, um processo de dissolução, e é esse processo que permite ao dinheiro 
transformar-se em capital. Nesse processo o próprio dinheiro só é ativo quando intervém como meio de separação extremamente enérgico e ajuda a criar trabalhadores despossuídos, objetivamente livres; não cria para eles as condições objetivas de sua existência mas ajuda a acelerar sua separação dessas condições ${ }^{8}$.

É certo que, a priori, esta observação se refere à ingenuidade de se identificar a acumulação primitiva com algo como a formação do "capital inicial". Mas afinal, se por um lado este raciocínio é limitado por imaginar que o capitalista conseguiu acumular o "capital inicial" por meio de seu próprio esforço ou algo que o valha, por outro, é também limitador o raciocínio que imagina que a acumulação primitiva é apenas uma transferência de uma riqueza que já existia nas mãos dos trabalhadores para as dos capitalistas por meio da violência. Se fosse apenas isso em que ela se diferenciaria de todas as formas anteriores de pilhagem, de extração do excedente com base na violência? A questão, portanto, é a seguinte, por que o domínio dos romanos sobre os povos do Império, por exemplo, não era um processo de acumulação primitiva enquanto a colonização e a escravidão modernas, assim como o Imperialismo do século XIX, o são?

Aproveitando a afirmação de Marx de que a acumulação primitiva é um pressuposto da acumulação expandida basta notar que as formas pré-capitalistas de acumulação não são pressupostos da acumulação expandida. Ou seja, estas formas se esgotam em si mesmas não levando à efetivação da acumulação propriamente capitalista. Por sua vez, a acumulação primitiva é o pressuposto da acumulação capitalista, sendo dela fundadora ou re-fundadora, produtora ou re-produtora.

Ao se considerar esta especificidade da acumulação primitiva pode começar a ficar claro o problema que o próprio termo acumulação pode trazer ao seu entendimento. Sua utilização pode nos levar à idéia de que o que importa identificar é um acúmulo de riqueza. Como disse, uma riqueza que parece já existir, sendo apenas transferida de um grupo para outro. Mas o problema central aí é que nos termos da acumulação capitalista nada é riqueza a priori. Como demonstrei no capítulo 3 a regra de reprodução social característica da sociedade capitalista é a abstração da riqueza. Neste caso, de nada adiantaria tomar as terras de uma determinada população se esta pilhagem se limitasse à transferência das terras para as mãos dos espoliadores. Isso era o mesmo que tribos guerreiras faziam na antiguidade européia. Mesmo que haja uma continuidade de métodos violentos de extração

\footnotetext{
${ }^{8}$ Rosdolsky, 2001, p. 233
} 
do excedente no capitalismo, esta continuidade não é absoluta. Ao ocorrerem num contexto novo estas formas não capitalistas - caso possam ser identificadas como acumulação primitiva - ganham um novo sentido, que é o de se integrar à reprodução da riqueza abstrata.

Assim sendo, mesmo existindo este aspecto de transferência de riqueza por meios violentos na acumulação não capitalista, o problema é que tal transferência, em si, não dá conta de nos auxiliar no entendimento das relações entre estas formas de acumulação e a acumulação propriamente capitalista. Inclusive, ao que me parece, dar ênfase isoladamente a este aspecto pode significar um risco de retrocesso analítico. Veja-se o caso dos últimos textos de David Harvey, nos quais este autor - que continuo considerando muito importante para o presente trabalho - se propõe analisar o que chama de novo imperialismo. Apesar de trabalhar com alguns aspectos interessantes sobre a relação da dinâmica capitalista com a produção do espaço - mas que não são novidade em sua obra e de tomar cuidado para separar o joio do trigo (diferenciando o neoliberalismo do neoconservadorismo, este último identificado diretamente com os processos de acumulação baseada na pilhagem) Harvey acaba caindo numa posição teórica ambígua. Para dizer que há algo novo no panorama da economia mundial a partir de meados da década de 1970 - e principalmente no pós 11 de setembro - o autor se preocupa em identificar o aspecto de transferência de riqueza entre grupos por meios "predatórios e fraudulentos" presente na acumulação primitiva. Ele só não usa esta expressão por considerar "estranho qualificar de 'primitivo' ou 'original' um processo em andamento", substituindo-a, no original em inglês, pela expressão accumulation by dispossession.

Em seu livro Novo Imperialismo (com tradução de Adail Sobral e Maria Stela Gonçalves) o termo inglês dispossession é traduzido como espoliação o que acentua a imagem de uma acumulação por meio "da atividade predatória e fraudulenta” (2004, pág, 120). É preciso observar que numa reprodução de parte do mesmo livro feita na Revista Margem Esquerda $\mathrm{n}^{\circ} 5$ (com tradução de Danilo Cerqueira César) o mesmo termo é traduzido como despossessão o que, a meu ver, dá um ganho de complexidade uma vez que pode se entender despossessão como eliminação da posse. No texto de Harvey os dois sentidos estão presentes sem que haja uma diferenciação adequada entre eles, não sendo a ênfase no aspecto de espoliação um problema apenas de tradução. O problema de tudo isso, a meu ver, é que esta opção por enfatizar indistintamente o aspecto fraudulento e

\footnotetext{
${ }^{9}$ Harvey, 2005, pág. 121.
} 
predatório da acumulação não capitalista, sendo aparentemente uma crítica mais incisiva ao capitalismo é, na verdade, frágil em termos de crítica, uma vez que dá a entender que a acumulação expandida não estaria baseada em fraudes e em alguma forma de ação predatória. A impressão que se tem com isso é que o capitalismo só seria um problema sério durante suas crises, nas quais teriam de ser utilizados métodos violentos para extração de excedente.

No entanto, como afirmei, no próprio texto de Harvey não está presente apenas este aspecto da acumulação não capitalista. Se nos fixarmos no termo despossessão podemos, aí sim, ter um ganho teórico para entender as relações entre a acumulação primitiva e a acumulação capitalista. Ao nos levar à idéia de eliminação da posse, o termo despossessão pode ter o sentido - e efetivamente o tem no referido texto - não de tomada à força da riqueza de alguém, mas sim de substituição da condição de posse na qual certas riquezas estavam inseridas, pela condição de propriedade privada. Neste caso, o termo acumulação não se limita à transferência de riqueza entre grupos, expandindo-se para o campo semântico da imposição de certos condicionamentos como regras de reprodução nas relações de poder entre tais grupos. É a esta dimensão da acumulação não capitalista, que se refere Rosdolsky no final do último trecho citado. Esta é, justamente, a dimensão da separação promovida por um processo de acumulação primitiva entre os trabalhadores e as condições de produção de riqueza. Esta separação faz muito mais do que transferir aos capitalistas a riqueza que já existia, ela transfere a eles o controle sobre o processo de trabalho, dando-lhes o poder de definir as finalidades de tal processo, a qual, como se sabe, passa nesse momento a ser a valorização do valor, isto é, a expansão da riqueza abstrata. A acumulação primitiva ganha, portanto, um sentido de separação (que parece indicar de forma mais precisa o que significa este processo se comparado ao termo acumulação), como é possível verificar no seguinte trecho, extraído do capítulo de O Capital no qual Marx trata da "assim chamada acumulação primitiva";

Dinheiro e mercadoria, desde o princípio, são tão pouco capital quanto os meios de produção e de subsistência. Eles requerem sua transformação em capital. [...] O processo que cria a relação-capital não pode ser outra coisa que o processo de separação do trabalhador da propriedade das condições de seu trabalho, um processo que transforma, por um lado, os meios sociais de subsistência e de produção 
em capital, por outro, os produtores diretos em trabalhadores assalariados $^{10}$.

Numa primeira leitura, podemos identificar esta separação simplesmente como uma espoliação das condições de trabalho do trabalhador. E é realmente algo que acontece aí. Mas é preciso ir além da identificação deste processo como uma espoliação para compreendê-lo como fundação, como posição do capital. Neste sentido é importante notar que a tal separação entre trabalhadores e meios de produção cria a relação-capital ao transformar os meios de produção em capital e os produtores em assalariados. Do ponto de vista do trabalhador isso significa que ele passará a trabalhar segundo os requisitos do trabalho que produz riqueza abstrata. Mas é importante também entender que do ponto de vista do dono destes meios de produção eles terão de ser utilizados como capital, isto é, terão de ser usados de forma a consumir a força de trabalho segundo os requisitos da reprodução da riqueza abstrata. Assim sendo, com esta separação, produz-se uma alienação que significa que tanto o capitalista como o trabalhador passam a ter sua reprodução mediada pelas condições do mercado propriamente capitalista.

Os cercamentos - mais famoso exemplo de acumulação primitiva - nada mais são do que estes processos de separação entre os produtores e as condições da produção. Quando se pensa num processo de cercamento é um equívoco imaginar que um senhor de terras toma a terra dos camponeses e os expulsa dali. Que vantagem um tal senhor teria? Ficaria com toda a terra para ele, mas quem a utilizaria para produzir? Propriedade não é isso. Como nos chama atenção Daniel Bensaïd (2004), os movimentos sociais do século XIX (comunistas ou anarquistas) já tinham percebido que "propriedade é poder". Ou mais explicitamente, para Holloway, poder sobre o trabalho dos outros. Mas note-se algo fundamental, propriedade é um poder mediado pela reprodução do capital. No caso das terras "cercadas", por um lado seu proprietário passa a poder condicionar seu uso à valorização do valor, por outro, ele tem de fazê-lo sob pena de perder as terras caso não o consiga. A conseqüente expulsão de camponeses numa situação dessa não se deve à acumulação primitiva em si, mas sim aos seus efeitos. Afinal se o uso da terra ganha uma nova dimensão (criar ovelhas, por exemplo, ao invés de plantar batatas) é este novo uso, que atende às exigências da acumulação expandida, que leva à expulsão. O mesmo ocorre no caso dos "novos cercamentos", aos quais se refere James Boyle, que segundo Bensaïd,

\footnotetext{
${ }^{10}$ Marx, 1988, vol. II, pág. 252.
} 
estabeleceu um paralelismo entre o estabelecimento dos cercamentos nas terras e as expropriações que acompanharam a acumulação inicial de capital (evocadas por Marx em um capítulo magnífico de O Capital) $e$ o estabelecimento de novos cercamentos aos bens intelectuais. Do mesmo modo como em seu tempo a privatização da terra foi defendida em nome do aumento da produtividade agrícola para poder fazer frente à escassez e à fome (ainda que fosse ao preço de uma nova miséria urbana) atualmente estaríamos assistindo a uma nova onda de "cercamentos", que partidários justificam em função do progresso inovador, ou se se referem aos organismos geneticamente modificados, da crise de abastecimento no mundo ${ }^{11}$.

A acumulação primitiva - pretérita ou atual - está, enfim, diretamente ligada à separação entre a produção e a realização da riqueza. O que esta separação permite é que um grupo - o grupo dos proprietários - comande o uso das condições da produção. $\mathrm{O}$ aspecto de transferência de riqueza aí presente não se refere à transferência destas condições de produção como riqueza em si, mas sim à criação da possibilidade de transferência do excedente produzido por meio de um determinado uso de tais condições, isto é, por meio de seu uso propriamente capitalista. Talvez, com isso, se tenha a impressão de que a diferença entre acumulação capitalista e acumulação primitiva se dissolve, o que não é verdade. Para entender melhor esta diferença há que se interpretar o seguinte trecho de De Angelis;

Existem três pontos centrais que eu acredito serem as chaves para o entendimento da abordagem que Marx faz para chegar à acumulação primitiva. O primeiro é que a separação entre produtores e meios de produção é uma característica comum não só da acumulação como da acumulação primitiva. O segundo é que esta separação é uma categoria central (se não a categorial central) da crítica de Marx à economia política. $O$ terceiro é que a diferença entre acumulação e acumulação primitiva, vem da diferença das condições e formas pelas quais esta separação é implementada ${ }^{12}$.

A partir disso é possível definir que a acumulação capitalista tem como pressuposto (constante) a separação entre a produção e a realização da riqueza. Esta separação nada

\footnotetext{
${ }^{11}$ Bensaïd, 2004, pág. 29.

${ }^{12}$ De Angelis, 2001, pág. 6
} 
mais é do que a efetivação da alienação, a fetichização, a posição do valor. A própria acumulação expandida recria, de certa forma, esta separação. No entanto, em situações nas quais tal separação é promovida por outras lógicas que não a da própria reprodução do capital, têm-se uma forma de acumulação primitiva.

Mas como foi dito no início do capítulo, existem outras formas de acumulação não capitalista que continuam a existir no interior do capitalismo e que estabelecem diferentes relações com a reprodução do capital. A acumulação primitiva da qual tratei nas últimas páginas é uma delas e sua relação com o capitalismo se dá no sentido dela ser o pressuposto da acumulação propriamente capitalista, isto é, aquilo que prepara o terreno, digamos, para que o capitalismo possa chegar - a um lugar a um âmbito qualquer da estrutura social no qual ele ainda não estava presente. A seguir tratarei de uma forma de acumulação não capitalista que se aproxima bastante da acumulação primitiva e, inclusive é assim denominada por muitos autores. Não entrarei no mérito, muito problemático, de discutir a correção ou não dos usos de acordo que esta ou aquela interpretação dos textos de Marx ou de qualquer outro clássico, até porque acabaríamos numa discussão escolástica sem maior importância para o presente trabalho. $\mathrm{O}$ que pretendo apenas é discernir formas de acumulação não capitalistas que segundo os pressupostos aqui adotados têm sentidos diferentes na reprodução do capital e, desta forma, precisam ser diferentemente nomeadas.

A forma de acumulação não capitalista a qual acabei de me referir acima se caracteriza pelo seguinte. Ao invés de ser um pressuposto à acumulação capitalista no sentido de preparar o terreno para que esta última ocorra, é uma forma de acumulação que por métodos não capitalistas complementa a reprodução capitalista sem, necessariamente, ser incorporada por ela. Ou seja, é uma forma de acumulação que não tem a função de incorporar um setor não capitalista ao capitalismo, mas, isto sim, de mantê-lo como não capitalista. Muitas das referências que Harvey faz em seus textos sobre o novo imperialismo parecem ter este sentido. $\mathrm{O}$ sentido de o capitalismo precisar manter, ou mesmo produzir, constantemente, um âmbito não capitalista de acumulação como seu complemento. É isso também o que dá a entender a diferenciação feita por André Gunder Frank, que segundo Moraes (2000)

Argumenta que a acumulação é primitiva por se realizar em meio a relações pré-capitalistas, distinguindo-a da acumulação originária, na 
qual o avanço do capitalismo criaria relações não-capitalistas, como o escravismo moderno, por exemplo ${ }^{13}$.

Frank dá ênfase ao contexto temporal no qual ocorre a acumulação não capitalista, o que resulta em nomear aquelas que se dão antes do capitalismo como primitivas e as que se dão dentro do capitalismo como originárias. A meu ver esta diferenciação temporal faz pouco sentido, sendo mais interessante fazermos uma diferenciação com base na maneira como cada forma de acumulação se relaciona com a reprodução capitalista. Mas este aspecto não parece estar fora da concepção de Frank. A acumulação originária à qual ele se refere não tem o mesmo caráter da acumulação primitiva que permanece nos estágios avançados do capitalismo como eu defini acima. Ao contrário, é uma forma de acumulação que se refere à extração do excedente de forma não capitalista, por exemplo a escravidão moderna ou os diversos tipos de mão de obra não proletarizada que podemos encontrar em diversos lugares do mundo até hoje. Neste caso, portanto, o termo acumulação já pode ser entendido em seu sentido mais corrente, que é o de acúmulo de riqueza, extração de excedente. Acumulação originária, segundo o que considerarei de aqui em diante, seria, portanto, o uso de elementos não capitalistas para garantir os lucros num contexto capitalista. Enquanto a acumulação primitiva é uma separação que põe o capital, a acumulação originária seria uma separação que mantém um setor relativamente isolado da lógica da riqueza abstrata. Neste sentido talvez seja interessante considerar a idéia da espoliação utilizada por Harvey.

Para que a acumulação originária ganhe um sentido mais importante no entendimento do capitalismo atual ela não pode ser entendida de forma absoluta. Afinal o que seria, atualmente, uma forma absolutamente originária de acumulação? Escravidão? Harvey até se refere à permanência da escravidão "particularmente no comércio sexual"14, mas não acho que possa se considerar isso de grande importância para o entendimento da reprodução do capital em grande escala.

Penso que cabe aqui entendermos que a acumulação originária pode ser relativa no sentido de mesmo quando um setor é incorporado ao capitalismo às vezes ele não o é de forma completa, permanecendo resquícios de formas não capitalistas de dominação. Um exemplo interessante é o das diversas formas de discriminação de "minorias". Segundo a lógica do capital a força de trabalho deve ser reduzida a puro gasto e tempo do trabalhador,

\footnotetext{
${ }^{13}$ Moraes, 2000, p. 34.

${ }^{14}$ Harvey, 2005, pág. 121.
} 
independentemente de quem seja este trabalhador. Neste sentido, a proletarização deveria igualar os trabalhadores, mesmo que os igualando enquanto força de trabalho em geral. No entanto, como sabemos, em países como o Brasil trabalhadores negros ganham, em média, menos que trabalhadores brancos para exercer as mesmas funções, sendo igualmente verdadeira esta discriminação em relação às mulheres. O que temos é uma diferenciação não capitalista que obstaculariza a integração completa do trabalhador negro ou da mulher à lógica da reprodução capitalista. Mas isso não porque eles não façam parte da reprodução do capital, mas porque não o fazem de forma totalmente capitalista. Na verdade, em parte de forma capitalista, considerando a proletarização, mas não totalmente capitalista já que parte da extração de excedente que se dá sobre eles obedece a uma lógica não capitalista, que é a lógica da descriminação. O mesmo podendo ocorrer com outras "minorias", como os imigrantes ilegais. O que vemos, nestes casos é que a permanência de lógicas não capitalistas tem o seu lugar dentro do capitalismo. Aliás, permanência pode até ser uma forma limitada de se referir a elas, posto que dá a entender que são formas que já existiam antes do capitalismo. Ao contrário disso, como nos lembra Harvey;

$\mathrm{Na}$ linguagem da teoria política pós-moderna contemporânea, poderíamos dizer que o capitalismo cria, necessariamente e sempre, seu próprio outro. A idéia de que algum tipo de "exterior" é necessário à estabilização do capitalismo tem por conseguinte relevância. Mas o capitalismo pode tanto usar um exterior pré-existente (formações sociais não-capitalistas ou algum setor do capitalismo - como a educação - que ainda não tenha sido proletarizado) como produzi-lo ativamente ${ }^{15}$.

De qualquer forma, podemos dizer que o sentido geral da acumulação originária é bastante diferente do da acumulação primitiva - isso, é claro, da maneira como estou considerando ambas no presente trabalho. Isto porque no caso da acumulação primitiva as separações que originalmente faziam de um setor algo não capitalista são eliminadas e substituídas pela separação propriamente capitalista, isto é, a lógica capitalista passa a ser a mediação de sua reprodução. Ao contrário, no caso da acumulação originária, as separações que fazem de um determinado setor algo não capitalista, ou não totalmente capitalista, são forçosamente mantidas, de modo que os capitalistas individuais utilizam este setor como algo que permanece, ao menos em parte, fora de sua própria lógica do capital em geral.

\footnotetext{
${ }^{15}$ Harvey, 2004, p. 118.
} 
Mas algo em comum há entre estas duas formas de acumulação não capitalista, o fato de que ambas de uma forma ou de outra estão diretamente subordinadas às necessidades de reprodução do capital. Inclusive, mesmo quando podem ser identificadas como heranças de formas pré-capitalistas, seu sentido dentro do capitalismo é de colaborar com a reprodução do capital. É o que muitas vezes ocorre com formas de dominação sexistas, racistas ou religiosas. Porém, seria analiticamente empobrecedor - posto que no fundo estaríamos nos aproximando dos esquemas base-superestrutura - considerar que todas as formas não capitalistas de acumulação são absolutamente absorvidas pela reprodução do capital. No sentido daquela sugestão de Lefebvre segundo a qual deveríamos nos preocupar com as relações entre continuidades e descontinuidades, o que estaríamos fazendo é considerar que todas as continuidades de formas pré-capitalistas dentro do capitalismo estariam servindo agora à efetivação dos objetivos da reprodução da riqueza abstrata, deixando para trás quaisquer outras finalidades que lhes fossem próprias.

Não acho que este caminho nos permita ir muito além dos economicismos já criticados anteriormente. Por isso, além das formas não capitalistas que apontei até aqui - a acumulação primitiva e a acumulação originária - há ainda uma terceira forma considerar. Esta, mesmo existindo dentro dos limites de sua relação com a acumulação capitalista, não se resume a uma mediação para a efetivação dos fins do capital, repondo, ao invés disso, a necessidade de seus próprios fins. No caso, estou pensando especificamente numa forma de acumulação que delinearei melhor a seguir, mas que desde já vou denominando de estatista.

\section{1 - O Estado e a acumulação}

As relações entre o Estado e a acumulação são genéticas. Começando por algumas reflexões sobre o Estado em geral, particularmente em sua forma pré-capitalista ${ }^{16}$, é preciso reconhecer que nenhum Estado jamais existiu sem que houvesse um processo de acumulação envolvido. E nesse caso podemos pensar no termo acumulação simplesmente como transferência de riqueza de um grupo para outro. É imprescindível que um grupo se aproprie de menos riqueza do que produz para que outro possa se apropriar desse

\footnotetext{
${ }^{16}$ Não tenho a pretensão de me referir a Estados que realmente existiram antes do capitalismo, até porque me faltaria condição para tanto. Ao invés disso, a intenção das reflexões dos próximos parágrafos é preparar a análise, será feita logo à frente, sobre o Estado no capitalismo. Neste sentido, mesmo que estes primeiros parágrafos não apareçam como uma reflexão sobre o Estado capitalista, na verdade eles o são.
} 
excedente e tenha, com isso, a possibilidade de comandar o Estado. Nesse sentido, a gênese do Estado está diretamente ligada à produção de um excedente, isto é, à ocorrência da alguma forma de acumulação.

O excedente, por sua vez, só existe quando há uma separação entre a produção de riqueza e sua realização. Quando parte da riqueza que alguém produz não é apropriada por esse alguém significa que ela não se realizou como riqueza para ele e sim para o outro. Esta separação entre a produção e a realização da riqueza, quando promovida diretamente pelo Estado (não capitalista) se dá pelos meios que o estado tem para implementá-la e estes meios são os meios da violência. Ou, como aponta Smith,
A produção de excedente social permanente leva a sociedade humana a começar o seu longo processo de emancipação face às restrições da natureza. Por outro lado, este controle aumentado é necessariamente um controle social, e embora ele assessore a emancipação da sociedade humana como um todo em face da natureza, ele também favorece o desenvolvimento da diferenciação interna da sociedade e a escravidão de grande parte da população ${ }^{17}$.

Com isso, é possível vislumbrar dois sentidos de separação na constituição do Estado. Estando fundado na extração de excedente ele se liga diretamente à separação entre a produção e a realização da riqueza. Mas esta separação é implementada por meio do controle social de um grupo sobre outro, o que significa uma diferenciação interna da sociedade. Isto significa que a própria existência do Estado indica a existência de um grupo de expropriadores e outro de expropriados.

O grupo de expropriadores passa a depender da continuidade da produção de excedente para se reproduzir, não podendo dela abrir mão. Isto é, a extração de excedente se torna a mediação da reprodução do grupo expropriador ligado ao Estado. Mas há que se considerar que a manutenção da extração do excedente só se dá pela manutenção dos meios de separação, ou seja, dos meios de controle e que estes meios de controle - forças armadas, prisões, executores das leis, fiscais - só podem subsistir absorvendo parte do excedente suja extração eles mesmos garantem. Com isso, o que temos é que a extração do excedente e sua destinação à estrutura estatal é a mediação para a reprodução do grupo de

\footnotetext{
${ }^{17}$ Smith, 1988, pág. 77
} 
expropriadores que comanda o Estado e, igualmente, para a reprodução (expandida ou não) do poder desse mesmo Estado.

Essa dupla condição de mediação da extração do excedente em relação à estrutura estatal, não nos permite enxergá-lo como um elemento passivo. Meramente superestrutural, por exemplo. Ao contrário, a necessidade de se reproduzir por meio da manutenção das condições de extração do excedente faz do Estado um elemento ativo e essa atividade é determinada por uma cisão entre Estado e sociedade. Cisão esta que não produz uma autonomia do Estado, mas sim a dependência deste em relação ao excedente proveniente daquela. Mesmo que esta condição, novamente, pareça apontar para a passividade do Estado - o Estado como um mero produto da sociedade - o que é preciso destacar é que a necessidade de reprodução do grupo que o comanda e do poder de comando leva o Estado a passar de produto a produtor. Produtor não do excedente, mas das condições sociais que possibilitam a extração do excedente.

No Estado não-capitalista estas condições são diretamente ligadas ao uso da violência, isto é, da coerção direta. Mas a coerção não pode se dar em abstrato, desterritorializada. Ao contrário, a coerção é sempre sobre uma determinada área, sobre um determinado território. Portanto, o Estado é necessariamente territorial. O que é claro, não impede que um Estado exerça poder fora de seu próprio território. Mas, de qualquer forma, pensando num Estado pré-capitalista poderíamos dizer que há uma tendência à coincidência de três elementos: Estado, sociedade e território. O Estado é a estrutura de dominação que exerce poder sobre um determinado território no qual há uma sociedade que gera excedente para a reprodução da própria estrutura estatal.

Mas se nestes primeiros parágrafos do presente item me referi ao Estado de forma tão genérica foi, por um lado, para gerar alguns parâmetros comparativos, isto é, entender o que é o Estado capitalista a partir de elementos do Estado não capitalista. Por outro lado, no entanto, isso não significa que algumas características do Estado, acima apontadas, tenham desaparecido totalmente no Estado capitalista. Neste sentido, a intenção destes primeiros parágrafos foi também iniciar um delineamento do que podemos chamar de o elemento estatista. Algo que é próprio do Estado não capitalista, mas que se mantém no capitalismo. Continuidade que só pode ser entendida no contexto das descontinuidades e, por isso, é preciso se perguntar sobre a especificidade do Estado capitalista. Neste sentido, 
Questionar a forma do Estado é levar a pergunta à sua especificidade histórica: a existência do Estado como algo separado da sociedade é algo peculiar à sociedade capitalista, como é a existência do "econômico" como algo distinto das relações de classe abertamente coercitivas. Então a pergunta não é: como a superestrutura econômica determina a superestrutura política? Na verdade, a pergunta é: qual é a peculiaridade das relações sociais do capitalismo que faz surgir a rigidificação (ou a particularização) das relações sociais na forma do Estado? O corolário disso é a seguinte pergunta: o que faz surgir a constituição do econômico e do político como momentos distintos das próprias relações sociais ${ }^{18}$ ?

Se no Estado pré-capitalista já podíamos reconhecer uma separação entre Estado e sociedade, no capitalismo a novidade é que o Estado existe numa condição em que o político e o econômico foram separados. Isso não significa o mesmo que aquela diferença entre Estado e sociedade. Naquela, o Estado era o conjunto do grupo expropriador e os elementos da estrutura de reprodução do poder estatal, enquanto a sociedade era o conjunto dos produtores, dos geradores do excedente. Por seu turno, a separação entre o político e o econômico significa que a extração do excedente - que caracteriza a base econômica passa a se dar por meios puramente econômicos e não mais políticos como se dava anteriormente. Ou seja,

Sob o capitalismo a relação entre classes se baseia em uma forma de exploração que não existe abertamente, mas através da "livre" compra e venda da força de trabalho como uma mercadoria no mercado. Essa forma de relação de classes pressupõe uma separação entre o processo imediato de exploração, que se baseia na "liberdade" do trabalho e no processo de manutenção da ordem em uma sociedade exploradora, que implica a necessidade de coerção ${ }^{19}$.

A extração do excedente sai agora do controle direto do Estado, passando a ser efetivada pelos capitalistas de forma puramente econômica. Nasce com isso o que podemos chamar de âmbito do econômico, isto é, a economia como uma esfera social facilmente distinguível das outras. Esta separação do econômico em relação ao político foi

\footnotetext{
${ }^{18}$ Holloway, 2003, pág. 142

${ }^{19}$ Holloway, 2003, pág. 142
} 
muito mal interpretada por pensadores de correntes teóricas, às vezes, bastante distintas, como aponta Wood no seguinte trecho;

A economia política burguesa, de acordo com Marx, universaliza as relações de produção quando analisa a produção abstraindo suas determinações sociais específicas - relações sociais, modos de propriedade e de dominação, formas políticas ou jurídicas específicas. Isso não quer dizer que a "base" econômica se reflita em certas instituições "superestruturais" e por elas seja mantida, mas que a base produtiva em si existe sob o aspecto de formas políticas, sociais e jurídicas - em particular, formas de propriedade e dominação ${ }^{20}$.

Pelo que está posto neste trecho podemos entender que tanto os liberais como os marxistas-estruturalistas entenderam a separação do econômico em relação ao político como uma autonomização do econômico e mesmo como a determinação da economia sobre as outras esferas sociais. $\mathrm{O}$ que fica mal compreendido em ambas as visões é que a separação do econômico significa apenas que um processo social - muito importante, é claro - passa a se dar primordialmente no campo do econômico. Este processo é simplesmente a extração do excedente. É apenas esta extração que passa a se limitar ao econômico e não todo o resto da sociedade. É claro que isso tem consequiências muito importantes para a reprodução social, mas como veremos a seguir estas conseqüências não podem ser entendidas pelos esquemas base-superestrutura.

Principalmente não podem porque a extração puramente econômica do excedente só pode se dar tendo como contrapartida a regulação política das condições nas quais esta extração vai ocorrer. Para poder descrever melhor esta situação é interessante passarmos a considerar a partir daqui uma diferenciação entre a acumulação econômica (extração puramente econômica do excedente) e a acumulação política (produção das condições nas quais se dá a acumulação econômica). Esta última pode ser diretamente identificada com as formas não capitalistas de acumulação às quais me referi no início deste capítulo. Destaquei três formas de acumulação não capitalista, ou seja, a acumulação primitiva, a acumulação originária e a acumulação estatista. Destas três formas tratarei a seguir, mas antes é preciso identificar ainda o sentido geral destas formas não capitalistas em suas relações com o Estado.

\footnotetext{
${ }^{20}$ Wood, 2003, p. 29.
} 
A extração puramente econômica do excedente pode ser entendida como a extração do excedente por meio do assalariamento, isto é, a extração da mais-valia. Este processo, no entanto, não é autônomo. Não o é, para começar, porque a mais-valia só pode ser produzida em um processo produtivo organizado em torno da propriedade privada dos meios de produção e como se sabe apenas o Estado pode regulamentar a propriedade e fazer com que esta regulamentação se cumpra. Desta forma, se a "propriedade é poder", ela é um poder que não tem autonomia, posto que depende do poder do Estado para garantir sua reprodução. Mas para além da propriedade privada dos meios de produção, como vimos, a produção de mais-valia só pode se dar quando as condições do mercado capitalista estão postas.

As condições do mercado capitalista são as condições da abstração das relações sociais, isto é, as relações sociais anteriormente específicas e diversas sendo abstraídas de acordo com a forma equivalência tão preciosa para a efetivação do mundo da mercadoria. Neste sentido, para Lefebvre;

A teoria geral das formas foi exposta em diversas tomadas (por exemplo a propósito da forma espacial e do espaço social) mas de uma maneira limitada, sob um certo aspecto. Trata-se agora de generalizá-la mostrando como algumas grandes formas, tal como a forma jurídica (o direito, a lei), a forma moral (o imperativo), a forma lógica (coerência coesão), a forma política enfim tornam-se produtoras (de relações sociais) e se realizam na existência social (o concreto), tudo se identificando no e pelo Estado ${ }^{21}$.

Para a efetivação da forma mercadoria, portanto, é fundamental a efetivação de uma série de formas abstratas que, juntas, compõem a produção, pelo Estado, das condições gerais segundo as quais se dará a extração puramente econômica do excedente. Isso demonstra a dependência da acumulação econômica em relação à política. Por outro lado, no entanto, a acumulação política também não tem autonomia, posto que toda a estrutura Estatal para se reproduzir depende da extração do excedente que agora se dá apenas em termos econômicos, fugindo ao controle do Estado.

Neste sentido, é muito importante lembrar que o excedente no capitalismo não é um excedente em produto mas sim em valor. Como vimos, a valorização do valor é mediada

\footnotetext{
${ }^{21}$ Lefebvre, Del 'Etat.
} 
pelas condições do mercado propriamente capitalista. Sintetizando tais condições como a necessidade imposta - pela concorrência no mercado - aos capitalistas de aumentar constantemente a produtividade para efetivamente realizarem a riqueza (abstrata) produzida sob seu comando, podemos entender que a geração das condições para que isso ocorra passa a ser uma necessidade também do Estado. Na reprodução capitalista Estado e capital estão unidos em suas necessidades. Sobre esta união é interessante compararmos duas visões sobre o capitalismo que apesar de serem bastante díspares atingem pontos complementares.

Ellen Wood, como vimos, entende o capitalismo como o domínio das relações de mercado como imposição e não como oportunidade, ao contrário dos liberais. A partir do momento que os produtores ficam expostos à concorrência no mercado têm de aumentar constantemente a produtividade sob pena de perderem suas próprias condições de reprodução caso não o façam. O capital, poderia ser entendido na obra de Wood como a mediação do mercado propriamente capitalista para a reprodução dos agentes econômicos. Esta mediação, no entanto, não vem do nada, ao contrário ela é produzida politicamente. É o que fica claro no seguinte trecho;

\begin{abstract}
No volume I de O Capital, Marx desenvolve a evolução da forma mercadoria passando pela mais-valia até "o segredo da acumulação primitiva", revelando por fim que o "ponto de partida" da produção capitalista "não é outra coisa senão o processo histórico de isolar os produtores dos meios de produção" [citação de O Capital de Marx], um processo de luta de classes e de intervenção coercitiva do Estado em favor da classe expropriadora. A própria estrutura do argumento sugere que, para Marx, o segredo último da produção capitalista é político ${ }^{22}$.
\end{abstract}

Giovanni Arrighi, seguindo Braudel, entende a reprodução social dividida em três patamares. Um patamar inferior identificado como vida material relativo às atividades cotidianas dos seres humanos para reproduzirem suas condições de vida. Atividades estas que não são incorporadas ao universo das trocas, pelo menos não no período analisado por Braudel (séculos XV a XVIII). O patamar intermediário seria composto pelo mundo das trocas materiais, do comércio, ms não de um comércio ligado à acumulação em larga escala e sim à reprodução material dos agentes aí envolvidos. Por isso, Braudel se prende mais na idéia de troca e vê nesse patamar grandes possibilidades para a diversificação e

\footnotetext{
${ }^{22}$ Wood, 2003, pág. 28
} 
desenvolvimento da humanidade do homem. Por sua vez, o patamar superior é denominado como capitalismo. No trecho de Arrighi a seguir é possível ter uma indicação do que caracteriza este patamar.

A questão que concerne diretamente a nossa pesquisa não é quando e como uma economia mundial de mercado ergueu-se acima das estruturas primordiais da vida cotidiana, mas quando e como o capitalismo ergueu-se acima das estruturas da economia mundial de mercado preexistente e, com o decorrer do tempo, adquiriu seu poder de moldar de maneira nova os mercados e as vidas do mundo inteiro ${ }^{23}$.

A economia de mercado, para Arrighi, já existia antes do capitalismo, não sendo, portanto, sua característica fundamental. Para este autor o capitalismo se forma quando se põe sobre a economia mundial de mercado - que são para ele as tradicionais redes de comércio - gerando assim relações capitalistas de mercado. O processo pelo qual isto se dá pode ser identificado na união entre Estado e capital, como fica claro a seguir.

\begin{abstract}
Em parte alguma, com exceção da Europa, os componentes do capitalismo se fundiram na poderosa mescla que impeliu as nações européias à conquista territorial do mundo e à formação de uma economia mundial capitalista poderosíssima e verdadeiramente global, Por essa perspectiva, a transição realmente importante, que precisa ser elucidada, não é a do feudalismo para o capitalismo, mas a do poder capitalista disperso para um poder concentrado. E o aspecto mais importante dessa transição é a fusão singular do Estado com o capital, que em parte alguma se realizou de maneira mais favorável ao capitalismo do que na Europa ${ }^{24}$.
\end{abstract}

Tanto para Arrighi como para Wood o capitalismo é caracterizado pela efetivação de relações de mercado especificamente capitalistas. $O$ problema é que este especificamente capitalista não é exatamente o mesmo para ambos. Para Arrighi parece existir uma imposição - pela concentração do poder capitalista com a união Estado-capital - comportamento que já era próprio de grupos de comerciantes há muito tempo, isto é, o costume de acumular riqueza. Já para Wood o mercado capitalista se caracteriza pela alienação generalizada própria das relações de mercado funcionando como coação. Essa

\footnotetext{
${ }^{23}$ Arrighi, 1996, pág. 11

${ }^{24}$ Arrighi, 1996, pág. 11.
} 
afirmação pode parecer estranha por termos visto que, para Wood assim como para Marx, o segredo último da acumulação capitalista é político. Entendendo-se político neste caso como uma tentativa de controlar o processo por meio do Estado, não faria muito sentido falarmos de alienação. A nuvem talvez se dissipe ao entendermos o seguinte trecho;

A luta de classes figura com destaque em sua argumentação, como fizera nas de Dobb e Hilton; com Brenner, no entanto, não se trata de libertar um impulso para o capitalismo. Antes, trata-se de os senhores e os camponeses, em algumas condições específicas que foram peculiares da Inglaterra, dispararem involuntariamente uma dinâmica capitalista, enquanto, no conflito de classe uns com os outros, agiam no sentido de se reproduzirem como eram. A conseqüência não pretendida foi uma situação em que os produtores ficaram sujeitos aos imperativos do mercado ${ }^{25}$.

Se, por um lado, os produtores ficaram expostos à alienação característica da produção de mercadorias, por outro, isso foi conseqüência de suas próprias ações. Isso é claro na opinião de Wood. Por sua vez, Arrighi vê um comportamento propriamente capitalista a se generalizar de forma mais intencional. Essa diferença se deve a outras divergências teóricas. Por enquanto é importante destacar que estas duas visões apontam para aspectos complementares da luta de classes por meio do poder político do Estado.

Já vimos que a acumulação primitiva pode ser entendida como a posição das relações de mercado propriamente capitalistas, isto é, como a eliminação de separações pré-capitalistas ou não capitalistas que de alguma forma impediriam a efetivação das relações propriamente capitalistas. Como este processo de posição das relações capitalistas se dá pelo Estado, isto é por meios não capitalistas, ele pode ser caracterizado como uma acumulação política. Mas a acumulação política no sentido de acumulação primitiva torna efetiva a alienação, não apenas do trabalhador, mas também do capitalista e do próprio Estado. Tendo-se um entendimento rigoroso da questão das classes sociais no pensamento marxista - destacando-se a tradição iniciada por Lukács em História e Consciência de Classe - sabe-se que a classe, como presente na teoria de Marx define uma posição social dos agentes dentro da lógica de funcionamento do capital. É por isso que se diz que o capitalista é a personificação do capital e o proletário é a personificação do trabalho assalariado. É a partir desta idéia que Lukács desenvolve a sua argumentação sobre a

\footnotetext{
${ }^{25}$ Wood, 2001, pág. 52.
} 
consciência de classe do proletariado e do capitalista. A do proletariado por estar ligada a uma consideração da totalidade tende a se pôr contra o fetichismo - o que pode ser discutível. Já a do capitalista por estar ligada à sua condição contraditória de capitalista individual que personifica a lógica do capital em geral ao ser um fragmento dele que está em constante embate (por meio da concorrência) com os outros fragmentos (isto é, os outros capitais individuais), não só não tem a possibilidade de se pôr contra o fetichismo como tende a minar o seu próprio poder de classe. Neste sentido, não é de se estranhar que os capitalistas vivam numa condição na qual suas ações por dentro do Estado acabem lhes impondo um grau crescente de alienação em relação à reprodução do capital.

Desta forma, quando Belluzzo destaca que "submissão do trabalho, autonomização da estrutura técnica e, portanto, reversão das potencialidades do trabalho ao capital estabelecem a dominância da concorrência entre capitais sobre as relações entre capital e trabalho" isto não elimina a importância da luta de classes para se entender o capitalismo, mas, ao contrário põe a questão da luta de classes na concretude das relações capitalistas de produção. Isso significa demonstrar que a luta entre apropriadores e produtores $^{26}$ no capitalismo é mediada pelas relações capitalistas de produção. Ou seja, a dominação do capitalista sobre o trabalhador assalariado é condicionada pela relação entre este capitalista e toda a estrutura de reprodução do capital.

Mas como as relações de produção capitalistas são contraditórias e tendem a minar o próprio poder da classe capitalista e, principalmente, de muitos capitalistas individuais, a depender da lógica do capital a reprodução do poder de classe fica extremamente limitada o que impõe a permanência de outras formas de dominação, sendo o Estado uma das principais. É provavelmente considerando esta condição do capitalista que Lefebvre observa que "a burguesia e o modo de produção capitalista não coincidem, como acredita certo dogmatismo. Como se a equivalência entre burguesia e capitalismo ou entre relações de produção e modo de produção estivesse pré-fabricada. Como se a burguesia organizada em classe não fosse senão o 'sujeito’ do capitalismo. A burguesia ascendente não construiu o 'modo de produção' como tal, mas o Estado que lhe convinha"27. O Estado aparece, neste sentido, como um instrumento da reprodução dos conflitos de classe. Os trabalhadores e os capitalistas enquanto trabalhadores e capitalistas não têm a possibilidade de se tornarem sujeitos, pois são personificações do trabalho assalariado e do capital. Mas podem tentar fazê-lo, ao menos em parte, através do Estado e de outras formas de poder

\footnotetext{
${ }^{26}$ Forma como Wood (2003, pág. 73) define a luta de classes.

${ }^{27}$ Lefebvre, 2004.
} 
não capitalistas uma vez que as formas propriamente capitalistas significam, sempre, sujeição, fetichismo, alienação.

É neste caso que as ações estatais podem se realizar enquanto acumulação originária. Ou seja, ao invés de tais ações produzirem a efetivação das relações capitalistas, elas bloqueiam - ou procuram bloquear - esta efetivação, mantendo certos isolamentos, certas separações que isolam (em diversos graus) regiões ou setores das relações capitalistas de mercado. Neste sentido, “o Estado é exatamente o que a palavra sugere: um bastião contra a mudança, contra o fluxo do fazer, a encarnação da identidade" 28 .

Para finalizar esta seção é preciso destacar, em primeiro lugar, que estas formas de acumulação não capitalista - primitiva, originária e estatista - só estão sendo tratadas de forma tão estanque aqui pela necessidade de apreender o sentido específico de cada uma delas. Na prática, elas podem estar conjuntamente presentes nas posturas que o Estado toma diante do âmbito econômico. E nada melhor para demonstrar isso do que fazer uma referência - que até aqui estava pendente - à acumulação estatista. Como vimos no começo deste item, o Estado não é apenas produto da extração econômica do excedente e por ela determinado. Ele é também produtor das relações sociais que permitem a reprodução desta forma de exploração do trabalho. Portanto, a reprodução não é a reprodução apenas do capital. Ela é, igualmente, a reprodução das condições de poder do Estado. O Estado não age de fora da estrutura econômica e sim apenas como uma parte de um todo cindido, e, enquanto parte põe seus próprios fins (Lefebvre, Del'Etat). À busca de realização dos fins próprios ao Estado podemos denominar acumulação estatista.

Muitas vezes a acumulação estatista pode se referir a fins que não têm relação direta com as necessidades do capital - ao contrário do que ocorre no caso da acumulação primitiva e da acumulação originária - caracterizando-se como fins que interessam apenas ao próprio Estado. É possível mesmo que estes fins que interessam ao Estado sejam contrários à reprodução do capital. Mesmo sendo três formas de acumulação política, nem sempre a acumulação primitiva, a originária e a estatista coincidem, apesar disso ocorrer constantemente. O importante, no entanto, é perceber que há aí um desencontro possível. Afinal de contas, como vimos, a separação entre o político e o econômico não é uma autonomização entre ambos, mas, ao contrário, uma cisão entre a extração do excedente de forma econômica e a coerção política para que essa extração possa se efetivar. Esta

\footnotetext{
${ }^{28}$ Holloway, 2003, pág. 115
} 
separação é uma cisão na estrutura social de dominação da sociedade capitalista, a qual envolve tanto o Estado como o capital. É uma separação-na-união, de modo que ambos os lados mesmo tendo seus próprios interesses - o Estado procurando garantir seu poder de coerção e o capital procurando garantir a valorização do valor - têm, também, uma interdependência fundamental. Neste sentido, a separação entre ambos é algo próximo da cisão interna ao capital, isto é, uma situação crítica, na qual ora pode haver uma reprodução que promova os interesses do conjunto, ora esta reprodução pode revelar a cisão interna, geralmente de forma socialmente problemática, na explosão de uma crise. É o que veremos mais adiante.

\section{2 - O espaço e a acumulação}

Acima vimos o Estado não como um suporte exterior à acumulação de capital, mas como um elemento constitutivo desta, elemento sem o qual a produção e a reprodução da riqueza abstrata são impensáveis. Rigorosamente da mesma forma devemos entender o espaço. Não o espaço em geral, enquanto dimensão da realidade ou categoria do entendimento. $\mathrm{O}$ espaço enquanto espaço socialmente produzido. De forma sintética, o espaço enquanto produto e, ao mesmo tempo, condição da existência social. Uma porta de entrada que me parece bastante rica para refletirmos sobre esta condição do espaço social é a consideração de algumas idéias de Henri Lefebvre acerca do urbano. Para este autor, o urbano é produto e condição da acumulação. Enquanto produção de excedente que é, a acumulação possibilita o aparecimento da cidade, consumidora de parte do excedente produzido no campo, mas igualmente produtora, de relações sociais. A cidade é produto da forma urbana que é a forma da concentração, do encontro e da simultaneidade. Como põe Lefebvre;

A cidade atrai para si tudo o que nasce, da natureza e do trabalho, noutros lugares: frutos e objetos, produtos e produtores, obras e criações, atividades e situações. O que ela cria? Nada. Ela centraliza as criações. E, no entanto, ela cria tudo. Nada existe sem troca, sem aproximação, sem proximidade, isto é, sem relações. Ela cria uma situação, a situação urbana, onde as coisas diferentes advêm umas das outras e não existem separadamente, mas segundo as diferenças ${ }^{29}$.

\footnotetext{
${ }^{29}$ Lefebvre, 1999, pág. 111. [grifos meus]
} 
A simultaneidade é o que qualifica ações que ocorrem - ou coisas que existem - ao mesmo tempo. Mas a simultaneidade da forma urbana não se limita a essa ocorrência sincrônica, ela é qualitativamente diferente. Ao incluir como momentos determinantes de si não apenas a simultaneidade mas também a concentração, a forma urbana concentra coisas e ações que tinham uma existência simultânea mas isolada. É por isso que se deve considerar também o encontro como elemento da forma urbana, porque por meio dela aquilo que estava isolado, aquilo que estava separado, se encontra. Ao produto dessa confluência de elementos - simultaneidade, concentração, encontro - poderíamos nos referir como uma simultaneidade concreta, uma simultaneidade na qual as coisas e as ações estão imbricadas, existindo elementos individuais apenas dentro da relação. Esta é a situação urbana e é ela que faz a cidade passar da condição de produto à condição de produtora. E o que ela produz? Ela produz as relações, o entrelaçamento entre aquilo que estava isolado.

Se pode parecer um tanto confuso levar a discussão, de repente, para o tema do urbano sendo que até aqui ele não tinha aparecido, é preciso chamar a atenção para o fato de que Lefebvre encontrou na forma do urbano o elemento distintivo do espaço social em contraposição ao espaço da natureza, como é possível se verificar no seguinte trecho;
A forma do espaço social é o encontro, a concentração, a simultaneidade. $O$ que é que se concentra? $O$ que é que está concentrado? Tudo o que há no espaço, tudo o que é produzido seja pela natureza, seja pela sociedade - seja por sua cooperação, seja por seus conflitos. Tudo: seres vivos, coisas, objetos, obras, signos e símbolos. O espaço natureza justapõe, dispersa, ele coloca ao lado uns dos outros os lugares e quem os ocupa. Ele particulariza. O espaço social implica a concentração atual ou possível em um ponto, em torno desse ponto. Portanto, a acumulação possível (virtualidade que se realiza em certas condições $)^{30}$.

Ou seja, enquanto o espaço da natureza é o espaço da distância que separa, o espaço social é o espaço que une aquilo que estava separado. Na centralidade urbana é fácil se verificar esta eliminação da separação porque a cidade é justamente o ponto no qual tudo se concentra. Ali as coisas e as ações estão numa situação de co-incidência, de eliminação

\footnotetext{
${ }^{30}$ Lefebvre, A Produção do Espaço. [grifos meus]
} 
da distância. Mas como esta mesma condição a princípio própria da cidade passa a existir no espaço social em geral? Quando a cidade explode.

Marx ao tratar do capital vislumbrou sua presença em diferentes momentos da história (pré-capitalista) nos interstícios da sociedade, mas ainda não desenvolvido, ainda não dominante, nem sequer tendendo a constituir um mundo da mercadoria. De forma análoga, embora guardando suas diferenças, podemos tratar da forma urbana. Por muito tempo ela se limitou às poucas cidades, mas estava lá, marcando sua presença, marcando a possibilidade de uma sociedade urbana. Quando a acumulação vai se intensificando a concentração de elementos na cidade segue o mesmo caminho até que a cidade explode a partir de seu próprio centro, lançando para longe dela aquilo que antes estava restrito aos seus próprios limites. Utilizando uma metáfora emprestada da física por Lefebvre, a cidade implode e explode. Implode porque sofre uma concentração impossível de manter-se como con-centração, isto é, como existência conjunta num único centro e, desta forma explode lançado seus fragmentos - e sua centralidade - para um território mais amplo.

Este movimento de implosão-explosão nos revela um sentido geral e muito importante da produção do espaço social. Este é o sentido de expansão por sobre o espaço natural. Um crescimento de dentro para fora. É o movimento que demonstra como o espaço é produto e, ao mesmo tempo, condição da acumulação. Mas este movimento precisa, ainda, ser mais bem explicitado.

Por um lado, o espaço social é produto da acumulação porque ele próprio é produto do trabalho humano. Por esta condição, a produção do espaço social só pode ocorrer a partir do momento em que há produção de excedente de forma a liberar parte do trabalho social para se materializar em obras - barragens, canais de irrigação e/ou de navegação, estradas e as próprias cidades. Por outro lado, ele é condição da acumulação porque estas obras são as bases materiais da produção, quanto mais composto por melhoramentos mais o espaço se torna um meio para a acumulação e para se vencer as distâncias. O interessante de se notar neste movimento é que o espaço natural é sempre um meio ao qual o homem tem de se adaptar, é sempre uma determinação externa. É um meio que condiciona a produção. É um meio que condiciona a localização. Se é um meio hostil à produção ele a limita. E como o espaço natural é, em si, dimensão, distância, ele obstaculariza o deslocamento. Tanto num caso como noutro, o espaço natural aparece como espaço a ser vencido. O homem está separado da realização de seus objetivos pelo meio-obstáculo. 
Com a produção de um espaço social, o meio-obstáculo é virtualmente, em princípio, transformado num meio-facilitador. A separação posta pelo espaço natural tende a ser crescentemente minimizada pela produção deste espaço social. $\mathrm{Na}$ produção, os melhoramentos aumentam a produtividade do trabalho, possibilitando a expansão da produção, do excedente e, portanto, da acumulação. No deslocamento, as trilhas, as estradas e ferrovias se tornam meios de diminuir a distância. O espaço torna-se, portanto, um meio de minimizar a separação entre o ser humano e sua realização.

Dizendo assim parece que a produção do espaço social tende a possibilitar a liberdade do humano em relação ao natural de forma crescente e imediata (sem mediações contraditórias). No entanto, este percurso teórico posto acima foi apenas uma simplificação da questão. Alguns pontos importantes devem ser problematizados e discutidos, sendo o primeiro deles - que está ainda dentro da proposta do presente item - o da acumulação. Afinal, de que acumulação estamos falando?

A acumulação em geral pode ser entendida como resultado direto da produção de excedente. Mas se estivermos falando da acumulação capitalista estaremos lidando com a acumulação de riqueza abstrata. Esta constatação tem dois importantes significados. Em primeiro lugar, ela não se dá estritamente como acúmulo de riqueza material, mas sim como valorização do valor. Isso significa que se houver produção material e mesmo assim não se completar o processo de valorização do valor não houve acumulação capitalista. Em segundo lugar - e como conseqüência do que acaba de ser afirmado - a acumulação propriamente capitalista é diretamente determinada por um processo de alienação dos agentes com ela envolvidos.

Com isso é preciso entender que a acumulação capitalista não é apenas mais intensa que outras formas que possivelmente tenham existido. Ela é também qualitativamente diferente. Sendo fundamental buscar esta diferença numa reflexão sobre o sentido social desta forma de acumulação. Seria compreensível, por exemplo, que numa comunidade tradicional, de qualquer lugar do mundo e período histórico, as pessoas quisessem um aumento da produção para suprir suas necessidades e atender aos seus desejos. Talvez não seja tão problemático estudar esta tendência à acumulação de bens materiais em termos, digamos, mais antropológicos. Mas uma forma de acumulação que põe sua autoreprodução acima das necessidades sócias, podendo, inclusive, produzir crises na estrutura de reprodução social, não porque não se deu a produção material, mas porque não se deu a 
valorização do valor, não pode ser entendida como uma "tendência intrínseca ao ser humano em acumular". Por isso, ao lidar com esta forma de acumulação, penso ser necessário colocar em questão o porquê de sua existência e de sua permanência.

Bem, para começar, voltemos rapidamente aos comentários acerca do espaço social feitos no início deste item. Ali vimos que a forma do espaço social, segundo Lefebvre, é a forma do encontro, da concentração e da simultaneidade, ou seja, o que defini como simultaneidade concreta. Considerando a acumulação propriamente capitalista, como poderíamos entender este espaço como seu produto? Uma indicação neste sentido já foi feita ao se considerar o processo de implosão-explosão. Neste caso, a intensificação da acumulação faz com que haja uma expansão do espaço social sobre o espaço natural, da mesma maneira como a centralidade urbana tende a explodir e ser lançada a uma área cada vez maior. Mas nessa consideração fica algo ainda um tanto obscuro. Como e por que se dá esta intensificação da acumulação. Por que a acumulação explode?

O capital é marcado por uma cisão interna que o leva à necessidade de constante expansão. A reconstrução das consequiências desta condição crítica nos leva àquilo que Harvey chama de crises de sobreacumulação. Uma situação na qual o reinvestimento do capital não pode gerar o rendimento esperado. A fuga para uma situação como esta é uma fuga para fora, isto é, a expansão espacial dos investimentos.

A idéia de sobreacumulação de Harvey parece uma continuidade da de Lefebvre acerca do processo de implosão-explosão, com a diferença de que o primeiro está preocupado com a lógica contraditória interna ao capital, enquanto o segundo se refere à concentração de forma mais geral sem explicitar uma preocupação específica como a de Harvey. De uma forma ou de outra, aquilo que era próprio de uma centralidade inicial se expande por uma área cada vez maior. Para completar esta reflexão é preciso considerar dois detalhes interessantes.

Em primeiro lugar, as propriedades da centralidade urbana, sintetizadas na idéia de simultaneidade concreta, são fundamentais para a efetivação do capital, no sentido de gerarem as condições da concorrência. Aproveitando aquela passagem do texto de Lefebvre, é interessante perceber que a forma urbana é uma situação na qual "as coisas diferentes advêm umas das outras e não existem separadamente, mas segundo as diferenças". Nos termos do processo de posição do capital esta idéia é muito reveladora, 
pois trata precisamente da forma espacial que produz, entre outras coisas ${ }^{31}$, uma situação na qual cada capital individual passa a ter sua reprodução mediada pela relação com todos os outros, deixando de estar isolado em sua diferença particular.

Em segundo lugar, se o processo de implosão-explosão leva as mesmas características que eram próprias da centralidade urbana a espaços cada vez mais amplos, isso significa que aquela simultaneidade concreta vai se tornando cad vez mais ampla, eliminando o isolamento original entre um número crescente de lugares e, conseqüentemente, entre muitos capitais individuais. Haveria assim uma constante busca por parte dos capitais individuais de fugirem da sobreacumulação se expandindo espacialmente, o que, no entanto, tende a eliminar um certo isolamento espacial que, em certo sentido, lhes protegia da interação com outros tantos capitais. É desta situação que trata Arrighi no trecho a seguir;

Quando os centros de comércio e acumulação tentaram opor-se aos lucros decrescentes, através da diversificação de seus negócios, eles também aniquilaram a distância geográfica e funcional que os vinha mantendo fora do caminho uns dos outros, em mercados mais ou menos protegidos. Como resultado dessa dupla tendência, a cooperação entre os centros foi substituída por uma concorrência cada vez mais violenta... ${ }^{32}$

Como veremos, Arrighi trabalha com a idéia de que a história do capitalismo é composta por ciclos sistêmicos de acumulação, na sucessão destes ciclos há a presença, com intensidades variáveis, de duas lógicas de poder. Uma delas é a lógica territorialista e a outra a lógica capitalista. Na lógica territorialista o domínio político sobre áreas territoriais é o meio se reproduzir o poder. Na lógica capitalista a busca de formas comerciais, produtivas ou financeiras - para a valorização do capital torna-se este meio. No trecho acima, vê-se um momento a partir do qual a lógica capitalista terá de começar a predominar devido à minimização de uma proteção de caráter territorial que até então existia. Quando se encontram formas de isolamento espacial deste tipo, mesmo o poder econômico pode se reproduzir de formas que poderíamos entender como não propriamente capitalistas. É o que sugere Wood no trecho a seguir;

\footnotetext{
${ }^{31}$ Afinal não custa lembrar que Lefebvre não está se referindo apenas ao capital e também a outras formas de encontro, concentração e acumulação.

${ }^{32}$ Arrighi, 1996, pág. 232.
} 
Tomemos o exemplo do comércio de longa distância, a forma particular de atividade econômica que definiu os grandes centros comerciais que, segundo todas as versões do modelo mercantil, teriam sido os precursores do capitalismo. Este tipo de comércio assumia a forma de uma "arbitragem comercial entre mercados separados". Comprar barato num mercado e vender caro em outro era o princípio operacional, e não a competição num único mercado integrado. Se havia competição, ela não assumia a forma de uma produção competitiva e eficiente em termos de custos. Certas condições essencialmente "extraeconômicas", como a dominação dos mares e outras vias de transporte, ou instituições financeiras e instrumentos de arbitragem altamente desenvolvidos, eram a chave da vantagem comercial ${ }^{33}$.

Como já vimos, Wood critica muitos estudiosos do capitalismo por não darem atenção aos processos que promoveram a sua origem, o que em geral cria a impressão de que o capitalismo é apenas uma continuidade de processos anteriores de acumulação. $\mathrm{O}$ problema é que assim se perde a noção da especificidade do capitalismo. O exemplo do comércio de longa distância nos é muito útil porque se refere a uma atividade econômica em geral vista como capitalista ou como produtora do capitalismo. Algumas posições de Wood podem soar um tanto extremadas em relação à origem do capitalismo, como quando, conforme já apontei, a autora afirma que talvez nunca existisse capitalismo não fosse o seu surgimento no campo inglês. E neste sentido provavelmente tenha que se reconhecer o comércio de longa distância realizado pelos comerciantes italianos como um dos elementos que dá origem ao capitalismo. No entanto, a ligação entre um momento e outro não pode ser realmente imediata. Mesmo que ambos - comércio de longa distância e capitalismo propriamente dito - estejam ligados ao acúmulo de riqueza monetária, por exemplo, as condições de produção e realização dessa riqueza não são idênticas nos dois casos.

Enquanto no comércio de longa distância o que possibilita o lucro são formas não econômicas ligadas ao domínio territorial e possibilitadas pela distância espacial existente entre o lugar da compra e o lugar da venda, no capitalismo, como o definimos o lucro é determinado pela lógica da riqueza abstrata, o que significa que só pode se dar se os capitais individuais buscarem constantemente o aumento de produtividade. A diferença do lucro no primeiro caso para o lucro no segundo é que o primeiro está ligado ao isolamento espacial, enquanto o segundo está ligado à minimização deste isolamento. Em mais uma

\footnotetext{
${ }^{33}$ Wood, 2001, pág. 80.
} 
referência à obra de Wood, é interessante notar que quando esta autora busca as origens do capitalismo no campo inglês, entendo que esta origem está ligada à transformação do mercado em um conjunto de coações sobre os produtores, um dos elementos por ela destacados é, justamente, a produção de um espaço que promove a integração entre os lugares, como é possível se verificar no trecho a seguir;

A centralização política singular do Estado inglês tinha bases $e$ corolários materiais. Já no século XVI, a Inglaterra dispunha de uma rede impressionante de estradas e transporte de água, que unificou a nação num grau incomum na época. Londres, que se tornou desproporcionalmente grande em relação a outras cidades inglesas e à população total do país (e, eventualmente, a maior cidade da Europa), também vinha se transformando no eixo de um mercado nacional em desenvolvimento ${ }^{34}$.

É inevitável relembrar as palavras de Lefebvre na primeira citação deste item, quando, após se referir à cidade como produto da concentração se pergunta: "O que ela cria?" e ao responder afirma: "Nada. Ela centraliza as criações. E, no entanto, ela cria tudo. Nada existe sem troca, sem aproximação, sem proximidade, isto é, sem relações". Segundo Wood o que está ocorrendo na Inglaterra durante o século XVI é, justamente, a concentração cada vez mais intensa de Londres sobre áreas cada vez mais vastas do território. Este processo, por sua vez produz o mercado como coação sobre os produtores agrícolas que passaram a ter de concorrer entre si com o intuito de garantir seus rendimentos e, desta forma, sua reprodução enquanto produtores. Essa concorrência, estabelecida a partir da integração espacial, leva a um constante aumento de produtividade que passará a pressionar, posteriormente, os produtores do restante da Europa, conforme for se intensificando a integração espacial entre as Ilhas Britânicas e o continente. O que se destaca nessa argumentação é a importância da integração espacial para o estabelecimento de relações de concorrência que, por sua vez, efetivam a lógica do capital. Harvey argumenta no mesmo sentido ao criticar a idéia de capitalismo concorrencial como referência à economia capitalista que existia por volta de 1840. Segue seu argumento:

Uma coisa é destacar a pequena escala das empresas e a fragmentação da atividade econômica, e outra supor que isto trazia consigo uma concorrência perfeita, a igualação dos preços e dos lucros. As variações

\footnotetext{
${ }^{34}$ Wood, 2001, pág. 82.
} 
dos preços de uma localidade a outra eram muito marcadas. Ainda que não existam muitos estudos sistemáticos sobre as diferenças nas taxas de lucro, as provas que temos indicam que variavam muito de uma empresa para outra, de uma indústria à outra e de um lugar a outro. Os mecanismos para compensar os preços e os lucros por meio da concorrência eram qualquer coisa, menos perfeitos, e a migração do trabalho era casual no melhor dos casos. Não é difícil ver porque isto sucedia.

Para começar, os custos de transporte eram relativamente altos e a integração espacial das economias nacionais, e nem digamos da economia internacional, estava em suas etapas mais primitivas. As empresas muito pequenas podiam funcionar como monopólios no mercado local que controlavam. Os custos de transação eram relativamente altos em relação ao volume e ao valor, enquanto o fluxo de informação era lento, esporádico e incompleto com respeito aos movimentos de preços, às oportunidades de lucro, às técnicas de produção, etc $^{35}$.

Percebe-se que fatores fundamentais para que a lógica capitalista propriamente dita se ponha eram, para dizer pouco, insuficientes nesse período. Com variações de preços de uma região para outra, garantidas justamente pela separação espacial, como se pode falar de valor de troca e de tempo de trabalho socialmente necessário? Ao mesmo tempo vimos no item 3.3, por exemplo, como a equalização das taxas de lucro é fundamental para se entender a problemática da transformação dos valores em preços de produção e que é justamente, assim como o importante papel que esta transformação tem para que o capital seja uma relação social que promove o impulso na direção do aumento de produtividade. Sem estas e outras condições fica difícil se afirmar, portanto, que o capital está posto, o que torna inevitável perceber a predominância de formas não capitalistas de dominação, sendo o isolamento espacial uma das mais importantes. Veltz se refere descreve esta situação da seguinte forma.

Um mundo "bem organizado" pela proximidade e pela distância geométrica. Num universo de transportes lentos e custosos, este tipo de ordem é evidente: as relações sociais ou econômicas de primeira ordem são sempre as relações de proximidade. Os espaços estão claramente

${ }^{35}$ Harvey, 1990, pág. 150. 
escalonados e incluídos uns nos outros, como bem mostra Braudel [Civilização Material, Economia e Capitalismo séc. XV-XVIII: O Tempo do Mundo]. Os grandes centros têm precisamente como função articular os espaços de proximidade e os mundos distantes, construindo e explorando essas enormes diferenças de potencial que constituem sua riqueza e sua capacidade de dominação ${ }^{36}$.

É interessante ressaltar que da mesma forma que aponta Wood em citação anterior, o poder de dominação está ligado à capacidade dos grandes centros em articular espaços isolados. Como vemos, portanto, não se pode desconsiderar o papel da separação própria ao espaço natural como fundamento da organização social em épocas passadas. É claro que igualmente não se pode afirmar que este papel acabou de forma generalizada, o que seria cair no discurso do mundo interligado e sem fronteiras. Mas de qualquer forma, é importante perceber que a produção do espaço social minimiza este papel. Em relação à análise da acumulação capitalista podemos dizer, ainda de forma preliminar, que esta produção minimização tende a efetivar o capital, a pôr o capital como relação social, o que se dá num processo que deve ser entendido como uma substituição da separação própria do espaço natural por uma separação própria do capital. Isto é, se num primeiro momento a distância é predominante enquanto mediação para as relações sociais, a minimização das distâncias relativas se dá efetivando a condição do capital como mediação para tais relações. E por isso, acredito que podemos afirmar que a produção do espaço social, nestes termos, funciona como um processo de acumulação primitiva, posto que é um pressuposto para a acumulação propriamente capitalista.

Elementos terão de ser trabalhados mais à frente de modo que fique claro que este movimento de efetivação do capital não se dá de forma linear e contínua, apresentando, isto sim, continuidades e descontinuidades. Por enquanto, já se faz necessário um aprofundamento nesta reflexão sobre este mecanismo de acumulação primitiva que é a produção do espaço. O que discutimos até aqui como produção do espaço promovendo acumulação primitiva carece de um entendimento mais rico sobre o próprio espaço. Como meio de chegar até isso, vejamos esse comentário de Lefebvre;

O espaço aparece como objetividade, mas não existe socialmente senão para a atividade (para e pelo mercado, os deslocamentos a cavalo, de veículo automotor, de barco, de trem, por avião). Por um lado, ele

\footnotetext{
${ }^{36}$ Veltz, 1999, pág, 58.
} 
oferece direções homólogas, e por outro, certas direções valorizadas. De igual modo, para os ângulos e rotações (à esquerda, sinistra - à direta, retidão). De uma parte, o espaço se quer homogêneo, aberto às ações racionais, autorizadas ou comandadas; de outra parte, ele se encarrega de proibições de qualidades ocultas, de favores e desfavores para os indivíduos e seus grupos $^{37}$.

A idéia de que o espaço é distância não é errada, mas é insuficiente. Como a Geografia vem demonstrando pelo menos desde sua renovação das décadas de 1950 e 1960 - e provavelmente antes mesmo disso ${ }^{38}$ - o espaço, mesmo o natural, não pode ser considerado estritamente em termos de distância. O espaço não é apenas o meio entre dois pontos, mas também os elementos - naturais ou sociais - que o formam. Estes elementos fazem do espaço um meio não neutro, não homogêneo, cheio de "normas ocultas". E, para enriquecer ainda mais a discussão, em termos sociais o espaço não se reduz à sua materialidade, sendo composto igualmente de normatizações de regras de uso postas pelos mais diversos âmbitos reguladores, desde os mais tradicionais como as comunidades locais até o Estado e para além dele no âmbito do sistema interestatal. Com estas considerações, o espaço como meio a ser vencido para a integração em nome da efetivação do capital é um conjunto bem mais complexo de elementos do que a mera distância geométrica.

Isso, no entanto, não significa que o espaço não seja integrado à reprodução do capital, mas sim que esta integração envolve outros elementos de produção do espaço que não apenas a geração de meios de transporte e comunicação interligando os lugares. O que é preciso perceber é que além da distância geométrica os outros elementos constituintes do espaço também podem se pôr como obstáculos que impedem ou dificultam a efetivação do capital. Existiriam, seguindo este raciocínio, outras formas de separação espacial para além da pura distância. Para dar um exemplo óbvio, quando os colonizadores europeus chegaram às Américas elas não estavam imediatamente integradas ao capitalismo europeu nascente. E isso não só porque as caravelas fossem lentas e pouco eficientes, mas porque o espaço aqui existente estava repleto de conteúdos que se não fossem eliminados manteriam estas terras isoladas da Europa. Estes conteúdos eram, entre tantos outros, as populações nativas, seus costumes, suas formas de organizar o espaço natural e a própria ocupação

\footnotetext{
${ }^{37}$ Lefebvre, Produção do espaço.

${ }^{38}$ Como sugere Damiani (2004), nem a Geografia Tradicional considerou o espaço como vazio e geométrico, apenas as banalizações desta é que o fizeram.
} 
deste espaço pelos seus corpos. Tudo isso foi eliminado em nome da integração espacial das Américas ao capitalismo europeu.

Assim sendo, acumulação primitiva em termos espaciais é um processo muito mais amplo do que a eliminação da distância geométrica. É, principalmente, a transformação de um espaço repleto de conteúdos em um espaço vazio e simplesmente geométrico. É isso que nos ensina Damiani, se referindo às idéias de Lefebvre, no seguinte trecho;

Trata-se de retirar as referências sociais, culturais e naturais, mesmo as economicas que preenchem um espaço, e lhe conferem uma qualidade particular. Retirar dele a historicidade viva, negá-la, de forma absoluta, criando os pressupostos para a instauração e desenvolvimento de novos processos, estes próprios do desenvolvimento capitalista, portanto próprios à racionalidade da mercadoria, do mundo da mercadoria. Essa varredura repõe como existência não só lógica, mas como presença real, o espaço geométrico como pressuposto histórico do processo em curso: há evidências indicando essa anulação de conteúdos precedentes com o processo de capitalização. Essa acumulação primitiva é, também, simultânea às condições de desenvolvimento do capitalismo. $O$ tempo todo se recoloca a necessidade de constituição desse esvaziamento primevo $^{39}$.

Como está sugerido neste trecho - e como já vimos no início deste capítulo - a acumulação primitiva não é algo datado na história do capitalismo, mas sim um processo não capitalista que funciona como um pressuposto da acumulação capitalista. Neste sentido, não é apenas possível, mas uma tendência constante, que formações espaciais produzidas no próprio contexto de expansão do capitalismo tenham de ser re-produzidas para a continuidade da acumulação. Harvey (1990 e 2004) dá exemplos interessantes que demonstram, inclusive, que o próprio capitalismo gera obstáculos à continuidade da acumulação. Um deles é o do capital fixo, que uma vez materializado no espaço enrijece as relações sociais que ali se dão, funcionando enquanto norma de ação e, neste caso, como obstáculo, como separação externa ao capital. Quer dizer, neste caso, algo que foi produzido como mediação interna ao capital com o tempo pode se tornar externa a ele.

\footnotetext{
${ }^{39}$ Damiani, 2004, pág. 80.
} 
O mesmo pode ocorrer com os elementos não materiais constituintes do espaço. Podem ser produzidos num determinado momento como forma de impor às ações que se darão num determinado espaço a mediação propriamente capitalista, mas posteriormente esta mediação pode se tornar externa ao próprio capital. Externa no sentido se virar um obstáculo à própria reprodução do capital. A CLT é um caso interessante no Brasil. Feita num momento em que a economia brasileira se integrava ao capitalismo industrial, tornase um obstáculo no momento em que o Brasil tenta se integrar ao que alguns entendem como capitalismo financeiro, financeirizado ou flexível. Mas um exemplo ainda mais interessante é o da transformação do solo urbano em propriedade privada. Num primeiro momento, o uso do solo passa a ser mediado pela forma da propriedade privada integrando-se à reprodução capitalista. $\mathrm{O}$ crescimento da cidade torna o solo urbano principalmente aquele que tem certas condições de localização - raro e, portanto, muito caro, a ponto de se pôr como limite à própria reprodução capitalista. É o que sugere Carlos no seguinte trecho:

No momento atual do processo histórico, do ponto de vista da reprodução do capital, o processo de reprodução espacial, com a generalização da urbanização, produz, uma nova contradição: aquela que se refere a diferença entre a antiga possibilidade de ocupar áreas como lugares de expansão da mancha urbana (com o parcelamento de antigas chácaras ou fazendas, como o caso de muitos bairros na metrópole paulista) e sua presente impossibilidade diante da escassez de áreas. Isto porque o espaço, enquanto valor, entra no circuito da troca geral da sociedade (produção/repartição/distribuição) fazendo parte da reprodução da riqueza, constituindo-se em raridade. Por outro lado, vivemos, hoje, um momento do processo de reprodução em que a propriedade privada do solo urbano - condição da reprodução da cidade no capitalismo passa a ser um limite a expansão econômica capitalista. Isto é, diante das necessidades impostas pela reprodução do capital, o espaço produzido socialmente - e tornado mercadoria, no processo histórico - é apropriado privativamente, criando limites a sua própria reprodução. Nesse momento, o espaço, produto da reprodução da sociedade, entra em contradição com as necessidades do desenvolvimento do próprio capital. $O$ que significa dizer que a "raridade" é produto do próprio processo de produção do espaço ao 
mesmo tempo que sua limitação - o que se configura como uma contradição do espaço ${ }^{40}$.

As infra-estruturas territoriais, as leis trabalhistas válidas num território ou a própria propriedade privada do solo urbano se constituem como contradições do espaço por serem incorporadas a ele e tornarem-se, desta forma, seus elementos constitutivos. As formas não capitalistas de eliminação destes meios podem ser entendidas como formas de acumulação primitiva, mesmo que ocorram no presente, posto que sua função é produzir, ou no caso, re-produzir as condições para a acumulação capitalista. Sobre algumas destas formas não capitalistas é que falarei a seguir.

\footnotetext{
${ }^{40}$ Carlos, 2001.
} 


\section{5 - Estado, espaço e acumulação}

Fronteiras interiores e invisíveis começam a partilhar o espaço, dominado, no entanto, por uma estratégia global e por um poder único.

Henri Lefebvre, A produção do espaço

As relações entre Estado, espaço e acumulação se dão em diversos âmbitos e em variadas escalas espaciais. Pode-se tratar tanto das pretensões de um determinado Estado em se pôr como potência hegemônica em escala planetária como da implementação de um projeto de orçamento participativo em uma pequena cidade do interior. Em princípio nestes e noutros tantos casos se poderiam encontrar alguns elementos constantes na determinação das relações entre Estado, espaço e acumulação, de modo que seria possível promover uma reflexão geral acerca de tais relações. No entanto, entendo que em cada caso específico, em cada escala e em cada âmbito de atuação, se revelam com maior ou menor intensidade elementos diferentes que nos permitem entender melhor este ou aquele aspecto desse conjunto. Neste trabalho, optei por problematizar as relações entre o Estado, o espaço e a acumulação por meio do território nacional e, portanto, do Estado e da economia nacionais, tendo como foco as mudanças que caracterizaram o que se convencionou chamar de reinserção do Brasil na economia mundial. As reflexões feitas até aqui tiveram como principal objetivo colaborar para o entendimento desta problemática, que será desenvolvida a seguir, mesmo que sem o aprofundamento empírico e analítico que se pretendia inicialmente.

\section{1 - Estado e capital em meio à problemática espacial: a dupla crise}

A separação entre o político e o econômico que marca o capitalismo e que é a base para a delimitação entre capital e Estado, foi vista como uma condição crítica no sentido de que cada um dos dois âmbitos passa a ter interesses que lhe são próprios - o Estado busca reafirmar seu poder e o capital promover a valorização - mas que, ao mesmo tempo, só são realizáveis por meio da atuação do outro. O poder estatal depende da extração de excedente que passa a ser promovida de forma puramente econômica pelo capital. Esta 
extração, por sua vez, depende de que o poder político produza e re-produza seus pressupostos. Esta situação crítica ganha todo o seu sentido quando introduzimos na reflexão a problemática espacial. E isso não é - assim espero - uma tendência geograficizante, mas simplesmente uma constatação fundamental, a de que o Estado (moderno) só existe como Estado nacional, enquanto o capital desde o seu nascimento é transnacional.

Esta constatação colabora diretamente com a apreensão daquele sentido crítico da separação entre o Estado e o capital por nos levar à percepção de que tal separação implica também uma disjunção entre o econômico e o espacial. Após a dita separação o Estado, por sua própria natureza de instituição que exerce o poder sobre determinada área, permanece preso ao espaço. Por sua vez, o capital se forma a partir da libertação da riqueza em relação a um espaço específico. A desconsideração desta disjunção impõe sérios limites ao entendimento tanto do Estado, como do capital e da produção do espaço. Por exemplo, como chama a atenção Holloway;

\footnotetext{
"a suposição de que Estado e sociedade são coextensivos dissimula o fato de que o que distingue o capital como forma de dominação em relação a formas prévias de dominação é, principalmente, sua mobilidade essencial" ${ }^{\prime \prime}$
}

Em várias de suas obras - entre elas A produção do Espaço, A Revolução Urbana e Del' Etat - Lefebvre destaca a importância do processo de abstração da riqueza no rico sentido da passagem da riqueza fundiária à riqueza mobiliária. Esta passagem é uma transmutação da riqueza muito mais profunda e significante do que normalmente se imagina a priori. Não se pode confundi-la, por exemplo, com a diferença que existe entre o dinheiro investido em imóveis e o dinheiro em espécie após a venda destes imóveis. Não há dúvida de que o investimento de uma soma de dinheiro na compra de um imóvel promove uma certa imobilidade desta riqueza, posto que é preciso vender o imóvel para poder transportá-la, não se podendo transportar o próprio imóvel, ao contrário do que se poderia fazer, por exemplo, com mercadorias produzidas com aquele dinheiro. No entanto, a própria possibilidade de vender o imóvel, de trocá-lo por dinheiro e poder transportar este dinheiro significa que houve a passagem da riqueza fundiária à riqueza mobiliária, isto é, deu-se a abstração da riqueza. Isto porque esta venda do imóvel só é possível graças à

\footnotetext{
${ }^{1}$ Holloway, 2003, pág. 145
} 
transformação do solo em mercadoria, ou seja, em algo que pode ser trocado pelo representante universal da riqueza abstrata, o dinheiro.

A abstração da riqueza de que fala Lefebvre inclui, justamente, aquela disjunção entre o econômico e o espacial, mas tem conseqüências que ainda precisam ser esclarecidas. Quando tratei da abstração da riqueza no capítulo 3 esta abstração indicava um processo de alienação dos produtores da riqueza - assim como dos detentores do comando desta produção - em função da mediação exercida pelas condições do mercado capitalista entre a produção e a realização desta riqueza. Agora, novamente é preciso indicar o sentido da abstração da riqueza como alienação. Este sentido aparece, por exemplo, no seguinte comentário de Holloway;

Na realidade, o que o Estado faz está limitado pelo fato de que existe só como um nó em uma rede de relações sociais, que se centra de maneira crucial, na forma em que o trabalho está organizado. O fato de o trabalho estar organizado sobre uma base capitalista significa que o que o Estado faz e pode fazer está limitado pela necessidade de manter o sistema de organização capitalista do qual é parte. Isso significa concretamente que qualquer governo que realize uma ação significativa contra os interesses do capital terá como resultado uma crise econômica e a fuga do capital do território estatal ${ }^{2}$.

A abstração da riqueza como conseqüência da exacerbação da separação entre o político e o econômico significa, portanto, alienação do Estado, mediação do político pelo econômico, segundo as condições do mercado capitalista. Mas é preciso tomar cuidado. A constatação desta alienação do Estado em relação ao capital não pode nos levar a duas simplificações recorrentes. Em primeiro lugar a de que há uma completa libertação do capital em relação ao espaço. Em segundo a de que há aí um domínio pleno dos capitais individuais. Sobre o primeiro equívoco vejamos a seguinte afirmação de Holloway;

As discussões atuais sobre a "globalização" apenas ressaltam o que sempre foi certo: as relações sociais capitalistas, por natureza, sempre foram mais além dos limites territoriais, a característica distintiva do capitalismo é que liberou a exploração desses limites territoriais, em virtude de que a relação entre o capitalista e o trabalhador é mediada pelo dinheiro. E essa mediação significa uma completa

\footnotetext{
${ }^{2}$ Holloway, 2003, pág. 26
} 
desterritorialização dessas relações: não existe razão para que o empregador e o empregado, o produtor e o consumidor, ou os trabalhadores que cooperam no próprio processo de produção devessem estar no mesmo território ${ }^{3}$.

Ao falar de uma "completa desterritorialização" das relações de exploração Holloway se arrisca a parecer sugerir que o capital não precisa mais se territorializar em lugar nenhum se tornando absolutamente livre da dimensão espacial. Não é essa sua pretensão e lendo o restante de seu texto percebe-se isso facilmente. Na realidade, por não ter como preocupação central uma reflexão sobre as relações entre o capital e o território, este autor não chega a delimitar melhor o que seria um processo de territorialização. Mesmo assim, penso que é possível e necessário apreendermos o sentido geral do que seria para ele um tal processo a partir da forma como se refere à desterritorialização. Para Holloway, a desterritorialização do capital significa a liberdade dos capitais individuais em relação a um território específico, tido, portanto, como o espaço delimitado pelas fronteiras de um Estado nacional. A desterritorialização significaria, desta forma, simplesmente uma liberdade maior para estes capitais se localizarem, num território ou em outros. Mas afinal, continua existindo a necessidade de se localizarem em algum território, não? Sem dúvida. E o interessante, a partir do que já vimos, é que isto se refere não apenas à necessidade de ter um espaço enquanto "apoio" material para realizar suas atividades, mas ter de se inserir em uma situação que envolve múltiplos elementos - naturais, culturais, econômicos, políticos... - que compõem o espaço como espaço social. Para além do espaço como puro apoio, como mera extensão, muitos destes outros elementos são em parte obstáculos à reprodução do capital e, em parte, necessários a ela, o que pode mudar conforme as condições do mercado. Neste sentido, parece que a busca dos capitais individuais não é realmente por uma desterritorialização absoluta, mas por uma liberdade de territorializar-se conforme suas próprias necessidades de reprodução. É o que podemos verificar na seguinte observação feita pelo, então, presidente da companhia Dow Chemical, Carl Gerstacher, segundo citação feita por Arrighi;

Há muito tempo eu sonho comprar uma ilha que não pertença a nação alguma [...] e estabelecer a sede mundial da Dow Company no terreno realmente neutro dessa ilha, não comprometida com nenhuma nação ou sociedade. Se nos localizássemos no terreno realmente neutro da ilha assim poderíamos realmente operar nos Estados Unidos como cidadãos

\footnotetext{
${ }^{3}$ Holloway, 2003, pág. 28
} 
norte-americanos, no Brasil como cidadãos brasileiros, no Japão como japoneses, em vez de ser primordialmente regidos pelas leis dos Estados Unidos. [...] Poderíamos até pagar altas somas de dinheiro a qualquer nativo para que se mudasse para outro lugar ${ }^{4}$.

Conforme esta idéia há, realmente, uma necessidade de localização por parte dos capitais individuais, por um lado e, por outro, uma busca por não se submeter a um certo condicionamento que a localização em um determinado lugar pode exigir. É uma busca por libertar-se do espaço não de forma a deixar de utilizá-lo, mas de forma a impor sobre ele as suas próprias necessidades, os seus próprios fins. Uma busca, aliás, bastante antiga, já presente, em certo sentido, no embate entre a indústria e a natureza como aponta Lefebvre no seguinte trecho:

A agricultura se instala na natureza. Ela produz segundo a Physis, conduzindo-a mais do que a obrigando. Se o movimento da Physis da do germe à flor e ao fruto, e assim recomeçando o ciclo, o espaço e o tempo camponeses não rompem esse ciclo, eles se inserem nele. [...] A indústria, por sua vez, captura a natureza e não a respeita; dispende suas energias; ela a desventura para apoderar-se de seus recursos em energia e em matéria; a devasta para produzir coisas (intercambiáveis, vendáveis) que não são da natureza nem estão nela. A indústria não permanece submetida ao lugar e, não obstante, depende dele. Se tende a ocupar o conjunto de um território, só o faz reunindo fragmentos dispersos, as empresas, pelo mercado ${ }^{5}$.

Esta mesma relação entre a indústria e a natureza, apontada por Lefebvre, está presente na relação entre qualquer forma de capital e o espaço social. Os capitais individuais têm de se localizar, mas, ao mesmo tempo, não podem se submeter ao lugar. Ora, o lugar é um ponto do espaço social, constituído por uma multiplicidade de elementos. Alguns destes elementos são fundamentais para a reprodução destes capitais enquanto outros podem apresentar-se como obstáculos, considerando, ainda, que com as transformações que o capitalismo vai sofrendo ao longo do tempo, a condição de cada um destes elementos pode mudar. Se num primeiro momento a tradição, por exemplo, pode ser

\footnotetext{
${ }^{4}$ Arrighi, 1996, pág. 82.

${ }^{5}$ Lefebvre, 1999, pág. 110. - Grifos meus.
} 
estranha à lógica da acumulação ligada à indústria, mais tarde os investimentos em atividades turísticas podem procurar retomá-la como espetáculo ${ }^{6}$.

De qualquer forma, há uma situação paradoxal. Os capitais precisam se localizar e, ao mesmo tempo, não devem se submeter ao lugar. Nesta situação sua busca é a de incorporar os elementos que lhe possam ser úteis para a reprodução e, ao mesmo tempo, evitar que esta seja intermediada por aqueles elementos estranhos à lógica da acumulação da riqueza abstrata. Ou pelo menos que lhe sejam estranhos naquele momento. Esta localização seletiva só pode se dar por meio de formas de acumulação primitiva. Ou seja, é preciso preparar o terreno para o capital se instalar. Mas se considerarmos que a acumulação primitiva como uma forma de acumulação não econômica que gera os pressupostos para a acumulação propriamente econômica, propriamente capitalista, é preciso atentar para o fato de que os capitais individuais não podem realizar esta função, pelo menos não de forma capitalista. Esta constatação nos remete à simplificação acerca da abstração da riqueza, qual seja, a de que haveria um domínio pleno destes capitais sobre o Estado. Esta simplificação é altamente recorrente em nossa época, em particular como referência ao neoliberalismo como se fosse um modelo econômico no qual o Estado se retira da economia, a qual passaria a funcionar somente com a regulação automática do mercado.

Para discutirmos mais a fundo esta questão retomemos a declaração do presidente da companhia Dow Chemical, segundo a qual ele gostaria de comprar uma ilha para poder atuar em cada país como se fosse cidadão daquele país. $\mathrm{O}$ interessante é que a opção pela ilha não significa atuar somente nela, onde a empresa estaria livre do Estado, mas sim poder, a partir da ilha, escolher os Estados nacionais nos quais seria melhor atuar. E por que se torna tão importante esta liberdade afinal? Justamente porque enquanto capital individual que é a empresa Dow Chemical, precisa buscar as melhores opções de localização de forma a promover uma atuação tão ou mais eficiente que seus concorrentes. Ao não fazê-lo ela estaria correndo o risco de não conseguir completar o percurso entre a produção e a realização da riqueza, percurso esse mediado pelas condições do mercado capitalista.

\footnotetext{
${ }^{6}$ Seguindo aqui a noção de espetáculo de Guy Debord. Neste caso, algo - a tradição - que é separado de seu sentido original e posto num novo contexto, sendo então um fragmento comandado por uma nova lógica unificadora que não é mais aquela que lhe era própria quando sua condição não era de fragmento.
} 
Portanto, a exacerbação da separação entre o político e o econômico que leva à passagem da riqueza fundiária à mobiliária, isto é, à abstração da riqueza, significa também a necessidade posta aos capitais individuais de buscarem boas localizações sob pena de não conseguirem cumprir o percurso entre a produção e a realização da riqueza conforme suas necessidades de reprodução. Esta condição crítica na qual estão envolvidos o econômico, o político e o espaço é a posição do capital no sentido da produção da alienação, seja para o Estado, seja para os capitais individuais. Nesta situação os Estados nacionais têm de agir no sentido de atrair e manter capitais em seu território, enquanto os capitais individuais têm de buscar territórios para se localizarem. Os capitais buscam localizações ideais, as quais não lhe afetem a reprodução. Há, aí, uma relação conflituosa entre os Estados nacionais e os capitais individuais, a qual se reflete em grande parte na problemática do território nacional.

\section{2 - Território e territorialização}

Por meio do conceito de território podemos explorar a relação entre o Estado nacional, o espaço e a acumulação. Se em geral podemos entender que o Estado tem como especificidade a busca por efetivar seu poder de coerção ou de regulação (o que seria uma outra forma de coerção), quando nos referimos à existência concreta do Estado, isto é, ao Estado nacional, é importante perceber que essa efetivação do poder tem de ocorrer sobre uma determinada porção de espaço, à qual denominamos como território nacional. Esta porção é delimitada no contexto do sistema interestatal, dentro do qual se consolida a forma moderna de Estado, o Estado nacional ou territorial. Parte da relação deste Estado com o espaço pode ser apreendida por meio da diferenciação entre fronteira e limite feita por Lia Osório Machado, conforme vai se estabelecendo no seguinte trecho;

A palavra fronteira implica, historicamente aquilo que sua etimologia sugere - o que está na frente. A origem histórica da palavra mostra que seu uso não estava associado a nenhum conceito legal e que não era um conceito essencial político ou intelectual. Nasceu como um fenômeno da vida social espontânea, indicando a margem do mundo habitado. Na medida que os padrões de civilização foram se desenvolvendo acima do nível de subsistência, as fronteiras entre ecúmenos tornaram-se lugares de comunicação e, por conseguinte, adquiriram um caráter político. Mesmo assim, não tinha a conotação de uma área ou zona que marcasse o limite definido ou fim de uma unidade política. Na realidade, o sentido 
de fronteira era não de fim mas de começo do Estado, o lugar para onde ele tendia a se expandir ${ }^{7}$.

Esta condição da fronteira como o lugar para o qual o Estado tendia a se expandir relativiza aquela afirmação feita anteriormente sobre a fixidez do Estado a uma determinada localização, em contraposição aos capitais individuais que teriam liberdade de deslocamento. Mas nem poderia ser diferente, Machado se refere neste caso a um Estado pré-capitalista. Em tais condições dois elementos fundamentais do capitalismo não estão estabelecidos. Primeiro, não está clara a separação entre o político e o econômico, de forma que grande parte da reprodução econômica está sob o controle do próprio Estado e daí a sua tendência - assim como sua possibilidade e sua necessidade - em se expandir. É o que encontramos, por exemplo, de forma mais clara nos impérios da antiguidade ou mesmo - apesar de já com certas descontinuidades - no início da expansão marítima européia. A separação entre o político e o econômico é fundamental para a efetivação do capitalismo para que os agentes econômicos possam e devam atuar segundo a lógica da riqueza abstrata, vendo-se relativamente autônomos em relação a um determinado Estado e aos requisitos estatistas. Segundo, o sistema interestatal não está ainda estabelecido. Seu estabelecimento se dá, segundo Arrighi (1996), durante a hegemonia holandesa e é simbolizado pelo Tratado de Vestfália (1648). A partir de tal tratado duas novidades nas relações entre o âmbito político e o econômico começaram a se desenvolver cada vez mais.

Em primeiro lugar se produziu o mútuo reconhecimento da soberania dos Estados nacionais num contexto em que eles passam a compor um sistema no qual os territórios são mutuamente excludentes. Logicamente este reconhecimento não foi definitivo, mas por certo tempo minimizou os atritos e, o que é mais importante, generalizou uma percepção que foi se tornando cada vez mais forte de que os Estados teriam de abrir mão de formas de acumulação política por meio da expansão territorial. Em segundo lugar, ainda de acordo com Arrighi, após o Tratado de Vestfália foram se estabelecendo normas para as disputas militares entre os Estados de forma que os conflitos não interferissem no andamento dos negócios, visto como importantes fontes de riqueza. Riqueza esta fundamental para garantir tanto os meios de subsistência como os próprios meios de guerra. Neste contexto passa a ser cada vez mais importante estabelecer o limite do território nacional, o qual, como mostra Machado no trecho a seguir tem um significado bastante distinto do de fronteira.

\footnotetext{
${ }^{7}$ Machado, 1998, pág. 41
} 
A palavra limite, de origem latina, foi criada para designar o fim daquilo que mantém coesa uma unidade territorial, ou seja, sua ligação interna. Essa conotação política foi reforçada pelo moderno conceito de Estado, onde a soberania corresponde a um processo absoluto de territorialização ${ }^{8}$.

O conceito de territorialização é usado pela autora neste caso - apesar de nem sempre - como a busca por parte de um Estado nacional de efetivar seu poder dentro de seu território. Estabelecer o limite, portanto, não significa apenas traçar as linhas que separam o interior do exterior, mas igualmente "manter coesa a unidade territorial". Significa, portanto, fazer valer a regulamentação estatal em toda a extensão de-limitada. Esta necessidade está diretamente ligada à especialização do Estado como agente político. Diante da externalização da extração de excedente por parte do âmbito estatal - o fim da extração política do excedente - o seu papel passa a ser regular o território no sentido de produzir ali os pressupostos para a acumulação propriamente econômica por parte dos capitalistas. Mas a criação destes pressupostos não significa uma subserviência absoluta do Estado nacional a estes últimos. Ao contrário, o Estado tende a promover tal regulamentação diante de sua própria necessidade de garantir a geração de riqueza abstrata no interior de seu território de forma a atingir as condições de reprodução de seu poder político. Neste sentido, a acumulação capitalista no interior do território interessa diretamente ao Estado nacional, sendo um dos mais importantes determinantes de seu processo de territorialização. Os capitais individuais, por sua vez, também precisam se territorializar. Sua territorialização se dá no sentido de que eles se integram a um território nacional específico. Integrar-se a este território é passar a ter os elementos que compõem o espaço social deste território como determinantes seus. Se entre estes elementos não estiverem os pressupostos da acumulação capitalista não é viável a territorialização. Se, por exemplo, o Estado não garantir a propriedade privada, a existência de uma moeda e normas que garantam os contratos, não estarão constituídos os pressupostos da extração econômica do excedente.

Em princípio pode parecer que os interesses do Estado e os dos capitais individuais são coincidentes, mas não é bem assim. Fundamentalmente ocorre que cada um deles tem seus próprios interesses, mas para realizá-los precisa também realizar, em parte, o interesse do outro. Porém, realizar o interesse do outro pode significar deixar de realizar uma série

\footnotetext{
${ }^{8}$ Machado, 1998, pág. 42. [grifos meus]
} 
de interesses seus. Desta forma, os capitais individuais tendem a realizar os interesses do Estado - e vice-versa - na medida em que isso realize interesses seus e que estes interesses realizados sejam mais prioritários do que aqueles que não poderão ser realizados, ou que a realização dos primeiros de alguma forma compense a não realização dos últimos, ou ainda, que não haja outra opção. Em termos de territorialização, o Estado tende a tentar compor o território nacional com elementos, normas e objetos, que garantam o seu poder. Nem todos os elementos que interessariam ao poder estatal interessam igualmente aos capitais ali instalados. Por sua vez, estes capitais esperam poder se integrar a um território no qual exista um conjunto de normas que lhes possibilite a reprodução mais livre possível de mediações não econômicas. O problema é que muitas dessas mediações interessam ao Estado.

O que temos, portanto, é uma situação conflituosa na qual a coincidência dos interesses dos capitais e do Estado se dá mais por exclusão que por inclusão, mais por necessidade que por identidade. Cada um dos lados tende a aceitar necessidades do outro, a priori externas à sua própria lógica, apenas na medida em que isso seja inevitável para garantir sua própria reprodução. Cria-se uma constante tensão entre ambos de forma que a união seja sempre precária, sempre passageira. Esta precariedade é determinada por dois elementos diretamente interligados, o desenvolvimento contraditório do capital em geral e a disjunção espacial à qual nos referimos acima, que por sua vez possibilita a migração da riqueza entre os territórios nacionais. Promovendo uma interpretação da descrição dos quatro ciclos sistêmicos de acumulação, feita por Arrighi (1996), podemos visualizar este movimento. Arrighi, seguindo Braudel, vê a história do capitalismo distribuída em quatro ciclos sistêmicos de acumulação. Para identificar a lógica e as fases destes ciclos o autor se refere ao esquema D-M-D’ de Marx. Em princípio a referência pode parecer um tanto, digamos, livre demais e talvez em certos pontos seja realmente. Mas de qualquer maneira, como veremos a seguir, há analogias bastante interessantes.

Marx utiliza o dito esquema para tratar do processo produtivo no qual o dinheiro se transforma em mercadoria (meios de produção, matérias primas e força de trabalho) para posteriormente transformar-se novamente em dinheiro, agora ampliado. Neste percurso, o capital $^{9}$ em sua forma mais representativa de riqueza abstrata, isto é, na forma do dinheiro, tem de se materializar em mercadorias específicas e num processo de produção também específico - elementos, portanto, nada abstratos - para posteriormente voltar à sua forma

\footnotetext{
${ }^{9}$ Neste momento da apresentação Marx fala de capital, não diferenciando o capital em geral dos capitais individuais.
} 
abstrata e, agora, ampliada. Isso significa, em primeiro lugar, que a ampliação do capital enquanto riqueza abstrata nunca é autônoma em relação à materialidade e às formas concretas de sua manifestação - esta ou aquela mercadoria, este ou aquele processo produtivo. Mas, em segundo lugar, isso nos mostra que para se realizar como o que é o capital não pode ficar preso a estas mesmas formas, tendo de se incorporar nelas apenas na medida do estritamente necessário.

Estes elementos que caracterizam formas concretas de manifestação do capital - os meios de produção utilizados, os trabalhadores contratados, os consumidores que comprarão estas mercadorias ... - são, a priori, exteriores à lógica do capital. Sem dúvida que há uma tendência em se reduzir estes elementos a esta lógica por meio de sua internalização no processo de reprodução da riqueza abstrata. No entanto, considerando a diferenciação proposta por Holloway (2003) entre fetichismo e fetichização, segundo a qual o fetichismo da mercadoria não é algo que se reproduz automaticamente, precisando ser constantemente reposto (o que seria a fetichização), esta redução nunca pode ser considerada como absoluta e sempre apresenta um caráter conflituoso. Qualquer trabalhador, por exemplo, continua sendo um ser humano mesmo se reproduzindo por meio da venda de sua força de trabalho. Enquanto tal, ele tem necessidades irredutíveis que tendem a se pôr como fins que lhe são próprios - suas expectativas, suas ansiedades, suas deficiências - em sua relação com o processo de valorização do capital. Há condições histórico-geográficas nas quais o capital encontra estes fins exteriores a ele como seus limites externos, ou, para ser mais preciso, condições da abstração da riqueza ficam limitadas.

Tais condições tendem a mudar porque o capital é, por definição, contraditório e, por isso, é movimento. Movimento no tempo. Movimento no espaço. Em relação aos trabalhadores, por exemplo, havendo a tendência de que o avanço tecnológico leve a uma diminuição do número de empregos e, com isso, ao aumento do exército industrial de reserva, a elevação da concorrência entre os trabalhadores por mais empregos, ao mesmo tempo em que é um produto do próprio movimento do capital, propicia uma intensificação da abstração. Ou seja, os trabalhadores têm de aceitar que menos fins próprios à exterioridade que eles representam funcionarão como limites à reprodução do capital. Esta mesma intensificação da lógica do capital pode se dar por meio do possível e necessário deslocamento dos capitais individuais de lugares mais industrializados para outros menos 
industrializados, nos quais o exército industrial de reserva ainda se encontra como população não incorporada à proletarização.

Esta interpretação do esquema de Marx não se limita ao processo produtivo por ele descrito, mas procura apreender a problemática da necessária transformação do capital ao longo do processo de valorização e os conflitos que esta transformação envolve para tentar vislumbrar como estes conflitos podem variar ao considerarmos a dimensão histórica e a geográfica. Arrighi faz algo próximo a isso, mas seu foco no caso dos ciclos sistêmicos de acumulação não se limita aos conflitos advindos das necessárias transformações do capital no processo produtivo. Ao invés disso, ele apresenta um movimento de transformação num prazo e num sentido mais estendidos. São quatro ciclos, o primeiro dominado pelas cidades-estado do norte da Itália, entre os séculos XV e XVII, o segundo, o ciclo holandês, entre o século XVI e meados do XVIII, o terceiro é o britânico, que durou de meados do XVIII a início do XX e o último o norte-americano que vai do final do XIX até a atualidade. Cada ciclo é composto por um primeiro período - representado por M-D caracterizado por uma expansão material, ou seja, os representantes do capital investem o dinheiro disponível prioritariamente na produção e no comércio. Depois vem um segundo ciclo no qual há um período de expansão financeira - D-M' - que representa ao mesmo tempo o ápice e o fim do ciclo. Neste período os representantes do capital tendem a buscar formas mais flexíveis de valorização, caracterizadas pelas atividades puramente financeiras.

Além do papel dos capitalistas cada um dos ciclos é caracterizado pela ascensão e queda de uma potência hegemônica. As relações entre as potências e os representantes do capital são analisadas por meio do par capitalismo e territorialismo. A lógica capitalista de poder seria aquela ligada ao princípio regulador fundamental do capitalismo, investir dinheiro para produzir mais dinheiro. A lógica territorialista estaria ligada à pretensão sempre referida a representantes estatais - de aumentar o domínio territorial, direta ou indiretamente. Mas da mesma maneira que os outros autores aqui considerados, Arrighi vê as relações entre Estado e capital como contraditórias e, ao mesmo tempo, interdependentes de modo que estas lógicas de poder são tratadas uma em relação à outra. Para expressar esta relação tal autor utiliza um par de fórmulas. O predomínio da lógica territorialista sobre a capitalista poderia ser representado pela fórmula T-D-T', enquanto o predomínio da lógica capitalista sobre a territorialista se expressaria na fórmula D-T-D'. Ou seja, enquanto no primeiro caso a prioridade era usar o território já dominado para 
gerar riqueza para aumentar os domínios territoriais, na segunda a riqueza deve ser usada para aumentar os domínios territoriais na medida em que isso leva ao aumento da riqueza.

No tratamento dos quatro ciclos, Arrighi destaca muitos elementos diferentes, desde as formas de administração estatal às de arbitragem financeira, passando por formas de organizar a produção e o comércio. Para identificar um sentido geral em todo este conjunto pode-se dizer que há uma crescente internalização da lógica capitalista em todos estes processos, isto é, todos eles vão sendo crescentemente mediados pelas necessidades de reprodução da riqueza abstrata. Porém, esta tendência não é homogênea, ao contrário é marcada por um movimento de continuidades e descontinuidades. É a identificação deste movimento que pode nos ajudar no esclarecimento sobre os processos de territorialização dos quais começamos a tratar acima. Vejamos, portanto, sinteticamente como ele se dá.

No primeiro ciclo Veneza e Gênova tinham destaque entre as cidades da Itália setentrional. Em Veneza o Estado era forte e centralizador, mas segundo Arrighi é o melhor exemplo de um Estado absolutamente subserviente aos interesses dos capitalistas. Esta sua característica fazia do Estado veneziano apenas um instrumento de proteção para o comércio da cidade não envolvendo em sua lógica de poder qualquer pretensão expansionista em termos de domínio territorial. Entre aquelas fórmulas T-D-T' e D-T-D' o T nem era considerado. Essa ausência de uma lógica territorialista limitou o crescimento do capitalismo veneziano, o que é um exemplo interessante de como a expansão capitalista só pode se dar por meio de uma aliança com elementos não capitalistas.

Por sua vez, Gênova tinha um Estado fraco, sem capacidade de promover uma auto-proteção dos interesses comerciais da cidade. Esta fraqueza tornou necessária a aliança entre os capitalistas genoveses e as potências ibéricas, principalmente a Espanha, como uma forma de contratar serviços de proteção. A característica fundamentalmente dinástica da organização do poder na Espanha tornava-a um ótimo exemplo da prioridade à lógica territorialista. Ou seja, a prioridade da coroa espanhola era expandir seus domínios territoriais. Da aliança entre genoveses capitalistas e espanhóis territorialistas produziu-se a primeira grande expansão que faria do capitalismo um sistema mundial. A fase áurea dessa expansão - século XVI - foi marcada por uma forte expansão material, a qual ampliou as rotas comerciais e promoveu a colonização das Américas.

Mas é interessante notar que esta aliança não se dava entre um poder unificado em Gênova e outro na Espanha, mas entre os comerciantes e banqueiros genoveses dispersos 
em uma rede de cidades que iam para além da região do norte da Itália e o governo espanhol, este sim unificado. Havia, portanto, de um lado uma organização territorialmente dispersa de agentes capitalistas e, de outro, um agente estatal territorialmente unificado. Sobre o primeiro grupo Arrighi destaca o seguinte:

Tal como nos sistemas de governo baseados nos laços de parentesco, estudados pelos antropólogos, a rede de intermediação comercial e financeira controlada pela elite mercantil genovesa ocupava os lugares, mas não era definida pelos lugares que ocupava. Mercados como os de Antuérpia e Sevilha, bem como as feiras móveis de Bisenzone, eram tão cruciais quanto a própria Gênova para a organização do espaço de fluxos através do qual a dispersa comunidade genovesa de banqueiros mercantis controlava o sistema europeu de pagamentos interestatais. Mas nenhum desses lugares - inclusive Gênova - definia, por si só, o sistema de acumulação genovê ${ }^{10}$.

Se nenhum dos lugares pelos quais a rede dos genoveses se distribuía definia por si só seu sistema de acumulação, o que o definia? $\mathrm{O}$ fato de que, devido à sua condição de comerciantes e banqueiros, a reprodução destes agentes era intermediada pela lógica da riqueza abstrata, isto é, investir dinheiro para gerar mais dinheiro. Nos termos desta lógica, enquanto a melhor opção entre as possíveis era uma aliança com os espanhóis, o capital fluía por aquela organização territorial dispersa até se integrar à territorialidade do governo espanhol. Enquanto esta última era definida de acordo com interesses não propriamente capitalistas aquela outra o era. No entanto, naquela situação histórico-geográfica específica a aliança pôde se dar. Quando esta situação mudou - por um lado porque o arranjo de poder na Europa criava outras possibilidades de investimento e por outro porque os espanhóis insistiam em levar adiante sua lógica territorialista além de um ponto aceitável a aliança dos capitais genoveses com o governo da Espanha entrou em decadência, já que naquela rede de comerciantes e de banqueiros, sem que houvesse uma decisão centralizada, mas simplesmente pelo fato de que os agentes que a constituem devem seguir a lógica de reprodução da riqueza abstrata, o dinheiro começou a migrar para outras localidades.

A partir deste momento Arrighi vai reconstituindo as migrações do capital financeiro para a Holanda, posteriormente para a Inglaterra e mais tarde para os Estados Unidos. Estas migrações sempre estiveram ligadas à forma como foram sendo criadas e

\footnotetext{
${ }^{10}$ Arrighi, 1996, pág. 83. [grifos meus]
} 
destruídas as alianças entre as lógicas capitalista e territorialista. Reconstituir todos os detalhes que demonstram este movimento seria algo inviável no corpo do presente trabalho, desta forma, opto por resumir seu sentido geral. O que vemos é uma relação constantemente contraditória entre duas lógicas de poder uma territorialista ligada ao Estado e outra capitalista ligada aos detentores do dinheiro. Quando há a possibilidade de ambas se unirem há uma expansão material, quando esta união não é possível ou interessante para os capitalistas dá-se uma fuga de capitais e, portanto, uma expansão financeira. Percebe-se, portanto, que há uma sucessão de momentos nos quais os capitalistas deixam-se controlar pelo Estado - porque esta é a melhor opção para garantir sua reprodução - e outros em que eles escapam ao controle estatal, em parte por necessidade de fazê-lo. Vejamos como este movimento pode ser reconhecido nas lógicas de territorialização.

O território nacional é um espaço politicamente delimitado que se pretende, a priori, homogêneo. Porém, internamente, ele é fragmentado em espaços privados. Pode-se identificar, portanto, uma cisão interna ao território enquanto espaço produzido no contexto da separação entre o econômico e o político. O que o Estado procura fazer é coordenar este conjunto de espaços apropriados privadamente no sentido de garantir a reprodução social. Estão envolvidos nesta reprodução social o poder econômico dos capitais individuais, o poder do próprio Estado e as lógicas de poder que escapam tanto a um como a outro, principalmente, a lógica da alienação do capital em geral. Esta última, como vimos se põe por meio da eliminação de separações que o espaço - tanto como distância como em termos de espaço social - impõe. Como se produz a eliminação de tais separações? Por meio da ação dos próprios capitais individuais e do Estado, os quais ao se encontrarem em determinadas situações nas quais têm de se reproduzir acabam por realizar as condições para a efetivação da alienação própria do capital. Veja-se, sobre isso, o seguinte trecho de Lefebvre;

O capitalismo e o neocapitalismo produziram o espaço abstrato que contém o "mundo da mercadoria", sua "lógica" e suas estratégias à escala mundial, ao mesmo tempo em que o poder do dinheiro e do Estado político. Este espaço abstrato apóia-se sobre as enormes redes dos bancos, dos centros dos negócios, das grandes unidades de produção. E também sobre o espaço das auto-estradas, dos aeroportos, das redes de informação. Neste espaço, a cidade, berço da acumulação, 
lugar da riqueza, sujeito da história, centro do espaço histórico, explodiu ${ }^{11}$.

A produção destas redes motivada pelas necessidades dos agentes envolvidos tanto o Estado como os capitais individuais - acaba por levar a um resultado não previsto, a explosão da cidade. Se considerarmos a explosão da cidade da mesma forma como foi feito no capítulo anterior, como a produção da simultaneidade concreta, esta simultaneidade estaria explodida por meio das redes que perpassam os territórios. Vale a pena então dar uma olhada no seguinte trecho de Machado;

\begin{abstract}
É possível argumentar, do ponto de vista geográfico, que a utilização das redes como instrumento heurístico se deve à representação da ação à distância, que se associa, assim, à extensão territorial. Nessa representação, o território não é um elemento neutro, e sua condição material não deve ser oposta à presumida condição imaterial da ação à distância.
\end{abstract}

Isso se deve não só ao fato de que as redes ajudam a compreender a relação entre território e ação à distância, mas porque elas esclarecem igualmente o próprio conceito de território, se aceitarmos a noção sugerida por Raffestin, segundo a qual as redes constituem o meio de produzir o território ${ }^{12}$.

Recuperando a discussão iniciada há algumas páginas atrás temos um clareamento maior sobre duas formas diferentes de territorialização. Por lado, a territorialização como tentativa do Estado nacional de garantir o estabelecimento de normas em toda uma área sobre seu domínio de forma a tentar direcionar as ações realizadas dentro desta área. É importante destacar que esta regulamentação pode envolver os interesses dos capitais individuais e os do Estado - acumulação originária e acumulação estatista. Por outro lado, há um processo de constituição de redes territoriais dirigido muitas vezes de forma fragmentada e sem a pretensão de estabelecer o domínio sobre uma área, mas apenas garantir a reprodução do próprio poder econômico. Entre estas duas formas de territorialização penso que podemos identificar uma constante tensão, uma constante contradição. É o que fica subentendido, por exemplo, no seguinte trecho de Novy;

\footnotetext{
${ }^{11}$ Lefebvre, Produção do espaço, pág. 39 capítulo 1

${ }^{12}$ Machado, 1998, pág. 47.
} 
Por um lado existe um espaço de poder, mas ele é determinado por forças estruturais não imediatamente reconheciveis, que primeiro precisam ser trazidas à superfície. No âmbito do presente trabalho falo de poder sobre o espaço quando me refiro às forças que criam, constroem, reforçam, desvalorizam e destroem os espaços de poder. Trata-se de um poder estrutural.

Ao passo que a criação de espaços de poder é determinada pelo empenho em criar um espaço no qual se possa agir, o poder sobre o espaço é uma forma estrutural que solapa sempre de novo esse empenho da territorialização ${ }^{13}$.

Os espaços de poder, no caso, poderiam ser identificados com a tentativa do Estado - mais, ou menos, aliado aos capitais individuais - de garantir o controle sobre as ações numa determinada área. É o que fica mais claro no seguinte trecho;

A criação de um espaço de poder representa a tentativa de atores sociais de delimitar um determinado espaço, para que no seu âmbito a ação possa transcorrer de acordo com regras determinadas. Delimita-se um espaço para que a ação possa ter eficácia nele ${ }^{14}$.

Esta tentativa, no entanto, é constantemente, solapada pela constituição do poder sobre o espaço, um poder estrutural que tem a ver mais com os elementos que constituem o espaço, entre os quais, sem dúvida, podemos incluir as redes. Mas esta idéia só ganha toda sua concretude quando constatamos que há um desencontro entre os espaços de poder e o poder sobre o espaço, um desencontro que já foi apontado anteriormente, se bem que num outro contexto, mas que agora também ganha mais concretude com a referência às redes territoriais. É o desencontro entre o nacional e o transnacional. Enquanto os espaços de poder se limitam à primeira situação, o poder sobre o espaço, justamente por ser estrutural, se encaixa na segunda. As redes territoriais extrapolam o âmbito de regulamentação de cada Estado nacional e, desta forma, o poder sobre o Espaço tende a minar a efetivação dos espaços de poder.

Como ficamos, portanto, no âmbito do sistema interestatal? Temos a superfície terrestre dividida entre espaços de poder mutuamente reconhecidos pelos respectivos

\footnotetext{
${ }^{13}$ Novy, 2002, pág. 33.

${ }^{14}$ Novy, 2002, pág. 27.
} 
Estados nacionais. As zonas de fronteiras tendem a ter limites variáveis conforme o momento histórico. De acordo com estes limites têm-se uma maior ou menor interpenetração destes espaços, não por meio dos próprios espaços de poder - territórios nacionais - os quais são mutuamente excludentes, mas por meio de redes que interligam os lugares, constituindo o poder sobre o espaço, com um componente interessante ao qual Lefebvre constantemente se refere em sua obra, um espaço homogêneo e, ao mesmo tempo, fragmentado:

Esse espaço "homogêneo e fragmentado", como se mantém? Como ele se mantém, se tem simultaneamente as duas características, formalmente incompativeis? Como esses dois atributos, não "compatíveis" do ponto de vista lógico, podem se associar e constituir um "todo" que não se desintegre e possa mesmo servir ao desdobramento das estratégias?

[...] A resposta não se encontra no espaço como tal enquanto coisa ou conjunto de coisas, fatos ou encadeamento de fatos, "meio" ou "meio ambiente". Procurar nesse sentido é retornar à tese do espaço neutro, anterior ou exterior à prática social, portanto mental e fetichizada (objetivada) por essa razão. Apenas um ato pode conter e manter juntos fragmentos numa totalidade homogênea. Apenas uma ação pode reter o que se dispersa: como a mão fechada segura a areia $^{15}$.

É interessante associar esta pergunta a uma outra, que vai no mesmo sentido, feita por Arrighi. Após expor as características principais da expansão capitalista liderada pelas potências ocidentais, o autor propõe a questão:

Por que [esse expansionismo] prosseguiu, sem ser impedido pela queda de um Estado ocidental após o outro, até a quase totalidade da superfície terrestre ter sido conquista por povos de ascendência européia? ${ }^{16}$.

Tanto Lefebvre como Arrighi identificam uma condição crítica, uma cisão que promove uma explosão de fragmentos no espaço e de sucessivas crises no tempo. Conforme se entenda esta condição crítica pode-se produzir um conhecimento que apenas a reflita ao ser, igualmente, fragmentado e apenas reprodutor dos estilhaços. Mas não

\footnotetext{
${ }^{15}$ Lefebvre, A produção do espaço.

${ }^{16}$ Arrighi, 1996, pág. 36.
} 
parece isso que indicam estes autores. Ao invés de aceitarem a crise por ela mesma, buscam decifrar-lhe o sentido, aquilo que perpassa os fragmentos e revela seu conjunto como estratégia. É tratando destes fragmentos e daquilo que os une que pretendo finalizar este trabalho nas duas próximas seções.

\section{3 - A ante-sala da crise}

Tentar reconstituir a crise contemporânea buscando suas origens é um caminho importante, mas não é o que desenvolverei a seguir. Mais importante para este trabalho é considerar que a crise é a explosão das contradições e, desta forma, pode ser reveladora delas. Para ir ao núcleo da crise, portanto, pode ser preciso se aproximar daquilo que ela explodiu. Neste sentido comecemos com o seguinte trecho de Oliveira;

O rompimento do círculo perfeito do Estado-providência, em termos keynesianos, é devido, em primeira instância, à internacionalização produtiva e financeira da economia capitalista. A regulação keynesiana funcionou enquanto a reprodução do capital, os aumentos de produtividade, a elevação do salário real, se circunscreveram aos limites - relativos, por certo -, da territorialização nacional dos processos de interação daqueles componentes da renda e do produto. Deve-se assinalar, desde logo, que aquela circularidade foi possível graças ao padrão de financiamento público do Welfare State, um dos fatores, entre outros, aliás, que levaram à crescente internacionalização. Ultrapassados certos limites, a internacionalização produtiva $e$ financeira dissolveu relativamente a circularidade dos processos de retro-alimentação. Pois des-territorializaram-se o investimento, e a renda, mas o padrão do financiamento público do Welfare State não pôde - nem pode, até agora-desterritorializar-se ${ }^{17}$.

Antes de retornar ao problema da desterritorialização, vejamos algo acerca do círculo-perfeito de que fala o autor, afinal de contas é justamente ali que estavam instaladas as contradições fundamentais que posteriormente explodiriam em crise. Sem pôr em questão a sua efetiva perfeição, entendamos este círculo perfeito como um arranjo precário e passageiro, mas ainda assim um arranjo - entre os elementos que constituem a

\footnotetext{
${ }^{17}$ Oliveira, 1998, pág. 26.
} 
condição crítica que é o capitalismo. Um arranjo que produziu por certo tempo sua retroalimentação de modo a propiciar uma expansão material que foi entendida por alguns como a era de ouro do capitalismo (Hobsbawm, 1996). Para Harvey (1992) esta retroalimentação foi possível no contexto de uma aliança entre os capitalistas individuais, o Estado e a classe trabalhadora. Vejamos isso mais de perto.

As crises das décadas de 1920 e 1930 tinham demonstrado claramente os riscos para os capitalistas de uma opção pela busca do lucro desgarrada de processos produtivos reais, aliás, não apenas os riscos, mas principalmente a sua impossibilidade. $\mathrm{O}$ retorno a tais processos não era, no entanto, algo direto, livre de outras mudanças. Pode-se vislumbrar, neste momento, facetas interessantes da condição crítica própria da reprodução da riqueza abstrata. Após sua - até então - maior fase de expansão material sob hegemonia inglesa e a difusão dos processos industriais a todo seu núcleo orgânico, o capitalismo enquanto sistema econômico mundial encontrava-se num impasse. Era preciso dar um salto em direção a uma forma de sociedade que possibilitasse a continuidade do incremento de produtividade. As necessidades próprias da produção e realização da riqueza, até então concentradas prioritariamente no interior da fábrica a extrapolaram em direção à sociedade como um todo (Lefebvre). A reprodução, neste contexto, precisou incorporar outros elementos a priori estranhos à sua lógica. Foi necessária, da parte dos capitais individuais, a aceitação - mesmo que tendendo à redução enquanto momentos de sua reprodução - de elementos que se referiam a finalidades de outros âmbitos da sociedade: o Estado, a classe trabalhadora.

$\mathrm{Na}$ perspectiva de sua incorporação a uma sociedade de consumo em massa em gestação, os trabalhadores foram tacitamente concordando em pôr em segundo plano onde eles ainda tivessem real importância - os ideais socialistas. As perspectivas de luta contra o trabalho presentes em movimentos trabalhistas do século XIX foram dando lugar a lutas por melhores salários. Ao serem atendidos os trabalhadores tiveram, nos países centrais principalmente, da parte dos capitalistas sua recompensa na aliança. Da parte do Estado esta recompensa veio em forma de direitos num crescente Welfare State que possibilitou um forte incremento do emprego e, portanto, do crescimento econômico mas, ao mesmo tempo, inegavelmente produziu a estruturação de uma esfera pública até então inexistente (Oliveira, 1998). 
Mas longe de ser algo neutro, esta esfera pública é característica da transformação do Estado em Estado democrático. A posição estatal neste caso não pode ser vista nem como subserviente aos interesses dos capitalistas nem como progressista num sentido ingênuo. O que se dá é uma maior posição do Estado, afinal, ao contrário do que podia ser encontrado no liberalismo, a democracia consiste não numa liberdade abstrata do indivíduo mas sim na produção da regulamentação estatal sobre essa liberdade (ver Dupas, 2003). Ao âmbito estatal passam as decisões acerca dos investimentos das empresas (por meio das concessões de empréstimos e outros instrumentos), do trabalho e da vida dos trabalhadores (lazeres, moradia, planejamento familiar, cuidado com a saúde), enfim, numa tendência crescente o Estado se transforma num regulador de última instância da reprodução social. Esta é a posição do Estado no sentido de que ele se torna aquilo que o caracteriza fundamentalmente, uma mediação entre os interesses privados e o interesse geral, entre o particular e o universal como definiu Hegel.

Mas já que o Estado só existe como Estado nacional esta condição de mediação só pode se dar por meio do processo de territorialização da regulamentação estatal. Nos termos de Novy, que nos ajudam a explicar este processo, tem-se o Estado instalado num espaço de poder - que é seu próprio território nacional -, mas tendo que fazer com que seu poder se faça valer como poder sobre o espaço. Revela-se uma busca de comando das ações de modo que cada ação privada seja direcionada no sentido da realização do interesse público - próprio da esfera pública. A organização do território nacional se aproxima da idéia de zona no sentido de que qualquer territorialização privada promovida dentro dos limites deste território tem que aceitar este direcionamento, este elemento estatista.

No caso dos países centrais - cada um com sua particularidade evidentemente - dáse uma forma de territorialização segundo a qual os investimentos privados encontram dentro daqueles territórios os elementos que irão propiciar o salto para um capitalismo de massa no qual a maioria da população é inserida como força de trabalho e como mercado de consumo. Como força de trabalho de acordo com aquele acordo - estabelecido via grandes sindicatos - em se passar da luta contra o trabalho à luta pelo salário. Como mercado consumidor com o poder de consumo que passou a lhe ser próprio devido aos aumentos salariais, à ampliação do crédito (à qual vou me referir mais profundamente no próximo item) e ao papel do Estado de Bem-estar. Ainda nestes países, o uso do fundo 
público como financiador para o desenvolvimento tecnológico os tornou territórios de forte inovação nesta área.

Quanto ao Brasil, que evidentemente é de nosso particular interesse, o período fordista-keynesiano teve como equivalente local o nacional-desenvolvimentismo. Já neste rótulo se podem reconhecer os parâmetros fundamentais deste modelo de reprodução. Um caráter nacional, mesmo que ambíguo, e a problemática do desenvolvimento. Ambos têm de ser vistos como mediações do que poderíamos entender como capitalismo brasileiro, vigente principalmente entre as décadas de 1930 e 1980.

A ambigüidade do caráter nacional ${ }^{18}$ à qual estou me referindo se deve, justamente, à convivência entre um papel intenso do Estado nacional como regulador da economia e a presença maciça de capitais de origem estrangeira, seja como investimentos produtivos seja como financiadores do crescimento econômico. Se por um lado, "a fronteira do território adquiriu importância, [a ponto de que] a distinção entre dentro e fora passou a formar a linha divisória decisiva" ${ }^{" 19}$, por outro isso se deu como uma forma de produzir uma territorialização comandada pelo Estado nacional com vistas a cumprir os requisitos da aliança deste Estado e da elite nacional com os capitais internacionais. Isto é, se havia um nacionalismo em relação ao comércio externo era para garantir o mercado nacional como área de atuação privilegiada para as empresas nacionais e internacionais aqui instaladas. Deste modo, a territorialização promovida pelo Estado não era incompatível com a territorialização do capital internacional no país, como o termo nacionaldesenvolvimentismo, poderia levar a crer. Mas então vejamos mais de perto os dois lados deste processo.

Do ponto de vista do capital internacional o que estava ocorrendo era a emigração de capitais excedentes dos países centrais. Segundo Brenner (2003), estes capitais foram se tornando excedentes a partir da década de 1960, pois com a forte expansão norteamericana (desde a Segunda Guerra) unida à recuperação pós-Guerra do Japão e da Europa Ocidental foi se produzindo uma saturação dos investimentos em relação à força de trabalho e ao mercado de consumo disponíveis em tais países. Esta saturação não envolve apenas um risco de superprodução. Muito antes da efetivação de uma crise deste tipo já começam a se fazer sentir os problemas da crise enquanto não realização (ao menos de parte) da riqueza produzida. Há riqueza para ser investida, porém o seu investimento não

\footnotetext{
${ }^{18}$ Ver, por exemplo, Oliveira, 1989.

${ }^{19}$ Novy, 2002, pág. 114
} 
pode gerar, naquelas condições específicas a lucratividade esperada. Harvey (1990 e 2004) denomina esta situação como sobreacumulação e identifica as diversas formas de produção do espaço utilizadas para combatê-la como rearranjos espaciais. A idéia básica deste conceito é que se pode investir o capital de determinadas maneiras - ou em determinados lugares - de forma a eliminar, minimizar ou, ao menos, postergar o problema da sobreacumulação. Um exemplo interessante é o investimento em infra-estruturas espaciais que demorem a se realizar - ou mesmo nunca se realizem - como valor. Neste caso, aquele excesso momentâneo se dissipa, permitindo a continuidade da acumulação.

$\mathrm{O}$ interessante em se perceber nestes arranjos espaciais de Harvey é que eles impedem que o capital se ponha, constituindo-se como uma forma não capitalista de acumulação. Esta possibilidade fica mais clara naquela emigração dos capitais excedentes dos países centrais para outros espaços nacionais de acumulação. Se a posição do capital ocorre como uma intermediação das condições do mercado capitalista entre a produção e a realização da riqueza e se tais condições só se tornam efetivamente uma imposição para cada capitalista individual na medida em que ele é exposto a elas por meio da eliminação de barreiras espaciais, basta que se re-produzam tais barreiras para evitar - ou postergar - a posição do capital. Neste sentido, enquanto nos países centrais as condições de lucratividade eram declinantes devido à exposição dos capitais individuais às relações de mercado, em países como o Brasil estas condições eram privilegiadas.

Assim o eram porque estavam sendo politicamente produzidas no contexto do que Fiori (2003) denominou de um espaço nacional de acumulação. Este espaço nacional produz o que poderíamos entender como condições de mercado especificamente nacionais como intermediação entre a produção e realização da riqueza. É justamente o estabelecimento de limites territoriais muito claros, justamente quando fica clara a diferença entre o dentro e o fora, é que se pode produzir tal especificidade. Braudel se aproxima desta idéia com o conceito de anti-mercado, que segundo ele seria uma atitude do Estado para garantir a proteção dos grandes capitalistas - aos quais é aliado - em relação ao mercado. É interessante notar que para este autor esta união é, justamente, o capitalismo - como um contraponto à economia de mercado. Mesmo não trabalhando com o conceito de capital, Braudel identifica a necessidade de lógicas extra-econômicas no interior do capitalismo. Acumulação política para Fiori, anti-mercado para Braudel, a situação que se encontrava no Brasil até a década de 1980 era de proteção das empresas instaladas no interior do território nacional em relação ao que se dava fora dele. 
Esta forma não capitalista de acumulação aparece em ambos os autores, assim como em outros, como uma união dos interesses do capital internacional e do Estado nacional. Neste sentido, se do ponto de vista dos capitalistas estrangeiros a territorialização de seus investimentos no Brasil significava o acesso a condições privilegiadas de lucro, para o Estado brasileiro significava a reprodução das estruturas de poder de classe no país. Segundo Fiori (2003), desde a crise da Primeira Guerra Mundial o Estado brasileiro passou a ser o instrumento fundamental para as elites de diferentes regiões e setores da economia fazerem a manutenção de seus arranjos de poder sobre a produção da riqueza no interior do território, sempre no sentido de adiar a distribuição da terra e da renda. Inicialmente esta função social pode ser verificada nas políticas de proteção às crises da cafeicultura e, posteriormente, foi se efetivando em todo seu potencial na constituição do desenvolvimentismo. Este último passo pode ser entendido claramente com a idéia posta por Fiori de que a busca pelo desenvolvimento no Brasil se tornou uma fuga para frente. Ou seja, diante de sucessivas situações críticas que punham a necessidade de uma mudança estrutural na sociedade brasileira, no Estado - aliado ao capital internacional - se encontrava a possibilidade do crescimento econômico como alternativa à distribuição. É claro que nestes termos a aliança com os capitais internacionais foi se transformando conforme as necessidades da reprodução do poder econômico e político. Na década de 1950 ela se materializou no populismo, mais tarde na ditadura militar, dentro da qual gerou-se a falência do próprio modelo devido ao intenso endividamento da década de 1970

Mas o interessante de percebermos é que o processo de territorialização responsável pela constituição deste espaço nacional de acumulação foi marcado pela territorialização dos capitais individuais num espaço de poder que tinha como norma geral a reprodução do poder de classe do interior do território nacional. Mesmo sendo um modelo de desenvolvimento conservador, posto que crescia para manter as estruturas arcaicas de dominação, tinha um componente político dentro do qual os conflitos surgiram e só politicamente foram controlados. Neste sentido, a lógica de poder do Estado nacional se fazia presente num território que tendia a se aproximar do modelo de zona. É nesta forma de territorialização que podemos vislumbrar o círculo-perfeito ao qual se referia Oliveira. Se nela estão presentes interesses do Estado e dos capitais individuais, mas destes últimos em produzir e re-produzir as barreiras à posição capital, entendo que poderíamos identificar nesta acumulação política um misto daquilo que foi definido no item como acumulação estatista e originária. O que caracteriza tanto uma como outra é a que a mediação entre a produção e a realização da riqueza não é propriamente, ou não puramente 
(nem tendendo a ser), o capital. Dá-se algo como o que Oliveira destaca no seguinte trecho, no qual ele não trata a acumulação nestes termos, apesar de estar se referindo a uma forma não capitalista de acumulação, o antivalor que

\begin{abstract}
A rigor, trata-se de uma relação ad hoc entre o fundo público e cada capital em particular. Essa relação ad hoc leva o fundo público a comportar-se como um anticapital num sentido muito importante: essa contradição entre um fundo público que não é valor e sua função de sustentação do capital destrói o caráter auto-reflexivo do valor, central na constituição do sistema capitalista enquanto sistema de valorização do valor. $O$ valor não somente enquanto categoria central, mas práxis do sistema, não pode, agora, reportar-se apenas a si mesmo: ele tem que necessariamente reportar-se a outros componentes $[\ldots]^{20}$
\end{abstract}

Sabemos que este "territorialismo integrado" do desenvolvimentismo brasileiro entra em crise na década de 1980 e por ela passaremos - mesmo que rapidamente - em seguida, mas é preciso perceber, desde já, que este círculo-perfeito brasileiro era, por um lado, ainda menos perfeito do que seu equivalente central devido à presença do capital estrangeiro e, por outro, ele era já um primeiro sinal da crise daquele. Afinal, se como aponta Oliveira nos países centrais ele só se manteve enquanto houve uma retroalimentação da produção e dos gastos, com a "internacionalização produtiva e financeira" rompeu-se o círculo.

O rompimento deste círculo, no entanto, significa mais do que o fim da retroalimentação referida. O que se rompe, também, são as formas de intermediação entre a produção e a realização da riqueza que sobre ele haviam se erguido. E o mais importante de percebermos neste momento é que se estas formas não capitalistas de intermediação da reprodução social estavam fundamentadas num processo de territorialização promovido pelo Estado nacional, uma territorialização tendendo a zonas, o que lhe caracterizava como manifestação e, ao mesmo tempo, condição de uma esfera pública, o rompimento é um rompimento do território e por meio deste rompimento é que a crise se efetiva. Afinal de contas, se por um lado, os elementos não capitalistas constitutivos daquela forma de territorialização e de reprodução serviam ao Estado e, também, aos capitalistas individuais,

\footnotetext{
${ }^{20}$ Oliveira, 1998, pág. 29.
} 
estes últimos, quando postos diante de possibilidades melhores de lucros têm de buscá-las sob pena de não se manterem no mercado diante daqueles que o fazem. Esta necessidade de buscar as melhores condições para a reprodução já ela, ela mesma, a manifestação da relação-capital. Mas conforme os capitais individuais procuram aquelas condições eles tendem a efetivar cada vez mais esta relação.

O interessante de se considerar a dimensão territorial nesta problemática é que ela nos permite entender que ao procurarem se des-territorializar, no sentido de se verem livres dos compromissos específicos de um território e de uma sociedade nacional também específicos, isto é, ao buscarem uma condição territorial mais flexível - para usar o termo de Harvey (1992) - os capitais individuais promoveram a revalorização de uma territorialização em redes em detrimento daquela em zona. Claro, é indispensável lembrar, não o fazem sozinhos. Sua ação continua se dando em conjunto com a ação estatal. Na verdade como sugere Machado no trecho a seguir é o próprio Estado que altera a regulamentação do território para tornar possível aquela outra mudança.

\section{O próprio conceito de lei territorial está sendo modificado pelos Estados. Observa-se a crescente manipulação dos limites do território sob sua jurisdição, de modo a criar territorialidades específicas, onde os regulamentos internos ao país são relaxados e modificados ${ }^{21}$.}

Ou seja, continua existindo um espaço de poder no qual o Estado busca de pôr, no entanto o poder sobre o espaço, o poder estrutural das redes mina esta busca com muito mais efetividade. Por meio desta forma de territorialização em rede é que vai se re-pondo com mais intensidade o capital como alienação, uma vez que é nas redes que se encontra, concentrada, a simultaneidade concreta à qual me referi anteriormente. Se, neste sentido, esta nova (ou renovada) tendência territorial é a condição para a crise atual, o seu resultado é o rompimento daqueles mecanismos não-econômicos de intermediação, em relação ao Estado, é a fragmentação da esfera pública diante do fortalecimento do âmbito privado. Como é o reforço da riqueza abstrata como mediação para a reprodução social, melhor seria denominar esta tendência territorial - inclusive para se evitar os riscos do termo desterritorialização - como uma territorialização abstrata.

\footnotetext{
${ }^{21}$ Machado, 1998, pág. 43.
} 


\section{4 - Crise e financeirização.}

Segundo Belluzzo, numa economia monetária da produção 22 "o dinheiro é, simultaneamente, um bem público e um instrumento de enriquecimento privado" ${ }^{23}$. É um bem público por ser medida dos preços, meio de circulação e reserva de valor. É um instrumento de enriquecimento privado, por exemplo, porque por meio do uso de dinheiro que se dá a apropriação das condições da produção - para não tratar ainda do mercado financeiro. Mas para extrairmos as consequiências da identificação deste caráter contraditório da existência do dinheiro é interessante lembrar, seguindo Germer (2000), que o dinheiro é anterior ao capitalismo, sendo posteriormente incorporado e modificado dentro desde sistema econômico.

A função pré-capitalista do dinheiro era propiciar trocas de bens entre comunidades dispersas pelo espaço. Como no interior das comunidades a tendência é que as trocas fossem mais diretas e menos numerosas, o mais comum é que o uso de dinheiro se desse, em geral, nas zonas de contato entre diferentes comunidades e, principalmente, por meio das redes de mercadores. Além disso, qualquer objeto poderia assumir o papel do dinheiro contanto que fosse socialmente reconhecido como tal. Por parte dos mercadores havia uma tendência em identificar como dinheiro objetos que eles poderiam utilizar como meio de troca em diversos lugares. Podemos dizer, portanto, que havia, nestas condições uma livre regulação - ou uma não regulação - do dinheiro e seu uso como meio de integrar as comunidades diferentes. Mas estas condições eram próprias de sociedades não capitalistas nas quais o mercado pode ser visto como mera possibilidade de trocar excedentes.

No capitalismo a produção passa a ser intermediada pela troca monetária, só ocorrendo se resultar em acúmulo de dinheiro. Em tais condições é que se põe a condição contraditória do dinheiro, posto que toda a estrutura de reprodução social passa a intermediada por ele, por causa disso, surgem oportunidades para se ganhar dinheiro lidando com dinheiro, isto é, produzindo, comprando e vendendo dinheiro - atividades de arbitragem. Neste contexto uma regulação do dinheiro passa a ser algo cada vez mais importante para preservação das condições da reprodução.

\footnotetext{
${ }^{22}$ Conceito de Keynes para identificar uma sociedade na qual a produção é movida pela possibilidade do lucro monetário.

${ }^{23}$ Belluzzo, 1997, pág. 154. Ver também Guttmann, 1998, pág. 63.
} 
A separação entre o econômico e o político faz deste último o âmbito da regulação para que a extração puramente econômica se reproduza. Considerando que o político se condensa no Estado e que o Estado (moderno) é nacional, a regulação sobre o dinheiro está diretamente ligada ao estabelecimento do sistema interestatal. Aquela condição précapitalista na qual o dinheiro tinha sua "regulamentação" dentro das próprias redes e servia como instrumento de contato nas fronteiras, passa a ser sobreposta pela territorialização dos Estados nacionais por meio do estabelecimento de seus limites e, portanto, pela tentativa de de-limitar o dinheiro como moeda nacional. Com esta delimitação centralizase no âmbito do Estado a regulação sobre dinheiro, possibilitando a definição acerca do que deve ou não ser considerado dinheiro - o estabelecimento de um dinheiro oficial assim como controlar sua produção, distribuição e destruição. Com este controle o Estado pretende garantir a regulamentação do dinheiro no sentido de assegurar que aquela sua dimensão pública seja respeitada. Esta dimensão pública do dinheiro é tão pouco neutra como qualquer outro elemento da esfera pública. Ela é perpassada pelos interesses que dominam a reprodução do poder do próprio Estado. Isso significa, simplesmente, que a moeda nacional, diferentemente do dinheiro em abstrato, tem uma dimensão política para além de sua dimensão como representante universal da riqueza abstrata.

Mas é claro que esta dimensão política da moeda não é autônoma, afinal ela só não se reduz de forma absoluta à condição de representante universal da riqueza abstrata, o que não significa que ela não continue a ter esta determinação contida nela. Afinal de contas, a moeda nacional é apenas o dinheiro oficial, ela não é o único dinheiro que existe. Por cima dela continuam a existir formas de dinheiro internacional, as quais tendem a limitar o poder da moeda nacional, posto que na troca de mercadorias entre o nacional e o internacional estas formas internacionais do dinheiro se põe como mediações necessárias à moeda nacional. Por baixo dela mantém-se, mesmo que o Estado tente coibir, formas privadas de dinheiro, algumas mais tradicionais como as trocas não monetarizadas por meio de mercadorias-padrão, outras menos, como as diversas formas de moedas emitidas por bancos e empresas privadas.

Durante a vigência do que se convencionou chamar de padrão-ouro, principalmente sob a hegemonia britânica do século XIX e começo do XX, pode-se dizer que houve uma tendência de convergência das diferentes formas de dinheiro em torno do ouro como medida padrão. Este processo foi possível graças ao papel do Banco da Inglaterra como intermediador de última instância, porém, o alcance desta centralização foi limitado e 
grande parte dos países do mundo seguiam o padrão ouro um tanto à distância, ora se aproximando mais da conversibilidade de sua moeda nacional em relação ao ouro, ora dela se afastando.

Até a Primeira Guerra Mundial o Brasil tinha na moeda inglesa e no ouro mediações quase diretas de sua economia. Por ter uma economia fundada na exportação agrícola que permitia a importação de bens diversos, os brasileiros conheciam uma pressão muito forte do dinheiro estrangeiro sobre o nacional. Pode-se entender que a territorialização do Estado nacional é bastante limitada, o que pode ser verificado, por exemplo, no par economia agro-exportadora / território em arquipélago, segundo o qual as relações econômicas se davam de forma pouco mediada pelo conjunto do território nacional em termos de zona, tendendo a se articular em redes que ligavam as áreas produtoras aos centros compradores estrangeiros. Nestes termos, o caminho do dinheiro, seguindo esta lógica de rede, era um produto da frouxidão do território nacional e, ao mesmo tempo, um elemento que tendia a mantê-la.

Segundo o que já vimos, após a Primeira Guerra as sucessivas crises da economia cafeeira põe em risco as estruturas de poder das elites locais, fazendo com que o Estado brasileiro comece a atuar de forma mais incisiva na gestão dos problemas econômicos nacionais, numa espécie de proto-desenvolvimentismo. Em relação à moeda, de acordo com Oliveira (1989), neste momento o Estado passa a substituir o que antes se podia entender como uma intermediação externa do dinheiro - fundada na moeda externa - por uma intermediação interna. Esta internalização da intermediação financeira se dá por meio do endividamento estatal e tem como característica fundamental a agregação de um importante fator político à gestão da moeda. Ou seja, é justamente neste momento que a moeda nacional passa a ter reforçado o seu componente público, deixando de ser simplesmente a medida da riqueza abstrata ao passar a incluir dentro de si os projetos de um Estado que se punha como tal ao atender às necessidades das elites locais de manterem suas formas de dominação. Passam a compor a moeda, portanto, componentes políticos ligados àqueles sentidos de acumulação estatista e originária aos quais me referi. Isso se revela para Fiori, da seguinte maneira:

O desatrelamento da moeda brasileira de qualquer padrão hegemônico internacional. Com o fim do padrão ouro que, em sua falência, acompanha os estertores da hegemonia inglesa, nossa moeda adquire uma autonomia, preservada de fato até os anos 80, que delegará ao 
Estado a função inédita de arbitrar discricionariamente sobre o valor do dinheiro no mercado interno.

$[\ldots]$

Transferido para o Estado o poder de árbitro sobre o dinheiro, para ele também se transferia o poder de definir as margens de rentabilidade esperada e de distribuir a massa de lucros, entre os vários setores e capitais, segundo uma lógica que se afasta do mercado internacional e se enraíza, cada vez mais, no plano puro e simples do poder $^{24}$.

Mas é preciso se ressaltar que esta nova forma de gestão da moeda não é uma autonomização absoluta dela em relação ao dinheiro internacional e sim apenas uma mediação promovida pelo Estado entre o nacional e o internacional. Desta forma, a territorialização que se produz segue aquele caráter ambíguo já apontado. E, por isso, entendê-la requer sempre a referência ao âmbito externo. Da mesma forma como já fiz no item anterior acerca dos investimentos em geral é preciso explicitar a relação entre a gestão da keynesiana da moeda no plano internacional e sua gestão desenvolvimentista no nacional.

Após a Primeira Guerra Mundial o padrão ouro foi sendo mantido de forma precária e sem resultar na tendência de conversão que anteriormente se dava, manteve-se um período de indecisão que coincidiu com a crise de 1929, que é também a crise do liberalismo. Em seguida, a aliança em torno do keynesianismo deu início, a partir das mudanças implementadas já na administração Roosevelt nos Estados Unidos, à produção da moeda não mais segundo o padrão moeda-mercadoria (como era o caso do padrão ouro) mas por meio do padrão da moeda de crédito. Esta passagem significa uma grande flexibilização da emissão de moeda no sentido do rompimento com seu limite metálico (Guttmann, 1998). Passa a ser possível tanto aos bancos centrais como aos bancos privados a "criação" de moeda por meio da concessão de crédito.

O mecanismo é simples e já apresenta sua forma mais simples na emissão de cheques. Quando o cliente de um banco emite um cheque, este está sendo usado como dinheiro, mas, ao mesmo tempo, o dinheiro a ele correspondente está no banco. A priori, se imagina que o cheque será descontado e que, portanto, o dinheiro deve ficar esperando por

\footnotetext{
${ }^{24}$ Fiori, 2003, pág. 125.
} 
ele lá no banco. No entanto, o cheque pode demorar a ser trocado e pode passar de uma pessoa para outra, ainda usado como dinheiro. Enquanto o cheque e o dinheiro a ele correspondente continuarem seguindo caminhos paralelos o dinheiro terá se multiplicado. Esta mesma lógica pode ser utilizada para entendermos as várias formas de crédito que podem "produzir" dinheiro. Tais formas se expandiram enormemente, em particular no pós-guerra, e tal expansão produziu um forte aumento do poder de compra aumentando a demanda privada e pública e, desta forma, produzindo a maior expansão material que já se conheceu no capitalismo. Como destaca Guttmann;

A administração da moeda de crédito pelas autoridades monetárias do Estado originou, efetivamente, um sistema bancário capaz de financiar, de modo contínuo, os gastos dos tomadores de empréstimo, acima de seus próprios recursos, ao mesmo tempo em que sustentava estes empréstimos por meio de injeções automáticas de liquidez. Essa monetarização da dívida foi um dos pilares institucionais da expansão sem precedentes dos anos 50 e 60. Ela permitiu financiar os déficits orçamentários crescentes do Estado previdenciário e, ao mesmo tempo, os investimentos necessários em tecnologia de produção de tipo fordista [...] Diversos mecanismos de regulação, incluindo controles seletivos de crédito e subvenções estatais para canais de crédito de interesse social orientaram o crédito bancário para o financiamento da expansão da capacidade produtiva da indústria, ou para um rápido aumento da capacidade de despes de seus clientes ${ }^{25}$.

A expansão do crédito propiciou um forte crescimento nos países centrais numa situação em que o sistema financeiro estava regulado em prol do desenvolvimento econômico. Esta condição, no entanto, extrapolou estes países de modo que se o Estado brasileiro já tinha começado a se pôr como mediação entre o dinheiro internacional e a moeda nacional por meio do endividamento num período em que o crédito nem era lá tão disponível e elástico posto que seguia os limites do padrão ouro (década de 1920), com a produção da moeda de crédito esta opção será intensificada, dando origem ao nacionaldesenvolvimentismo. Com crédito disponível o Estado brasileiro pode promover as bases de sua territorialização, definindo o valor de sua própria moeda para assim construir as infra-estruturas territoriais e tudo o mais que foi necessário para levar adiante o processo

\footnotetext{
${ }^{25}$ Guttmann, 1998. pág. 65.
} 
ainda inacabado - e agora bastante alterado - de integração do território nacional. Portanto, a ambigüidade do caráter nacional deste territorialismo brasileiro se mostra ainda mais clara quando se verifica a fonte de seu financiamento.

Mas há aí um detalhe importante. Se o desenvolvimentismo brasileiro já se punha como um primeiro sinal da crise do keynesianismo, como um indício do futuro rompimento do círculo-perfeito de Oliveira, no campo financeiro este elemento se reafirma. Afinal algo há que se esclarecer: as políticas de desregulamentação da moeda em direção à produção da moeda de crédito não eram nacionais? Como neste caso, o Estado brasileiro teve acesso a um amplo aumento de crédito?

Guttmann (1998) e Belluzzo (1997) demonstram que esta desregulamentação que, a priori, deveria ser mantida dentro dos limites nacionais acabou os extrapolando. Isso se deu pelo forte aumento de moeda emitida pelos bancos através da criação de diversas formas de crédito. O que estava se dando era um desequilíbrio entre a função pública e a privada do dinheiro. Isto desembocou numa situação crítica que tornava a insolvência um constante risco, posto que a ligação entre a produção de dinheiro e a de mercadorias ficava cada vez mais tênue. Diante desta situação os bancos passaram a negociar internacionalmente suas dívidas e seus créditos no que ficou conhecido como mercado de eurodólares (pois um dos principais instrumentos foi a possibilidade de bancos negociarem dólares fora do território norte-americano). Foi por meio destes mercados que, principalmente na década de 1970, muito capital chegou ao Brasil.

Este processo foi fundamental para o desenvolvimentismo brasileiro e, ao mesmo tempo um primeiro índice da crise na medida em que estes mercados de eurodólares passaram a constituir, justamente, redes de fluxo financeiro que tendiam a fragmentar o poder de territorialização dos Estados. Como chama nossa atenção Guttmann:

Essa inovação, o chamado "mercado de eurodólares" deu origem a uma forma de moeda bancária simultaneamente privada e realmente apátrida, cuja emissão de circulação no interior de uma rede bancária mundial, escapavam ao espaço nacional controlado pelos bancos centrais. Por não terem de arcar com os custos ligados às regulamentações públicas, os depósitos e empréstimos em eurodólares podiam oferecer condições mais interessantes que seus equivalentes nacionais, que continuavam regulamentados. Com a diversificação do 
euromercado em outras moedas, no final da década de 1960, esse mercado tornou-se um vetor perfeito para a especulação monetária, o que, com o tempo, contribuiu para derrubar o sistema de Bretton Woods ${ }^{26}$.

O deslocamento dos fluxos financeiros para além dos limites nacionais já era um primeiro sinal da crise no sinal de que era uma busca por parte dos agentes envolvidos de fugir de situações de saturação que podiam levar-lhes à insolvência. No entanto, quando a saturação começou a se generalizar pelo sistema mundial criou-se um impasse: alguém tinha que pagar a conta. Segundo Guttmann (1998) até a década de 1970 os credores foram penalizados por não poderem aumentar os juros sobre seus empréstimos diante do aumento dos riscos de insolvência que vinham enfrentando (o que seria uma reação comum no âmbito do mercado de crédito), devido à política de "dinheiro fácil" praticada pelos bancos centrais, a qual mantinha o mercado de crédito gerido de acordo com os interesses do desenvolvimento. Esta política dos bancos centrais, no entanto, foi solapada por aquela rede internacional de fluxos financeiros que vinha se formando. Desta começaram a partir ataques especulativos ao dólar e outras moedas, obrigando o governo americano a suspender a conversibilidade entre o dólar e o ouro e, assim, intensificar o processo de desregulamentação que promoveu o salto da internacionalização financeira. A partir daí, os credores passaram a ter um forte papel na definição das políticas econômicas nacionais, o que significava o início de uma crescente eliminação daqueles elementos políticos presentes até então na gestão da moeda. Ou seja, iniciou-se uma tendência de retorno (nunca absoluto) da moeda à sua posição de simples medida da riqueza abstrata.

Este movimento é que pode ser entendido como o determinante fundamental das novas formas de territorialização que estou procurando identificar aqui como territorialização abstrata. Mas deve-se tomar cuidado o caráter abstrato desse processo não é marcado, como querem fazer crer os apologistas ou os deslumbrados, com "fenômenos" como a desmaterialização da riqueza ou o fim dos Estados nacionais. Ao contrário, ele se dá, isto sim, por meio de dois movimentos que formam um único processo: a integração financeira mundial. Esta é promovida de baixo pela abertura dos mercados financeiros nacionais e de cima pela tentativa de construir uma nova estrutura financeira global. Os estudos sobre ambos os movimentos têm de ser aprofundados, mas com o que já existe é possível fazer uma primeira avaliação.

\footnotetext{
${ }^{26}$ Guttmann, 1998, pág. 70.
} 


\section{5 - Abertura financeira, nova estrutura financeira global e territorialização abstrata.}

O processo de integração financeira global se dá por meio da consolidação de uma rede de fluxos financeiros em escala mundial. Este processo, no entanto, não pode ser visto simplesmente como uma maior troca de capitais entre os lugares. Afinal, esta rede não se forma espontaneamente e nem é marcada pela neutralidade que em geral se costuma associar às formas reticulares, quando vistas como simples suporte para a comunicação à distância. Ao contrário, se a hipótese aqui proposta for ao menos uma tendência, esta rede impõe coações aos territórios pelos quais ela se estende no sentido de pôr a riqueza abstrata como uma mediação dos processos de territorialização. A delimitação dos termos dessa hipótese é o que farei a seguir.

Para começar, é preciso definir a natureza dos fluxos que percorrem esta rede. Como demonstra Chesnais (1996) estes fluxos são marcados pela presença de novos agentes e pela criação de novos tipos de instrumentos. Os novos agentes são, primordialmente, os fundos de pensão que buscam oportunidades para fazer seu montante crescer. Mas o mais importante neste momento é entender os novos instrumentos. Para isso, consideremos o que nos diz Machado;

A tendência de desregulamentação do sistema financeiro foi acelerada na década de 1970, nessa ocasião liderada pelos Estados Unidos que, ao abolir as regras para a cobrança de comissões pelos negociantes de crédito, incentivou a competição entre bancos e operadores financeiros. Em conseqüência, estes foram levados a assumir maiores riscos e a inventar novas maneiras de criar e negociar créditos. Concomitante ao fim do acordo de Bretton Woods, a adoção de taxas de câmbio flutuantes em vez de fixas tornou os mercados financeiros mais especulativos. As incertezas do mercado criaram mecanismos de hedging, como o mercado de swaps, opções e futuros, que são essencialmente negociações de transferência de risco e, mais recentemente, a securitização, que significa a transformação dos ativos financeiros das empresas em instrumentos negociáveis no mercado ${ }^{27}$.

\footnotetext{
${ }^{27}$ Machado, 2002.
} 
Seguindo também o que afirma Freitas (1999), houve uma mudança na natureza do circuito financeiro no sentido dele se aproximar fortemente de um comércio de crédito e de dívidas. Os diversos tipos de instrumentos financeiros produzidos pelos bancos passam a adotar - numa interpretação um tanto livre e arriscada de minha parte - uma posição de mercadorias sendo negociadas os diversos agentes. Nesta posição o mais fundamental para que tais instrumentos sejam vendidos é a avaliação que deles fazem os diversos investidores envolvidos. As dívidas de governos, empresas, bancos e pessoas se concentram na forma de títulos negociáveis e passaram a ser avaliados em termos de riscos e possibilidades de rendimentos. Esta mudança exprime sinteticamente a grande transição que se dá a partir da década de 1970 com o ganho de poder por parte dos credores, o qual significou um retorno do dinheiro à condição de medida da riqueza abstrata em detrimento do seu caráter de bem público. Neste sentido, segundo Belluzzo,

A história do capitalismo é melhor contada através dos relatos que informam sobre as transformações sofridas pelo comércio do dinheiro e da riqueza. Nestes mercados se realiza o julgamento diário das formas particulares de riqueza capitalista - ações das empresas, títulos da dívida pública e privada - diante das leis implacáveis que guiam o veredicto irrecorrível do dinheiro, forma universal da riqueza ${ }^{28}$.

Este comentário nos leva à reflexão sobre as relações entre o circuito financeiro e o restante da economia capitalista (as formas particulares da riqueza). Em princípio, a riqueza no capitalismo é produzida por meio da extração do excedente que se dá no processo produtivo real. Se concordarmos com a possibilidade de que vem ocorrendo uma financeirização da economia nas últimas décadas, isso não deve significar que há uma produção de riqueza no âmbito financeiro, mas sim que a produção de riqueza, que se dá nos mesmos processos produtivos de sempre, passa a ser comandada pelo circuito financeiro. Neste sentido, algo que a priori parece um mero produto - as finanças - passa a ser um produtor de relações sociais. Esta produção se dá, principalmente, através de dois mecanismos: a taxa de juros e a necessidade de produzir confiabilidade.

Em relação à taxa de juros, é preciso entender que numa economia monetária da produção, os juros sobre o dinheiro acabam funcionando de modo a alterar todos os processos sociais que são mediados pela moeda. Afinal, como chama nossa atenção Belluzzo,

\footnotetext{
${ }^{28}$ Belluzzo, 1997, pág. 151.
} 
Os contratos de divida sempre mereceram uma atenção especial porque embora amparem o financiamento de ativos de rendimento incerto, obrigam a pagamentos certos e regulares, Isto corresponde à natureza contratual (relativa ao "capital propriedade") das dividas e pagamentos de juros ${ }^{29}$.

Ou seja, quando se dá uma relação entre um financiador e um financiado, principalmente em que este último aplicará a importância cedida pelo primeiro em atividades produtivas, independentemente destas atividades renderem ou não a riqueza esperada será preciso quitar o empréstimo. Isso significa que o financiado, sob risco que perder aquilo que tem, precisa de qualquer forma fazer com que os investimentos feitos com os empréstimos rendam aquilo que foi esperado. A partir daí podemos entender os problemas de se ter uma alta taxa de juros. Por um lado, ela leva muitos a não fazerem investimentos no setor produtivo devido ao aumento da possibilidade de insucesso no pagamento dos empréstimos. Por outro, como destaca Guttmann (1998), este aumento leva à necessidade de reestruturação no setor produtivo. Reestruturação, como se sabe significa todo o tipo de eliminação de elementos que possam atravancar a obtenção de altas taxas de lucro, isto é, eliminação de barreiras que impedem a posição do capital.

Neste sentido, o aumento dos juros que vem ocorrendo devido à reestruturação financeira global pode ser entendido como um movimento de acumulação primitiva no sentido de ser um elemento que não é propriamente capitalista - já que a cobrança de juros é um rentismo que o capitalismo herdou de épocas anteriores, vide $O$ Mercador de Veneza - mas que leva à eliminação de barreiras à abstração. Esta hipótese pode ganhar um contorno mais preciso se compararmos este processo com aquele apontado por Wood (2001) no conjunto de mudanças que gerou o capitalismo agrário inglês. Como uma referência sintética basta lembrar que, segundo a autora, foi a passagem da cobrança de renda em dinheiro pelo uso da terra que obrigou os camponeses arrendatários ingleses a adotarem a cultura do melhoramento, isto é, da busca constante pelo aumento da produtividade. Portanto, ao contrário do período anterior quando o uso do dinheiro atendia a parâmetros que não eram puramente econômicos, agora estes é que começam a predominar.

Mas a regulação do comércio de dívidas não se baseia apenas nos juros, ela está ligada também à exigência, por parte dos credores, da geração de confiabilidade.

\footnotetext{
${ }^{29}$ Belluzzo, 1997, pág. 157.
} 
Confiabilidade, é claro, no sentido de minimização dos riscos de insolvência. Para que isto se dê, todos os possíveis entraves à quitação das dívidas devem ser eliminados, não importando de que natureza eles sejam. Na verdade passa a ser necessário dar prioridade absoluta ao pagamento das dívidas para que se possa conseguir uma boa avaliação da parte dos investidores. Neste sentido, os devedores passam a ser dirigidos segundo os parâmetros definidos pelos credores. Mas pode-se perguntar qual a novidade disso. Afinal não é comum desde "sempre" que alguém para dispor de uma riqueza sua para o uso de outrem além de pedir por isso uma recompensa (os juros) peça também uma garantia? Sem dúvida.

A diferença, no entanto, é que na nova arquitetura do sistema financeiro mundial estas garantias vem se integrando ao esquema de comércio de dívidas, compondo parte do valor destas. Freitas (2001) demonstra claramente os problemas envolvidos nas negociações para se constituir tal arquitetura, iniciadas com o acordo da Basiléia de 1988, procuram estabelecer os parâmetros para atuação dos agentes que comercializam o dinheiro em âmbito global.

Basicamente, a questão de que trata a autora é a seguinte. Num mercado financeiro mundializado no qual milhares de agentes atuam comprando e vendendo dívidas uns dos outros, considerando que não há mais a garantia metálica do dinheiro como no padrão ouro e nem mesmo a conversibilidade do dólar ao ouro como existia durante a vigência de Bretton Woods, ou qualquer outra forma estável de se avaliar a garantia de cada dívida, como se estabelecer os padrões mínimos de segurança para tal sistema? Como se poderia saber se uma moeda, seja qual for sua forma, é ou não conversível?

Segundo as negociações mais recentes três pilares tendem a estruturar esta nova arquitetura: requerimento de capital mínimo, supervisão da adequação de capital e o fortalecimento da disciplina de mercado. Os dois primeiros pilares acabam reforçando a tendência à concentração no sistema financeiro internacional dando prioridade aos títulos emitidos por grandes bancos. Quanto ao terceiro, o que se busca é expor cada forma de dívida à avaliação dos mercados de dívidas. Essa avaliação é feita por empresas especializadas por meio de um conjunto de informações o maior possível, numa tentativa de se considerar todos, ou quase todos, os elementos que podem demonstrar se uma dívida é ou não conversível. Machado, no trecho a seguir descreve de forma precisa como se dá este processo; 
A “integração” do sistema financeiro é uma via de mão dupla, não só no que concerne às inovações financeiras como também às inovações tecnológicas na área da informática e das telecomunicações. Cada centro financeiro (lugar geográfico) é um nódulo e, ao mesmo tempo, um agregado de outros nódulos (banco, bolsas, agentes financeiro) de uma rede sustentada pelos meios de telecomunicação. Cada nódulo processa as informações disponíveis e atua em concordância a elas. Isso pode significar duas coisas: pode dar origem a "processos cooperativos", no sentido de que decisões são tomadas sem que cada nódulo detenha todas as informações (Huberman, 1990) mas a resultante aumenta a sinergia positiva do sistema, na medida que a comunicação entre cada nódulo pode manter o sistema em "estado estável" (o princípio teórico subjacente é o de que quanto maior a comunicação dentro do sistema maior será a proporção de flutuações (perturbações) insignificantes, ou seja, maior será a sua estabilidade). Inversamente, a precariedade da informação e a exigência estrutural de rapidez na tomada de decisão pode resultar numa sinergia negativa, no sentido de que informações incompletas rapidamente se espalham pelo sistema, a pequena flutuação que representa a ação de cada nódulo sendo ampliada, o que coloca em risco o "estado estável" do sistema. De fato, a operação em rede do sistema financeiro, permite não só a transmissão de informação de maneira cada vez mais rápida e mais barata como permite maior facilidade de acesso à diferentes mercados geograficamente dispersos ${ }^{30}$.

Considerando que todas as formas de títulos negociados no mercado financeiro internacional se referem, em última instância, a processos reais de produção de riqueza, sua conversibilidade depende, justamente, do sucesso desta produção. Mas se no capitalismo há uma intermediação das condições de mercado entre a produção e a realização da riqueza, a conversibilidade depende de tais condições. Neste sentido, ao que parece, a pretensão desta arquitetura do mercado financeiro mundial é ser uma espécie de concreção da abstração promovida pela própria relação-capital.

Se juntarmos estas duas questões - a dos juros e a da avaliação dos riscos - ao processo de abertura que expôs os mercados financeiros nacionais a esta nova dinâmica dos mercados financeiros globalizados e, ainda, considerarmos que numa economia capitalista as relações são perpassadas pela medida da riqueza abstrata, poderíamos

\footnotetext{
${ }^{30}$ Machado 2002.
} 
vislumbrar uma crescente intermediação dos processos de territorialização - desde investimentos na agricultura até a incorporação de projetos imobiliários, passando por todos os investimentos estatais e industriais - pelos padrões do mercado financeiro internacionalizado - ao que poderíamos entender como territorialização abstrata.

A abstração neste caso deve ser entendida como a posição do capital enquanto riqueza abstrata que media as relações sociais. Esta posição, no entanto, não é automática, sendo, ao contrário resultado de um processo não econômico que a vem garantindo. Neste sentido, vêm colaborando, em primeiro lugar, as pressões de órgãos internacionais que impõem regras aos países que queiram deles participar ao mesmo tempo em que impõem restrições àqueles que não se integram. O Fundo Monetário Internacional e a Organização Mundial do Comércio estão entre os principais. Poderia-se refletir sobre uma continuidade do caráter estatista (regulacionista) isento dos compromissos territorialistas que talvez caracterizem tais instituições. Mas, em segundo lugar, este processo de acumulação primitiva via financeirização da economia mundial poderia ser identificado com algo como um "cercamento do dinheiro". Afinal, o que ocorre é que se dá uma hierarquização na mundialização financeira, como aparece no seguinte trecho de Oliveira;

\begin{abstract}
O tamanho da divida externa norte-americana é a expressão dessa mundialização, vale dizer, o dólar norte-americano é o financiamento da acumulação de capital em escala mundial e seu resultado, ao mesmo tempo que a economia norte americana não pode expandir-se sem o concurso das reservas mundiais aplicadas nos títulos do Tesouro norteamericano. As dívidas externas da periferia querem dizer a mesma coisa: no caso do Brasil, por exemplo, sua dívida externa quer dizer que a reprodução ampliada do capital não se dá a não ser na forma dinheiro-dólar ${ }^{31}$.
\end{abstract}

Ou seja, a conversibilidade das dívidas e do dinheiro de cada país tem que passar necessariamente pelo dólar americano (pelo menos de forma prioritária pelo dólar) e, para isso é preciso aceitar as taxas de juros e as condicionalidades de uso deste que é o único dinheiro mundial. Essa estrutura lembra bastante aquela do arrendamento das terras colocada por Wood, com a diferença de que não estão, os produtores e os investidores do mercado financeiro, todos no mesmo território. Isso significa, em primeiro lugar, que o aumento de produtividade, ou melhoramento, que se dê num território não necessariamente

\footnotetext{
${ }^{31}$ Oliveira, 2004, pág. 193.
} 
se realiza neste território e, em segundo, que não há, pelo menos não ainda de forma clara, a possibilidade de promover revoltas mundiais que obriguem os detentores do dinheiro a aceitarem como mediação para sua riqueza outros elementos que não os da pura acumulação de riqueza abstrata. 


\section{Considerações finais}

Abstração em termos de conhecimento significa retirar da realidade um elemento que a ela pertence e que nela está misturado a todos os outros. Abstrair, neste sentido, significa separar, isolar, algo de seu contexto original. O objetivo deste isolamento é a possibilidade do conhecimento. Etapas fundamentais para a constituição do conhecimento, como a nomeação por exemplo, dependem desse passa, é preciso separar para conhecer.

Esta separação, no entanto, não significa, necessariamente, um isolamento absoluto e permanente. $\mathrm{O}$ ideal é que ele não seja. $\mathrm{O}$ ideal é que exista um retorno constante daquilo que foi separado ao seu contexto original, isto tanto porque cada separação que nosso aparato cognitivo promove não é per-feita (acabada) como porque é preciso voltar à realidade no sentido de completar o sentido da transformação do mundo por meio do conhecimento.

No caso da abstração própria ao capital, o sentido é outro. Apesar de também encontrarmos aí um movimento de isolamento este se refere a um isolamento efetivo de elementos da realidade que não colaborem diretamente para com o objetivo préestabelecido segundo os padrões da valorização do valor. É neste sentido que a abstração do capital tende a eliminar barreiras e, ao mesmo tempo, se realiza por meio da eliminação de tais barreiras. Estas barreiras eliminadas pela posição do capital são aquelas que impediam-no de se realizar, aquelas que impedem constantemente o processo de abstração pelo qual um elemento é isolado da realidade complexa à qual pertence. Mas é justamente esta realidade complexa que exige, para que se produza a abstração do capital, a geração de outras tantas barreiras.

É neste sentido que se dá exacerbação do privado em detrimento do público. O público pode estar ligado ás relações comunitárias, numa perspectiva mais tradicional, ou à esfera pública característica do Estado moderno, claro, numa perspectiva menos tradicional. Mas de uma maneira outra, o público procura abarcar algum nível de complexidade social que, de qualquer forma é mais amplo que o âmbito provado.

Este último, por sua vez, funda-se na abstração. A opção pelo privado reafirma a fragmentação, entendo que privadamente é possível se resolver os problemas que afligem 
cada um em sua vida. O problema dessa opção é que ela corrobora com a abstração, com a desconsideração de elementos que realmente existem e que vez ou outra impõe sua existência.

Nas semanas que finalizei este trabalho, os "atentados" do Primeiro Comando da Capital aterrorizaram grande parte da classe média brasileira, principalmente paulista. Apresentadores de TV e outros tantos representantes da "opinião pública" nacional pediram mais rigor nas prisões e nas ruas. Afinal, entenderam que a segregação que se promove no Brasil é fraca demais. Ilusão.

$\mathrm{O}$ que poucos perceberam foi que aquilo era, justamente, uma crise. Uma extrapolação das contradições que marcam o modelo excludente de sociedade que temos. Segundo dados dos jornais o número de presidiários a cada 100 mil habitantes triplicou no Estado de São Paulo ao longo dos vintes e um anos que se passaram do fim da ditadura militar. O número de shopping centers já passa de 600 no território nacional e a moda dos investimentos turísticos são os Resorts dentro dos quais os turistas podem aproveitar, isolados, suas férias. Há segregação de um lado e do outro e toda ela está diretamente ligada ao processo de territorialização abstrata.

Quando se põe, porque a sociedade permite que se ponha, a valorização da riqueza abstrata como norma soberana e inquestionável de reprodução não há como se evitar esta fragmentação. O filtro da valorização impõe que se deixem de lado todos aqueles conteúdos que lhe são exteriores, que lhe servem como obstáculo. A territorialização acontece mesmo assim, ela tem de acontecer de qualquer forma. Mas ela é seletiva e daí seu caráter de redes territoriais. Se estas redes, no entanto, questionam o poder do Estado por cima, em direção ao internacional, elas também o fazem como redes intraterritoriais. Nas revoltas do PCC existiam mais de 70 presídios amotinados. Presídios que, a priori, deveriam estar isolados, mas que por meio da comunicação efetivada por um dos instrumentos que melhor simboliza a exacerbação do individualismo - o celular conseguiram formar uma rede que comandou o "caos" fora dela. As pessoas de fora dessa rede correram para outras redes, a dos condomínios, dos telefones e da Internet.

Esta é, sem dúvida, uma crise manifesta. 


\section{BIBLIOGRAFIA}

ANDERSON, Perry. "Balanço do neoliberalismo". In SADER, Emir; Gentilli, Pablo (org) Para além do neoliberalismo. Rio de Janeiro: Paz e Terra, 1995.

ANTAS Jr., Ricardo Mendes. "Elementos para uma discussão epistemológica sobre a regulação do território”. In Revista GeoUSP, nº16, 2004.

ARRIGHI, Giovanni. $O$ Longo Século $X X$. São Paulo: Unesp; Rio de Janeiro:

Contraponto, 1996.

. "Globalização e macrosociologia histórica.” In Revista de Sociologia e

Política $n^{\circ}$ 20, UFPR, Curitiba, jun 2003.

ARANTES, Paulo Eduardo. “Cavalaria Global”. In Revista Margem Esquerda nº 04. São Paulo: Boitempo, 2004. . "Último round". In Revista margem Esquerda nº 05. São Paulo: Boitempo, 2005.

BELLUZZO, Luiz G.M.. Valor e Capitalismo. São Paulo: Bienal, 1987. "Dinheiro e as transfigurações da riqueza". In TAVARES, Maria da C.; FIORI, José, L. Poder e Dinheiro: uma economia política da Globalização. Petrópolis: Vozes, 1998.

BENSAÏD, Daniel. Cambiar el Mundo. Madrid: Catarata, 2004.

BRAUDEL, Fernand. A dinâmica do capitalismo. Lisboa: Teorema, 1989.

BRENNER, Robert. O boom e a bolha. Rio de Janeiro: Record, 2003.

CARLOS, Ana Fani Alessandri. O lugar no/do mundo. São Paulo: Hucitec, 1996. . “Novas’ contradições do espaço”. In CARLOS, Ana Fani Alessandri \& DAMIANI, Amélia Luisa \& SEABRA, Odette C. Lima. O Espaço no fim de século: a nova raridade. São Paulo: Contexto, 1999.

. "São Paulo hoje: as contradições no processo de reprodução do espaço". In Scripta Nova Revista Eletrônica de Geografia y ciencias sociales: Barcelona: Universidad de Barcelona, $\mathrm{N}^{\mathrm{o}} 88,1$ de mayo de 2001.

CARNEIRO, Ricardo. “Globalização Financeira e Inserção periférica”. In Revista Economia e Sociedade n¹3, Instituto de Economia - Unicamp; Campinas, 1999.

CHESNAIS, François. A mundialização do capital. São Paulo: Xamã, 1996. 
CICCOLELLA. Pablo José. "Hacia um capitalismo sin fronteras? O la historia recien comienza". In ESCOLAR, Marcelo; MORAES, Antônio C. Robert. (Org). Nuevos Roles Del Estado em el reordenamiento Del território: aportes teóricos. Buenos Aires: UBA, 1998.

DAMIANI, Amélia Luisa. “As contradições do espaço: da lógica (formal) à (lógica) dialética, a propósito do espaço". In CARLOS, Ana Fani Alessandri \& DAMIANI, Amélia Luisa \& SEABRA, Odette C. Lima. O Espaço no fim de século: a nova raridade. São Paulo: Contexto, 1999.

"A propósito do espaço e do urbano: algumas hipóteses". In Revista Cidades, volume 1, número 1, Janeiro-Junho 2004.

DE ANGELIS, Massimo. "Marx and primitive accumulation: the continuous character of capital's 'enclosures"' in The Commoner, $\mathrm{n}^{\circ} 2$, September 2001. (pode ser encontrado no endereço: www.commoner.org.uk/02deangelis.pdf)

DEBORD, Guy. A Sociedade do Espetáculo. São Paulo: Contraponto, 1997.

DUPAS, Gilberto. Tensões contemporâneas entre o público e o privado. Rio de Janeiro: Paz e Terra, 2003.

FAUSTO, Ruy. Marx, Lógica e Política vol. I. São Paulo: Brasiliense, 1987, $2^{a}$ edição. FERNANDES, Bernardo Mançano. "Movimentos socioterritoriais e socioespaciais. Contribuição teórica para uma leitura geográfica dos movimentos sociais”. In (http://osal.clacso.org/espanol/html/documentos/Fernandez.doc) 2005.

FILGUEIRAS, Luiz. História do Plano Real. São Paulo; Boitempo, 2000.

FIORI, José Luis. $O$ Vôo da coruja. Para Reler o desenvolvimentismo brasileiro. Rio de Janeiro: Record, 2003. 60 lições dos 90. Uma década de neoliberalismo. Rio de Janeiro: Record, 2001. . "De volta à questão da riqueza de algumas nações" In FIORI, José Luis (org.). Estados e moedas no desenvolvimento das nações. Petrópolis: Vozes, 2000. . "Estados, Moedas, desenvolvimento". In FIORI, José Luis (org.). Estados e moedas no desenvolvimento das nações. Petrópolis: Vozes, 2000 a. 
. “Globalização, Hegemonia e Império". In TAVARES, Maria da C.; FIORI,

José, L. Poder e Dinheiro: uma economia política da Globalização. Petrópolis: Vozes, 1998.

FREITAS, Maria Cristina Penido de (org). Abertura do sistema financeiro no Brasil nos anos 90. São Paulo: Fundap: Fapesp; Brasília; Ipea, 1999.

FREITAS, Maria Cristina Penido de; PRATES, Daniela Magalhães. "Sistema

Financeiro e Desenvolvimento: as restrições das novas regras do Comitê da Basiléia sobre os países periféricos". In Seminário Don Raul Prebisch

(www.ie.ufrj.br/prebisch/index.html), 2001.

GERMER, Claus M. "Fundamentos teóricos da análise marxista do sistema monetário internacional". In (http://www.gre.ac.uk/ fa03/iwgvt/files/00germer.rtf), 2000.

GOMES, Marcio Fernando. "O caminho para revelar a territorialidade das instituições financeiras". In Anais do I SEPEGE: Pesquisa em Geografia no Século XXI, DG-FFLCHUSP, 2003.

GONÇALVES, Reinaldo. Globalização e Desnacionalização. Rio de Janeiro: Paz e Terra, 1999.

GUTTMANN, Robert. “As mutações do capital financeiro”. In CHESNAIS, François (org). A mundialização financeira. São Paulo: Xamã, 1999.

GRESPAN, Jorge Luis. O Negativo do Capital. São Paulo: Hucitec: FAPESP, 1998. - "A crise na crítica à economia política" in Vários Autores. A obra teórica de Marx: atualidade, problemas e interpretações. São Paulo: Xamã, 2000. . "Capital e crise: os desafios da teoria" in Revista Margem Esquerda n ${ }^{\circ}$ 4. São Paulo: Boitempo, 2004.

HABERMAS, Jürgen. "Entre ciencia y filosofia: el marxismo como critica”. In Teoría y práxis. Madrid: Tecnos, 2000.

HAESBAERT. Rogério. "Da desterritorialização à multiterritorialidade". In Anais do X Encontro de Geógrafos da América Latina. USP, 2005.

HARVEY, David. O novo imperialismo. São Paulo: Edições Loyola, 2004 . A condição pós-moderna. São Paulo: Loyola, 1992. . Los límites del capitalismo e la teoría marxista. Cidade do México: Fondo de Cultura Económica, 1990. 
. 'O ‘novo' imperialismo: sobre arranjos espaciotemporais e acumulação por despossessão". In Revista Margem Esquerda n 05. São Paulo: Boitempo editorial, 2004.

HEGEL, Georg W. Friedrich. A Razão na História. Lisboa: Edições 70, 1995.

HEIDRICH, Álvaro Luiz. “Fundamentos da Formação do Território Moderno”. In http://www.ilea.ufrgs.br/nerint/arquivoartigos/content523/content523_2/FUNDAMENTOS $\underline{. h t m l}$.

HOLLOWAY, John. Mudar o mundo sem tomar o poder. São Paulo: Viramundo, 2003.

HOBSBAMW, Eric. Era dos extremos. São Paulo: Companhia das Letras, 1996.

JAMESON, Fredric. "Cultura e capital financeiro". In . A cultura do dinheiro. Petrópolis: Vozes, 2001.

KOSELLECK, Reinhart. Crítica e Crise. Rio de Janeiro: Eduerj: Contraponto, 1999.

KURZ, Robert. “A falta de autonomia do Estado e os limites da política” in: KURZ, Robert. Os Últimos combates. Petrópolis: Vozes, 1997a.

. "Para além de Estado e Mercado" in: KURZ, Robert. Os Últimos combates. Petrópolis: Vozes, 1997b.

. "A virtualização da economia - mercados financeiros transnacionais e a crise da regulação". Folha de São Paulo, 23 de maio de 1999.

. "A ascensão do dinheiro aos céus" (http://obeco.planetaclix.pt/ rkurz101.htm), 2002.

LEFEBVRE, Henri. O direito à cidade. São Paulo: Editora Moraes, 1991. . A revolução urbana. Belo Horizonte: Editora UFMG, 1999. . A respeito do Estado. Tradução para o Português do Del' Etat. GESP (Grupo de Estudos São Paulo) - Laboratório de Geografia Urbana - FFLCH/USP, 2004, mimeo. . A produção do Espaço. Tradução Laboratório de Geografia Urbana... O fim da história. Lisboa: Dom Quixote, 1971. . A re-produção das relações sociais de produção. Lisboa: Escorpião, 1978.

MACHADO, Lia Osório. "Sistemas, Fronteiras e Territórios”. In (www.igeo.ufrj.br/ fronteiraspesquisa/fronteira/p02avulsos01.htm). 2003. . “Limites, Fronteiras, Redes”. In Vários Autores. Fronteira e Espaço Global. Porto Alegre: AGB-Porto Alegre, 1998. 
. "Comércio ilícito de drogas e a geografia da integração financeira: uma

simbiose?” In http://www.igeo.ufrj.br/gruporetis/pesquisa/droga/p01pub02.htm. 2002.

MARTINS, José de Souza. “As temporalidades da história na dialética de Lefebvre”. In . (org.) Henri Lefebvre e o retorno à dialética. São Paulo: Hucitec, 1996.

MARTINS, Sérgio. "Crítica à economia política do espaço". In CARLOS, Ana Fani Alessandri \& DAMIANI, Amélia Luisa \& SEABRA, Odette C. Lima. O Espaço no fim de século: a nova raridade. São Paulo: Contexto, 1999.

MARX, Karl. O Capital. Crítica da economia política. São Paulo: Nova Cultural, 1988. . Capítulo VI inédito de O Capital. São Paulo: Editora Moraes, 1985. . "Introdução à Crítica da Filosofia do Direito de Hegel” in Crítica da Filosofia do Direito de Hegel. São Paulo: Boitempo, 2005.

MATOS, Carlos A. de. "Globalizacion, movimentos del capital, mercados de trabajo y concentracion territorial expandida". In Vários Autores. Fronteiras na América Latina. Espaços em transformação. Editora da Universidade.

MORAES, Antonio Carlos Robert. Bases da Formação territorial do Brasil. São Paulo; Hucitec, 2000.

NOVY, Andréas. A des-ordem na periferia: 500 anos de espaço e poder no Brasil. Petrópolis, RJ: Vozes, 2002.

OLIVERIA, Ariovaldo Umbelino de. "Espaço e tempo: compreensão materialista e dialética”. In: Santos, Milton (org). Novos rumos da Geografia brasileira. São Paulo: Hucitec, 1982.

OLIVEIRA, Francisco. A economia da dependência imperfeita. Rio de Janeiro: Graal, 1989. . Crítica à razão dualista e O ornitorrinco. São Paulo: Boitempo, 2003. . Os direitos do antivalor. Petrópolis: Vozes, 1998. . "Os sentidos do capital pós-Bretton Woods". In Revista Margem Esquerda n 04. São Paulo: Boitempo, 2004.

PAULANI, Leda Maria. "A atualidade da crítica da economia política”. In Vários Autores. A obra teórica de Marx: atualidade, problemas e interpretações. São Paulo: Xamã, 2000. 

. "Sobre dinheiro e valor; uma crítica às posições de Brunhoff e Mollo". In Revista de Economia Política, vol.14, no 3 (55), julho-setembro / 1994.

. "Brasil delivery: razões, contradições e limites da política econômica nos primeiros seis meses do governo Lula". (www.lppuerj.net/outrobrasil/Referencias_Destaque.asp?Id_Sub_Referencia=8), 2003.

ROSDOLSKY, Roman. Gênese e Estrutura de O Capital de Karl Marx. Rio de Janeiro: Eduerj: Contraponto, 2001.

SANTOS, César Ricardo Simoni. "Brasília: do tempo ao espaço e a constituição de uma hegemonia estatista". In Anais do X Encontro de Geógrafos da América Latina. USP, 2005.

SANTOS, Milton; SILVEIRA, Maria Laura. O Brasil: Território e sociedade no início do século XXI. Rio de Janeiro: Record, 2001.

SMITH, Neil. Desenvolvimento Desigual. Rio de Janeiro: Bertrand Brasil, 1988.

SPOSITO, Eliseu Savério. “A noção de território. Uma leitura pela noção de desenvolvimento". In Anais do X Encontro de Geógrafos da América Latina. USP, 2005. SPOSITO, Eliseu Savério \& SANTOS, Leandro Bruno dos. "A globalização e suas facetas; grupos econômicos globais e territórios locais na aurora do século XXI". In Anais do X Encontro de Geógrafos da América Latina. USP, 2005.

VELTZ, Pierre. Mundialización, Ciudades y Territórios. Barcelona: Editorial Ariel, 1999. . "Hierarquias e redes". In BENKO, Georges; LIPIETZ, Alain. Regiões Ganhadoras. Oeiras (PT): Celta, 1994.

WALLERSTEIN, Immanuel. Capitalismo Histórico e Civilização Capitalista. Rio de Janeiro; Contraponto, 2001.

WOOD, Ellen Meiksins. A Origem do Capitalismo. Rio de Janeiro: Jorge Zahar, 2001. . Democracia contra Capitalismo. São Paulo: Boitempo, 2003. 